Marina Granado e Sá

Efeitos do cobre na homeostase do caranguejo de mangue Ucides cordatus (Decapoda:

Ucididae)

Copper effects in homeostasis of mangrove crab Ucides cordatus (Decapoda: Ucididae)

São Paulo 
Marina Granado e Sá

\title{
Efeitos do cobre na homeostase do caranguejo de mangue Ucides cordatus (Decapoda: Ucididae)
}

\section{Copper effects in homeostasis of mangrove crab Ucides cordatus (Decapoda: Ucididae)}

\begin{abstract}
Versão corrigida da Tese apresentada ao Instituto de Biociências da Universidade de São Paulo, para obtenção do Título de Doutor em Ciências, na Área de Fisiologia Geral.
\end{abstract}

A versão original da tese encontra-se disponível no Instituto de Biociências da USP.

Orientador: Prof. Drō José Eduardo

Pereira Wilken Bicudo

São Paulo 
Sá, Marina Granado e

Efeitos do cobre na homeostase do caranguejo de mangue

Ucides cordatus, $231 \mathrm{p}$.

Tese (Doutorado) - Instituto de Biociências da Universidade de São

Paulo. Departamento de Fisiologia Geral.

1. Cobre 2. Ucides cordatus 3. Homeostase

Comissão Julgadora:

Prof. Dr.

Prof. Dr.

Prof. Dr.

Prof. Dr.

Prof. Dro José E.P.W. Bicudo

Orientador 
Aos meus pais Edélcio e Telma, irmãos Felipe e Gabriel e meu marido Regis.

Com todo meu amor... 
"Mesmo quando tudo parece desabar, cabe a mim decidir entre rir ou chorar, ir ou ficar, desistir ou lutar; porque descobri, no caminho incerto da vida, que o mais importante é o decidir" 


\section{AGRADECIMENTOS}

- Ao prof. Dro José Eduardo Pereira Wilken Bicudo, pelo aceite da orientação, confiança em meu trabalho e pela oportunidade de aprender cada vez mais. Obrigada pela paciência e compreensão;

- Ao Instituto de Biociências (IB-USP), por possibilitar o encontro com docentes que muito contribuíram para este processo tão longo (desde a iniciação científica) e com colegas que tanto trocamos ideias e partilhamos dúvidas, bem como a todos os funcionários do Instituto de Biociências que sempre estiveram dispostos a ajudar;

- À Universidade Presbiteriana Mackenzie por possibilitar o desenvolvimento de toda a parte experimental em suas dependências;

- Ao CNPq pelo apoio financeiro através do processo 142326/2009-7;

- Ao Profo Dro José Guilherme Chauí Berlik, coordenador de Pós Graduação por instruir, orientar e ouvir os alunos sempre que necessário;

- Aos amigos Tiago Gabriel e Vanessa Oliveira que estiveram sempre ao meu lado. Obrigada pelas nossas conversas, que de uma maneira ou outra nos ajudava a compreender e encontrar as soluções para nossos problemas, além, claro, da ajuda nos momentos de desespero;

- Aos meus pais, que se não acreditassem na minha profissão, nada teria acontecido. Obrigada por tudo;

- Aos meus irmãos, que perto ou longe, participaram de tudo;

- Aos meus avós, Anna e Waldemar, Senhorinha (in memmoriam) e Walter (in memmoriam) pelas palavras sábias em momentos de anseio, medo e alegrias, além de me ensinar a passar pelas adversidades da vida;

- Ao Regis, pela compreensão, amizade, apoio, amor e participação nos momentos mais importantes da minha vida. Sem tudo isso, seria muito mais difícil; 


\section{INDICE GERAL}

INTRODUÇÃO GERAL 8

CAPÍTULO 1 - Efeito do cobre na osmorregulação do caranguejo de mangue Ucides cordatus 37

CAPÍTULO 2 - Transporte de cobre em células epiteliais de brânquias e hepatopâncreas do caranguejo de mangue Ucides cordatus 61 CAPÍTULO 3 - Efeito do cobre no metabolismo energético do caranguejo de mangue Ucides cordatus 123 CAPÍTULO 4 - Efeito do cobre no estresse oxidativo do caranguejo de mangue Ucides cordatus 161

Considerações Finais 190

RESUMO GERAL 201

ABSTRACT 202

REFERÊNCIAS BIBLIOGRÁFICAS 203 
INTRODUÇAO GERAL 


\section{INDICE}

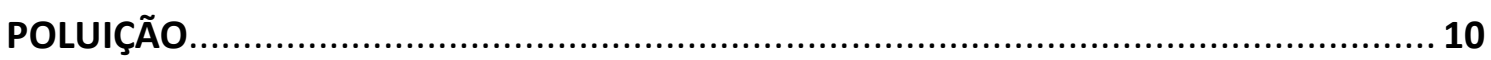

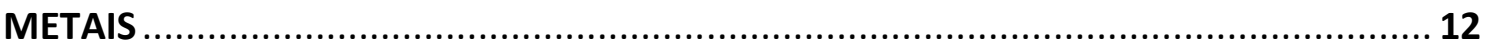

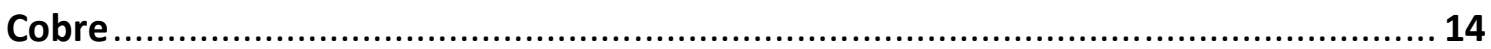

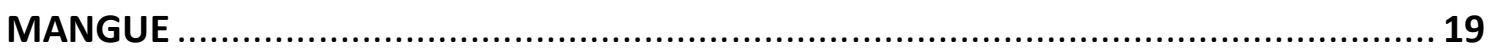

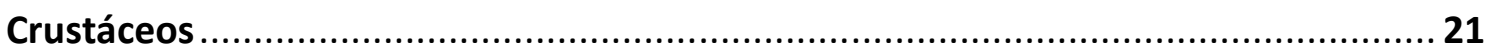

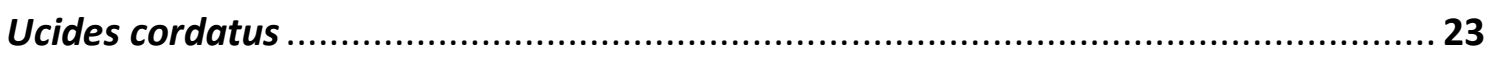

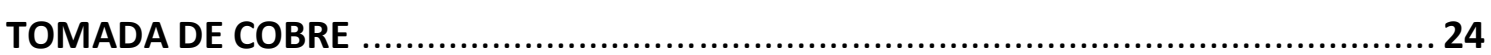

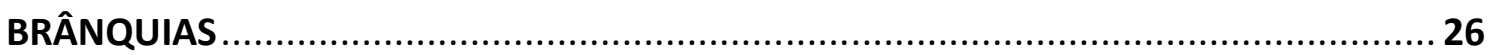

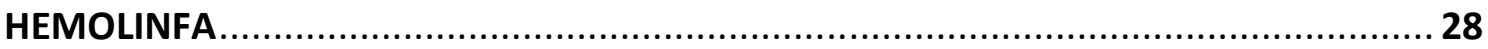

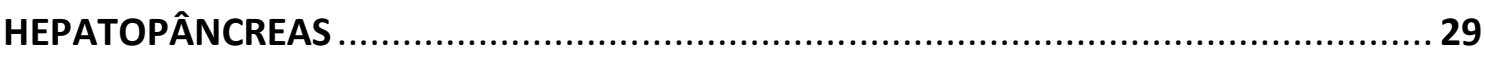

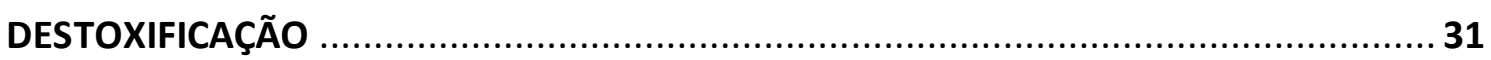

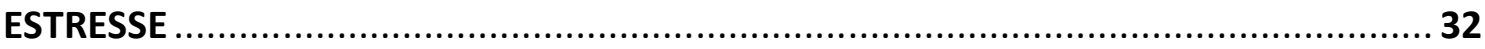

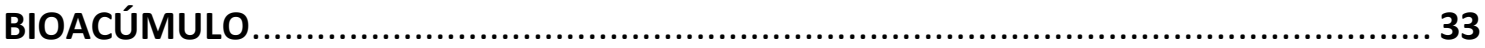

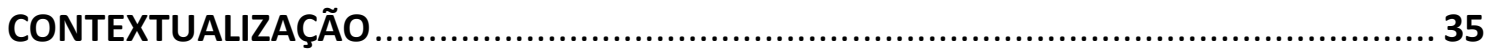




\section{POLUIÇÃO}

Recentemente, tem sido reconhecido que a água pode ser ao mesmo tempo uma fonte vital para os organismos e um veículo para eliminação de poluentes. Esse paradoxo pode ser considerado como parte da crise do presente ambiente que está inserida no conflito entre natureza e tecnologia. Este paradigma é acompanhado pelo emprego de biomarcadores, que consistem em indicadores bioquímicos e celulares da presença de contaminantes através da análise de fluidos corpóreos bem como células ou tecidos, e atualmente parâmetros comportamentais têm sido reconhecidos por estabelecer interferências ecológicas juntamente com observações bioquímicas e/ou fisiológicas (KRUGGER, 2001; MONSERRAT e col., 2006; ZAGATTO \& BERTOLETTI, 2006).

Muitas áreas estuarinas e costeiras em desenvolvimento são objeto de despejo de metais pelo homem e o acúmulo destes, especificamente ou não essenciais, é muito dependente da concentração ambiental na água e o período ao qual os animais são expostos a essas concentrações, além de existir também outros fatores que afetam processos de acúmulo, como temperatura e salinidade (CANLI \& FURNESS, 1993). Nas últimas décadas, entretanto, em decorrência dos processos de urbanização e de industrialização, quantidades consideráveis de metais são introduzidas nos sistemas aquáticos. A poluição por cobre advém do sulfato de cobre $\left(\mathrm{CuSO}_{4}\right)$, o qual é utilizado extensivamente como algicida na aquacultura de crustáceos (YANG e col., 2007). Este é somente um exemplo, pois o sulfato de cobre também é empregado em outras situações, como por exemplo, galvanização, manufatura de tintas e peças de mandeira (BURY e col., 2003), dentre outras.

A porção costeira do mar está frequentemente contaminada por diversos tipos de poluentes e patógenos humanos devido à atividade humana (CHUA, 1992; PAEZ-OSUNA \& TRON-MAYER, 1996; WU \& CHEN, 2005), e a mineração é considerada uma das mais importantes fontes antropogênicas de metais, juntamente com a queima de combustível fóssil, incineração, processo e produção de substâncias químicas. Além disso, o despejo industrial e atividades como extração de metal, representam contínua ameaça para o ambiente aquático (MARTÍN-DÍAZ e col., 2005).

A vida aquática está constantemente exposta à contaminação química devido ao aumento da variedade de atividades antropogênicas que podem induzir diversos mecanismos de toxicidade, cada um contribuindo para a variação dos estágios que levam à efeitos deletérios , podendo ao final, serem potencializados (WU \& CHEN, 2004; BORKOVIĆ e col., 
2008). Muitos destes componentes perigosos tais como os metais, podem ser acumulados em tecidos de crustáceos em concentrações mais elevadas que aquelas encontradas na coluna d'água e sedimento (RAINBOW, 2007), e, por isso, tanto os metais essenciais quanto os não essenciais podem se tornar tóxicos (BELTRAME e col., 2011).

Problemas de poluição são comuns na costa do Atlântico, onde há constante despejo de metais, nutrientes e compostos orgânicos, e em diversos sistemas os efeitos diretos e indiretos de poluentes têm causado impactos ambientais e econômicos, os quais incluem o acúmulo de contaminantes na biota, causando considerável aumento de anomalias de reprodução e desenvolvimento relacionadas com a poluição. Além de tais efeitos, foram observadas alterações nas condições físicas, fisiológicas e bioquímicas de peixes e invertebrados em geral (O'CONNOR \& HUGGETT, 1988). Como resultado da poluição através da introdução antropogênica direta e indireta de moléculas, surgem efeitos deletérios para fontes de habitat e até para a saúde humana (MONSERRAT e col., 2006).

Poluentes como os metais acumulados em sedimentos atingidos por esgotos podem ser prejudiciais para invertebrados bênticos expostos e podem ser carreados através da dieta, aos seres humanos, por exemplo, já que estes consomem frutos-do-mar. Tais contaminantes podem causar alterações dos processos biogeoquímicos e fisiológicos de organismos na base da cadeia alimentar, os quais podem ser quantificados por parâmetros biológicos estimados (frequentemente reportados como índices de estresse ou biomarcadores), cujas variações podem ser relacionadas com o status fisiológico dos animais ( O'CONNOR \& HUGGETT, 1988); VIARENGO e col., 1997).

Diversos estudos têm demonstrado a capacidade de organismos bênticos, próximos a esgotos, em acumular metais. Particularmente, as lagostas são conhecidas por acumular altas concentrações de metais oriundos do ambiente, principalmente no hepatopâncreas (glândula digestiva) (MORALES-HERNANDEZ e col., 2004). Muitos contaminantes ambientais não somente entram através das brânquias, mas também exercem efeitos tóxicos primários no epitélio branquial devido à interferência em um ou mais processos fisiológicos essenciais (WOOD, 1992) dos animais. 


\section{Metais}

Metais de transição como cobre $(\mathrm{Cu})$, zinco $(\mathrm{Zn})$, ferro $(\mathrm{Fe})$, cobalto $(\mathrm{Co})$, selênio $(\mathrm{Se})$ e manganês $(\mathrm{Mn})$ são essenciais para a saúde da maioria dos organismos, já que são partes integrantes de proteínas envolvidas em todas as funções biológicas. Sua onipresença é "governada" pela habilidade em formar uma gama grande de coordenadas geométricas e estados redox, os quais permitem a esses elementos interações com muitos componentes celulares, atuando amplamente na respiração celular, transporte de oxigênio, estabilidade proteica, "limpeza" de radicais livres e ação de diversas enzimas celulares, bem como a transcrição de DNA. No entanto, em excesso podem ser tóxicos, ligando-se inapropriadamente a moléculas sensíveis, ou formando perigosos radicais livres. E em consequência a esta particularidade, há um fino balanço entre a deficiência do metal e seu excesso e isso é vital para que os organismos mantenham a homeostase do metal através do balanço entre absorção e excreção (BURY, 2003).

Metais traço, incluindo aqueles definidos como metais pesados, provenientes de atividades industriais e mineradoras são descartados nas águas costeiras e estuarinas em diversos locais. Aqueles derivados da atividade antropogênica podem acumular em sedimentos locais (até 5 vezes mais do que na água) e os invertebrados que habitam tais sedimentos estão potencialmente expostos a concentrações de metais bastante elevadas (HARRIS \& SANTOS, 2000). As rotas de tomada - com destino aos tecidos - desses crustáceos podem ser através de fontes dissolvidas ou do alimento, e a proporção de acúmulo varia de acordo com as espécies, já que baixas concentrações de metal são encontradas em ambientes que apresentam condições "limpas" ou não poluídas. Além disso, as concentrações no corpo como um todo ou nos tecidos podem variar, dependendo das rotas de excreção e os mecanismos de desentoxicação de cada organismo (HARRIS \& SANTOS, 2000).

No que diz respeito ao aporte de metais em corpos aquáticos, sabe-se que eles são naturalmente incorporados aos sistemas por meio de processos geoquímicos. Fontes naturais de metais em corpos aquáticos incluem o desgaste de rochas e de solos devido ao intemperismo, assim como a ação direta dos corpos aquáticos sobre os mesmos. A deposição atmosférica, através das precipitações úmida e seca, também constitui uma importante fonte natural de metais (ALCORLO e col., 2006; SINGH e cols., 2007).

Os metais são a principal fonte de poluição nas águas naturais devido ao despejo de dejetos industriais, os quais são consideravelmente tóxicos para os organismos aquáticos 
(SINGH e cols., 2007). Rio abaixo das minas de minério, a concentração de metais na coluna d'agua tende a diminuir exponencialmente devido à adsorção de partículas, precipitação, sedimentação e diluição (O'CONNOR \& HUGGETT, 1988; ALCORLO e col., 2006).

Metais contaminantes estão continuadamente presentes no ambiente marinho podendo acumular e persistir no ambiente. Os metais estão entre os fatores mais intensivamente estudados contaminantes no ambiente de estuário e marinho (MACKEN e col., 2009). Os metais não podem ser destruídos por processos biológicos, como a degradação, e apresentam habilidade em se acumular no ambiente, fazendo com que estes metais tóxicos sejam deletérios para o ambiente aquático e consequentemente para os seres humanos, os quais dependem de produtos provenientes do ambiente terrestre como fonte de alimentação ( MAGES e col., 2001; Ll e col., 2008).

Muitos metais exercem funções essenciais no metabolismo e todos têm potencial para causar danos ecotoxicológicos. Por isso, são importantes poluentes persistentes no ecossistema aquático e estão especialmente presentes em ecossistemas de água doce, estuarino e costeiro expostos a altos graus de pressão urbana (SABATINI e col., 2009).

Entretanto, apenas a concentração total do metal não é um fator que governa seu impacto ambiental. A forma em que o metal se encontra no ambiente aquático é uma questão particularmente importante com relação ao seu ciclo e a sua disponibilidade. Uma vez captados, a distribuição de metais para órgãos internos ocorre como resultado do transporte do metal via sangue/hemolinfa. O plasma sanguíneo contém diversas proteínas que participam da ligação com o metal e subsequentemente o transportam para os órgãos para utilização, estoque e excreção. Dado que esta dinâmica intracelular de captação de metais é parte da regulação destes e de sua desentoxicação, fica claro que tal resposta pode ser influenciada por respostas fisiológicas oriundas do ambiente para aclimatação durante exposição crônica tanto para metais nutrientes quanto para não nutrientes (CHOWDHURY e col., 2003).

Após ter sido capturado pelo crustáceo, os metais que se encontram dissolvidos no meio e aqueles capturados a partir do alimento se tornam "biodisponíveis" para fazer parte da fisiologia do animal. Esses metais são transportados internamente até, talvez, acumularem-se em algum órgão-alvo em particular, ou serem excretados (RAINBOW, 1998). A concentração do metal acumulado no organismo depende do balanço entre tomada e perda nos diferentes órgãos, assim como no corpo como um todo. Muitos crustáceos tomam mais metal do que excretam e, portanto, podem acumulá-lo no corpo (RAINBOW, 1998; LEGRAS e col., 2000). 
Como por exemplo o cobre que uma vez absorvido, pode acumular em vários tecidos, especialmente nas brânquias, e, conseqüentemente, exercer efeitos tóxicos (MARTINS e col., 2011). Metais essenciais são sequestrados ou disponibilizados para reações bioquímicas de acordo com as necessidades metabólicas de cada organismo, enquanto que os metais não essenciais são sequestrados em compartimentos intracelulares não disponíveis (ROESIJADI, 1992).

Um metal possui potencial para se ligar a qualquer molécula com afinidade por metal. Tendo em vista que os metais possuem, tipicamente, afinidade por enxofre e nitrogênio (NIEBOER \& RICHARDSON, 1980), e que as proteínas são constituídas por aminoácidos, muitas delas contendo enxofre e/ou nitrogênio, não há carência de locais com potencial de ligação para metais dentro das células (RAINBOW, 1997; 2002). Tais afinidades fazem com que os metais sejam potencialmente tóxicos, ligando-se a proteínas ou a outras moléculas, impedindo-as de exercerem suas funções metabólicas normais (RAINBOW, 2002).

\section{Cobre}

O cobre é um dos metais mais importantes para a atividade humana e tal afirmativa é corroborada pelo fato de que os quatro metais mais consumidos mundialmente são em ordem crescente: zinco, cobre, alumínio e ferro (ARREDONDO \& NÚÑEZ, 2005). Estes metais são os mais conhecidos desde os tempos pré-históricos na composição de ligas, como bronze e latão. $\mathrm{Na}$ natureza, ocorrem como minerais sob a forma de sulfetos, carbonatos, óxidos, dentre outros. O cobre é classificado como um metal pesado, designação esta que, embora normalmente esteja associada a problemas de poluição do meio ambiente, refere-se apenas aos metais que apresentam densidade superior a 5 (ARREDONDO \& NÚÑEZ, 2005).

Do ponto de vista químico, o cobre pertence ao conjunto de elementos que constituem a primeira série do grupo de metais de transição, o qual é parte integrante de compostos químicos, apresenta número de oxidação +2 e, mais raramente, +1 . O íon cuproso $\left(\mathrm{Cu}^{+}\right)$é estável em soluções aquosas, enquanto que o íon cúprico, $\mathrm{Cu}^{2+}$, forma sais solúveis e a cor azulada de suas soluções aquosas se deve ao íon $\left[\mathrm{Cu}\left(\mathrm{H}_{2} \mathrm{O}\right)_{6}\right]^{2+}$, podendo, com menos frequência, ocorrer hidrólise, o que é evitado, adicionando-se pequena quantidade de ácido (ARREDONDO \& NÚÑEZ, 2005). 
O cobre - como muitos outros metais que ocorrem no ambiente - pode ser tanto um elemento importante na dieta, em baixas concentrações, para permitir o funcionamento das enzimas, como também pode ser tóxico, podendo levar à perda do controle neuromuscular e eventual morte em organismos com excesso do metal no sangue e tecidos (CHAVEZ-CROOKER e col., 2003a).

O cobre é um elemento natural e um micronutriente traço essencial (DiDONATO \& SARKAR, 1997; MINGHETTI e col., 2008), que garante o bem-estar de todas as formas de vida aeróbias e exerce função vital no crescimento e desenvolvimento (YANG e col., 2007; SARKAR, 1999), e no desempenho do sistema nervoso, cardiovascular, imunológico e reprodutor de seres humanos, incluindo a transcrição genética (RIBEIRO e col., 2010; MARTINS e col., 2011).

A infância representa um dos períodos mais críticos da vida em termos das necessidades de cobre. O rápido crescimento durante esse período acarreta em um aumento da demanda de cobre, já que o leite fornece baixas quantidades deste elemento (WRIGHT e col., 1991; LONNERDAL, 1996). Embora sua deficiência seja um problema durante esse estágio inicial da vida, há também um alto risco de efeitos tóxicos associados à frágil homeostase frente às altas exposições ao cobre, uma vez que as funções do fígado ainda são imaturas nas crianças (LONNERDAL, 1996; ARREDONDO \& NÚÑEZ, 2005).

O cobre integra muitas enzimas envolvidas em diversos processos biológicos vitais, assim como ativa e estabiliza enzimas, como a superóxido dismutase (SOD), a ceruloplasmina (BURY, 2003), metaloproteases (ODERMATT e col., 1993) e proteínas quinases (SHINGLES e col., 2004), incluindo a citocromo c oxidase mitocondrial. O cobre é tido como um elemento essencial para as células aeróbias dos organismos e, assim como o ferro, possui estado redox flexível e atua de modo vital na respiração celular, onde a citocromo c oxidase é uma importante proteína ligada ao cobre (BURY, 2003). No entanto, as propriedades redox do cobre podem causar rapidamente a geração de oxigênio reativo quando os níveis de cobre celulares estiverem elevados (GROSELL \& WOOD, 2002; FOSSET e col., 2005). Além dessas funções, o cobre é necessário ao transporte de elétrons nas mitocôndrias, na defesa de patógenos, na lignificação da parede cellular de células vegetais, no metabolismo da vitamina C, no metabolismo de carboidratos, na fixação de nitrogênio, na desnaturação/hidroxilação de ácidos graxos e, em cloroplastos, tanto para o transporte de elétrons (plastocianina) quanto para respostas ao estresse oxidativo (Cu/Zn SOD) (SHINGLES e col., 2004).

Além das funções supracitadas, os íons cobre podem também inibir o desenvolvimento de microrganismos provendo assim, proteção contra germes e bactérias nocivos presentes no 
ambiente (RIBEIRO e col., 2010), como o sulfato de cobre, que é amplamente utilizado como algicida na carcinocultura. A aplicação deste composto $\left(\mathrm{CuSO}_{4}\right)$ em tanques também é efetiva para redução do fitoplâncton em excesso, incluindo a cianobactéria Mycrocystis e outras algas azuis e verdes. Além de ser mundialmente utilizado para inibir o crescimento de algas em reservatórios, piscinas e sistemas de refrigeração industrial, o cobre na forma de sulfato também é um componente importante para a preservação de madeiras, na galvanoplastia e na manufatura de corantes. Além destas funções micro e macroestruturais, um dos principais usos do cobre se dá na produção de fios condutores de eletricidade e de ligas de latão e bronze, e como fertilizante e fungicida na agricultura (ARREDONDO \& NÚÑEZ, 2005).

Para os crustáceos, o cobre é um dos mais importantes elementos porque possui funções indispensáveis em grande número de enzimas (LI e col., 2007; YANG e col., 2007; MARTINS e col., 2011), além de ser um dos componentes essenciais necessários para a síntese de hemocianina nos crustáceos. O cobre, porém, pode ser potencialmente tóxico para os organismos quando em excesso na água (MARTINS e col., 2011), além de provocar efeitos adversos nos níveis tecidual, celular e molecular (ODERMATT e col., 1993; YANG e col., 2007), podendo alterar tanto o controle do sistema endócrino, quanto o do neurológico, provocando alterações celulares em diversos sistemas do corpo (HANDY, 2003), como, por exemplo, na reparação tecidual, situação para a qual o cobre normalmente é necessário (BOUSKILL e col., 2006).

Enzimas dependentes do cobre utilizam a habilidade do cobre em prontamente alterar seu estado de oxidação, de cuproso $\left(\mathrm{Cu}^{+}\right)$para cúprico $\left(\mathrm{Cu}^{2+}\right)$, na catalisação de reações redox fundamentais. No entanto, essa mesma característica dos íons cobre pode levar à citotoxicidade, através da produção de ROS (espécie reativa de oxigênio) e outros radicais livres altamente prejudiciais. Assim, com tais alterações, é possível detectar nos organismos a existência de mecanismos de homeostase sofisticados, os quais envolvem a regulação da tomada, da distribuição, do sequestro e da exportação de cobre (MINGHETTI e col., 2008).

O cobre é potencialmente prejudicial à saúde humana devido à sua persistência, toxicidade e poder de bioacumulação (SABATINI col., 2009). Organismos aquáticos captam e acumulam metais, tanto a partir de fontes alimentares como aqueles dissolvidos no meio externo. Tais metais podem ser acumulados nos organismos aquáticos e facilmente transferidos, através da cadeia alimentar, para consumidores finais, incluindo os seres humanos (SABATINI e col., 2009). Os tecidos dos crustáceos são capazes de acumular cobre de 
acordo com a concentração externa do metal. Porém, se houver alta concentração de cobre, sua toxicidade pode causar diversas e sérias implicações para proteínas que requerem cobre como parte integrante de sua estrutura (LI e col., 2007; YANG e col., 2007).

Na matéria-viva, o cobre apresenta dois estados de oxidação: cuproso $\left(\mathrm{Cu}^{+}\right)$e cúprico $\left(\mathrm{Cu}^{2+}\right)$; este último amplamente solúvel, enquanto que a solubilidade do $\mathrm{Cu}^{+}$gira em torno de concentrações submicromolares (ARREDONDO \& NÚÑEZ, 2005), sendo, portanto, um metal de transição capaz de apresentar dois estados redox, oxidado $\mathrm{Cu}^{2+}$ e reduzido $\mathrm{Cu}^{+}$, desde que possa aceitar um elétron de redutores fortes tais como ascorbato e glutationa reduzida (GALHARDI e col., 2004; ARREDONDO \& NUÑEZ, 2005). Virtualmente, todos os organismos requerem cobre como cofator catalítico para processos biológicos como respiração, transporte iônico, proteção ao estresse oxidativo, produção de hormônios e peptídeos, pigmentação, coagulação sanguínea, crescimento e desenvolvimento celulares normais. No entanto, o cobre também participa de reações redox que geram radical hidroxil, o qual causa danos a lipídios, proteínas e DNA. Além disso, este metal está intimamente associado a doenças neurodegenerativas, como esclerose múltipla amiotrópica, Alzheimer (PUIG \& THIELE, 2002), além das doenças de Wilson e Menkes, sendo estas duas últimas doenças de origem cromossômica. A doença de Wilson está associada ao acúmulo de cobre no fígado, retina, rins, coração, sistema nervoso central e ossos, levando seu portador à morte (FATEMI \& SARKAR, 2002), enquanto que a doença de Menkes está associada à não absorção do cobre proveniente do meio externo, alterando assim diversas funções corpóreas de seus portadores, afetando diretamente intestino, rins, além de causar hipotonia muscular, sendo esta última característica bastante proeminente nestes pacientes (ODERMATT e col., 1993; FATEMI \& SARKAR, 2002).

Embora existam importantes fontes naturais de cobre, a diversidade da atividade humana como indústria, agricultura, atividade portuária (MAAZOUZI e col., 2008) tem aumentado consideravelmente a adição deste metal nos ambientes estuarino e marinho ao redor do mundo (MARTINS e col., 2011), e a deposição antropogênica do cobre no ambiente marinho é substancial (KRÅNG \& EKERHOLM, 2006), já que é amplamente utilizado na indústria mundial (MAAZOUZI e col., 2008).

Mesmo sendo um elemento químico essencial, o cobre é indispensável nos processos bioquímicos relacionados à manutenção e ao equilíbrio de diversos organismos vivos, quando em excesso, também pode se tornar prejudicial. A presença de concentrações elevadas deste metal em sistemas aquáticos pode eliminar ou inibir o crescimento de espécies sensíveis como 
as dáfnias e lesmas que são importantes fontes de alimento para os peixes, comprometendo a cadeia alimentar (MAAZOUZI e col., 2008).

Mesmo se considerarmos que pouco se sabe sobre os mecanismos pelos quais o cobre e sua homeostase afetam as células (e vice-versa) (ODERMATT e col., 1993), é sabido, hoje em dia, que a toxicidade do cobre pode ser modificada pela exposição prévia subletal ao metal, o que pode levar a uma alta tolerância que é variável entre os organismos. O cobre se torna tóxico no caso de excessivo acúmulo intracelular, podendo gerar ROS e dar início a processos apoptóticos (GROSELL e col., 1997). Para que a toxicidade por cobre seja evitada, é de suma importância que a concentração intracelular deste metal seja regulada de modo muito fino (FATEMI \& SARKAR, 2002) pelas células.

O efeito letal do cobre nos organismos aquáticos é bem conhecido, já que o cobre é usado como moluscida na endemia em países africanos, para controlar o caramujo intermediário do parasita tremátoda, Schistosoma sp. (WOLMARANS \& YSSEL, 1988; VOSLOO e col., 2002).

A toxicidade relacionada à exposição ao cobre tem sido mais frequentemente reportada em ambientes aquáticos e a exposição via água parece ser a mais potente em exercer os efeitos tóxicos do metal, quando ocorre exposição aguda (GROSELL e col., 2004). O cobre é geralmente tóxico para a vida aquática e os mecanismos de toxicidade são, talvez, mais conhecidos em peixes teleósteos. Sob exposição aguda, os efeitos adversos nas funções respiratórias e ionorregulatórias são tão dramáticos que a toxicidade é explicada pelo dano direto em órgãos alvos específicos (como, por exemplo, brânquias) de peixes. Claramente, o distúrbio endócrino é menos relevante nesse caso, mas a situação pode ser diferente quando se considera um período maior de tempo, com níveis subletais baixos (caracterizando exposição crônica) (HANDY, 2003). É importante considerar, então, a possibilidade de que o cobre possa ser transferido ao longo da cadeia trófica e, eventualmente, atingir concentrações tóxicas nos níveis altos da cadeia (PINHO e col., 2007).

Os metais são notados por seus efeitos deletérios nos processos de tomada de íons. Em peixes de água doce, o principal local de toxicidade de metais é as brânquias, onde estes metais primariamente inibem o transporte de enzimas na membrana basolateral. Para exercer esta ação tóxica, o metal tem que entrar nas brânquias e atravessar o citoplasma. Há evidências de que a rota de entrada nas brânquias de peixes para metais é ligada ao processo de tomada de cátions, o qual é perturbado pelos metais (BURY \& WOOD, 1999). 
A exposição ao cobre acarreta três respostas em Carcinus maenas (HEBEL e col., 1997), gerando uma cascata de reações: (i) comportamentais - de fuga, locomoção, alimentação e reprodução; (ii) celulares - ultraestrutura das brânquias, metalotioneína, proteínas de estresse, enzimas e lisossomos; e (iii) fisiológicas - regulação iono-osmótica (osmolaridade da hemolinfa e balanço iono-catiônico), circulação (taxa cardíaca, perfusão branquial) e respiração. De acordo com HEBEL e col. (1997), é de suma importância verificar todo esse leque de respostas obtidas nos diferentes níveis do organismo, após a exposição ao cobre na água.

\section{Mangue}

Os ecossistemas de maguezais - biota de localização dos estuários - são bastante antigos e, possivelmente, surgiram logo depois das primeiras angiospermas, por volta de 114 milhões de anos atrás (DUKE, 1992). Avicennia sp e Rhyzophora sp foram provavelmente os primeiros gêneros a evoluir, surgindo próximo do final do período Cretáceo (KATHIRESAN \& BINGHAM,

2001). Os registros obtidos a partir de pólens provêm importantes informações sobre a subsequente radiação desses gêneros, os quais têm sido estudados há muito tempo, com descrições de Nearchus (325 a.C.) e Theophratus (305 a.C.) acerca de árvores de Rhizophora sp no mar vermelho e Golfo Pérsico, sendo estes os achados mais antigos encontrados na literatura (KATHIRESAN \& BINGHAM, 2001).

Este ecossitema consiste de plantas/árvores que crescem na interface entre a terra e o mar, em latitudes tropicais e subtropicais, e está entre os ecossistemas mais produtivos do mundo, enriquecendo as águas costeiras, gerando produtos da floresta que podem ter caráter comercial, e protegendo a linha da costa. As plantas do mangue se encontram, em geral, associadas a microorganismos e fungos. As plantas junto com os animais constituem a comunidade da floresta do mangue e esta comunidade em conjunto com fatores abióticos constituem o ecossistema do mangue, o qual, por sua vez, encontra-se exposto a condições de alta salinidade, extremo de marés, ventos fortes, altas temperaturas e umidade, bem como solo anaeróbio (KATHIRESAN \& BINGHAM, 2001).

As florestas de manguezais são ecossistemas produtivos encontrados ao longo da zona costeira do Brasil até Santa Catarina, e constituem fontes de materiais aproveitáveis pelo homem, tais como madeira, produtos medicinais, corantes naturais, peixes, crustáceos e moluscos. Para as populações ribeirinhas do nordeste brasileiro, os caranguejos Brachyura constituem a maior 
fonte econômica dessas populações, e as principais espécies comercializadas são o caranguejo guaiamum (Cardisoma guamhumi), o siri (Callinectes spp) e o caranguejo terrestre "caranguejo-uçá" (Ucides cordatus) (ALVES e col., 2005).

A variação da concentração de oxigênio no ambiente, afetando direta e indiretamente os organismos de modo geral, é uma das principais características de áreas estuarinas, restingas, mangues e lagos costeiros. A capacidade de tolerar variações da concentração de oxigênio no ambiente é um dos pré-requisitos para os organismos viverem em tais habitats (MACIEL e col., 2008), uma vez que os estuários são também ambientes transitórios entre água salgada e doce, apresentando grandes flutuações de salinidade e temperatura, sendo o mangue um ambiente caracterizado por flutuações periódicas de salinidade, temperatura e exposição ao ar. A sobrevivência de organismos em tal ambiente favoreceu a evolução de mecanismos comportamentais e/ou fisiológicos para minimizar os efeitos dessas alterações (BAMBER \& DEPLEDGE, 1997; VITALE e col., 1999). Nesses habitats, no entanto, ocorre uma grande diversidade de espécies (LUCU \& TOWLE, 2003), com a presença de animais osmorreguladores, como caranguejos eurialinos, os quais sobrevivem em um ambiente físico geralmente hostil devido à baixa salinidade ou a flutuação desta. Tais habitats também são locais de poluição de origem antropogênica, provocada por compostos como metais.

As regiões estuarinas e costeiras recebem despejos de poluentes tanto de fontes específicas quanto de não específicas. Os portos marítimos em especial, as cidades costeiras ou outras áreas industriais, que se encontram ao logo da costa, recebem despejos crônicos de metais (FERRER e col., 2006) e os mangues, devido à sua proximidade a centros populacionais e regiões industrializadas, têm recebido consequentemente, dejetos contendo metais. E como consequência, os sedimentos podem ser fontes significativas de contaminação por esses metais (RIVAIL e col., 1996; TAM \& YAO, 1998; KATHIRESAN \& BINGHAM, 2001). 


\section{Crustáceos}

Os crustáceos formam um grupo muito diverso de organismos que ocorre numa ampla variedade de ambientes, incluindo água doce, marinha e ambiente terrestre. $\mathrm{O}$ grande número de espécies encontradas nestes ambientes tão diferentes entre si é em grande parte decorrente de uma plasticidade fisiológica observada nesse grupo taxonômico como um todo (AHEARN e col., 1999; MARTINEZ e col., 1999). As mudanças funcionais observadas nesses organismos envolvem adaptações das células epiteliais encontradas nas brânquias, tegumento, hepatopâncreas, glândula antenal, permitindo, desse modo, a regulação feita pelo animal para a passagem de moléculas e íons, entre o meio externo e a hemolinfa. Tais adaptações podem ocorrer nos níveis molecular, celular ou tecidual e tais especializações teciduais podem ser modificadas por meio de controle hormonal sistêmico (AHEARN e col.,1999; MARTINEZ e col., 1999; RINDERHAGEN e col., 2000).

BROUWER e col. (1997) afirmaram que os crustáceos são frequentemente utilizados como bioindicadores em diversos sistemas aquáticos (BORKOVIĆ e col., 2008). Trata-se de um grupo interessante para investigações comparativas (RINDERHAGEN e col., 2000), conferindo-Ihe grande interesse biológico para a pesquisa fundamental e/ou alto valor comercial (TOULLEC, 1999).

Estes animais frequentemente ingerem consideráveis quantidades de íons de metais provenientes da dieta e do meio que os cerca. Em baixas concentrações, alguns desses metais, como zinco, ferro e cobre, podem ter importantes funções biológicas na ativação enzimática ou síntese de pigmentos respiratórios. Porém, em altas concentrações se tornam tóxicos e podem afetar as funções nervosas e musculares ( CHAVEZ-CROOKER e col., 2002; MAAZOUZI e col., 2008)

Alguns crustáceos marinhos (como siris) apresentam uma elevada necessidade por cobre para composição de seu pigmento respiratório (hemocianina). Antes da muda, o caranguejo cessa sua alimentação e usa a hemocianina como reserva energética, resultando numa liberação de cobre na hemolinfa do animal, disponibilizando dessa forma o metal para os demais órgãos do animal. No ato da muda, os caranguejos "captam" grande quantidade de água para prover a pressão hidrostática necessária para a ruptura do exoesqueleto antigo e para criar um aumento do espaço para crescimento do novo esqueleto. 
Após a muda, os caranguejos precisam restaurar a concentração de hemocianina para os níveis pré-ecdise, fazendo com que uma grande quantidade de cobre seja liberada nas rotas de secreção para a síntese de hemocianina (BROUWER e col., 2002). Os crustáceos, porém, apresentam alta sensibilidade a metais como demonstrado em cladócera, Moina macrospora, em camarões, Crangon crangon e Paratya australiensis, no camarão fantasma, Callianassa australiensis, no camarão peneído, Penaues merguiensis, na lagosta, Homarus americanus, e no caranguejo, Carcinus maenas (BAMBANG e col., 1995).

Para animais que habitam ambientes poluídos, pode haver desenvolvimento de tolerância às concentrações mais elevadas no meio (CANLI \& FURNESS, 1993). Mas em contrapartida, os metais podem se tornar tóxicos quando presentes em concentrações suficientemente altas no ambiente. O cobre, em especial, está entre um dos metais mais tóxicos na biota de água doce e, frequentemente, seu aumento causa danos irreversíveis em algumas espécies como Angopecten irradians, Brachydanio rerio, em concentrações acima dos níveis necessários para o crescimento e reprodução (GUNER, 2007) que variam de animal para animal.

Os caranguejos são membros característicos da fauna de invertebrados do mangue e têm recebido muita atenção (KATHIRESAN \& BINGHAM, 2001), já que dentro do ambiente complexo do manguezal, esses animais fazem parte de diversos nichos. Para algumas espécies a relação com o manguezal é obrigatória e, portanto, há dependência direta do mangue para sobreviver (KATHIRESAN \& BINGHAM, 2001).

Os caranguejos de mangue são morfologica, fisiologica e comportamentalmente bem adaptados ao seu ambiente (KATHIRESAN \& BINGHAM, 2001) e se "ajustam" a flutuações significativas de temperatura e salinidade (MICHELI e col., 1991). Tal adaptação é vista nesses decápodas brachyura, tanto de espécies marinhas quanto de água doce, que geralmente possuem nove pares de brânquias, enquanto que o caranguejo de mangue Ucides cordatus possui somente sete pares de brânquias, podendo permanecer por longos períodos em ambiente seco de seu habitat nativo (MARTINEZ e col., 1999). 


\section{Ucides cordatus}

Ucides cordatus (L.) é um caranguejo Ucidideo, considerado o maior Ocypodidae de mangue (HARTNOLL, 1988) e hoje pertence à família Ucididae (STEVCIC, 2005), presente num ambiente com condições flutuantes, devido ao ciclo de maré e à constante instabilidade do tempo, muito comuns em regiões tropicais. Ucides cordatus é considerado um bom osmorregulador, capaz tanto de hipo quanto de hiperosmorregular e, embora seja o gecarcinídeo aquático (MARTINEZ e col., 1999), possui dispositivos respiratórios que se assemelham aos dos caranguejos terrestres (SANTOS \& SALOMÃO, 1985). Além de ser um caranguejo que faz incursões terrestres na maré baixa, quando ocorre a limpeza da toca (MARTINEZ e col., 1999), apresenta comportamentos de construção e alimentação fora da água por diversas horas (MARTINEZ e col., 1999), ficando, portanto, diretamente exposto a contaminantes depositados no ambiente (MARTINEZ e col., 1999; NUDI e col., 2007).

O caranguejo Ucides cordatus está amplamente distribuído em habitats ao longo da costa brasileira habitando tocas individuais com até 1 metro de profundidade, situadas abaixo das árvores do mangueAlém destes, uma alta pressão predatória do Ucides cordatus é exercida pelos seres humanos que usam o caranguejo como alimento (ALVES e col., 2005).

Ucides cordatus, um excelente hipo-hiperregulador, como citado anteriormente, é considerado um importante membro da fauna do manguezal na costa Atlântica do continente americano. É também, naturalmente, uma espécie exposta a flutuações da salinidade, a qual pode variar de 2 a 33\%o e consegue manter uma concentração de sódio entre 300 e 390 mM, em salinidade acima de 34\% (SANTOS \& SALOMÃO, 1985). Esse fatores indicam a presença de mecanismos osmorregulatórios evoluídos capazes de bombear $\mathrm{NaCl}$ do meio externo para hemolinfa em salinidade abaixo de $26 \%$ e também, em meios mais concentrados, secretarsódio e cloreto (MARTINEZ e col., 1999). 


\section{Tomada de Cobre}

Os metais são tomados e acumulados pelos organismos aquáticos, tanto pelo meio em que vivem quanto via dieta (RAINBOW, 2000). Invertebrados aquáticos "tomam" e acumulam metais essenciais ou não, e todos estes apresentam potencial para causar efeitos tóxicos (RAINBOW, 2007). Os mecanismos de homeostase do cobre envolvem um balanço intrínseco entre tomada, distribuição e vias de utilização, acúmulo e desentoxicação, e efluxo de cobre (FONTAINE \& MERCER, 2007).

Nas águas não poluídas, os peixes obtêm muito do cobre necessário pela absorção através da alimentação e, consequentemente, a tomada de cobre pelas brânquias é provavelmente a de menor contribuição para o total de cobre presente no organismo como um todo. No entanto, a situação é muito diferente em águas poluídas por cobre. As brânquias das trutas "arco-íris"(Oncorhyncus mykiss) podem apresentar um aumento de 10x no acúmulo de cobre em um intervalo de poucas horas durante exposição na água e consequentemente há registros de altas concentrações de cobre no sangue destes animais (CAMPBELL e col., 1999). Enquanto que a necessidade de cobre em peixes é claramente obtida pela dieta através da ingestão, a homeostase de cobre nas brânquias tem sido observada e sugere-se então que as brânquias possam servir como rota de tomada de cobre (GROSELL \& WOOD, 2002).

Estudos têm demonstrado que metais dissolvidos podem ser tomados por uma ou mais vias, dependendo do habitat e a fisiologia do crustáceo, de acordo, por exemplo, com o grau de adaptação ao estuarino ou ambiente de água doce (RAINBOW, 2000). A lagosta, em particular, é uma espécie que apresenta diversos caminhos/rotas para bioacumulação de metais e outros poluentes, absorvendo-os através da superfície branquial, por ingestão de água e sedimento e pelo consumo de organismos que já estão previamente contaminados por metais (MORALES-HERNANDEZ e col., 2004).

A superfície externa dos crustáceos é coberta por uma cutícula secretada pelas células epiteliais. Pequenos crustáceos são tipicamente permeáveis como um todo, enquanto que grandes malacostracas (como lagosta, camarão) podem restringir a permeabilidade a regiões selecionadas, como as brânquias. A cutícula impermeável atua como um local para absorção passiva de metais dissolvidos, mas alguns metais não são transportados para o corpo do crustáceo e não serão considerados neste texto (RAINBOW, 2000). 
O acúmulo de metais em invertebrados aquáticos pode ocorrer de duas formas: (i) metal em sua forma metabolicamente disponível; (ii) metal que tenha sido destoxificado e, portanto, não mais disponível para exercer qualquer função no metabolismo, seja esta deletéria ou não (RAINBOW, 2002). Há ao menos três processos de destoxificação para controle da concentração de metais nos tecidos dos crustáceos (i) metalotioneínas e glutationa; (ii) precipitação de concreções do metal no vacúolo ou lisossomo; (iii) sequestro mitocondrial (CHAVEZ-CROOKER e col., 2003b).

De acordo com VIARENGO \& NOTT (1993), o mecanismo de sequestro do metal em vesículas pode representar uma estratégia generalizada para homeostase do cátion metálico (MOUNEYRAC e col., 2001), para manter a concentração dos metais essenciais dentro de limites fisiológicos toleráveis e para minimizar seus efeitos deletérios. Todos os eucariontes apresentam numerosos mecanismos que controlam a tomada, o acúmulo, o tráfego e a destoxificação de metais sendo que os principais componentes da homeostase de metais são transporte, quelação e compartimentalização (SHINGLES e col., 2004).

Geralmente, a tomada ocorre através das superfícies epiteliais relacionadas à absorção e excreção de íons, tais como membranas branquiais de peixes e crustáceos. Além disso, o cobre pode competir com outros cátions pelos sítios de ligação e na tomada nas brânquias (MARTINS e col., 2011). A tomada de metais dissolvidos pelos crustáceos é potencialmente afetada pelas propriedades físico-químicas do metal em solução e, também, por quaisquer alterações fisiológicas do crustáceo, tais como estágio do ciclo da muda e/ou respostas às alterações na salinidade (RAINBOW, 2000).

Uma vez dentro da célula, os metais se tornam metabolicamente disponíveis, até que se liguem a partículas ou moléculas de alta afinidade das quais o metal, sob condições normais, não se desliga. Par que haja a destoxificação do metal (MASON \& JENKINS, 1995) é necessária a ligação do metal a proteínas tais como metalotioneínas (MT) ou grânulos insolúveis (VIARENGO, 1989; ROESIJADI, 1992; LANGSTON col., 1998; RAINBOW, 2002). Quando os íons cobre entram no compartimento intracelular das células branquiais, eles se ligam a proteínas estruturais intracelulares e a mensageiros químicos, resultando na ativação de mecanismos celulares de destoxificação (ENGEL \& BROUWER, 1989; HEBEL e col., 1997). Os níveis corpóreos de metais essenciais, como cobre e zinco, podem ser regulados por alguns crustáceos (particularmente decápodas), enquanto que o processo de acúmulo destes metais somente se inicia quando os mecanismos de regulação param de funcionar (CANLI \& FURNESS, 1993). 
Estudos anteriores demonstraram que o cobre captado do meio aquático e distribuído para a hemolinfa é excretado, para que sejam mantidos os níveis de cobre na hemolinfa relativamente constantes (RTAL e col., 1996; RAINBOW, 2002; 2007; SÁ e col., 2008; MARTINS e col., 2011). Diversos invertebrados aquáticos desenvolveram uma grande variedade de processos regulatórios, dentro da célula, visando a redução da concentração circulante dos metais, como cobre (CHAVEZ-CROOKER e col., 2003b).

Cátions presentes na água do mar, como sódio, magnésio e cálcio, podem competir com o cobre por sítios de ligação ativos nas brânquias de peixes e crustáceos, enquanto que ânions, como cloreto, associam-se ao cobre, reduzindo assim a biodisponibilidade deste metal (LAUREN \& McDONALD, 1986; GROSELL \& WOOD, 2002; BIANCHINI e col., 2004; MARTINS e col., 2011). Diversos efeitos adversos do cobre têm sido descritos, em especial com respeito à osmorregulação, respiração, absorção, armazenamento e secreção deste cátion (LI e col., 2007).

\section{Brânquias}

Crustáceos da região estuarina apresentam, como resultado do processo de seleção natural, diversos mecanismos de regulação para viver entre os ambientes aquático e terrestre, e são conhecidos como organismos hiperosmorreguladores ou hiperhipoosmorreguladores. Nos dois casos, suas brânquias apresentam diversas modificações morfofisiológicas. Muitos órgãos se encontram envolvidos na osmorregulação dos crustáceos, incluindo, além das brânquias, a glândula antenal, parte do intestino e o hepatopâncreas (TSAI \& LIN, 2007). Perdas de íons por difusão, devido ao aumento da permeabilidade das brânquias, como acontece no caranguejo azul Callinectes similis, pode explicar a menor habilidade de algumas espécies em osmorregular, o que lhes impõe um limite para a invasão do ambiente de água doce, em contraste com aquilo que ocorre em espécies hiperosmorreguladoras, as quais são aptas a invadir esse ambiente (LUCU \& TOWLE, 2003). 
As brânquias são apêndices modificados dos epipoditos, apresentando uma fina cutícula e ampla superfície de contato, as quais facilitam as trocas gasosas (RINDERHAGEN e col., 2000). Essas características permitem que ocorra um contato íntimo das brânquias com a água do meio externo, facilitando, também, a regulação iônica e osmótica, assim como a excreção de produtos do metabolismo, funções estas relacionadas entre si (WOOD, 1992; MARTINEZ e col., 1999; BHAVAN \& GERALDINE, 2000; LUCU \& TOWLE, 2003; WU \& CHEN, 2004; MONTEIRO e col., 2005; ROMANO \& ZENG, 2007; YANG e col., 2007). Tais funções estão presentes tanto em crustáceos osmorreguladores quanto osmoconformadores (MARTINEZ e col., 1999; REBELO e col., 2000), possuindo papel importante na osmorregulação dos crustáceos aquáticos (TSAI \& LIN, 2007).

As brânquias estão expostas ao ambiente externo e, consequentemente, expostas diretamente à água contaminada por poluentes (BURY e col., 1999; McGEER e col., 2000; WU \& CHEN, 2004; MONTEIRO e col., 2005; ROMANO \& ZENG, 2007). Além disso, as brânquias constituem uma interface seletiva entre o meio interno e o externo, o qual pode ser hostil, do ponto de vista osmótico, e por vezes poluído de modo bastante significativo (WOOD, 1992).

Para os caranguejos, quanto mais terrestre é a espécie, menor é o número de pares de brânquias (GRAY, 1957; HAWKINS \& JONES, 1982; MARTINEZ e col., 1999). A área de superfície das brânquias aumenta conforme os caranguejos se desenvolvem (de juvenis a adultos), com um aumento progressivo da área de superfície de cada lamela branquial, e não no número total de lamelas. Conforme o caranguejo cresce, há o aumento da área de superfície de suas brânquias, porém não é diretamente proporcional ao aumento da massa corpórea. As áreas massa-específicas (área dividida pela massa corpórea) das brânquias são maiores em caranguejos aquáticos e menores em caranguejos terrestres (MARTINEZ e col., 1999). A redução do número de brânquias também está relacionada com a redução da atividade e necessidade de oxigênio. No entanto, de acordo com TAYLOR \& TAYLOR (1992), a regulação entre tamanho das brânquias e habitat, ou atividade, é mais bem relacionada com a área de superfície do que com o número de brânquias (MARTINEZ e col., 1999).

Os crustáceos brachiuros decapodes apresentam dois tipos de brânquias: (i) ANTERIOR - epitélio com espessura de 1-5 $\mu \mathrm{m}$, sobressaindo para o espaço da hemolinfa e responsável pelas trocas gasosas; (ii) POSTERIOR - epitélio mais espesso, com 10-20 $\mu \mathrm{m}$, constituído por células 
chamadas ionócitos, devido às suas funções ionorregulatórias. Estes ionócitos possuem sistemas de folhetos apicais bem desenvolvidos, alternando com os espaços subcuticulares extracelulares. Entre estes folhetos e acima deles há um grande número de mitocôndrias e invaginações profundas, localizadas na membrana basolateral, com mitocôndrias associadas ao transporte iônico ativo (REBELO e col., 2000; TSAI \& LIN, 2007). Segundo PILLER e col. (1995), as brânquias anteriores são responsáveis pelas trocas gasosas, além de exercer indispensável função no transporte de ferro e cobre (YANG e col., 2007), e as posteriores são responsáveis pela regulação iônica e osmótica (TOWLE \& WEIHRAUCH, 2001; MARTINS e col., 2011). Tendo em vista tais características, altas concentrações de cobre junto às brânquias podem causar distúrbios osmorregulatórios e/ou perturbação respiratória (GROSELL \& WOOD, 2002).

A água contaminada com cobre e zinco também interfere na função respiratória das brânquias dos crustáceos, resultando na redução da eficácia da transferência de gases, com diminuição do consumo de oxigênio e do trabalho cardíaco (HARRIS \& SANTOS, 2000). A água, contendo metais, como cobre e cádmio, exerce, inicialmente, efeitos tóxicos em locais da superfície branquial, onde ocorre atividade fisiológica, interferindo diretamente no transporte iônico (MATSUO e col., 2005). A ligação de cátions metálicos em locais-alvos nas brânquias é determinante para a toxicidade de metais, em peixes. Fatores geoquímicos, como competição e ligação, interferem na disponibilidade do metal livre na água e podem afetar a biodisponibilidade dos cátions metálicos aos peixes, assim como a sua toxicidade (MATSUO e col., 2005). Há poucas informações a respeito da interação entre os efeitos das concentrações subletais de metais e variáveis ambientais (como salinidade) sobre e a estrutura das brânquias dos crustáceos (LAWSON e col., 1995).

\section{Hemolinfa}

A exposição prolongada ao cobre, na água, resulta na tomada deste metal (WRIGHT, 1995) e na ligação do íon junto a sítios moleculares dentro do organismo (RAINBOW, 1995). As brânquias, por todas as características já mencionadas anteriormente, constituem o local inicialmente afetado pelo cobre (HEBEL e col., 1997), disponibilizando para o meio interno do animal através da hemolinfa.

RTAL \& TRUCHOT (1996) demonstraram que a hemolinfa exerce função no transporte de cobre exógeno, para locais de acúmulo nos tecido, sugerindo que a hemolinfa não seja 
considerada um local de bioacúmulo. Além disso, esse transporte ocorre, principalmente, em associação ao pigmento respiratório hemocianina. Esta proteína, portanto, é a molécula responsável pela associação desse metal na hemolinfa (RTAL e col., 1996). Além disso, ela tem, também, importante capacidade de se ligar a outros metais e atua de modo importante no transporte de cobre exógeno, para locais de acúmulo nos tecidos (RTAL e col., 1996). Tal afirmação é particularmente verdadeira para crustáceos decápodas, os quais requerem cobre para a biossíntese da maioria das proteínas ligadas a este metal (RTAL e col., 1996).

\section{Hepatopâncreas}

Este órgão multifuncional consiste de centenas de tubos, os quais terminam em fundo cego, compostos por diferentes tipos de células epiteliais, as quais se encontram localizadas ao longo do eixo maior desses tubos (WU e col., 2008). Cada um desses tubos pode ser dividido em distal, médio e proximal, em relação ao trato digestório principal, e todos convergem para a porção proximal do duto do hepatopâncreas (BRUNET e col., 1994; CORRÊA Jr e col., 2002; MANDAL e col., 2003). Os produtos da digestão e outros componentes da dieta passam do lúmen do estômago para os túbulos desse órgão, onde solutos orgânicos e inorgânicos são transferidos para o epitélio celular e, através deste, para a hemolinfa, permitindo a distribuição desses componentes para o restante do corpo do animal (MANDAL e col., 2003).

O hepatopâncreas, análogo ao fígado, também combina muitas funções do fígado, pâncreas e intestino de vertebrados (MANDAL e col., 2003), assim como exerce funções importantes em diversos processos metabólicos nos crustáceos (CACECl e col., 1988; BHAVAN

\& GERALDINE, 2000). Estudos anteriores acerca da estrutura, desenvolvimento, fisiologia, metabolismo e bioquímica do hepatopâncreas concluíram que este é um órgão digestório com funções que incluem absorção, digestão, armazenamento e secreção de substâncias (CACECl e col., 1988; WU e col., 2008)

O hepatopâncreas de crustáceos possui diversas funções, incluindo digestão, emulsificação e absorção de nutrientes da dieta, regulação da concentração iônica celular e da hemolinfa, através de processos de absorção e secreção (CORRÊA Jr e col., 2002), além da estocagem de carboidratos, lipídios e proteínas, síntese de hemocianina e sequestro e destoxificação de uma série de xenobióticos, incluindo os metais. Alguns autores sugerem que os metais sejam acumulados em vacúolos intracelulares do hepatopâncreas, como os lisossomos, e consideram tal acúmulo como um mecanismo de destoxificação, por meio do 
qual ocorre uma redução da transferência de substâncias, do lúmen do túbulo para a hemolinfa (ALCORLO e col., 2006; MANDAL e col.,2006; GUNER, 2007). Além dessas funções, o hepatopâncreas também controla a tomada de cátions divalentes (como cálcio e cobre) do trato gastrintestinal e os estoca em organelas do epitélio hepatopancreático, incorpora-os a partir de vias de biossíntese, tais como a da biossíntese de hemocianina (CHAVEZ-CROOKER e col., 2002). O hepatopâncreas possui, ainda, a capacidade de concentrar metais oriundos da hemolinfa e do trato digestório, de estocá-los em vacúolos intracelulares das células $F$ e $R$, e é considerado ao lado da glândula antenal, o principal órgão de destoxificação (ALCORLO e col., 2006). Além das células $R$ e $F$, foram encontrados no hepatopâncreas dois outros tipos celulares, denominados células E e B (MANDAL e col., 2003). Os quatro tipos celulares possuem diferentes composições de organelas para executar funções específicas, como digestão, absorção, secreção, osmorregulação e destoxificação (CHAVEZ-CROOKER e col., 2001).

O primeiro tipo celular, o de menor densidade em relação aos demais, é denominado célula E (embriônica), localizada, principalmente, na porção distal dos túbulos (CORRÊA Jr e col., 2002; CHAVEZ-CROOKER e col., 2003a) e origina as demais células que compõem o hepatopâncreas (DAVIS \& BURNETT, 1964; AL-MOHANNA e col., 1985; CHAVEZ-CROOKER e col., 2003 a;b). Essas células embriônicas são mitóticas e funcionam de maneira muito parecida com algumas células do intestino, dando origem a duas linhagens de células: (i) linha absortiva, geradora de novas células $\mathrm{R}$, que são bastante parecidas com as células colunares do intestino; (ii) linha secretora, composta por células F que sintetizam e secretam enzimas digestivas, como o fazem as células do estômago (CHAVEZ-CROOKER e col., 2001;2003a), além de atuarem no estoque de lipídeos, carboidratos e proteínas, síntese de hemocianina, regulação tanto de íons divalentes como monovalentes, e destoxificação de uma ampla variedade de xenobióticos (CHAVEZ-CROOKER e col., 2003a).

As células $\mathrm{R}$ (reabsortivas) se encontram principalmente localizadas na região intermediária do túbulo. São, em geral, consideradas células absortivas e de estoque do epitélio, e responsáveis pelo seqüestro de gordura, glicogênio e cátions divalentes, incluindo o cálcio e uma variedade de metais. São, portanto, células relacionadas com a assimilação e armazenamento de nutrientes (AL-MOHANNA \& NOTT, 1987; BRUNET e col., 1994; CHAVEZCROOKER e col., 2003a). Assim como as células $R$, as células $F$ (fibrilar) também são encontradas na região tubular intermediária e estão envolvidas na síntese de enzimas e produção de zimógeno (AL-MOHANNA \& NOTT, 1989; CORRÊA Jr e col., 2002). 
As células B ("bolha") apresentam a maior densidade de células em relação aos outros tipos celulares. São derivadas das células $\mathrm{F}$ e aparentam ter função significativa na digestão intracelular e na excreção de produtos lisados, oriundos da digestão e de xenobióticos (CHAVEZ-CROOKER e col., 2001). Atuam, também, junto com as células F, nos processos de síntese de proteínas e de secreção enzimática (LOIZZI, 1971; GIBSON \& BARKER, 1979; CHAVEZ-CROOKER e col., 2003a). As células B também denominadas secretoras, são encontradas na região intermediária e proximal dos túbulos, e provavelmente atuam na digestão e excreção, através do processo de auto-extrusão (CORRÊA Jr e col., 2002).

Além de todas as funções citadas anteriormente, BRYAN (1968) e outros autores confirmaram a dominância do hepatopâncreas como órgão de estocagem de metais (MOUNEYRAC e col., 2001), uma vez que os metais ingeridos junto com o alimento são primeiramente ligados às células da glândula digestória e, em seguida, transportados para os demais órgãos (ROESIJADI, 1992). Uma vez que o hepatopâncreas assim como o fígado são muito sensíveis a diferentes dietas e poluentes presentes na água, estes órgãos são frequentemente utilizados para monitorar os efeitos de vários poluentes (BAUTISTA e col., 1994; WU e col., 2008), chamando, assim, a atenção de diversos pesquisadores (WU e col., 2008).

\section{Destoxificação}

Em sistemas aquáticos naturais, os organismos são expostos a variadas concentrações do cobre normalmente presente nesses sistemas e também presente, em alguns casos, por adição antropogênica. O ajuste ou aclimatação a tais concentrações pode resultar num aumento da tolerância (BOSSUYT \& JANSSEN, 2005) por meio de uma regulação, a qual pode ocorrer tanto por uma modificação na cinética de tomada quanto por processos que envolvem excreção ativa e/ou estoque de cobre inerte (DANG e col., 2009). Fora essas rotas, os organismos também podem destoxificar metais por meio do isolamento destes em seus tecidos, seja sob a forma de grânulos ou precipitados insolúveis do metal, ou pela sua excreção. Além disso, alguns caranguejos e camarões acumulam metais na camada de quitina externa (exoesqueleto), a qual é periodicamente eliminada, durante o crescimento do animal (BOSSUYT \& JANSSEN, 2005).

Em invertebrados, dois importantes mecanismos de destoxificação que envolvem ligantes intracelulares têm sido bem documentados: a existência de ligante metal para 
componentes citosólicos, incluindo metalotioneínas (ou proteínas com afinidade), e biominealização (MASON \& JENKINS, 1995; MARIGOMEZ e col., 2002). Conforme a espécie, a importância relativa destes dois mecanismos varia consideravelmente (AMIARD e col.,2006). Os grânulos de cobre estão envolvidos no metabolismo da hemocianina em gastrópodes e nos crustáceos os grânulos, contendo cobre e enxofre, também podem ser importantes na função de destoxificação, como demonstrado em espécies oriundas de áreas poluídas por cobre ou expostos experimentalmente a este metal (MOUNEYRAC e col., 2001).

\section{Estresse}

O uso de índices de estresse associados ao desenvolvimento de doenças em animais aquáticos, tanto na agricultura (HOUGHTON \& MATTHEWS, 1986) como em condições naturais (ROSS e col., 1996; STENTIFORD \& FEIST, 2005) tem sido proposto para avaliar os efeitos de poluentes, tais como metais e compostos xenobióticos orgânicos, em organismos marinhos (VIARENGO e col., 1997) principalmente.

Como observado por BATESON \& BRADSHAW (1997), JONGMAN e col. (2005) e ELWOOD e col. (2009) nos vertebrados, o estresse causa uma cascata de reações hormonais, levando à produção de cortisol e/ou corticosterona. Os hormônios da glândula adrenal apresentam inúmeros efeitos, incluindo a conversão de glicogênio em glicose, a qual pode ser usada numa fuga ou numa resposta à luta. Enquanto que os níveis desses glicocorticóides (hormônios) são frequentemente usados como indicadores do bem estar dos vertebrados, as respostas ao estresse ocorrem quando os indivíduos são expostos a situações ambientais fora do seu domínio fisiológico normal. Tal condição é indicativa de que, inicialmente, o estresse é adaptativo, e o aumento da habilidade em se lidar com ele ocorre em um período de tempo curto. Porém, em um período de tempo mais prolongado (crônico), o estresse provoca efeitos adversos em um número grande de funções bastante distintas entre si (ELWOOD e col., 2009). 


\section{Bioacúmulo}

A Ecotoxicologia é uma área interdisciplinar das ciências ambientais que envolve principalmente a toxicologia, aplicações da ecologia e a química ambiental, com foco nas interações entre esta e a biota, e cuja natureza é investigar os efeitos adversos de agentes contaminadores nos diferentes níveis da organização biológica (FENT, 2003). Portanto, o principal objetivo da ecotoxicologia é avaliar os riscos que os ecossistemas expostos a estresses ambientais sofrem, incluindo as contaminações. Embora parâmetros físico-químicos sejam essenciais para a determinação de risco, nas últimas décadas, as respostas biológicas a estresses químicos têm sido usadas como referências para determinar danos biológicos (FERRER e col., 2006), considerando processos físico-químicos, moleculares, toxicológicos, fisiológicos e ecológicos (FENT, 2003). Dessa maneira, os testes toxicológicos tornaram-se ferramentas importantes por serem utilizadas em combinação com outros métodos para obter informações de impacto ecológico causado pelos poluentes (WANG e col., 2007).

Historicamente, a avaliação da qualidade da água tem ficado restrita às análises químicas. No entanto, a quantificação da concentração do agente contaminador sozinho não fornece informações suficientes para se aferir adequadamente os seus efeitos adversos potenciais (ALMEIDA e col., 2005) e dessa maneira o modelo de bioacúmulo de metal pela biota aquático tem recentemente recebido maior atenção devido à melhor definição dos efeitos dos metais nos ecossistemas aquáticos (BORGMANN, 1998).

Como os organismos marinhos estão continuamente expostos a concentrações variáveis de metais na água do mar, e isso ocorre particularmente ao longo da costa (influenciada pelos agentes contaminadores depositados por ações de origem antropogênica), moluscos, crustáceos e outros invertebrados marinhos são conhecidos por acumular altos níveis de metais pesados em seus tecidos e ainda sobreviver nesses ambientes poluídos (VIARENGO \& NOTT, 1993).

O acúmulo de metais nos tecidos tem sido proposto como um indicador-chave da exposição crônica e para o entendimento das cinéticas de toxicidade que envolvem o acúmulo de metal durante exposição crônica subletal faz-se necessário estabelecer links entre toxicidade e o risco de exposição (McGEER e col., 2000) e o bioacúmulo é normalmente um bom indicador integrativo de exposição química de organismos em ecossistemas (LUOMA \& RAINBOW, 2005). Este autores também definiram BIOINDICADOR como um organismo, ou parte de um organismo ou uma comunidade de organismos, que contêm informações sobre a 
qualidade do ambiente/ou parte deste ambiente. Por outro lado, BELTRAME e col. (2011) definem BIOMONITOR como um organismo (ou parte de um organismo ou comunidade de organismos) que contém informações acerca de aspectos quantitativos da qualidade do ambiente (BOUSKILL e col., 2006).

Normalmente, os biomarcadores são classificados como específicos e não específicos. O uso de marcadores específicos para agentes tóxicos, como as metalotioneínas, tem sido empregado para indicar a presença de metais, embora possa haver interferência de efeitos de fatores abióticos, como salinidade (MONSERRAT e col., 2006). De acordo com as sugestões dadas por PEDERSON e col. (1997), há três importantes pontos que precisam ser considerados antes de os biomarcadores serem usados na rotina de biomonitoramento e manejo ambiental: (i) as concentrações dos biomarcadores nos tecidos refletem a extensão da contaminação crônica?; (ii) a concentração do biomarcador nos tecidos específicos reflete a contaminação de tais poluentes nestes tecidos?; (iii) as respostas de diferentes biomarcadores são consistentes entre si? (WU \& CHEN, 2005).

O mecanismo de toxicidade aguda dos metais nos animais aquáticos ocorre em sinergia com a salinidade, temperatura, presença de ligantes biológicos, oxigênio, alcalinidade, dentre outros (BAMBANG e col., 1995). A toxicidade aguda representa o primeiro nível de impacto de metais potencialmente tóxicos no ecossistema aquático. Todavia, existem organismos aquáticos que não são sensíveis à ação tóxica, mas acumulam o agente contaminador, comprometendo, no longo prazo, a sobrevida da biota. Isso ocorre porque os efeitos nocivos são potencializados ao longo da cadeia alimentar, colocando em risco os organismos situados no topo da cadeia (BAMBANG e col., 1995).

Estudos recentes têm demonstrado que a transferência trófica é crítica para o acúmulo de metal (WANG \& RAINBOW, 2000). Certos decápodas (anfípodas e lagostins) não são bons monitores de exposição de longa duração a metais, devido a uma alta capacidade de depuração desses crustáceos. O cobre presente no exoesqueleto de lagostins pode ter um valor de sobrevivência como mecanismo de eliminação através da muda (GUNER, 2007), e a toxicidade do cobre pode ser modificada por exposições subletais a este metal, as quais, por sua vez, podem levar a altas tolerâncias a este metal (DANG e col., 2009).

A resposta biológica a agressões ambientais pode ser evidenciada em qualquer nível de organização, desde ecossistemas até compartimentos subcelulares ou reações bioquímicas intracelulares, passando por comunidades, populações, organismos, sistemas fisiológicos e células. 


\section{Contextualização}

Todos os ambientes possuem um estado de equilíbrio estabelecido pela capacidade de transformação, assimilação e eliminação das formas de matéria ou energia que chegam ao sistema. Quando se introduz uma nova substância ao ambiente ou retira-se um componente importante para a manutenção do equilíbrio, o sistema pode entrar em colapso e os danos podem ser irreversíveis (GESAMP, 1982).

A poluição marinha é definida como sendo a introdução, direta ou indireta, de substâncias dentro do ambiente aquático, promovida por atividades humanas. Isso pode resultar em efeitos deletérios, como danos aos recursos vivos, à saúde humana e alteração da qualidade da água para qualquer uso (GESAMP, 1982).

Em ambientes costeiros como os manguezais, a ação dos poluentes fica acentuada, uma vez que estes elementos acabam permanecendo por muito tempo disponíveis para os organismos (KATHIRESAN \& BINGHAM, 2001). Além de ser um ambiente que funciona como quebra-mar, os manguezais servem como viveiro para muitas espécies de animais, cujos indivíduos têm sua sobrevivência aumentada pela proteção que a estrutura radicular dos mangues fornece contra ação de predadores (KATHIRESAN \& BINGHAM, 2001). A diversidade de espécies encontradas nos manguezais é muito grande e sua alta concentração de nutrientes e matéria orgânica contribuem para a produção primária das zonas litorâneas e ainda servem e alimento para muitas espécies (KATHIRESAN \& BINGHAM, 2001).

Nos manguezais, a baixa dinâmica e a grande quantidade de matéria orgânica favorece o acúmulo de metais. Os organismos presentes nesses ecossistemas, como crustáceos, moluscos e peixes, estão sujeitos a uma contaminação crônica, uma vez que mesmo em pequenas quantidades, os metais podem permanecer biodisponíveis por muito tempo (KATHIRESAN \& BINGHAM, 2001).

A exposição a concentrações moderadas de metais pode produzir uma variedade de efeitos em um organismo sem provocar sua morte imediata. Estes efeitos estão relacionados com alterações morfológicas, mudanças nos padrões fisiológicos e variações de comportamento (BRYAN, 1968). A observação de mudanças nos processos fisiológicos pode ser indicativa de uma alteração do ambiente. O balanço osmo-iônico, a taxa metabólica, as funções endócrinas, as respostas sensoriais e a atividade motora, entre outros, são processos que podem ser afetados por poluentes, refletindo a alteração da qualidade ambiental. Se a 
redução desta qualidade ambiental for crônica, as alterações fisiológicas podem afetar o crescimento e/ou reprodução dos indivíduos, alterando o sucesso populacional, podendo desequilibrar todo um ecossistema (BRYAN, 1968).

A ação dos metais pode ser detectada primeiramente nas superfícies da membrana celular, alterando suas características de permeabilidade (BOUQUEGNEU \& GILLES, 1979; HARRIS \& BAYLISS, 1988). Os metais podem atingir também o sistema enzimático, combinando-se por muitos caminhos com algumas enzimas formando quelantes e sais. Alguns estudos mostram que os metais inibem a atividade da $\mathrm{Na}^{+} / \mathrm{K}^{+}-\mathrm{ATPase}$ de brânquias, enzima esta vital ao processo de osmorregulação em animais aquáticos (BOUQUEGNEU \& GILLES, 1979; HARRIS \& BAYLISS, 1988; STAGG e col., 1992).

DEPLEDGE \& RAINBOW (1990) estudaram os mecanismos de regulação e acúmulo de metais em invertebrados marinhos e propuseram que após a entrada dos metais, via trato digestivo e através das superfícies corpóreas permeáveis, os metais essenciais podem ser acumulados em tecidos e posteriormente utilizados nos processos metabólicos, ou serem excretados. Para isso, o organismo necessita ter um mecanismo de destoxificação eficiente, onde os metais são transportados através da hemolinfa na forma dissolvida ou associados a proteínas, e então eliminados através dos órgãos excretores.

Alguns autores propõem modelos para explicar os mecanismos de assimilação e destoxificação dos metais em crustáceos. Uma das formas de eliminação dos efeitos tóxicos dos metais observada é através do acúmulo desses elementos no interior das células. Após a assimilação dos metais, esses podem se ligar a proteínas específicas, chamadas de metalotioneínas (MT), e os compostos formados por essa ligação (metal-MT) podem ser acumulados nos lisossomos, e então eliminados através dos órgãos excretores (GEORGE, 1990; DEPLEDGE \& RAINBOW, 1990; VIARENGO \& NOTT, 1993; PERDERSEN e col., 1998). Dessa forma o uso da metalotioneína como indicador de contaminação ambiental por metais vem sendo testado e tem se mostrado eficiente (MARTINEZ e col., 1993; PEDERSEN e col., 1996).

Parâmetros fisiológicos combinados com análises químicas de poluentes são ferramentas úteis utilizadas em estudos ecotoxicológicos e programas de monitoramento (WIDDOWS \& DONKIN, 1991; LUOMA, 1996). 


\section{Capítulo 1 - Efeito do cobre na osmorregulaçao do caranguejo de mangue Ucides cordatus}




\section{RESUMO}

A transição da vida aquática para a vida terrestre foi um evento presente em vários momentos da evolução. Um grande número de invertebrados ocupa nichos ecológicos na interface água

- terra e são capazes de se manter, pelo menos temporariamente, em ambos ambientes. 0 equilíbrio adequado de íons nos tecidos é de grande importância fisiológica. Elementos minerais, como sódio, potássio, magnésio e cálcio constituem fatores importantes na manutenção do equilíbrio ácido-base e do controle osmótico. Indivíduos machos de Ucides cordatus foram expostos a $5 \mathrm{mg} / \mathrm{L} \mathrm{CuSO}_{4}$ durante 24h, $96 \mathrm{~h}$ e 15 dias. Hemolinfa e urina foram retiradas para análise da concentração iônica de sódio, potássio, magnésio e cálcio, assim como para a análise da osmolalidade total destes fluidos. Houve variação da osmolaridade tanto na hemolinfa quanto na urina. Na comparação entre hemolinfa e urina, a osmolaridade foi similar durante $24 \mathrm{~h}$ e $96 \mathrm{~h}$ de exposição, enquanto que os valores obtidos para os grupos controle e grupo 15 dias de exposição foram opostos. O grupo controle apresentou maior valor de osmolaridade na hemolinfa, enquanto que para o grupo com 15 dias de exposição, a osmolaridade na urina foi maior. Quando os íons sódio, potássio, magnésio e cálcio foram analisados, uma dinâmica bastante diferente foi encontrada para cada um dos íons. Não houve diferença estatística entre os valores de concentração de potássio encontrados na urina como e hemolinfa. O mesmo ocorreu em relação aos valores de cálcio encontrados na urina do caranguejo. A concentração de sódio foi maior na hemolinfa, com redução da concentração no grupo com 15 dias de exposição ao cobre. Houve aumento gradativo das concentrações de sódio nos grupos com $24 \mathrm{~h}$ e $96 \mathrm{~h}$ de exposição, enquanto que na urina houve redução da concentração nos dois grupos do teste agudo, e o grupo com 15 dias de exposição apresentou reestabelecimento da concentração de sódio. Houve aumento gradativo da concentração de magnésio na hemolinfa em função do tempo de exposição ao metal, enquanto que na urina houve aumento até o grupo com 96h de exposição. Porém, houve redução da concentração de magnésio no grupo com 15 dias de exposição. A variação da osmolaridade parece estar associada ao tempo e à dose do metal utilizado, resultando na redução da habilidade da hemolinfa na regulação de diferentes íons. O oposto pode ocorrer no caso da urina dos caranguejos de mangue. Exposições de animais ao cobre na água frequentemente resultam numa redução da concentração de íons plasmáticos, como apresentado neste capítulo, e este efeito é geralmente atribuído a danos estruturais e funcionais em órgãos envolvidos na manutenção da homeostase em decorrência do acúmulo de cobre nesses órgãos.

Palavras-chave: Cálcio, magnésio, osmolalidade, potássio, sódio, Ucides cordatus. 


\section{ABSTRACT}

The transition from aquatic to terrestrial life was an event that was present in the various stages of evolution. A large number of invertebrates occupy ecological niches in the water-land interface, and they are able to survive, at least temporarily, in both environments. The proper balance of the various ions present in the tissues is of great physiological importance. Certain minerals like sodium, potassium, magnesium and calcium are key factors in maintaining the acid-base balance and osmotic control. Male individuals of Ucides cordatus were exposed to $5 \mathrm{mg} / \mathrm{L} \mathrm{CuSO}_{4}$ for $24 \mathrm{~h}, 96 \mathrm{~h}$ and 15 days and samples of haemolymph and urine were collected to determine the concentrations of sodium, potassium, magnesium and calcium, as well as the overall osmolality of these two fluids. There was variations in the osmolality of both haemolymph and urine. When the haemolymph and urine were compared, the osmolalities of both fluids were similar during $24 \mathrm{~h}$ and $96 \mathrm{~h}$ exposures, whereas the values obtained for the control and 15 days exposure groups were opposite, i.e. the control group showed a higher osmolality in the haemolymph, and in the 15 days exposure group the urine osmolality was higher. When sodium, potassium, magnesium and calcium were analyzed, a quite different dynamics for each of the ions was found. There was no statistical difference between urine and haemolymph with regards to potassium concentration values. The same trend was found with regards to calcium concentration values found in the crab urine. The sodium concentration was higher in the haemolymph than in the urine, with a reduction of sodium concentration in the group with 15 days exposure to copper. There was a gradual increase in the sodium concentration in the $24 \mathrm{~h}$ and $96 \mathrm{~h}$ exposure groups, while the sodium concentration in the urine decreased in both groups to which the acute test was applied, and in the 15 days exposure group the sodium concentration was back up again. The magnesium concentration values increased gradually in the haemolymph when the animals were exposed to copper, while in the urine it increased until the animals were exposed to 96 hours, but decreased after 15 days of exposure. The change in osmolality seems to be associated to the concentration of the metal and time of exposure, and this may result in a reduced ability of the haemolymph to regulate different electrolytes. The opposite may occur in the urine of the mangrove crab. Copper exposure in water often leads to a reduction in plasma ion concentrations such as those presented in this chapter, and this effect is commonly attributed to structural and functional damages involving homeostatic organs as a result of accumulation of copper in these organs.

Keywords: Calcium, magnesium, osmolality, potassium, sodium, Ucides cordatus. 


\section{INTRODUÇAO}

A transição da vida aquática para a vida terrestre foi um evento que esteve presente em vários momentos da evolução. Um grande número de invertebrados ocupa nichos ecológicos na interface água - terra e estes animais são capazes de se manter, ao menos temporariamente, em ambos ambientes (TRUCHOT, 1990). A água salobra é extremamente importante com implicações do ponto de vista fisiológico, pois representa uma barreira para a distribuição de muitos animais marinhos, assim como para animais de água doce, e também constitui uma transição interessante entre habitats marinhos e de água doce. Em dimensões geográficas, entretanto, a água salobra cobre menos de $1 \%$ da superfície terrestre (SCHIMIDTNIELSEN, 2002).

A manutenção de concentrações constantes de água e soluto varia com o meio e é completamente diferente na água do mar, na água doce e no ambiente terrestre. Portanto, os animais que vivem nesses diferentes ambientes apresentam mecanismos específicos de regulação capazes de manter concentrações constantes e apropriadas em um limite bastante estreito para garantir a sua sobrevivência. Ou seja, apresentam mecanismos de regulação que garantam a homeostase do organismo (SCHIMIDT - NIELSEN, 2002).

O equilíbrio ou balanço iônico nos tecidos é de grande importância fisiológica. Certos elementos minerais, como sódio e potássio, são importantes para a manutenção do equilíbrio ácido-base e da regulação osmótica. Por outro lado, outros minerais se encontram presentes em compostos de importância fisiológica, como o iodo na tiroxina, o ferro na hemoglobina e o cobre na hemocianina (HARPER e col., 1982). Assim como a relação entre cálcio e ferro é importante para uma ossificação normal, a relação entre potássio e cálcio no fluido extracelular também deve ser mantida para garantir a atividade normal do músculo. Assim, nos organismos de um modo geral, parece existir um balanço fino para a manutenção de elementos minerais principais e elementos traços essenciais. Todos os elementos essenciais são tóxicos quando sua ingestão é aumentada significativamente em relação às necessidades diárias da dieta, as quais são muito variáveis entre os diferentes organismos (HARPER e col., 1982).

Os íons metálicos alcalinos como magnésio, cálcio, sódio e potássio são importantes componentes estruturais e responsáveis por muitas funções fisiológicas, como a 
osmorregulação. Esses íons são principalmente provenientes da alimentação e da absorção, e esta, no caso de crustáceos, pode ocorrer através da superfície corporal de larvas e juvenis, devido à maior permeabilidade do exoesqueleto. Já nos indivíduos adultos, a absorção de íons metálicos ocorre durante o processo de muda e também durante todo o período de intermuda, com gasto de energia pelas brânquias (RAINBOW, 1988).

\section{OSMORREGULAÇÃO}

Durante a evolução, os organismos aquáticos e terrestres desenvolveram diversas estratégias para a manutenção do balanço de íons de metais provenientes do meio externo. As células selecionam os íons necessários para o seu desenvolvimento e excluem aqueles que não o são, e durante a vida adulta mantêm as concentrações iônicas em uma situação considerada ótima para cada animal diferentemente (PERALES-VELA e col., 2006). A história evolutiva dos crustáceos inclui uma radiação muito ampla do ambiente marinho para a água salobra e doce, assim como para o ambiente terrestre (LUCU \& TOWLE, 2003). A regulação da concentração total interna de soluto em um nível diferente daquele do meio externo é um pré-requisito para a invasão do ambiente terrestre (LUCU \& TOWLE, 2003). Um epitélio com capacidade osmorregulatória pode ocorrer em diferentes estágios do desenvolvimento e em diferentes locais, usualmente em órgãos da câmara branquial (LUCU \& TOWLE, 2003).

Os problemas associados à manutenção de concentrações internas constantes de água e soluto variam com o meio e são completamente diferentes na água do mar, água doce e ambiente terrestre (SCHIMIDT-NIELSEN, 2002). Os animais podem minimizar as dificuldades relacionadas com as diferenças de concentrações interna e externa por meio da redução da (i) permeabilidade e (ii) dos gradientes de concentração entre os fluidos corpóreos e o meio externo (SCHIMIDT-NIELSEN, 2002).

A salinidade é um dos principais fatores a exercer pressão seletiva nos organismos aquáticos. Seus níveis e variações têm impacto na composição da osmolaridade dos fluidos corporais dos animais e as espécies que são capazes de osmorregular de maneira eficaz são geralmente eurialinas (LUCU e col., 2000). 
Muitos dos crustáceos marinhos são essencialmente isosmóticos em relação ao meio marinho e empregam íons de sódio e cloreto como osmólitos primários da hemolinfa (LUCU, 1990). Espécies eurialinas, no entanto, invadem águas estuarinas, utilizando mecanismos branquiais de bombeamento iônico para compensar a perda iônica por difusão, para então manter o equilíbrio osmótico (MASUI e col., 2005). Crustáceos hiperosmorreguladores, distribuídos nos estuários, regulam a concentração de seus fluidos extracelulares, os quais, por sua vez, protegem o espaço intracelular de mudanças osmóticas drásticas (LUCU e col., 2000).

A cutícula, a qual recobre as brânquias e o epitélio do epipodito, é considerada como uma barreira seletiva para o movimento catiônico e aniônico. Tal seletividade é mais expressa em crustáceos hiperosmorreguladores, como o caranguejo Eriocheir sp e Carcinus sp, e menos expressa em osmoconformadores, como o caranguejo Maja squinado e o lagostim Nephrops novergicus (LUCU e col., 2000). Alguns crustáceos podem, ainda, alterar a permeabilidade em resposta à redução de salinidade e, talvez deste modo, alterar, a tomada de metais (RAINBOW, 2000). As células epiteliais das brânquias, hepatopâncreas, glândula antenal e tegumento dos crustáceos controlam os movimentos de cátions e ânions entre a hemolinfa e o meio ambiente, e ao fazê-lo regulam a atividade iônica e osmótica, a acidificação gástrica, a ecdise e a destoxificação de metais (MARTINEZ e col., 1999).

Durante o processo evolutivo, para alguns grupos taxonômicos, ocorreu aumento da independência de flutuações existentes no ambiente externo. Tal adaptação se deu por meio de uma diminuição da permeabilidade da superfície corpórea à água ou solutos, restrições na taxa de influxo e perda de íons e incremento da habilidade da tomada de iônica através do ajuste das funções de transporte iônico para as células do animal (LUCU \& TOWLE, 2003). 


\section{Sódio}

Este elemento é, quantitativamente, o principal cátion do fluido extracelular, e se encontra associado, em grande parte, à íons cloreto e bicarbonato na regulação do equilíbrio ácido-base. A outra função importante do sódio é a manutenção da pressão osmótica dos líquidos corporais, protegendo desse modo o organismo contra a perda excessiva de líquido. Funciona também na preservação da irritabilidade normal dos músculos e da permeabilidade celular (HARPER e col., 1982).

A ingestão diária recomendada para seres humanos é a de 1,5 g e a principal fonte de sódio é o cloreto de sódio usado com freqüência no cozimento e tempero dos alimentos, entre eles, pães, queijos, mariscos, ostras, biscoitos, grãos integrais e muitos outros (HARPER e col., 1982).

\section{Potássio}

Apesar de o sódio ser normalmente o principal cátion no sangue e fluidos extracelulares, o potássio é o cátion dominante no espaço intracelular, onde a concentração de sódio é correspondentemente mais baixa (SCHIMIDT-NIELSEN, 2002). O potássio possui entre uma de suas principais funções a troca e o transporte de outros íons para os meios intra e extracelular (SCHIMIDT-NIELSEN, 2002).

Como mencionado, o potássio é o principal cátion do fluido intracelular. Porém, devido à sua influência na atividade muscular, principalmente na do músculo cardíaco, é também um constituinte muito importante do fluido extracelular. No interior das células, e do mesmo modo que o sódio no fluido extracelular, o potássio influencia o equilíbrio ácido-base e a pressão osmótica, incluindo a retenção hídrica. Concentrações elevadas do potássio intracelular são essenciais para várias funções metabólicas importantes, incluindo a biossíntese de proteínas pelos ribossomos e a atividade de inúmeras enzimas, como, por exemplo, a piruvato-quinase, a qual requer potássio para sua atividade máxima (HARPER e col., 1982). A ingestão diária recomendada de potássio é de 4,5 g em seres humanos (HARPER e col., 1982). 


\section{Magnésio}

O organismo dos seres humanos contém cerca de $21 \mathrm{~g}$ de magnésio e $70 \%$ destes $21 \mathrm{~g}$ estão complexados com o cálcio e o fósforo nos sais complexos presentes nos ossos, e o restante se encontra nos tecidos moles e nos fluidos corporais (HARPER e col., 1982). A deficiência de magnésio no homem induz disfunção neuromuscular, manifestada por hiperexcitabilidade com tremores e convulsões, e pode estar acompanhada, em alguns casos, de distúrbios de comportamento. A ocorrência generalizada de magnésio nos alimentos torna a possibilidade de uma deficiência, sob condições normais, em extremamente rara e a dose diária recomendada é de 240 mg para o homem (HARPER e col., 1982).

O magnésio é encontrado em derivados do cacau, várias nozes, soja e alguns frutos do mar, além de grãos integrais. $O$ terceiro íon presente em maior concentração nos organismos é o magnésio, que exerce importantes funções fisiológicas como a de cofator enzimático e a de modulador da hemocianina, além de estar presente na junção neuromuscular dos crustáceos (HARPER e col., 1982). Segundo MORRIT \& SPICER (1993), o magnésio apresenta efeito sinergético junto com o íon cálcio na hemolinfa, reduzindo a afinidade do oxigênio à hemocianina.

\section{Cálcio}

O íon cálcio é necessário na manutenção das funções normais das células, condução nervosa, contração muscular e coagulação sanguínea, além de ser um importante elemento dos esqueletos e muitas outras estruturas mecânicas rígidas (SCHIMIDT-NIELSEN, 2002).

O cálcio é um íon divalente, que faz parte da composição básica da maioria dos animais, sendo importante na constituição e fortalecimento de tecidos rijos, na regulação das contrações musculares e na sinalização intracelular (HARPER e col., 1982).

Cerca dos $99 \%$ do cálcio do organismo se encontram no esqueleto e correspondem aos depósitos de fosfatos de cálcio impregnados em uma matriz fibrosa e mole. A pequena quantidade de cálcio presente além das estruturas ósseas, encontra-se em parte ionizado nos fluidos do organismo. Na verdade, essa pequena quantidade de cálcio ionizado nos fluidos do corpo é de grande importância na coagulação do sangue, na manutenção da excitabilidade normal do coração, músculos e nervos, e na permeabilidade das membranas (HARPER e col., 1982). Além das funções supracitadas, o cálcio é de primordial importância para os crustáceos 
porque cristais de carbonato de cálcio $\left(\mathrm{CaCO}_{3}\right)$ são ser depositados no novo exoesqueleto para que ocorra o seu enrijecimento após a ecdise (troca de exoesqueleto) (ZANOTTO e col., 2004).

Metais podem interagir com grupos SH (sulfidrila) e participar da liberação de cálcio do retículo sarcoplasmático e vesículas hepáticas. Sugere-se que a indução da liberação de cálcio por metais é devido à interação entre o metal e o cálcio com consequente alteração da proteína que contém este grupo SH e dessa maneira, os metais servem como ferramenta útil para a sondagem de mecanismos de liberação de cálcio (YAMAGUCHI, 1993).

Entre os alimentos comuns, o leite e o queijo são, sem dúvida, as fontes mais ricas de cálcio. A maioria dos outros alimentos contribui com pequenas quantidades: como gema de ovo, feijão, lentilha, nozes, figos, couve-flor e aspargos, que são alguns exemplos (HARPER e col., 1982). 


\section{OBJETIVOS}

\section{Geral}

O presente estudo tem como objetivo principal investigar a ocorrência de efeitos da exposição do caranguejo de mangue Ucides cordatus ao cobre presente na água, sob a forma de $\mathrm{CuSO}_{4}$, sobre a capacidade osmorregulatória destes animais e sobre a concentração específica de alguns íons.

Como a regulação da capacidade osmorregulatória do caranguejo através do balanço iônico específico é essencial para a completa inserção deste animal no ambiente estuarino, que é extremamente variável ao longo do dia e de acordo com a maré, faz-se necessária a determinação e caracterização dos efeitos provenientes da exposição ao cobre, uma vez que o habitat destes animais é constantemente alvo de despejo e consequentemente poluído por metais e poluentes dos mais variados.

\section{Específicos}

Para a determinação do possível efeito do cobre no balanço osmorregulatório do caranguejo de mangue Ucides cordatus, determinou-se:

- a osmolalidade total das amostras da urina e hemolinfa de caranguejos expostos ao cobre na água;

- a concentração de sódio, potássio, magnésio e cálcio na hemolinfa e urina dos caranguejos expostos ao cobre na água para eventual contraposição com os dados obtidos de cada um dos osmólitos supracitados, já que estes são íons essenciais para o balanço osmótico dos fluidos dos animais, embora tanto hemolinfa quanto urina sejam compostas por outros íons e moléculas variados. 


\section{PARTE EXPERIMENTAL}




\section{MATERIAL E METODOS}

\section{Animais}

Neste estudo, utilizou-se 40 machos de Ucides cordatus, com massa corpórea média de ordem de 156,00 \pm 4,61 g, coletados no estuário próximo à Praia dos Pescadores, Itanhaém, Sul do Estado de São Paulo, Brasil. A Estância Balneária de Itanhaém compreende uma área de $597,4 \mathrm{~km}^{2}, 46047^{\prime} 15^{\prime \prime}$ Oeste e 24 11' 08' Sul, e está situada num ecossistema, o mangue, que consiste na transição entre terra e mar, tipicamente encontrado em regiões tropicais e subtropicais.

Após a coleta, os caranguejos foram aclimatados no Biotério da Universidade Presbiteriana Mackenzie durante sete dias em água do mar em salinidade 20\%, 12C:12E, $25 \pm$ $1^{\circ} \mathrm{C}$, e alimentados com alface e carne moída em dias alternados. Somente após o período de aclimatação, os experimentos com a presença de cobre na água foram realizados.

\section{Experimentos}

Os 40 caranguejos machos foram aleatoriamente divididos em quatro grupos (Controle, 24h, 96h e 15 dias de exposição ao cobre na água) e, antes de serem colocados em aquários de $15 \mathrm{~L}$ com paredes encapadas de preto, os animais foram pesados em balança Denver Instrument Company TR-402, bem como logo após o término de cada experimento, para haver controle da massa dos indivíduos ao término dos experimentos realizados com cada grupo experimental.

Em cada aquário de $15 \mathrm{~L}$ foram colocados $5 \mathrm{~L}$ de água do mar $20 \%$ o para que os animais não ficassem cobertos de água (sendo este mais um fator de estresse evitado) e para não impedir a sua rotina diária de imersão e emersão. A troca de água foi feita diariamente, com a adição de $5 \mathrm{mg} / \mathrm{L} \mathrm{CuSO}_{4}$ para obter $2 \mathrm{mg} / \mathrm{L}$ cobre, a fim de garantir a mesma exposição de cobre à todos os animais com aeração constante para todos os aquários. 
Ao final dos experimentos e de acordo com seus respectivos intervalos de tempo (24h, $96 \mathrm{~h}$ e 15 dias), os animais foram crio-anestesiados para dessensibilização durante 15 a 20 minutos em freezer comum. Alíquotas de hemolinfa e urina foram retiradas, com seringas inseridas no último pereiópodo e no pedúnculo ocular, respectivamente. Após a retirada dos fluidos supramencionados, os animais foram sacrificados por meio da separação manual das partes dorsal e ventral, e, em seguida, retirou-se alíquotas de brânquias, hepatopâncreas e músculo da quela, para demais experimentos que serão citados nos capítulos subsequentes.

As alíquotas de hemolinfa e urina foram utilizadas diretamente e sem prévio processamento para a determinação da osmolalidade. Para tal, utilizou-se $10 \mu \mathrm{L}$ de cada amostra para as medições em osmômetro Vapro (Wescor) vapor pressure osmometer 5520, com valores expressos em mmol/Kg. Os valores de osmolalidade obtidos consistem na média de três leituras com duração de um minuto cada.

Após a determinação da osmolalidade total de cada amostra de urina e hemolinfa, foram determinadas as concentrações de sódio, potássio, magnésio e cálcio com o auxílio de um espectrofotômetro de chama, no Laboratório de Caracterização e Processamento de Materiais da Universidade Mackenzie. Para cada íon, foi utilizado um protocolo de preparo das amostras, como apresentado na tabela a seguir:

Tabela 1: Protocolo de preparo das amostras de hemolinfa e urina do caranguejo de mangue Ucides cordatus para determinação da concentração de cálcio, magnésio, potássio e sódio em espectrofotômetro de chama.

\begin{tabular}{lllll}
\hline Íon & Amostra & Solução & Água MilliQ & Diluição Final \\
\hline $\begin{array}{l}\text { Cálcio } \\
\text { Magnésio }\end{array}$ & $10 \mu \mathrm{L}$ & $\begin{array}{l}5 \mathrm{~mL} \text { Cloreto de } \\
\text { Lantâneo 0,2\% }\end{array}$ & $5 \mathrm{~mL}$ & $1001 \times$ \\
$\begin{array}{l}\text { Potássio } \\
\text { Sódio }\end{array}$ & $10 \mu \mathrm{L}$ & $\begin{array}{l}5 \mathrm{~mL} \text { Cloreto de } \\
\text { Césio 0,2\% }\end{array}$ & $5 \mathrm{~mL}$ & $1001 \times$ \\
& $\begin{array}{l}1 \mathrm{~mL} \text { da solução } \\
\text { para } \\
\text { determinação } \\
\text { de } \mathrm{K}^{+}\end{array}$ & $\begin{array}{l}5 \mathrm{~mL} \text { Cloreto de } \\
\text { Césio 0,2\% }\end{array}$ & $19 \mathrm{~mL}$ & $25001 \times$ \\
\hline
\end{tabular}




\section{Análise dos Dados}

Todos os resultados foram plotados utilizando o programa Prism Graph Pad 5 (Graph Pad Software Inc, La Jolla, CA, EUA) e analisados com o programa Sigma Stat 3.1.

Aplicou-se num primeiro momento o teste de análise de variância (ANOVA) para todos os resultados obtidos e após o teste de normalidade dos resultados, foram aplicados os testes Kruskal-Wallis seguido pelo teste de Dunn's para os seguintes dados obtidos: osmolalidade de hemolinfa e urina, bem como para os dados da concentração de sódio e cálcio da hemolinfa dos caranguejos, já que o teste de normalidade dos dados falhou.

Para os dados da concentração de sódio na urina e magnésio em ambos os fluidos, aplicou-se o teste Holm-Sidak após o teste ANOVA, uma vez que o teste para normalidade foi realizado com sucesso. Já para os dados obtidos para a concentração de potássio em hemolinfa e urina, bem como a concentração e cálcio na urina, foi somente realizado teste de análise de variância devido à não verificação de diferença estatística significativa. 
RESULTADOS

A figura 1 apresenta os valores de osmolalidade em amostras de hemolinfa e urina e é possível observar que houve bastante variação entre os dias de exposição. Os valores apresentados para a hemolinfa tendem a aumentar no primeiro contato com o ambiente hostil (durante as primeiras $24 \mathrm{~h}$ de exposição), porém não é observada diferença estatística com o grupo controle $(p>0,05)$ e com o passar do tempo tais valores decaem e assim nota-se diferença estatística com $\mathrm{p}<0,05$ para a comparação entre grupos $24 \mathrm{~h}$ e $96 \mathrm{~h}$ e $24 \mathrm{~h}$ com grupo de 15 dias de exposição, embora os grupos 96h e 15 dias não tenham apresentado diferença estatística significativa em relação ao grupo controle.

Já para as amostras de urina, houve maior variação, onde os grupos $24 \mathrm{~h}$ e 15 dias apresentam valores superiores ao do controle, ambos com $p<0,05$, enquanto que os valores de osmolalidade para o grupo $96 \mathrm{~h}$ foi somente diferente estatisticamente do grupo $24 \mathrm{~h}$, o qual apresentou maior variação da osmolaridade em relação ao grupo controle.

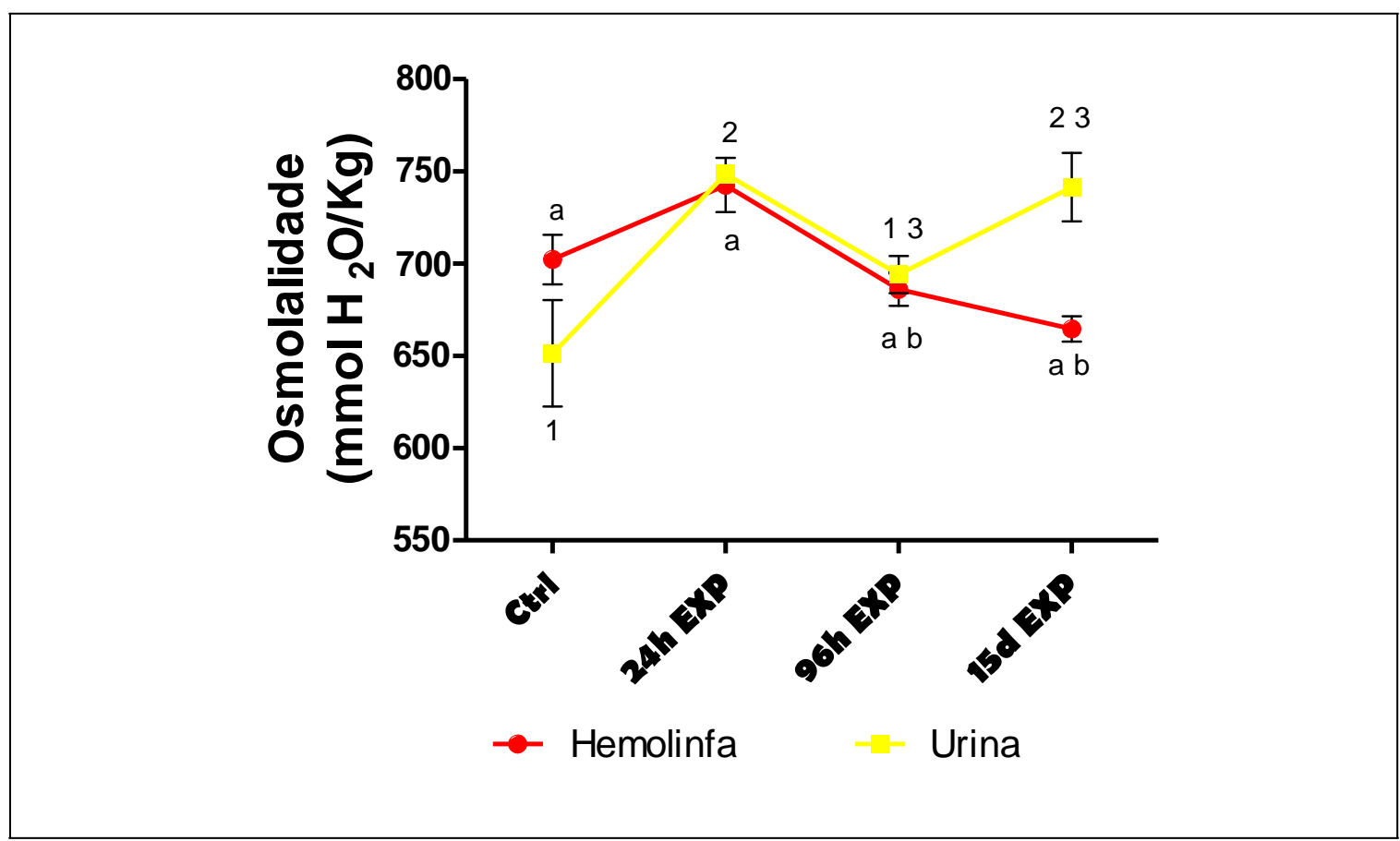

Figura 1: Determinação da osmolalidade (mmol $\mathrm{H}_{2} \mathrm{O} / \mathrm{Kg}$ ) em amostras de hemolinfa e urina do caranguejo de mangue Ucides cordatus na condição controle e quando submetidos a testes agudo (24h e 96h) e crônico (15 dias) de exposição à $5 \mathrm{mg} / \mathrm{L} \mathrm{CuSO}_{4}, \mathrm{n}=10$. 
A figura 2 apresenta os valores obtidos da concentração de sódio em hemolinfa e urina e é possível observar que tais valores são inversamente proporcionais nos dois fluidos, ou seja, quando os valores de sódio são reduzidos na hemolinfa, há aumento na excreção através da urina e o inverso é verdadeiro. Porém, quando analisados os valores de sódio na hemolinfa, nota-se que houve diferença estatística quando comparados os dois grupos do teste agudo, 24h e 96h, com p<0,05 e também comparando os grupos 96h e 15 dias com p<0,05, onde após aumento considerável da concentração de sódio na hemolinfa do grupo 96h, houve redução próxima dos valores do grupo controle, quando não foi encontrada diferença estatística.

A concentração de sódio na urina foi, para todos os grupos, inferior aos valores encontrados para hemolinfa em todos os grupos e obteve $p<0,05$ somente para comparação dos grupos $24 \mathrm{~h}$ e $96 \mathrm{~h}$, assim como para a hemolinfa.

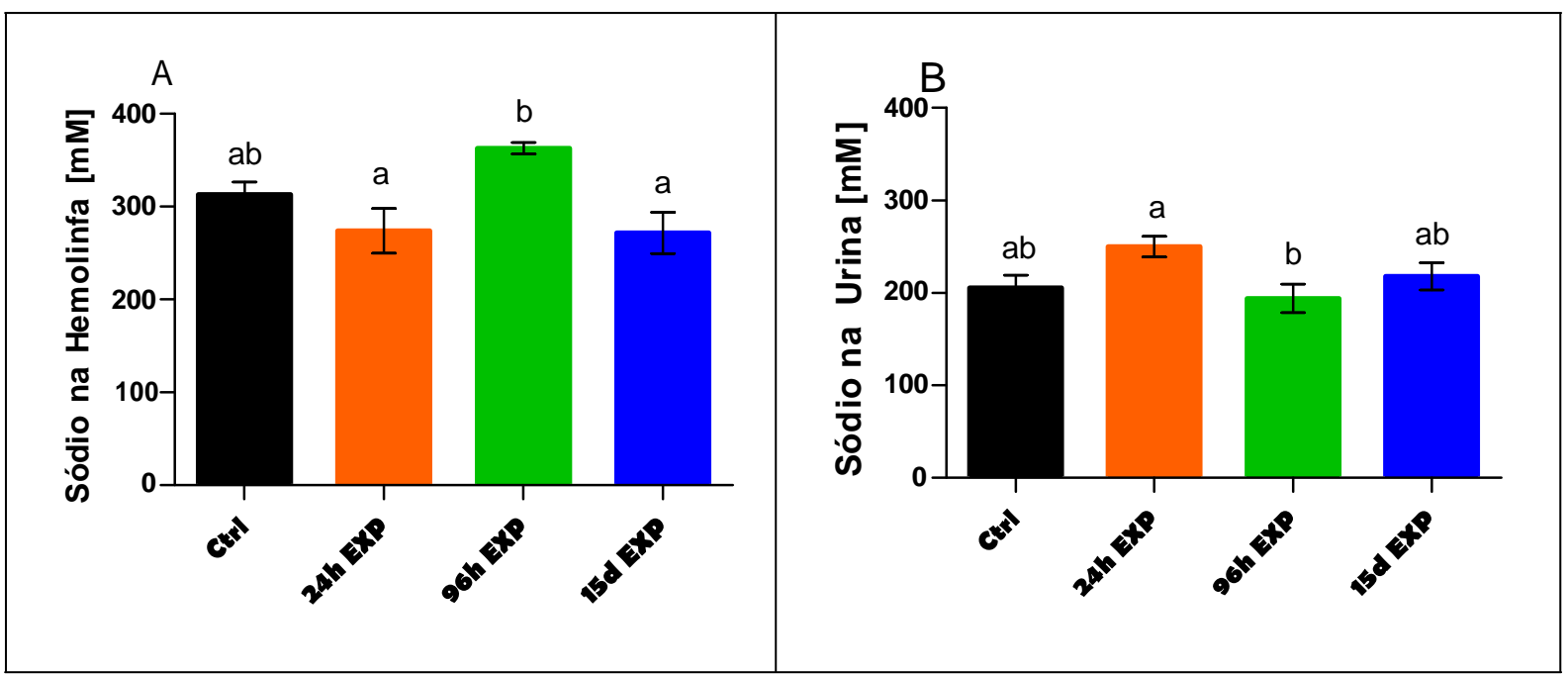

Figura 2: Determinação da concentração de sódio $(\mathrm{mM})$ em amostras de hemolinfa $(A)$ e urina (B) do caranguejo de mangue Ucides cordatus na condição controle e quando submetidos a testes agudo (24h e 96h) e crônico (15 dias) de exposição à $5 \mathrm{mg} / \mathrm{L} \mathrm{CuSO}_{4}, \mathrm{n}=10$. 
A figura 3 apresenta os valores obtidos para a concentração de potássio apresentando baixa variação entre grupos experimentais e controle, não havendo diferença estatística entre si, quando analisados os valores para hemolinfa. Resultados similares foram observados para urina, porém o grupo 15 dias de exposição ao cobre apresentou tendência da redução dos níveis de potássio na urina, mesmo não havendo diferença estatística significativa entre os grupos comparados (controle e experimentais). Nota-se também que os valores de potássio na urina são relativamente maiores do que os da hemolinfa, indicando possível eliminação do excesso deste íon.

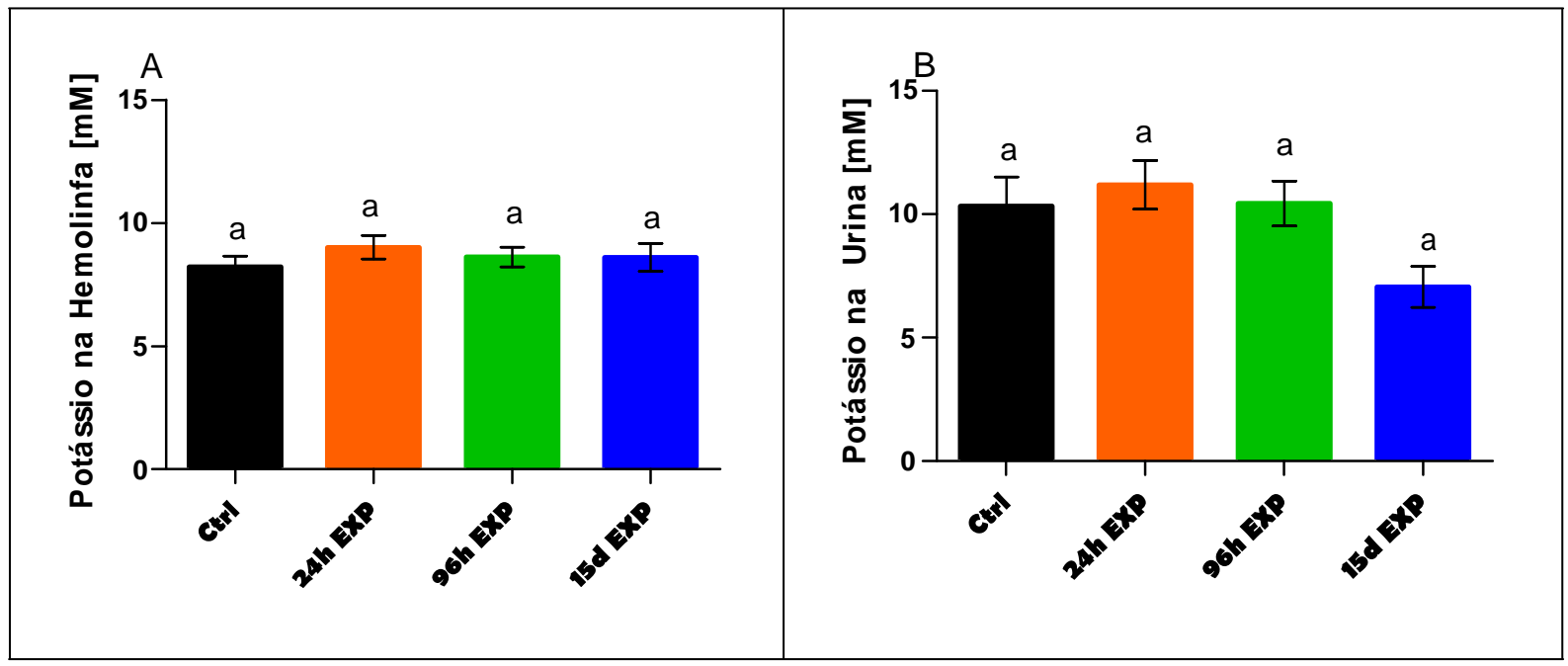

Figura 3: Determinação da concentração de potássio (mM) em amostras de hemolinfa (A) e urina (B) do caranguejo de mangue Ucides cordatus na condição controle e quando submetidos a testes agudo (24h e $96 \mathrm{~h}$ ) e crônico (15 dias) de exposição à $5 \mathrm{mg} / \mathrm{L} \mathrm{CuSO}_{4}, \mathrm{n}=10$. 
A figura 4 apresenta os valores da concentração de magnésio na hemolinfa e urina do caranguejo Ucides cordatus e observa-se que, para hemolinfa, houve aumento da concentração deste cátion proporcionalmente ao aumento do tempo de exposição, obtendose valor de $p<0,05$ para todos os efeitos de comparação em relação ao grupo controle. Já quando comparados os dois grupos de teste agudo (24h e 96h) não houve diferença estatística significativa, com $p>0,05$.

O mesmo resultado para a comparação entre grupos experimentais e controle foi observado para as amostras de urina, com $p<0,05$, porém quando comparados os valores obtidos para os grupos $24 \mathrm{~h}$ e 15 dias de exposição obteve-se $p>0,05$, embora ambos tenham sido superiores ao grupo controle e diferente estatisticamente ao grupo controle $(p<0,05)$.

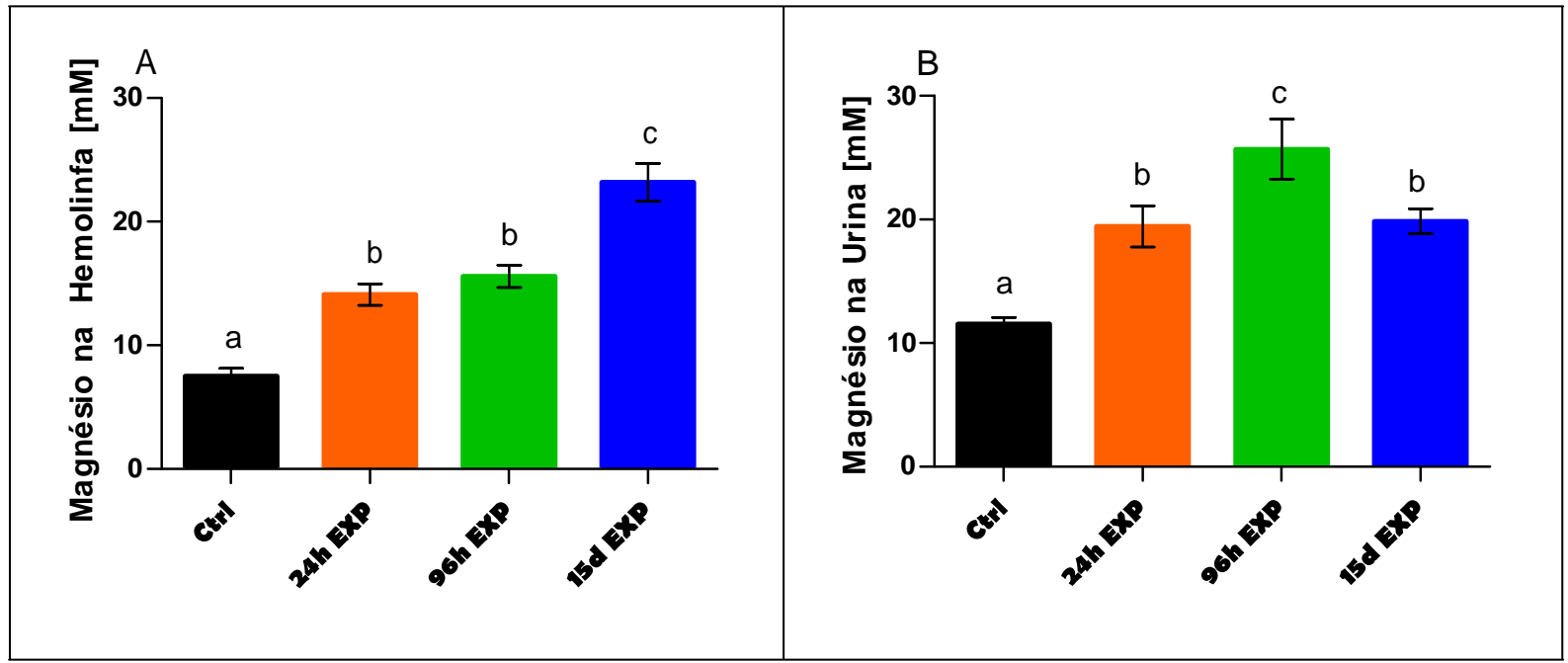

Figura 4: Determinação da concentração de magnésio (mM) em amostras de hemolinfa (A) e urina (B) do caranguejo de mangue Ucides cordatus na condição controle e quando submetidos a testes agudo (24h e 96h) e crônico (15 dias) de exposição à $5 \mathrm{mg} / \mathrm{L} \mathrm{CuSO}_{4}, \mathrm{n}=10$. 
A figura 5 apresenta os resultados da concentração de cálcio nas amostras de hemolinfa e urina e são valores bastante distintos entre si, onde, para as amostras de hemolinfa houve constância na concentração deste cátion entre grupos controle e os dois grupos do teste agudo ( $24 \mathrm{~h}$ e $96 \mathrm{~h}$ ), onde somente foi observada diferença estatística entre controle e grupo exposto durante $96 \mathrm{~h}$ ao cobre na água com $p<0,05$, enquanto que quando comparado com o grupo $24 \mathrm{~h}$ não houve diferença estatística, com p>0,05 e o mesmo foi observado quando comparados os dois grupos componentes do teste agudo ( $24 \mathrm{~h}$ e $96 \mathrm{~h}$ ). Já quando se observa o grupo exposto durante 15 dias, é nítido o aumento da concentração de cálcio na hemolinfa, com valores de $p<0,05$ para comparação com grupo controle e $24 \mathrm{~h}$ de exposição, enquanto que para o grupo 96h não houve tal diferença estatística.

Ao contrário do que foi observado para a concentração de cálcio na hemolinfa, não houve diferença estatística entre grupos controle e experimentais em relação às amostras de urina, onde foi obtido para todos os efeitos de comparação, p>0,05.

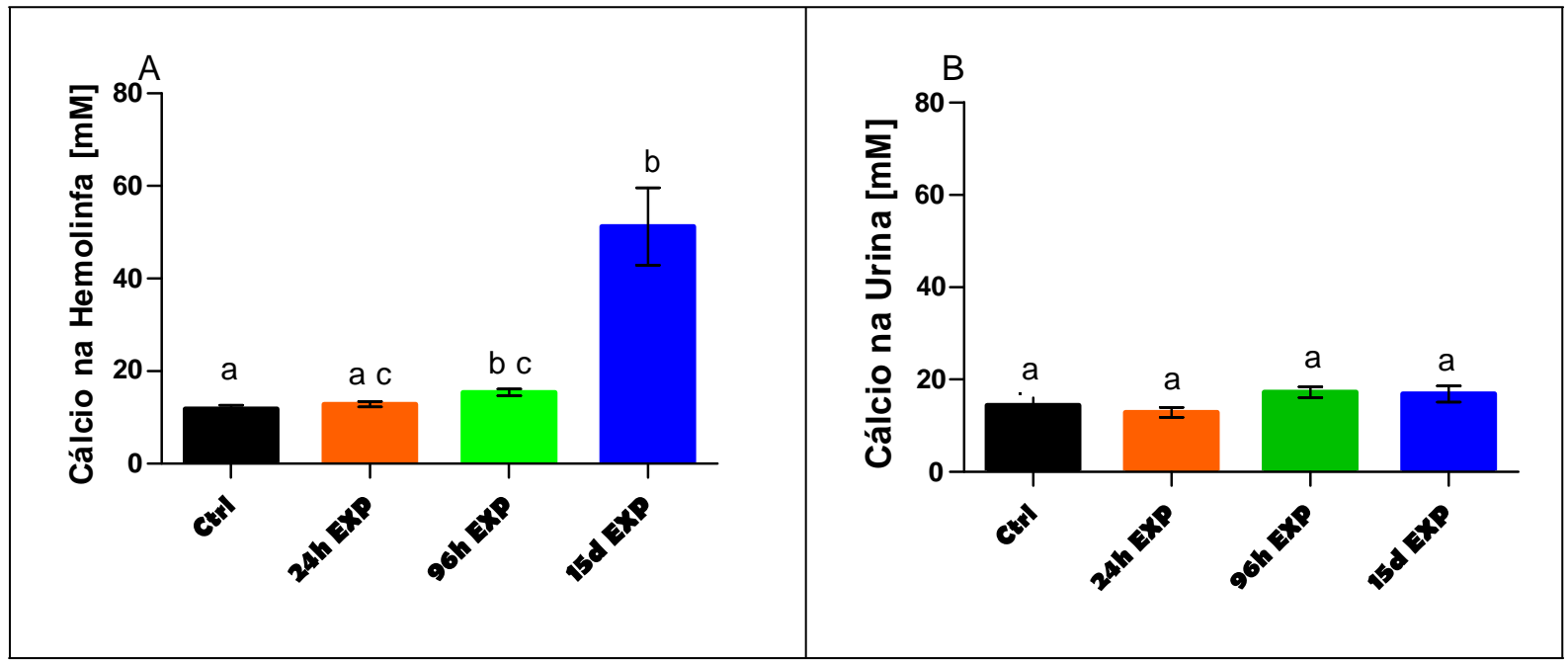

Figura 5: Determinação da concentração de cálcio (mM) em amostras de hemolinfa (A) e urina (B) do caranguejo de mangue Ucides cordatus na condição controle e quando submetidos a testes agudo (24h e $96 \mathrm{~h}$ ) e crônico (15 dias) de exposição à $5 \mathrm{mg} / \mathrm{L} \mathrm{CuSO}_{4}, \mathrm{n}=10$. 


\section{DISCUSSAO}

Animais que habitam áreas cronicamente poluídas devem fazer ajustes fisiológicos para se defender dos efeitos de metais a fim de manter a sua homeostase, e existem evidências de que os sistemas fisiológicos podem desenvolver resistência a metais (HARRIS \& SANTOS, 2000). Alguns estudos têm revelado que altas concentrações de metais induzem respostas osmorregulatórias e respiratórias nos crustáceos em geral (SPICER \& WEBER, 1991; LAWSON e col., 1995).

\section{Osmorregulação}

MONTEIRO e col. (2005) demonstraram que a osmolalidade plasmática da tilápia do Nilo (Oreochromis nilocatus) se altera em função do tempo e da dose de metal. Exposições a crescentes concentrações de cobre $\left(250,500 \mu \mathrm{g} \mathrm{Cu}^{2+} / \mathrm{L}\right.$ e $\left.1 \mathrm{mg} \mathrm{Cu}{ }^{2+} / \mathrm{L}\right)$ estão também associadas a uma redução da concentração de hemocianina na hemolinfa (BJERREGAARD \& VISLIE, 1986) e a explicação para isto é um aumento do volume da hemolinfa, em vez de uma alteração na concentração de hemocianina (DEPLEDGE \& BJERREGAARD, 1989), possivelmente ligado a alterações da permeabilidade à água (RASMUSSEN e col., 1995; HEBEL e col., 1997).

A exposição de caranguejos a uma água com altas concentrações de cobre resulta na redução da habilidade da hemolinfa em regular a sua própria concentração, causando, no caso dos peneídos, por exemplo, uma perda da habilidade destes crustáceos de hipo ou hiperregular e/ou osmorregular, enquanto que o cádmio age como um fator que permite a elevação da concentração iônica da hemolinfa (HARRIS \& SANTOS, 2000).

A perda do controle osmótico pode causar a morte de trutas expostas a soluções altamente letais de sulfato de zinco e isso ocorre porque as mudanças nas concentrações osmóticas do sangue se dão de modo muito rápido, dificultando a manutenção dos níveis normais. Por outro lado, pequenas alterações das concentrações de sódio, potássio, cálcio, magnésio e zinco no sangue são improváveis de causar desbalanço fisiológico, embora alterações locais no tecido branquial podem acarretar prejuízos às brânquias e até mesmo a perda de função vital (LI e col., 1998). Para manter a homeostase, durante exposição ao cobre, 
os peixes ativam uma série de processos bioquímicos e fisiológicos, cujo resultado é destoxificar e reestabelecer o "maquinário" de tomada de íons pelas brânquias (LI e col., 1998) e um mecanismo similar pode ser sugerido para os crustáceos.

\section{Íons}

Os animais que vivem em ambientes sujeitos a variações de salinidade como nos estuários, adaptaram-se para utilizar mecanismos de compensação para acomodar os choques osmóticos provenientes do meio externo (HARRIS \& SANTOS, 2000). A função principal das glândulas antenais é a de regular o volume dos fluidos corpóreos e, através da urina formada, eliminar solutos orgânicos e inorgânicos, dentre estes, mais especificamente, íons divalentes, como magnésio e cálcio (PEQUEUX, 1995). Ucides cordatus, por exemplo, excreta magnésio e potássio através de sua urina e reabsorve sódio (SANTOS \& SALOMÃO, 1985; HARRIS \& SANTOS, 2000).

A concentração osmótica da hemolinfa pode ser modificada devido à perda da habilidade osmorregulatória provocada pelos metais. Segundo a literatura, a concentração osmótica da hemolinfa normalmente diminui nos animais expostos ao cobre. Porém, não existe um padrão de ação deste poluente sobre a concentração osmótica da hemolinfa e cada animal pode responder de forma diferente quando submetido a esse estresse, variando conforme a espécie observada, a concentração e a forma química do metal utilizado (BOUQUEGNEAU \& GILLES, 1979; HARRIS \& BAYLISS, 1988; HANSEN e col., 1992; STAGG e col., 1992). A exposição prévia ao cobre parece ter eliminado a capacidade de Ucides cordatus em formar uma urina mais diluída em relação ao sódio, podendo ser um indicativo de alguma alteração fisiológica promovida pela exposição prévia a este metal (HARRIS \& SANTOS, 2000).

A desidratação pode afetar significativamente o balanço iônico e os caranguejos de mangue se encontram fisiologicamente adaptados para resistir a grandes alterações desta natureza. Em Ucides cordatus e Carcinus maenas, o efluxo total de sódio é reduzido consideravelmente durante a emersão e a redução na perda de água e íons resulta da redução do volume da urina (KATHIRESAN \& BINGHAM, 2001).

A exposição de peixes ao cobre presente na água frequentemente leva a uma redução na concentração de íons plasmáticos, particularmente sódio e potássio. Este efeito é geralmente atribuído a danos estruturais e funcionais das brânquias como resultado do acúmulo de cobre 
neste órgão (Li e col., 1998). Sódio e cloreto são os maiores efetores osmóticos da hemolinfa de Neohelice granulata e suas concentrações são mantidas em equilíbrio eletroquímico em meio diluído (CASTILHO e col., 2001) para balanço osmorregulatório.

$\mathrm{Na}$ truta arco-íris Salmo gairdneri, as perdas de íons sódio para o meio externo aumentaram na presença do cobre em indivíduos expostos ao metal durante $24 \mathrm{~h}$ e $96 \mathrm{~h}$ (LAUREN \& McDONALD, 1985). Os dados obtidos no presente estudo, em Ucides cordatus, corroboram aqueles obtidos por MONTEIRO e col. (2005). Isto é, ocorre uma redução da concentração de sódio na hemolinfa em função do tempo de exposição, já que o grupo exposto ao cobre durante 15 dias apresentou uma redução da concentração de sódio na hemolinfa assim como na urina.

Tem sido demonstrado para diversas espécies que a toxicidade aguda do cobre é resultado da competição entre cobre e sódio por um único sítio de ligação no canal apical de sódio, impedindo a regulação do transporte deste íon e inibindo a sua tomada ativa. Em peixes de água doce, a exposição ao cobre claramente resulta em um rápido acúmulo do metal nas brânquias, seguido de distúrbio da homeostase, especialmente no que diz respeito aos íons sódio e cloreto (GROSELL e col., 2004).

Quando há presença de cobre na água, pode haver um aumento de sódio e cloreto no plasma, resultando no aumento da osmolalidade plasmática. Quanto mais extrema for a elevação da osmolaridade do plasma, maior será a perda de fluido do tecido muscular branco (GROSELL e col., 2004). A redução da concentração de sódio na hemolinfa de animais expostos ao cobre pode acontecer, simplesmente, devido a danos provocados à integridade estrutural das brânquias, tornando-as mais permeáveis (porosas), como, por exemplo, em decorrência da separação das junções entre as células epiteliais das brânquias (BROOKS \& MILLS, 2003).

LAUREN \& MCDONALD, em 1985, em estudo realizado com a truta Salmo gairdneri, observaram que ao mesmo tempo em que houve perda de íons sódio para o meio externo, houve também perda de íons potássio na presença de cobre. Porém, no presente estudo com Ucides cordatus, tal perda não foi observada, sugerindo que o tempo de exposição e a concentração de $\mathrm{CuSO}_{4}$ não tenham sido suficientes para causar nítida alteração da concentração do íon potássio.

Um aspecto interessante em relação ao nível plasmático de magnésio é observado em alguns crustáceos. Aqueles que são muito ativos e possuem capacidade de movimentação rápida, como, por exemplo, os caranguejos dos gêneros Pachygrapsus sp e Neophrops sp, 
apresentam baixos níveis de magnésio, ao passo que aqueles de movimentação lenta, como o caranguejo aranha do gênero Maia, apresentam altas concentrações de magnésio. O magnésio é um agente anestésico que deprime a transmissão de impulsos nervosos na musculatura e, num primeiro momento, pode-se sugerir que uma alta concentração de magnésio esteja relacionada ao baixo nível de atividade de alguns crustáceos. Entretanto, a observação complementar de que o molusco do gênero Sepia, o qual se movimenta de maneira rápida além de nadar muito bem, possui uma concentração de magnésio tão alta quanto à do bivalve Pecten, levanta suspeitas sobre a existência de uma correlação de causa e efeito entre atividade física e concentração de magnésio (SCHIMIDT-NIELSEN, 2002).

No presente capítulo, os resultados apresentados para a concentração de cálcio, são bastante contrastantes com os existentes na literatura, uma vez que somente houve diferença estatística na concentração de cálcio da hemolinfa dos caranguejos expostos durante 15 dias ao cobre. Em razão deste resultado, é possível sugerir que a presença do cobre na forma de sulfato tenha causado um aumento considerável dos valores de $\mathrm{pH}$ da hemolinfa desses animais, causando, por sua vez, um certo tamponamento deste fluido. Os resultados são corroborados por REBELO e col. (1999) que propõem que a redução da concentração de cálcio na hemolinfa ocorre para manutenção do pH do caranguejo Neohelice granulata, levando ao aumento do pH intracelular, evitando prejuízos decorrentes da acidificação do meio.

É possível sugerir também que como estratégia de sobrevivência os níveis de cálcio aumentaram em torno de três vezes para que o pH fisiológico desses animais fosse reestabelecido e, consequentemente, não fossem desencadeados novos processos de intoxicação que pudessem interferir na fisiologia e bioquímica desses caranguejos semiterrestres de mangue. 


\section{CONCLUSOES}

Elevadas concentrações de metais induzem efeitos osmorregulatórios e respiratórios em crustáceos. Distúrbios ionorregulatórios são efeitos comuns da exposição a metais, embora os mecanismos subjacentes possam ser diferentes, dependendo do metal considerado.

Com base nos resultados obtidos no presente trabalho e levando em consideração os dados existentes na literatura é possível concluir que:

- a osmolalidade tanto da hemolinfa quanto da urina sofreu alterações em decorrência do tempo de exposição e da concentração do metal utilizado, ocasionando possivelmente uma perda do controle osmótico e, consequentemente, uma alteração da homeotase dos caranguejos de mangue, a qual, por sua vez, pode afetar a sobrevivência destes animais;

- a alteração da concentração de sódio da hemolinfa e urina sugere a existência de competição do cobre com íons sódio, levando a uma perda da regulação do transporte de sódio e cobre. Porém, pode também acontecer um aumento da concentração de sódio resultante do aumento da osmolalidade plasmática e a perda de sódio pode ser devido a danos causados na estrutura branquial;

- como não houve alteração da concentração de potássio tanto na hemolinfa quanto na urina dos caranguejos de mangue, pode-se sugerir que a concentração de cobre utilizada e/ou o tempo de exposição não tenham sido suficientes para causar alguma alteração osmorregulatória dependente deste íon;

- o aumento gradativo da concentração de magnésio na hemolinfa de acordo com o tempo de exposição sugere que a presença de cobre pode causar diversos efeitos deletérios na osmorregulação. Porém, o grupo exposto ao cobre durante 15 dias apresentou concentração de cobre na urina menor que aquela dos demais grupos experimentais, sugerindo que talvez sejam acionadas estratégias para garantir o equilíbrio osmorregulatório do caranguejo;

- a alteração da concentração de cálcio na hemolinfa dos caranguejos expostos ao cobre durante 15 dias sugere ajuste para conter e regular a redução do pH da hemolinfa; 
Capítulo 2 - Transporte de cobre em celulas epiteliais de branquias e hepatopancreas do caranguejo de mangue Ucides cordatus 


\section{RESUMO}

As brânquias são expostas ao meio ambiente e é o primeiro órgão afetado pela poluição, enquanto que o hepatopâncreas é um órgão responsável por diversas funções como absorção, digestão, destoxificação e acúmulo de metais. O objetivo deste estudo foi o de caracterizar o transporte de cobre utilizando o marcador fluorescente Phen Green, em células epiteliais do caranguejo Ucides cordatus. Quando $\mathrm{CuCl}_{2}$ é adicionado em concentrações crescentes no meio, obtém-se uma curva da cinética de saturação tanto para as células das brânquias anteriores como para as das brânquias posteriores (Vmax para brânquias anteriores e posteriores: 0,2262 e $0,2683 \mu \mathrm{M} / 22.10^{4}$ células/30seg, e valores de $\mathrm{Km}: 0,7565 \mu \mathrm{M}$ e $0,8751 \mu \mathrm{M}$, respectivamente), enquanto que para as células de hepatopâncreas foi de: 3,1120 , $3,7160,3,9530,2,3400 \mu \mathrm{M} / 22.10^{4}$ células/30seg, respectivamente para as células $E, R / F(1)$, R/F(2) e B. Nifedipina, droga inibidora de canais de cálcio na membrana plasmática, reduziu o cobre intracelular tanto nas brânquias como no hepatopâncreas. O mesmo aconteceu com verapamil, que também é um inibidor de canais de cálcio. Neste caso, houve também um efeito sobre os valores de $\mathrm{Km}$ nas células de brânquias anteriores e posteriores, e nas células $R / F(1), R / F(2)$ e células $B$. Já as células $E$, apresentaram um aumento do influxo de cobre na presença de verapamil. Todavia, quando as células de brânquias e de hepatopâncreas foram incubadas em cálcio, os resultados obtidos foram contraditórios entre os tipos celulares. Isto é, os dois tipos de células das brânquias, as células $E$ e as populações de células R/F apresentaram redução da entrada de cobre, na presença de cálcio. Porém, as células B apresentaram aumento do influxo do metal, na presença de cálcio no meio externo. Amiloride, inibidor do trocador $\mathrm{Na} / \mathrm{Ca}$, assim como a bafilomicina (inibidor de ATPases dependentes de hidrogênio), causaram grande aumento do efluxo de cobre para o meio extracelular. Ouabaína e KB-R 7943, que atuam na homeostase do sódio, inibiram a tomada de cobre em todos os tipos celulares. Além disso, quando as brânquias foram expostas ao ATP, ocorreu aumento significativo da tomada de cobre que foi amplamente inibida pelo vanadato, inibidor de P-ATPases, indicando a presença de Cu-ATPase nas células, as quais são responsáveis pelo influxo de cobre. Já os experimentos com cafeína, por outro lado, mostraram um aumento do influxo de cobre para o meio intracelular, sugerem que a disponibilidade de cálcio intracelular afeta a tomada de cobre. Em geral, os resultados mostraram que a captação de cobre nas células de brânquias do caranguejo é regulada pela concentração intracelular de cálcio, por canais de cálcio e por trocadores dependentes de sódio.

Palavras-chave: brânquias, cálcio, Cu-ATPase, hepatopâncreas, Ucides cordatus. 


\section{ABSTRACT}

Gills are exposed to the environment as the primary organ affected by pollution, while the hepatopancreas is an organ responsible for different functions such as absorption, digestion, detoxification and accumulation of metals. The aim of this study was to characterize the transport of copper using Phen Green fluorescent dye in cells of gills and hepatopancreas of the mangrove crab Ucides cordatus. The addition of increasing concentrations of $\mathrm{CuCl}_{2}$ resulted in saturation kinetic curves for both anterior and posterior gill cells (Vmax for anterior and posterior gills: 0,2262 and $0,2683 \mu \mathrm{M} / 22.10^{4}$ cells/30sec, and values of $\mathrm{Km}: 0,7565 \mu \mathrm{M}$ e $0,8751 \mu \mathrm{M}$, respectively) while for cells of hepatopancreas, the values are $3,1120,3,7160$, $3,9530,2,3400$ for $E, R / F(1), R / F(2)$ and $B$ cells, respectively. Nifedipine, a drug known to inhibit calcium channels on the plasma membrane reduced the intracellular copper in gills and hepatopancreas. The same trend happened when verapamil, also a calcium channel inhibitor, was used. In this case, an effect on the $\mathrm{Km}$ values was also observed in the anterior and posterior gill cells, as well as in $R / F(1), R / F(2)$ and $B$ cells. However, E cells showed an increased influx of copper in the presence of verapamil. When gill cells and hepatopancreas were incubated in calcium, contradictory results were observed among cell types, i.e., both cell types in the gills, E cells and R/F cell populations showed reduced copper inflow in the presence of calcium. However, B cells showed increased influx of copper in the presence of calcium in the external medium. Amiloride, an inhibitor of the $\mathrm{Na} / \mathrm{Ca}$ exchanger, and bafilomicina (hydrogen dependent ATPase inhibitor) caused a significant increase in the efflux of copper into the extracellular medium. Ouabain and KB-R 7943 , known to play roles on sodium homeostasis, inhibited the outflow of copper in all cell types. Furthermore, when the gills were exposed to ATP, a significant increase in the copper influx occurred, which was largely inhibited by vanadate, an inhibitor of phosphorus dependent ATPases. This indicates the presence of CU-ATPase in the epithelial cells investigated, which are responsible for the influx of copper. Caffeine, on the other hand, increased the influx of copper to the intracellular environment, suggesting that the availability of intracellular calcium affects the uptake of copper. In general, the results showed that the uptake of copper into the gill cells of the mangrove crab is regulated by intracellular calcium concentration, calcium channels and sodium dependent exchangers. In this study

Keywords: gills, calcium, Cu-ATPase, hepatopancreas, Ucides cordatus. 


\section{INTRODUÇAO}

Os metais são os poluentes mais comuns e estão presentes nas mais diversas áreas de costa ao em todo o mundo. Metais de transição, como por exemplo, cobre, zinco, ferro, cobalto ou manganês, são essenciais para a manutenção da saúde da maioria dos organismos, estando presente na composição de diversas proteínas envolvidas nas mais diversas funções biológicas (GROSELL e col., 2004). No entanto, em excesso, esses metais se tornam tóxicos, ligando-se inapropriadamente a moléculas biológicas ou formando perigosos radicais livres. Portanto, para manter a homeostase desses metais, através do balanço entre absorção e excreção, é necessário haver um fino balanço de suas concentrações já que eles são vitais para os organismos na sua maioria (GROSELL e col., 2004).

\section{Cobre}

O cobre $(\mathrm{Cu})$ é um íon essencial que atua nas mais diversas reações enzimáticas, na síntese de hemoglobina, elastina e colágeno, eliminação de radicais livres e também está presente no metabolismo do ferro (UAUY e col., 1998). Além disso, o cobre também é utilizado para o transporte de elétrons na mitocôndria, defesa de patógenos, metabolismo de carboidratos, além de atuar diretamente na proteção contra o estresse oxidativo $(\mathrm{Cu} / \mathrm{Zn}$ superóxido dismutase) (CHAVEZ-CROOKER e col., 2001). Porém, torna-se tóxico em altas concentrações, modificando a composição lipídica e proteica da membrana plasmática gerando altos níveis de radicais livres no interior das células, atuando, assim, como agente próoxidante (CHAVEZ-CROOKER e col., 2003a;b). A essencialidade e toxicidade do cobre requerem a presença de um mecanismo preciso para sua aquisição, o qual está intimamente relacionado à sua distribuição controlada (PUIG \& THIELE, 2002).

\section{Transporte de Cobre}

Para manter a concentração de metais essenciais dentro do padrão fisiológico (que é variável entre os diversos grupos taxonômicos) são necessários diversos mecanismos que controlam a sua ingestão, acúmulo, distribuição e destoxificação (SHINGLES e col., 2004). As principais rotas para a homeostase do metal são: regulação de transporte na membrana 
plasmática, ligação intracelular a proteínas, como metalotioneínas, e compartimentalização em lisossomos, mitocôndrias e retículo endoplasmático, por exemplo (CHAVEZ-CROOKER e col., 2001; 2003a;b; AHEARN e col., 2004).

O transporte de cobre em membrana plasmática de animais e plantas envolve membros de P-ATPases, dependentes de fósforo (HARRIS \& SANTOS, 2000). Estas ATPases foram sequenciadas para o entendimento das doenças de Wilson e de Menke, conhecidas por causar metabolismo anormal de cobre em seres humanos como citado anteriormente na introdução geral (HARRIS \& SANTOS, 2000). Em peixes, o transporte de cobre tem sido estudado, utilizando-se o radioisótopo de cobre $\left({ }^{64} \mathrm{Cu}^{2+}\right.$ ) (WHEATLY e col., 1999; GROSELL \& WOOD, 2002), e em lisossomos e mitocôndrias de hepatopâncreas de lagostas (CHAVEZCROOKER e col., 2001; 2003a;b; AHEARN e col., 2004) e em células de brânquias e hepatopâncreas de siris (PAGANINI \& BIANCHINI, 2009), utilizando-se marcadores fluorescentes, como o Phen Green.

Fora da membrana apical, o íon precisa estar biológica e quimicamente disponível para entrar pelo canal da membrana ou, então, estar ligado a proteínas de membrana. O íon é considerado biodisponível quando se encontra sob a forma livre e hidratada (RAINBOW, 2000). É dessa maneira que muitos íons de metais entram passivamente nas células, os quais, por sua vez, são transportados através da membrana apical por canais de membrana de grande afinidade (RAINBOW, 2000).

Existem três mecanismos homeostáticos para entrada de metais nas células: (i) ligação em sítios específicos como em moléculas ligantes (sendo a metalotioneína a mais importante); (ii) compartimentalização em vesículas de membranas, mais frequentemente presentes em lisossomos; (iii) formação de precipitados insolúveis como concreções $\mathrm{Ca} / \mathrm{Mg}$ ou grânulos $\mathrm{Ca} / \mathrm{S}$. Estes mecanismos apresentam diversos graus de eficácia em diferentes organismos e em diferentes tipos de células no mesmo organismo (VIARENGO \& NOTT, 1993).

Várias rotas têm sido propostas para o transporte de metais através da membrana citoplasmática, sendo elas: (i) transporte iônico mediado por ligação do metal à membrana; uma vez no citosol, o metal se liga a proteínas e então é continuadamente transportado de forma passiva na célula, fazendo com que o metal se torne, consequentemente, indisponível para retornar ao meio externo (RAINBOW \& DALLINGER, 1993); (ii) transporte através de canais de proteínas onde os íons de metal são transportados por gradiente hidrofílico; (iii) difusão passiva do metal na bicamada lipídica dissolvida; e, (iv) endocitose - englobamento de partículas ferro-metálicas as quais são transferidas para vesículas intracelulares. Essas duas 
últimas rotas são, provavelmente, as de menor importância para a tomada típica de metais da solução pelos crustáceos aquáticos (RAINBOW, 2000; BROUWER e col., 2002; RAINBOW \& BLACK, 2005). Além disso, a tomada junto à membrana celular é governada por transportadores específicos, transporte por canais de proteínas, difusão passiva de metais lipossolúveis e, também, por endocitose (ALCORLO e col., 2006).

Diversas proteínas de transporte envolvidas na tomada de cobre, transporte intracelular, sequestro e efluxo do metal têm sido identificadas em mamíferos (GROSELL \& WOOD, 2002). Nos mamíferos, o cobre é transportado por uma ATPase de cobre (Cu-ATPase), a qual apresenta sequência de ligantes de metal análoga desde bactérias até seres humanos, implicando, desse modo, que a mesma sequência ocorra também em peixes e outros organismos como os crustáceos (CAMPBELL e col., 1999).

Além disso, tais proteínas carreadoras podem ser específicas a determinados íons metálicos ou possuir afinidade catiônica por uma diversidade ampla de metais (SIMKISS \& TAYLOR, 1989; DEPLEDGE \& RAINBOW, 1990; RAINBOW, 1995). Após a tomada, tanto através da superfície ectodérmica permeável como através da endoderme da glândula digestiva, o cobre se tornará disponível para ser metabolizado, apresentando, assim, potencial de ligação às moléculas receptoras nas células, após ser transportado pela hemolinfa (RAINBOW, 2007).

Estudos fisiológicos e bioquímicos sugerem a presença de pelo menos dois processos responsáveis pela tomada de cobre em células eucarióticas, as quais apresentam afinidades e capacidades distintas (PUIG \& THIELE, 2002). GROSELL \& WOOD (2002) identificaram dois processos apicais de tomada de cobre, isto é, uma rota sensível e outra insensível ao sódio.

O estudo de GROSELL \& WOOD (2002) revelou duas rotas diferentes para a tomada de cobre pelas brânquias: (i) baseada na competição da tomada de cobre pela redução da concentração de sódio no ambiente e na sensibilidade da proporção da tomada de cobre por fenamil e bafilomicina A1 (BURY, 2003), onde um dos caminhos de tomada aparenta ser através de canal apical de sódio (canal presente nas brânquias de trutas); ou (ii) a tomada de cobre é sugerida como sendo contínua, uma vez na presença de altas concentrações de sódio no ambiente (1-20 mmol/L). Dependendo da concentração de cobre no ambiente externo, a tomada deste metal por meio do mecanismo sensível ao sódio é de duas a cinco vezes maior do que aquela que ocorre pela via insensível ao sódio, sugerindo que a rota sensível ao sódio possa ser modulada pelo status interno deste cátion, além dos níveis de sódio presentes na água (GROSELL \& WOOD, 2002; MATSUO e col., 2005). 


\section{Transporte em Brânquias}

As brânquias de crustáceos são órgãos multifuncionais, os quais, além de participar das trocas gasosas, são essenciais para a homeostase osmótica e iônica (FREIRE e col., 2008), permitindo o transporte seletivo de osmólitos e a excreção de nitrogênio, além de participar dos processos de equilíbrio ácido-base e da regulação do volume celular (COPELAND \& FITZJARREL, 1968; LUCU \& TOWLE, 2003).

Comparadas com outras partes do corpo, as brânquias se encontram em contato direto com o meio externo, sendo, portanto, os primeiros órgãos a serem afetados por poluentes provenientes de águas contaminadas às quais muitos animais estão expostos (SOEGIANTO e col., 1999). Muitos estudos têm abordado a tomada de metais pesados pelas brânquias de peixes e os mecanismos fisiológicos subjacentes a esse processo (ZHANG \& WANG, 2007). Estudos toxicológicos demonstraram que elevadas concentrações de cobre na água podem levar a um aumento de cobre, particularmente nas brânquias e fígado, sugerindo que as brânquias possam servir como rota de tomada de cobre (GROSELL \& WOOD, 2002).

GROSELL \& WOOD (2002) sugerem o envolvimento de proteínas transportadoras de cobre mais específicas. A membrana apical do epitélio branquial tem dois sítios de ligação ao cobre (i) sítios de ligação de baixa capacidade e alta afinidade, quando as concentrações de cobre são baixas e (ii) sítios de alta capacidade e baixa afinidade de ligação, quando o cobre estiver presente em altas concentrações. No entanto, quando ocorre saturação da superfície branquial, o cobre passa para compartimentos intracelulares, como mitocôndrias, lisossomos e retículo endoplasmático, favorecendo o acúmulo do metal dentro da célula (MONTEIRO e col., 2005).

\section{Transporte em Hepatopâncreas}

O hepatopâncreas dos crustáceos é análogo ao fígado dos vertebrados sendo essencialmente composto por microtúbulos que são compostos por quatro tipos de células diferentes $(E, R, F, B)$, as quais já foram descritas na introdução geral deste manuscrito. Como no caso do fígado dos vertebrados, o hepatopâncreas dos invertebrados é um órgão sensível aos danos causados por poluentes existentes no meio externo (LI e col., 2007).

A existência de processos apicais nas células de hepatopâncreas, cujas membranas apresentam borda em escova (BBM) (ZANOTTO \& WHEATLY, 2002), tem sido documentada 
apenas na lagosta Homarus americanus. Ainda que se saiba que o cobre seja essencial como elemento traço, participando como co-fator em uma série de reações bioquímicas, o conhecimento de sua homeostase pelas células eucarióticas é ainda muito fragmentado (KNOPFEL e col., 2005).

\section{Cálcio}

A tomada de cálcio pela memebrana apical é amplamente passiva, envolvendo canais e trocadores eletroneutros e eletrogênicos de $\mathrm{Ca}^{2+} / \mathrm{Na}^{+}$(WHEATLY e col., 1999). A homeostase de cálcio é outra função importante das brânquias e de suma importância para organismos que estão no processo de ecdise, além de os transportadores de cálcio e $\mathrm{NH}_{4}^{+}$também contribuírem para o equilíbrio do pH do meio interno (FREIRE e col., 2008).

A tomada de cálcio, via canal na membrana apical, ocorre de modo passivo e por meio de gradiente eletroquímico. A baixa concentração de cálcio intracelular (da ordem de micromoles) é mantida por uma bomba enzimática, a qual libera cálcio para o sangue, através da membrana basal dos ionócitos branquiais, talvez envolvendo uma Ca-ATPase basal, e/ou interação entre uma $\mathrm{Na}^{+} / \mathrm{K}^{+}$-ATPase e uma anidrase carbônica (RAINBOW, 2000). Porém, elevações do nível de cálcio na água (geralmente em torno de $10 \mathrm{mM}$ ) inibem ou reduzem a entrada de metais como cádmio e zinco, nos peixes (WOOD, 1992).

O presente modelo de tomada de cálcio corrobora a ideia de que este transita nas células por meio de difusão passiva, ao longo do gradiente eletroquímico e através de um canal seletivo ao cálcio dependente de voltagem (WOOD, 1992). A tomada de cálcio do lúmen, através da membrana apical, ocorre pela combinação de três processos: dois tipos diferentes de antiporters que são capazes de trocar cálcio externo por sódio ou hidrogênio intracelulares e um terceiro que se dá por um canal de cálcio presente na membrana (ZANOTTO \& WHEATLY, 2002).

\section{Cálcio versus Cobre}

Existem diversos exemplos de interações entre metais e vários aspectos do metabolismo de cálcio, evidenciando o compartilhamento de um mecanismo regulatório epitelial entre cálcio e metais (WRIGHT, 1995). Alguns autores sugerem que zinco e cálcio compartilham, em certa medida, de uma tomada comum, através de rotas do epitélio 
branquial de trutas aclimatadas em água doce. Os estudos realizados por esses autores demonstraram que o cálcio é um inibidor competitivo de influxo de zinco e vice-versa, assim como com o cobre (GALVEZ e col., 1998; HOGSTRAND e col., 1998).

Com base nas evidências supracitadas, foram investigadas quais são as rotas utilizadas para o transporte de cobre através das brânquias anteriores e posteriores assim como através dos quatro tipos celulares do hepatopâncreas de células isoladas do caranguejo de mangue Ucides cordatus. A hipótese sobre a qual o presente trabalho se apoia é a de que o íon cobre interaja com transportadores de cálcio, já que ambos são cátions divalentes e dados da literatura apresentam estes dois elementos como competidores entre si em outros grupos de organismos. 
OBJETIVOS

\section{Geral}

O objetivo geral deste estudo foi caracterizar a entrada de cobre nas células epiteliais de brânquias e de hepatopâncreas do caranguejo de mangue Ucides cordatus, uma vez que alterações osmorregulatórias podem afetar a composição de membrana que possui função crucial na tomada de íons em geral do meio externo para o meio interno.

\section{Específicos}

- Para tal caracterização, as brânquias foram divididas em anteriores (predominantemente respiratórias) e posteriores (predominantemente osmorregulatórias);

- Separação dos quatro tipos celulares do hepatopâncreas em gradiente descontínuo de sacarose;

- Para determinação das rotas de entrada de cobre nas células epiteliais das brânquias e de hepatopâncreas foram utilizados:

- Inibidores de canais, trocadores e bombas de membrana plasmática, tanto apical quanto basolateral;

- Inibidores de canais e trocadores de $\mathrm{Ca}^{2+}$, como verapamil, nifedipina, além do uso de cafeína e do próprio cálcio;

- Inibidores de trocadores de $\mathrm{Na}^{+}$, como ouabaína, amiloride e K-BR 7943;

- Inibidores de ATPases, como vanadato (Ca-ATPase) e bafilomicina (H-ATPase), assim como o uso de ATP como fonte estimulatória destas ATPases. 


\section{PARTE EXPERIMENTAL}


MATERIAL E MÉTODOS 


\section{MATERIAL E METODOS}

\section{Animais}

Neste estudo, utilizou-se 40 machos de Ucides cordatus, com massa corpórea média de ordem de 156,00 \pm 4,61 g, coletados no estuário próximo à Praia dos Pescadores, Itanhaém, Sul do Estado de São Paulo, Brasil. A Estância Balneária de Itanhaém compreende uma área de $597,4 \mathrm{~km}^{2}, 46047^{\prime} 15^{\prime \prime}$ Oeste e 24 11' 08' Sul, e está situada num ecossistema, o mangue, que consiste na transição entre terra e mar, tipicamente encontrado em regiões tropicais e subtropicais (IGARASHI,2008).

Após a coleta, os caranguejos foram aclimatados no Biotério da Universidade Presbiteriana Mackenzie durante sete dias em água do mar em salinidade 20\%, 12C:12E, $25 \pm$ $1^{\circ} \mathrm{C}$, e alimentados com alface e carne moída em dias alternados. Somente após o período de aclimatação, os experimentos com a presença de cobre na água foram realizados.

\section{Experimentos}

Os 40 caranguejos machos foram aleatoriamente divididos em quatro grupos (Controle, 24h, 96h e 15 dias de exposição ao cobre na água) e, antes de serem colocados em aquários de $15 \mathrm{~L}$ com paredes encapadas de preto, os animais foram pesados em balança Denver Instrument Company TR-402, bem como logo após o término de cada experimento, para haver controle da massa dos indivíduos ao término dos experimentos realizados com cada grupo experimental, a qual não sofreu variação significativa ao longo dos dias de experimento.

Em cada aquário de $15 \mathrm{~L}$ foram colocados $5 \mathrm{~L}$ de água do mar $20 \%$ o para que os animais não ficassem cobertos de água (sendo este mais um fator de estresse evitado) e para não impedir a sua rotina diária de imersão e emersão. A troca de água foi feita diariamente, com a adição de $5 \mathrm{mg} / \mathrm{L} \mathrm{CuSO}_{4}$ para obter $2 \mathrm{mg} / \mathrm{L}$ cobre, a fim de garantir a mesma exposição de cobre à todos os animais com aeração constante para todos os aquários. 
Ao final dos experimentos e de acordo com seus respectivos intervalos de tempo (24h, $96 \mathrm{~h}$ e 15 dias), os animais foram crio-anestesiados para dessensibilização durante 15 a 20 minutos em freezer comum.

As partes dorsal e ventral foram separadas manualmente para que então, com o auxílio de pinças e tesouras, fossem retiradas as brânquias anteriores ( 3 primeiras) e posteriores (2 últimas), e o hepatopâncreas. Logo em seguida, os órgãos foram colocados em solução salina de composição similar à hemolinfa dos animais, com a seguinte composição: $395 \mathrm{mM} \mathrm{NaCl}, 10 \mathrm{mM} \mathrm{KCl}, 2,5 \mathrm{mM} \mathrm{NaHCO}{ }_{3}, 2,5 \mathrm{mM} \mathrm{NaH}_{2} \mathrm{PO}_{4}, 3,75 \mathrm{mM}$ Hepes, 1 mM glicose, pH 7.8, $730 \mathrm{mOSm} \mathrm{Kg}^{-1} \mathrm{H}_{2} \mathrm{O}$.

\section{Dissociação Celular das Brânquias}

Quando retiradas dos animais, as brânquias foram colocadas em solução salina isosmótica à hemolinfa dos caranguejos com tripsina 0,05\% e foram mantidas nesta solução, durante 15 minutos, para digestão da camada de quitina que as recobre. A dissociação das células branquiais foi realizada com tesouras. As células foram agitadas em 10x g, durante 15 minutos, para completa dissociação celular. Este procedimento foi repetido por duas vezes para se obter a maior quantidade de células possível (SÁ e col., 2010).

\section{Dissociação Celular do Hepatopâncreas}

Para a dissociação das células do hepatopâncreas, este, após a sua completa remoção do caranguejo, foi colocado diretamente em béquer contendo a mesma solução salina isosmótica utilizada para a dissociação das brânquias. A dissociação celular foi feita com o uso de um agitador magnético a 10x g e, após esta etapa, as células foram filtradas em malha de $200 \mu \mathrm{m}$ para em seguida serem acondicionadas em tubos de ensaio.

Vale ressaltar que, tanto para as brânquias quanto para o hepatopâncreas, toda a etapa de dissociação celular e a separação por gradiente descontínuo de sacarose ocorreram com a utilização de gelo. 


\section{Separação em Gradiente Descontínuo de Sacarose}

Como citado na Introdução, o hepatopâncreas é um órgão multifuncional composto por 4 tipos de células, E, R, F e B. Para a separação dos tipos celulares por meio da diferença de densidade, foi utilizado um gradiente descontínuo de sacarose $(10,20,30$ e 40\%). Tal separação foi obtida após 30 minutos de centrifugação a $5000 x \mathrm{~g}$ e à $4^{\circ} \mathrm{C}$. As células $\mathrm{E}$ foram obtidas do gradiente $10 \%$ e as células B do gradiente $40 \%$. Estas células são aquelas de menor e maior densidade, respectivamente. Já as células $\mathrm{R}$ e $\mathrm{F}$ que possuem densidade muito similar e foram obtidas nos gradientes 20 e $30 \%$, onde houve mistura de ambas as células. As células obtidas no gradiente $20 \%$ foram denominadas células $R / F(1)$ e no gradiente $30 \%, R / F(2)$, já que para que houvesse a separação destas células seria necessário outros tipos de centrifugação, como elutriation centrifugation, inacessíveis durante a realização dos experimentos. Após a centrifugação em sacarose, as células foram re-suspensas em solução salina e mantidas em gelo por todo o período de preparo das células de brânquias e hepatopâncreas.

\section{Marcador Fluorescente}

Ao término da etapa de dissociação, tanto para as brânquias quanto para o hepatopâncreas, as células foram centrifugadas a $50 \mathrm{x}$ g durante 5 minutos, à $4^{\circ} \mathrm{C}$. O pellet de células foi retirado e re-suspenso em $1 \mathrm{~mL}$ de solução salina para a adição de 1,5 $\mu \mathrm{M}$ de Phen Green, FL (Molecular Probes, Inc.), ligante de metal fenantrolina covalentemente ligado à fluorescina (SHINGLES e col., 2004), com ondas de emissão 520 nm e excitação 490 nm. Para que o marcador fluorescente penetrasse as células, foi necessária uma hora de agitação permanente a 10x g. Após esta etapa, as células foram centrifugadas novamente a 150x g para remoção do marcador que não permeou as células através do descarte da solução sobrenadante e novamente ressuspendendo o pellet de células em solução salina isosmótica.

\section{Contagem das Células}

Para estimar a viabilidade celular (que foi aproximadamente de $85 \%$ ) em Câmara de Neubauer, utilizou-se $20 \mu \mathrm{L}$ de Azul Tripan adicionado a $180 \mu \mathrm{L}$ de células (brânquias e hepatopâncreas). Uma vez determinado o número de células presente em cada cultura primária obtida da dissociação dos tecidos, estas culturas primárias foram ajustadas com 
diluição para $22.10^{4} \pm 5$ células $/ \mathrm{mL}$, com o intuito de padronização dos experimentos, evitando-se, assim, grande variabilidade para a análise dos resultados.

\section{Desenho Experimental}

Para caracterizar o transporte de cobre nas células de brânquias e hepatopâncreas do caranguejo de mangue Ucides cordatus foram utilizados inibidores que atuam em canais e trocadores de cálcio, assim como os dependentes de sódio e ATP. Para se investigar o efeito dessas substâncias, as células dissociadas foram monitoradas durante 300 segundos para cada concentração externa de $\mathrm{CuCl}_{2}\left(0 ; 0,025 ; 0,150 ; 0,275 ; 0,550 ; 1,110 \mu \mathrm{M} \mathrm{CuCl}_{2}\right)$ adicionada após 30 segundos de monitoramento das células a fim de se detectar a presença do cobre intracelular livre. Para tal, contou-se com o auxílio do software $K C$ Junior do espectrofluorímetro Bio Tek FLX 800 a $25 \circ \mathrm{C}$. Para investigar o transporte de cobre foram utilizados os inibidores apresentados na Tabela 1.

Tabela 1. Valores de concentrações finais de cada inibidor utilizado para determinação da concentração intracelular de $\mathrm{Cu}^{+}$livre para as células de brânquias e hepatopâncreas.

\begin{tabular}{cc}
\hline Inibidores & Concentração Final \\
\hline Amiloride & $200 \mu \mathrm{M}$ \\
\hline Verapamil & $50 \mu \mathrm{M}$ \\
Nifedipina & $100 \mu \mathrm{M}$ \\
ATP & $1.5 \mathrm{mM}$ \\
Ouabaína & $2 \mathrm{mM}$ \\
\hline Ortovanadato de Sódio & $20 \mathrm{mM}$ \\
KB-R 7943 & $20 \mu \mathrm{M}$ \\
Cafeína & $20 \mu \mathrm{M}$ \\
Bafilomicina & $2 \mu \mathrm{M}$ \\
Cálcio & $20 \mathrm{mM}$ \\
\hline
\end{tabular}

Tanto para amiloride como para bafilomicina, os resultados foram apresentados em RFU (unidade arbitrária de fluorescência). Em razão das particularidades que tal marcador fluorescente apresenta, isto é, quanto maior o nível de $\mathrm{Cu}^{+}$intracelular livre, menores os valores apresentados, a detecção de valores muito elevados indica níveis de $\mathrm{Cu}^{+}$livre não detectáveis no citoplasma celular. 


\section{Calibração de Cobre Intracelular}

Após cada experimento, o procedimento de calibração, adaptado do método de MERRIT e col. (1990), foi utilizado para calcular os níveis de $\mathrm{Cu}^{+}$intracelular livre. Ao final dos experimentos, as células não expostas ao cobre extracelular sofreram lise, através da adição de $10 \mu \mathrm{L}$ de Triton X-100 20\%, aguardando-se em torno de 15 minutos. Para obter a fluorescência máxima (Fmax), adicionu-se $5 \mu \mathrm{L}$ de EDTA 200 mM (Sigma-Aldrich) duas vezes, para assegurar total quelação do cobre. Já para obter a fluorescência mínima (Fmin), foram adicionados $25 \mathrm{mM}$ de $\mathrm{CuCl}_{2}$ às células que sofreram lise previamente.

Para calcular a concentração de $\mathrm{Cu}^{+}$intracelular para cada experimento, foi utilizada a equação descrita no trabalho de CHAVEZ-CROOKER e col., (2002):

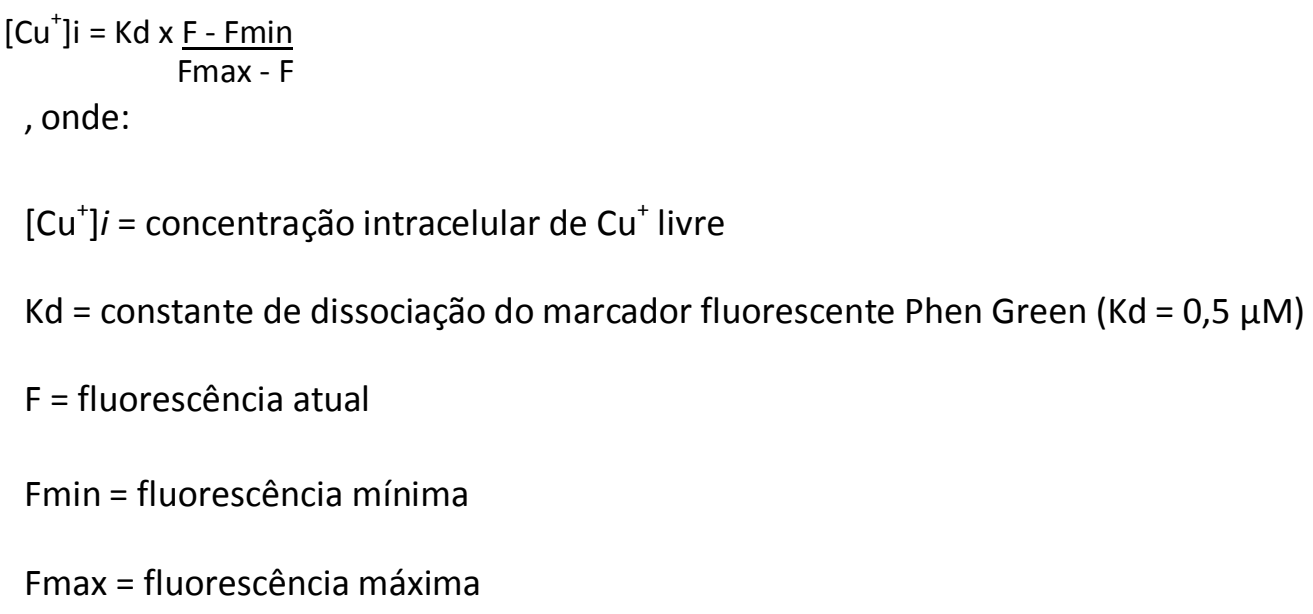

\section{Análise dos Dados}

Todos os resultados foram plotados, utilizando-se o programa Prism Graph Pad 5 (Graph Pad Software Inc., La Jolla, CA, EUA), e analisados com auxílio do programa Sigma Stat 3.1. Aplicou-se o teste de análise de variância (ANOVA), através do teste $T$, comparando-se valores de $\mathrm{Km}$ e Vmax, tanto para os grupos controle quanto para os experimentais. 
RESULTADOS

\section{Brânquias}

A figura 1 apresenta as cinéticas de entrada de cobre tanto nas células anteriores quanto nas posteriores do caranguejo de mangue Ucides cordatus, onde é possível observar que as brânquias posteriores apresentaram maior velocidade de transporte do que as brânquias anteriores, com diferença estatística significativa $(p<0,001)$ quando comparados os valores da velocidade de entrada do íon do metal, porém quando analisados os valores de $\mathrm{Km}$, que corresponde à afinidade do metal por canais, transportadores, dentre outras proteínas, não houve diferença estatisticamente significativa.

Tabela 2. Valores de Vmax $(\mu \mathrm{M})$ e $\mathrm{Km}(\mu \mathrm{M})$ para células de brânquias anteriores e posteriores de Ucides cordatus (média $\pm \mathrm{EP} ; \mathrm{N}=4$ ), onde asteriscos indicam diferença estatística significativa entre os parâmetros cinéticos apresentados para as células de brânquias(ANOVA, teste T).

\begin{tabular}{ccc}
\hline Células & \multicolumn{1}{c}{$\operatorname{Vmax}(\mu \mathrm{M})$} & $\mathrm{Km}(\boldsymbol{\mu M})$ \\
\hline Anterior & $0,4045 \pm 0,0596$ & $0,4416 \pm 0,0392$ \\
Posterior & $1,7550 \pm 0,2711^{* * *}$ & $0,3152 \pm 0,0267$ \\
\hline
\end{tabular}

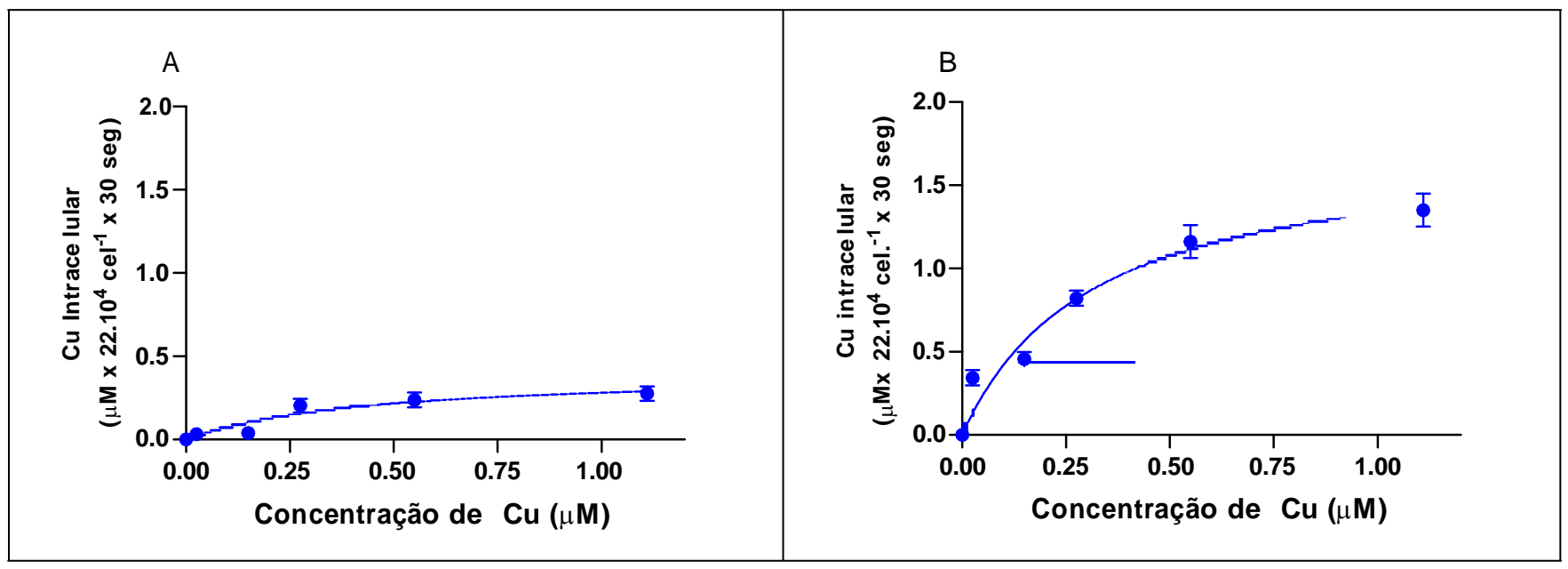

Figura 1. Transporte de cobre nas células epiteliais de brânquias de Ucides cordatus representando a concentração intracelular de $\mathrm{Cu}^{+}$em relação ao aumento crescente de cobre externo na forma de $\mathrm{CuCl}_{2}$ $(0,025 ; 0,150 ; 0,275 ; 0,55 ; 1.110 \mu \mathrm{M})$, onde $(A)$ representa a concentração intracelular de cobre $(\mu \mathrm{M} x$ $22.10^{4} \mathrm{cel}^{-1}$ x $30 \mathrm{seg}$ ) nas brânquias anteriores ao longo dos 300 segundos de leitura datomada de cobre; e (B) representa a concentração intracelular de cobre $\left(\mu \mathrm{M} \times 22.10^{4} \mathrm{cel}^{-1} \times 30 \mathrm{seg}\right)$ nas brânquias posteriores ao longo dos 300 segundos de leitura da tomada de cobre $(n=4)$. 
A figura 2 apresenta os resultados da entrada e disponibilidade do íon cobre livre no citoplasma em tempo real, durante 300 segundos de leitura e monitoramento das células. É possível observar que a figura $2 \mathrm{~A}$ apresenta níveis de cobre intracelular livre relativamente superiores aos resultados obtidos na figura 2B, que representa o obtido com as células epiteliais de brânquias posteriores. Em ambos os casos, nota-se que a maior concentração de cobre disponível no citoplasma celular é representada pela adição da maior concentração utilizada $(1,110 \mu \mathrm{M})$, ao passo que a menor concentração utilizada $(0,025 \mu \mathrm{M})$ é representada com os menores valores de cobre intracelular, indicando que as células, assim como nas demais concentrações utilizadas, responderam ao estímulo de concentrações crescentes de cobre no meio externo. É ainda possível observar que as duas menores concentrações utilizadas $(0,025$ e $0,150 \mu \mathrm{M})$ foram apresentadas como relativamente constantes, enquanto que as três demais concentrações de cobre utilizadas apresentaram níveis de cobre livre no meio intracelular continuadamente crescentes.

A análise estatística aplicada para comparação da concentração de cobre livre no meio intracelular no momento da injeção (30 segundos no gráfico) de $\mathrm{CuCl}_{2}$ ao meio de cultura juntamente com o último registro da concentração de cobre que ocorreu aos 300 segundos de monitoramento, apresentou diferença estatisticamente significativa para as concentrações $1,110 \mu \mathrm{M}$ em ambos os tipos celulares com $p<0,001$ e $p<0,01$ (respectivamente para brânquias anteriores e posteriores), assim como obteve-se diferença estatística na concentração de $0,275 \mu \mathrm{M}$, com $\mathrm{p}<0,01$ para brânquias posteriores. 


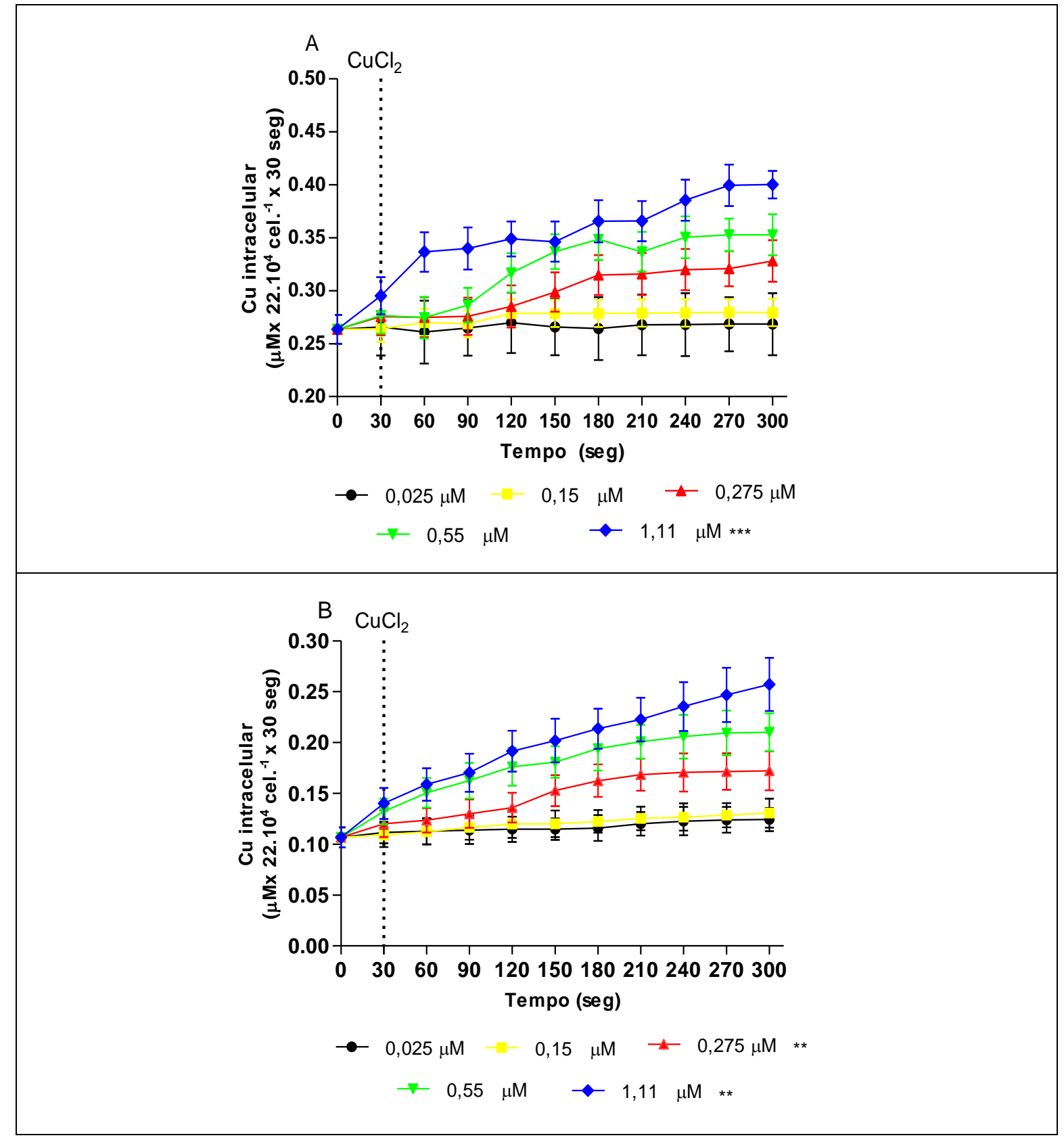

Figura 2. Transporte de cobre nas células epiteliais de brânquias de Ucides cordatus representando a concentração intracelular de $\mathrm{Cu}^{+}$em relação ao aumento crescente de cobre externo na forma de $\mathrm{CuCl}_{2}(0,025 ; 0,150 ; 0,275 ; 0,55 ; 1.110 \mu \mathrm{M})$ onde (A) apresenta a entrada de cobre em tempo real nas células das brânquias anteriores através da média de cada 30 segundos durante 300 segundos de leitura do espectrofotômetro; e (B) apresenta a entrada de cobre em tempo real nas células posteriores, onde tal entrada foi obtida através da média de cada 30 segundos de leitura noespectrofluorímetro durante 300 segundos $(n=4)$. 
$\mathrm{Na}$ figura 3, para ambos os grupos o íon cálcio se mostrou inibidor competitivo da tomada de cobre, reduzindo drasticamente sua entrada nas brânquias posteriores, com rápida redução da velocidade máxima de entrada do íon cobre, ao passo que nas brânquias anteriores, houve também redução, porém em 50\%, ao contrário das brânquias posteriores, que apresentaram redução de mais de 90\% da velocidade máxima de entrada nas brânquias do grupo controle, e dessa maneira houve diferença estatística significativa de $p<0,01$ e $p<0,001$, respectivamente para brânquias anteriores e posteriores, enquanto que os valores de $\mathrm{Km}$ foram somente significativamente diferentes quando comparados para as brânquias posteriores, com $p<0,05$, incubadas ou não em cálcio.

Tabela 3. Valores de Vmax ( $\mu \mathrm{M})$ e $\mathrm{Km}(\mu \mathrm{M})$ para células de brânquias anteriores e posteriores de Ucides cordatus (média $\pm \mathrm{EP} ; \mathrm{N}=4$ ), onde os asteriscos indicam diferença estatística significativa entre os parâmetros cinéticos apresentados para as células de brânquias (ANOVA, teste T).

\begin{tabular}{clc}
\hline Células & \multicolumn{1}{c}{ Vmax (uM) } & Km (uM) \\
\hline Anterior & $0,4045 \pm 0,1196$ & $0,4416 \pm 0,0299$ \\
\hline Anterior + cálcio & $0,1985 \pm 0,0323 * *$ & $0,2690 \pm 0,0212$ \\
Posterior & $1,7550 \pm 0,2711$ & $0,3152 \pm 0,0267$ \\
Posterior + cálcio & $0,1008 \pm 0,0089 * * *$ & $0,1652 \pm 0,0493 *$ \\
\hline
\end{tabular}

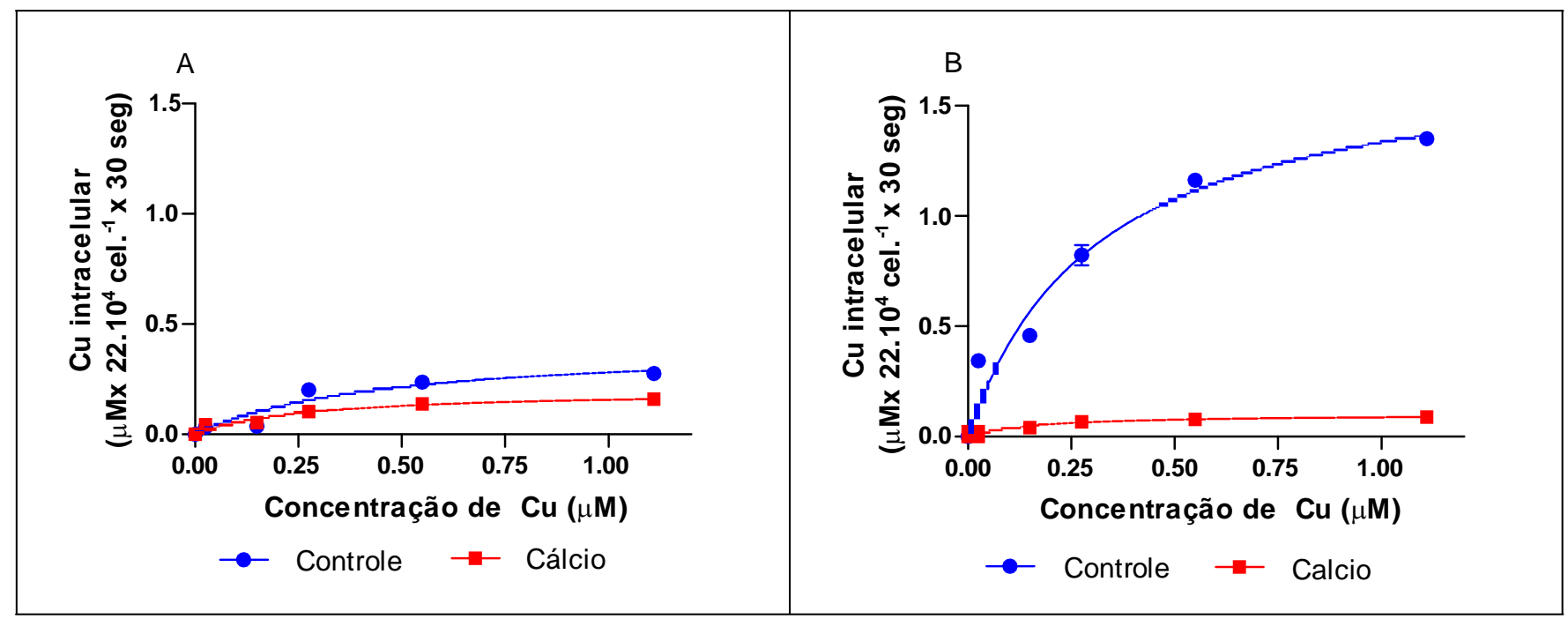

Figura 3. Transporte de cobre nas células epiteliais de brânquias de Ucides cordatus representando a concentração intracelular de $\mathrm{Cu}^{+}$em relação ao aumento crescente de cobre externo na forma de $\mathrm{CuCl}_{2}$ $(0,025 ; 0,150 ; 0,275 ; 0,55 ; 1.110 \mu \mathrm{M})$, onde $(A)$ representa a comparação da concentração intracelular de cobre ( $\mu \mathrm{M} \times 22.10^{4} \mathrm{cel}^{-1} \times 30 \mathrm{seg}$ ) nas brânquias anteriores controle e incubadas em $20 \mathrm{mM}$ de cálcio ao longo dos 300 segundos de leitura da tomada de cobre; e (B) representa a comparação da concentração intracelular de cobre $\left(\mu \mathrm{M} \times 22.10^{4} \mathrm{cel}^{-1} \times 30 \mathrm{seg}\right)$ nas brânquias posteriores controle e incubadas em 20 mM de cálcio ao longo dos 300 segundos de leitura da tomada de cobre $(n=4)$. 
Na figura 4 foi observado que para os dois tipos celulares houve redução da entrada de cobre, ambas apresentando diferença estatística significativa de $p<0,001$ para os valores de Vmax tanto das brânquias anteriores quanto das posteriores, comparando-se com as brânquias controle (tanto anterior quanto posterior). É possível notar que mesmo exercendo a mesma dinâmica em ambos os tipos celulares, o uso da nifedipina nas brânquias posteriores causou redução de aproximadamente 138x quando comparado com o grupo controle, enquanto que a redução nas brânquias anteriores foi de $45 x$. O mesmo foi observado para os valores de Km, que para os dois tipos de brânquias apresentaram redução dos valores de Km com valor de $p<0,001$ para ambas.

Tabela 4. Valores de Vmax $(\mu \mathrm{M})$ e $\mathrm{Km}(\mu \mathrm{M})$ para células de brânquias anteriores e posteriores de Ucides cordatus (média $\pm E P ; N=4$ ), onde os asteriscos indicam diferença estatística significativa entre os parâmetros cinéticos apresentados para as células de brânquias (ANOVA, teste T).

\begin{tabular}{clc}
\hline Células & \multicolumn{1}{c}{ Vmax (uM) } & Km (uM) \\
\hline Anterior & $0,4045 \pm 0,1196$ & $0,4416 \pm 0,1992$ \\
Anterior + Nifedipina & $0,0088 \pm 0,0016 * * *$ & $0,0894 \pm 0,0734 * *$ \\
Posterior & $1,7550 \pm 0,2711$ & $0,3152 \pm 0,0267$ \\
Posterior + Nifedipina & $0,0127 \pm 0,0015 * * *$ & $0,0185 \pm 0,0160 * * *$ \\
\hline
\end{tabular}

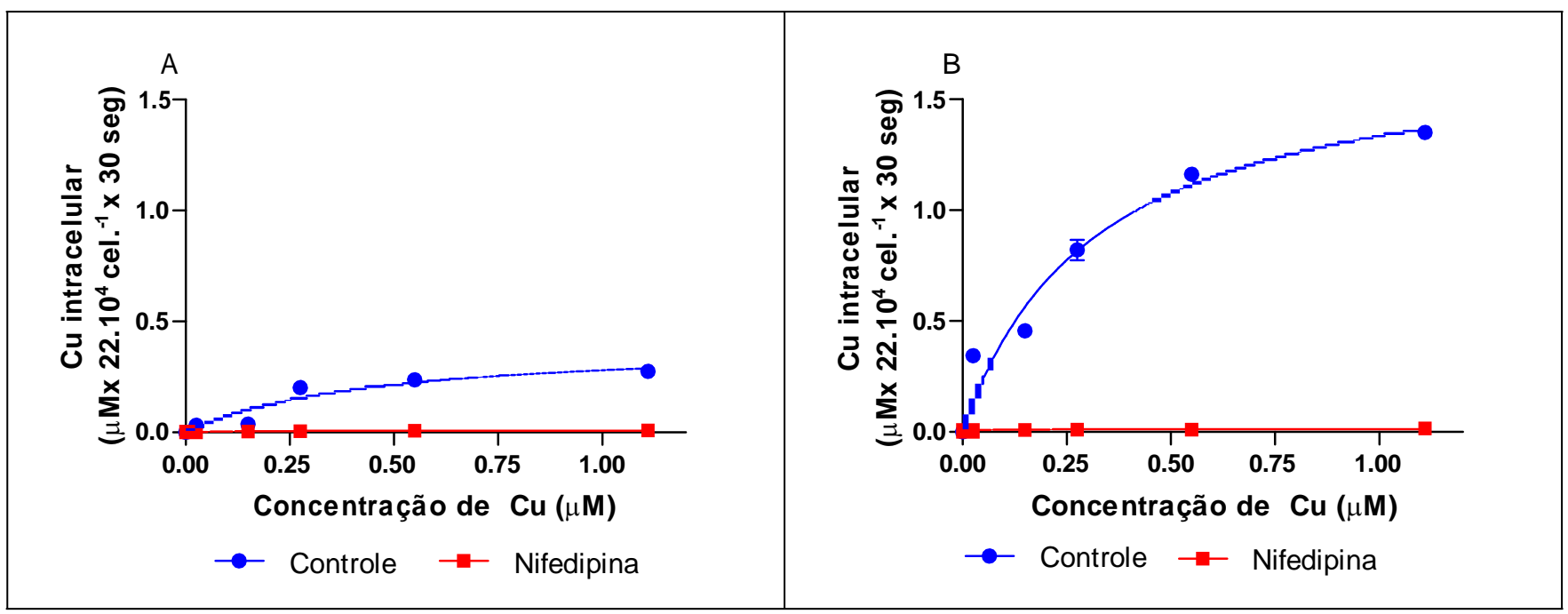

Figura 4. Transporte de cobre nas células epiteliais de brânquias de Ucides cordatus representando a concentração intracelular de $\mathrm{Cu}^{+}$em relação ao aumento crescente de cobre externo na forma de $\mathrm{CuCl}_{2}(0,025 ; 0,150 ; 0,275 ; 0,55 ; 1.110 \mu \mathrm{M})$, onde $(\mathrm{A})$ representa a comparação da concentração intracelular de cobre ( $\mu \mathrm{M} \times 22.10^{4} \mathrm{cel}^{-1} \times 30 \mathrm{seg}$ ) nas brânquias anteriores controle e incubadas em $100 \mu \mathrm{M}$ de nifedipina ao longo dos 300 segundos de leitura da tomada de cobre; e (B) representa a comparação da concentração intracelular de cobre $\left(\mu \mathrm{M} \times 22.10^{4} \mathrm{cel}^{-1} \times 30\right.$ seg) nas brânquias posteriores controle e incubadas em $100 \mu \mathrm{M}$ de nifedipina ao longo dos 300 segundos de leitura da tomada de cobre $(n=4)$. 
Na figura 5 é possível observar a nítida redução da tomada de cobre na presença de verapamil, com reduções que atingem diferenças estatísticas de $p<0,001$ e $p<0,05$ respectivamente para células de brânquias anteriores e posteriores, enquanto que os valores de $\mathrm{Km}$ não apresentaram diferença significativa quando comparadas as brânquias anteriores incubadas ou não em verapamil, porém quando os valores de $\mathrm{Km}$ par as brânquias posteriores foram comparados, houve aumento da afinidade quando na presença de verapamil apresentando $p<0,01$. Assim como os resultados para nifedipina, as células de brânquias posteriores incubadas em verapamil apresentaram redução substancialmente maior do que para as células anteriores, uma vez que a entrada de cobre nas células posteriores tenha sido amplamente maior do que nas anteriores.

Tabela 5. Valores de Vmax $(\mu \mathrm{M})$ e $\mathrm{Km}(\mu \mathrm{M})$ para células de brânquias anteriores e posteriores de Ucides cordatus (média $\pm \mathrm{EP} ; \mathrm{N}=4$ ), onde os asteriscos indicam diferença estatística significativa entre os parâmetros cinéticos apresentados para as células de brânquias (ANOVA, teste T).

\begin{tabular}{ccc}
\hline Células & Vmax (uM) & Km (uM) \\
\hline Anterior & $0,4045 \pm 0,1196$ & $0,4416 \pm 0,0299$ \\
Anterior + Verapamil & $0,0830 \pm 0,0154 * *$ & $0,4690 \pm 0,1954$ \\
Posterior & $1,7550 \pm 0,2711$ & $0,3152 \pm 0,0267$ \\
Posterior + Verapamil & $0,2020 \pm 0,0193 *$ & $0,0647 \pm 0,0130 * *$ \\
\hline
\end{tabular}

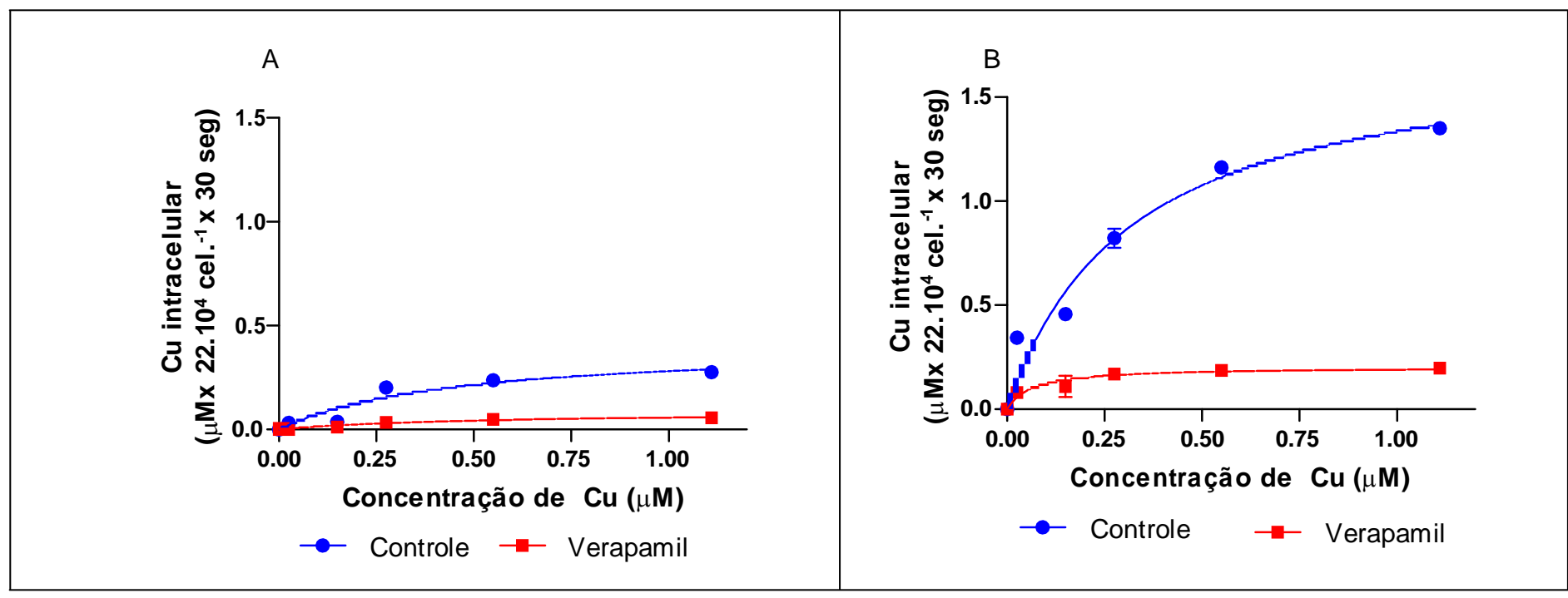

Figura 5. Transporte de cobre nas células epiteliais de brânquias de Ucides cordatus representando a concentração intracelular de $\mathrm{Cu}^{+}$em relação ao aumento crescente de cobre externo na forma de $\mathrm{CuCl}_{2}$ $(0,025 ; 0,150 ; 0,275 ; 0,55 ; 1.110 \mu \mathrm{M})$, onde $(A)$ representa a comparação da concentração intracelular de cobre $\left(\mu \mathrm{M} \times 22.10^{4} \mathrm{cel}^{-1} \times 30 \mathrm{seg}\right)$ nas brânquias anteriores controle e incubadas em $50 \mu \mathrm{M}$ de verapamil ao longo dos 300 segundos de leitura da tomada de cobre; e (B) representa a comparação da concentração intracelular de cobre $\left(\mu \mathrm{M} \times 22.10^{4} \mathrm{cel}^{-1} \times 30 \mathrm{seg}\right)$ nas brânquias posteriores controle e incubadas em $50 \mu \mathrm{M}$ de verapamil ao longo dos 300 segundos de leitura da tomada de cobre $(n=4)$. 
A figura 6 é apresentada com valores de unidade arbitrária de fluorescência (como citado na seção de material e métodos) sendo possível observar que a incubação em amiloride, tanto para as brânquias anteriores quanto para as posteriores, inibiu a entrada de cobre drasticamente, tendo valores de entrada de cobre nestas células muito altos . Nota-se ainda que a inibição da entrada de cobre seja levemente superior nas brânquias posteriores em comparação com o obtido para as brânquias anteriores, com valores de $p<0,001$ quando comparados os valores de Vmax das brânquias anteriores e posteriores e é possível observar também que com a presença do inibidor, a afinidade do cobre pelas proteínas de membrana foi amplamente elevada, já que os valores de $\mathrm{Km}$ são inversamente proporcionais à afinidade do íon em questão por proteínas de membrana, com $p<0,01$ e $p<0,05$ respectivamente para brânquias anteriores e posteriores.

Tabela 6. Valores de Vmax $(\mu \mathrm{M})$ e $\mathrm{Km}(\mu \mathrm{M})$ para células de brânquias anteriores e posteriores de Ucides cordatus (média $\pm E P ; N=4$ ), onde não foi observada diferença estatística significativa entre os parâmetros cinéticos apresentados para as células de brânquias (ANOVA, teste T).

\begin{tabular}{ccl}
\hline Células & \multicolumn{1}{c}{ Vmax $(\mu \mathrm{M})$} & \multicolumn{1}{c}{$\mathrm{Km}(\mu \mathrm{M})$} \\
\hline Anterior & $820,50 \pm 87,44$ & $0,7085 \pm 0,1462$ \\
Anterior + Amiloride & $9357,00 \pm 21,97 * * *$ & $0,0076 \pm 0,0002 * *$ \\
Posterior & $1366,00 \pm 266,00$ & $0,7677 \pm 0,2823$ \\
Posterior + Amiloride & $13310,00 \pm 143,00 * * *$ & $0,0110 \pm 0,0010^{*}$ \\
\hline
\end{tabular}

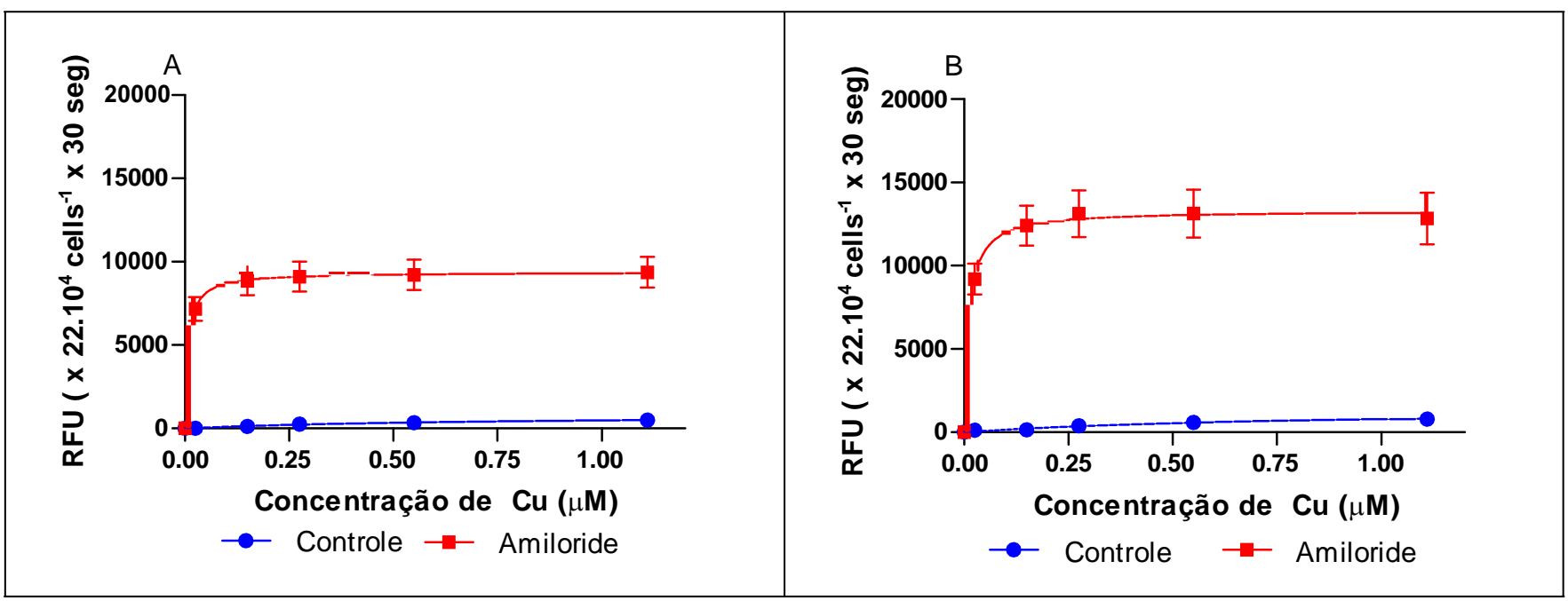

Figura 6. Transporte de cobre nas células epiteliais de brânquias de Ucides cordatus representando a concentração intracelular de $\mathrm{Cu}^{+}$em relação ao aumento crescente de cobre externo na forma de $\mathrm{CuCl}_{2}(0,025 ; 0,150 ; 0,275 ; 0,55 ; 1.110 \mu \mathrm{M})$ onde (A) representa a comparação da concentração intracelular de cobre em unidade arbitrária de fluorescência (RFU x $22.10^{4} \mathrm{cel}^{-1} \times 30 \mathrm{seg}$ ) nas brânquias anteriores controle e incubadas em $200 \mu \mathrm{M}$ de amiloride ao longo dos 300 segundos de leitura da tomada de cobre; e (B) representa a comparação da concentração intracelular de cobre em unidade arbitrária de fluorescência (RFU x $22.10^{4} \mathrm{cel}^{-1}$ × $30 \mathrm{seg}$ ) nas brânquias posteriores controle e incubadas em $200 \mu \mathrm{M}$ de amiloride ao longo dos 300 segundos de leitura da tomada de cobre $(n=4)$. 
Nas figuras 7A e 7B observa-se o efeito da ouabaína e é demonstrado que esta droga atua diretamente na redução da entrada de cobre nestas células, onde houve redução de mais de $50 \%$ em relação às células das brânquias anteriores e de $7 x$ nas brânquias posteriores, com $p<0,01$ e $p<0,001$, respectivamente. Já em relação aos valores de afinidade do metal $(\mathrm{Km})$ pelas proteínas de membrana, não houve diferença significativa na comparação das brânquias anteriores, porém para as brânquias posteriores, na presença de ouabaína houve aumento dos valores de $\mathrm{Km}$, com valor de $\mathrm{p}<0,01$.

Tabela 7. Valores de Vmax $(\mu \mathrm{M})$ e $\mathrm{Km}(\mu \mathrm{M})$ para células de brânquias anteriores e posteriores de Ucides cordatus (média $\pm E P ; N=4$ ), onde não foi observada diferença estatística significativa entre os parâmetros cinéticos apresentados para as células de brânquias (ANOVA, teste T).

\begin{tabular}{ccc}
\hline Células & Vmax (uM) & Km (uM) \\
\hline Anterior & $0,4045 \pm 0,1196$ & $0,4416 \pm 0,2992$ \\
\hline Anterior + Ouabaína & $0,1573 \pm 0,0282 * *$ & $0,2404 \pm 0,1247$ \\
Posterior & $1,7550 \pm 0,2711$ & $0,3152 \pm 0,1267$ \\
\hline Posterior + Ouabaína & $0,2508 \pm 0,0746 * * *$ & $1,1580 \pm 0,5677 * *$ \\
\hline
\end{tabular}

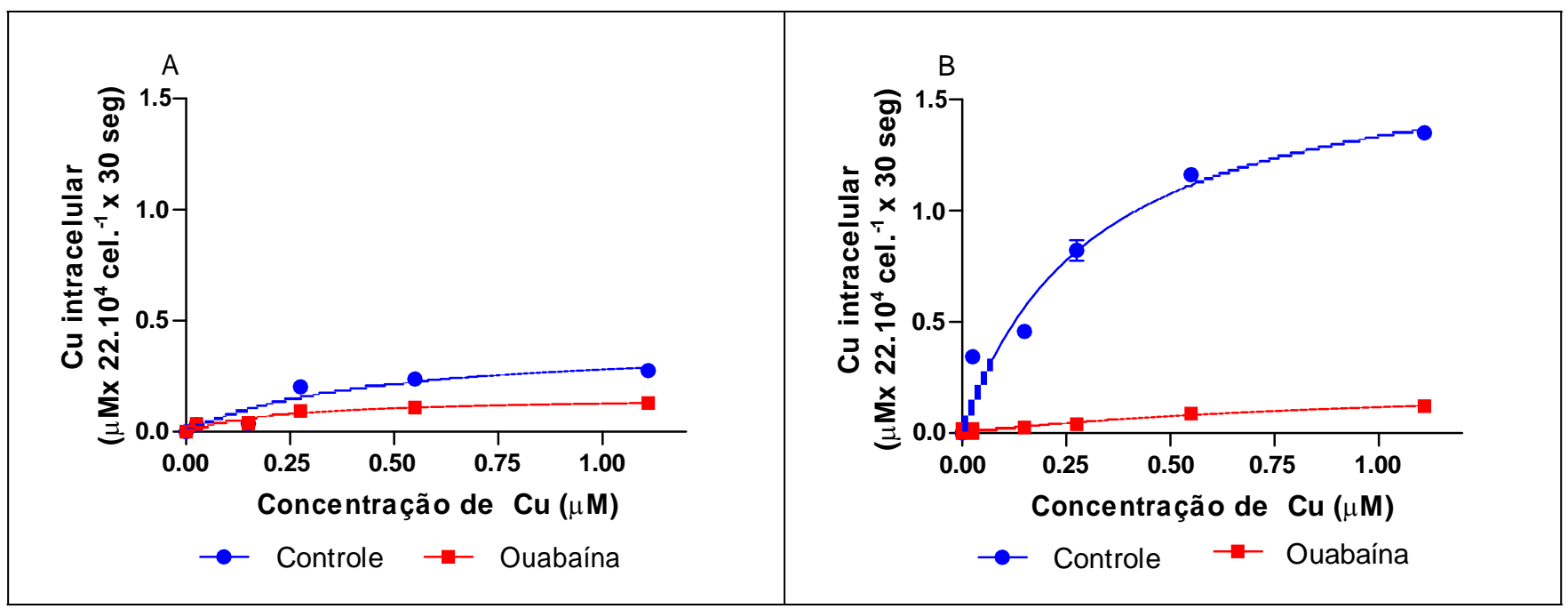

Figura 7. Transporte de cobre nas células epiteliais de brânquias de Ucides cordatus representando a concentração intracelular de $\mathrm{Cu}^{+}$em relação ao aumento crescente de cobre externo na forma de $\mathrm{CuCl}_{2}(0,025 ; 0,150 ; 0,275 ; 0,55 ; 1.110 \mu \mathrm{M})$ onde (A) representa a comparação da concentração intracelular de cobre $\left(\mu \mathrm{M} \times 22.10^{4} \mathrm{cel}^{-1} \times 30 \mathrm{seg}\right)$ nas brânquias anteriores controle e incubadas em $2 \mathrm{mM}$ de ouabaína ao longo dos 300 segundos de leitura da tomada de cobre; e (B) representa a comparação da concentração intracelular de cobre $\left(\mu \mathrm{M} \times 22.10^{4} \mathrm{cel}^{-1} \times 30 \mathrm{seg}\right)$ nas brânquias posteriores controle e incubadas em $2 \mathrm{mM}$ de ouabaína ao longo dos 300 segundos de leitura da tomada de cobre $(n=4)$. 
Para a figura $8 \mathrm{~A}$ foi observada redução da velocidade da entrada de cobre na presença do inibidor KB-R 7943 apresentando diferença estatística com $p<0,01$, assim como se obteve valor de $p<0,001$ para as brânquias posteriores que apresentaram redução mais acentuada, enquanto que o valor de Km foi reduzido na presença de KB-R 7943 nas brânquias anteriores com diferença estatística de $p<0,05$, enquanto que para as brânquias posteriores, a presença ou não do inibidor não alterou a afinidade do cátion às proteínas de membrana, uma vez que não houve diferença estatística significativa para esta comparação, com p>0,05.

Tabela 8. Valores de Vmax $(\mu \mathrm{M})$ e $\mathrm{Km}(\mu \mathrm{M})$ para células de brânquias anteriores e posteriores de Ucides cordatus (média $\pm \mathrm{EP} ; \mathrm{N}=4$ ), onde os asteriscos indicam diferença estatística significativa entre os parâmetros cinéticos apresentados para as células de brânquias (ANOVA, teste T).

\begin{tabular}{cll}
\hline Células & \multicolumn{1}{c}{ Vmax (uM) } & Km (uM) \\
\hline Anterior & $0,4045 \pm 0,1196$ & $0,4416 \pm 0,2992$ \\
Anterior + KB-R 7943 & $0,1332 \pm 0,0164 * *$ & $0,0757 \pm 0,0435^{*}$ \\
Posterior & $1,7550 \pm 0,2711$ & $0,3152 \pm 0,1267$ \\
Posterior + KB-R 7943 & $0,0711 \pm 0,0151^{* * *}$ & $0,2285 \pm 0,1440$ \\
\hline
\end{tabular}

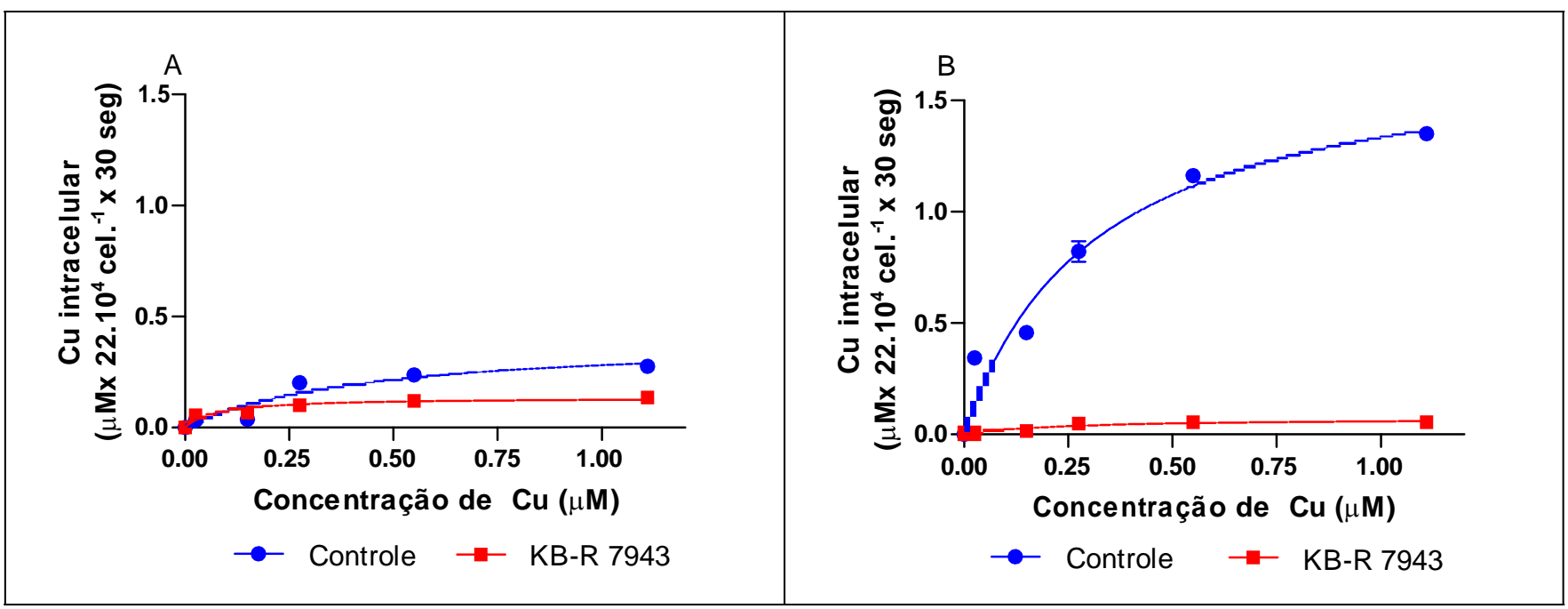

Figura 8. Transporte de cobre nas células epiteliais de brânquias de Ucides cordatus representando a concentração intracelular de $\mathrm{Cu}^{+}$em relação ao aumento crescente de cobre externo na forma de $\mathrm{CuCl}_{2}(0,025 ; 0,150 ; 0,275 ; 0,55 ; 1.110 \mu \mathrm{M})$ onde (A) representa a comparação da concentração intracelular de cobre $\left(\mu \mathrm{M} \times 22.10^{4} \mathrm{cel}^{-1} \times 30 \mathrm{seg}\right)$ nas brânquias anteriores controle e incubadas em $20 \mu \mathrm{M}$ de KB-R 7943 ao longo dos 300 segundos de leitura; e (B) representa a comparação da concentração intracelular de cobre ( $\left.\mu \mathrm{M} \times 22.10^{4} \mathrm{cel}^{-1} \times 30 \mathrm{seg}\right)$ nas brânquias posteriores controle $\mathrm{e}$ incubadas em $20 \mu \mathrm{M}$ de KB-R 7943 ao longo dos 300 segundos de leitura da tomada de cobre $(n=4)$. 
Na figura 9 é possível observar a inibição que a incubação em ortovanadato de sódio (vanadato) causou na cinética de entrada de cobre nas células branquiais e esta inibição é mais acentuada nas brânquias posteriores, porém em ambos os tipos celulares houve diferença estatística significativa, com $p<0,05$ e $p<0,001$ respectivamente para brânquias anteriores e posteriores, porém somente nas brânquias posteriores foi observada diferença estatística nos valores de $\mathrm{Km}$, com $\mathrm{p}<0,01$ e as células incubadas em vanadato apresentaram redução da afinidade do cobre pelas proteínas de membrana, já que para as brânquias posteriores houve aumento do valor de $\mathrm{Km}$.

Tabela 9. Valores de Vmax ( $\mu \mathrm{M})$ e $\mathrm{Km}(\mu \mathrm{M})$ para células de brânquias anteriores e posteriores de Ucides cordatus (média $\pm \mathrm{EP} ; \mathrm{N}=4$ ), onde os asteriscos indicam diferença estatística significativa entre os parâmetros cinéticos apresentados para as células de brânquias (ANOVA, teste T).

\begin{tabular}{ccc}
\hline Células & \multicolumn{1}{c}{ Vmax (uM) } & Km (uM) \\
\hline Anterior & $0,4045 \pm 0,1196$ & $0,4416 \pm 0,2992$ \\
Anterior + Vanadato & $0,1509 \pm 0,0123 *$ & $0,1797 \pm 0,0476$ \\
Posterior & $1,7550 \pm 0,2711$ & $0,3152 \pm 0,1267$ \\
Posterior + Vanadato & $0,2849 \pm 0,0549 * * *$ & $0,8577 \pm 0,3006 * *$ \\
\hline
\end{tabular}
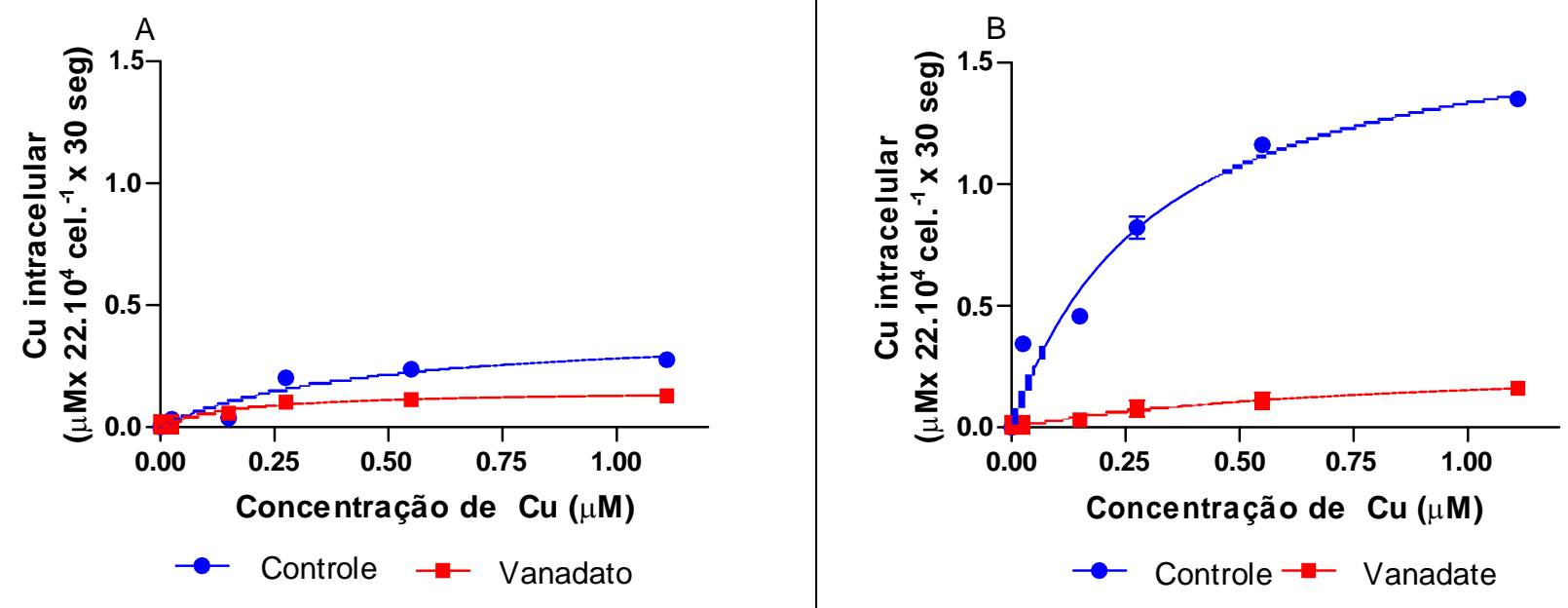

Figura 9. Transporte de cobre nas células epiteliais de brânquias de Ucides cordatus representando a concentração intracelular de $\mathrm{Cu}^{+}$em relação ao aumento crescente de cobre externo na forma de $\mathrm{CuCl}_{2}$ $(0,025 ; 0,150 ; 0,275 ; 0,55 ; 1.110 \mu \mathrm{M})$ onde $(A)$ representa a comparação da concentração intracelular de cobre $\left(\mu \mathrm{M} \times 22.10^{4} \mathrm{cel}^{-1} \times 30 \mathrm{seg}\right)$ nas brânquias anteriores controle e incubadas em $20 \mathrm{mM}$ de ortovanadato de sódio (vanadato) ao longo dos 300 segundos de leitura da tomada de cobre; e (B) representa a comparação da concentração intracelular de cobre $\left(\mu \mathrm{M} \times 22.10^{4} \mathrm{cel}^{-1} \times 30 \mathrm{seg}\right)$ nas brânquias posteriores controle e incubadas em $20 \mathrm{mM}$ de ortovanadato de sódio (vanadato) ao longo dos 300 segundos de leitura da tomada de cobre $(n=4)$. 
Na figura 10 é nítido o aumento da concentração de cobre intracelular tanto nas células anteriores quanto nas posteriores, embora nas brânquias anteriores os valores de cobre intracelular tenham sido relativamente superiores. Ao contrário do que foi observado para a concentração de cobre em tempo real das células do grupo controle, na presença de ATP e $\mathrm{CuCl}_{2}$, a entrada de cobre não foi proporcional à presença de cobre no meio extracelular, onde a que se elevou e manteve mais constante foi a solução de ATP contendo 0,150 $\mu \mathrm{M}$ de $\mathrm{CuCl}_{2}$, porém a solução de ATP com $0,275 \mu \mathrm{M}$ de $\mathrm{CuCl}_{2}$ foi a que apresentou maior concentração de cobre intracelular, mas após aproximadamente 1 minuto tal concentração voltou ao nível basal previamente encontrado. Já as brânquias anteriores apresentaram níveis de $\mathrm{Cu}^{+}$intracelular livre mais baixos do que as brânquias posteriores, porém foram mais constantes ao longo do experimento, onde houve aumento após a injeção da solução de ATP e $\mathrm{CuCl}_{2}$ e manteve-se assim, apresentando mais uma vez as diferenças funcionais entre os dois tipos branquiais.

Para efeitos estatísticos, foram realizadas comparações entre o último ponto de registro do cobre intracelular (300 segundos) e o primeiro segundo após a injeção das diversas soluções de ATP e $\mathrm{CuCl}_{2}$ (30 segundos) e obteve-se valores de $p<0,01$ para a concentração de 0,025 $\mu \mathrm{M}$ de $\mathrm{CuCl}_{2}$ para ambas as brânquias, $\mathrm{p}<0,001$ para a segunda concentração $0,150 \mu \mathrm{M}$ de $\mathrm{CuCl}_{2}$ para brânquias anteriores e posteriores, assim como na última concentração utilizada que foi de $1,110 \mu \mathrm{M}$ de $\mathrm{CuCl}_{2}$. Já para a concentração utilizada de $0,275 \mu \mathrm{M}$ de $\mathrm{CuCl}_{2}$ foi encontrado $p<0,05$ e $p<0,01$ respectivamente para brânquias anteriores e posteriores, enquanto que para a concentração de $0,55 \mu \mathrm{M}$ de $\mathrm{CuCl}_{2}$ não houve diferença estatística $(p>0,05)$ para as brânquias anteriores, enquanto que obteve-se valor de $p<0,05$ para as brânquias posteriores. 


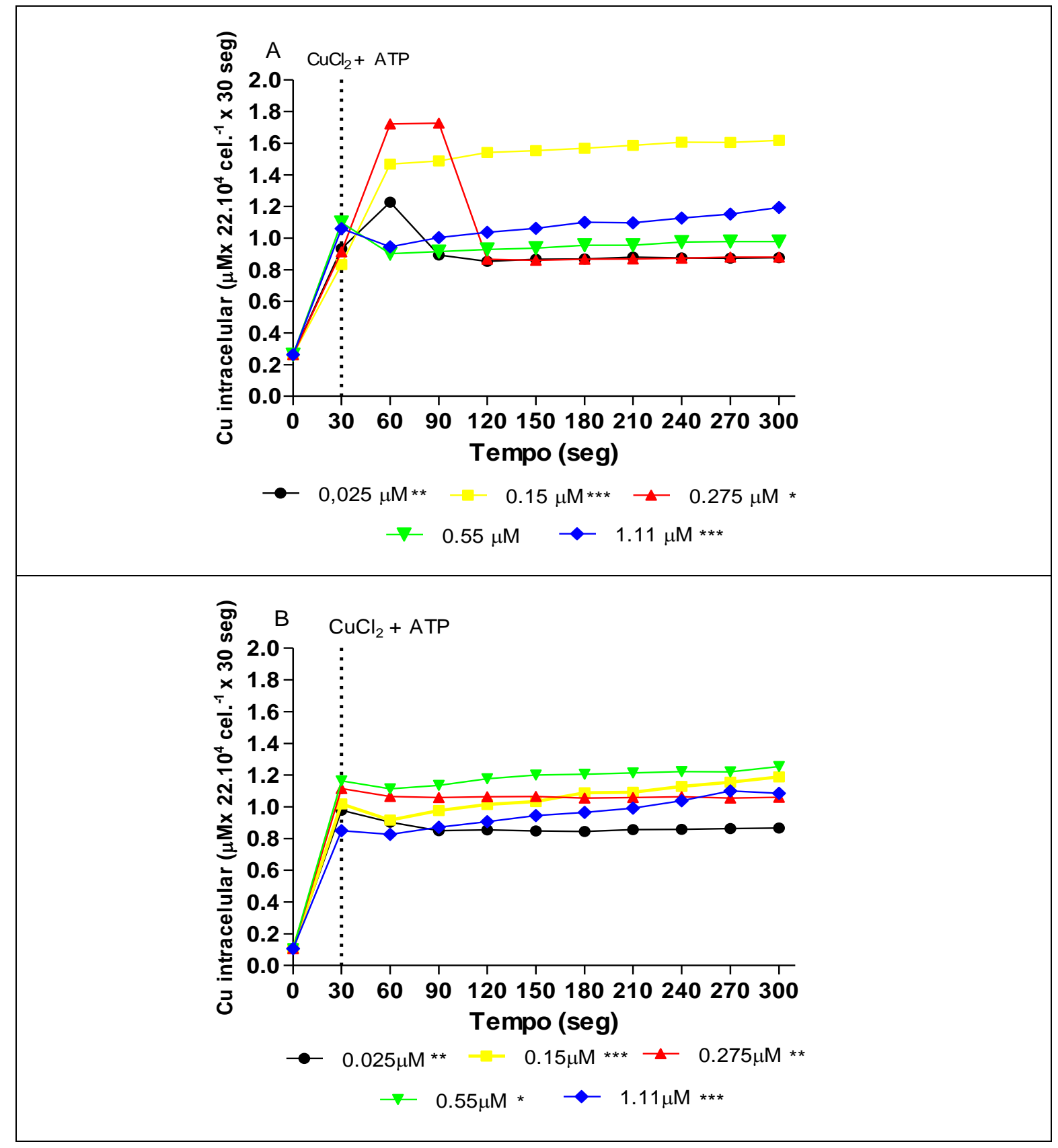

Figura 10. Transporte de cobre nas células epiteliais de brânquias de Ucides cordatus representando a concentração intracelular de $\mathrm{Cu}$ em relação ao aumento crescente de cobre externo na forma de $\mathrm{CuCl}_{2}$ $(0,025 ; 0,150 ; 0,275 ; 0,55 ; 1.110 \mu \mathrm{M})$ onde $(\mathrm{A})$ apresenta a entrada de cobre em tempo real nas células anteriores, onde tal entrada foi obtida através da média de cada 30 segundos de leitura no espectrofluorímetro após injeção de soluções crescentes de $\mathrm{CuCl}_{2}$ e $1,5 \mathrm{mM}$ de ATP; (B) apresenta a entrada de cobre em tempo real nas células posteriores, onde tal entrada foi obtida através da média de cada 30 segundos de leitura no espectrofluorímetro após injeção de soluções crescentes de $\mathrm{CuCl}_{2}$ e 1,5 $\mathrm{mM}$ de ATP $(n=4)$. 
A figura 11 apresenta os efeitos da injeção de crescentes concentrações de cobre após as células serem incubadas em cafeína. A figura 11A apresenta o influxo de cobre sendo aumentado na presença de cafeína nas brânquias anteriores para todas as concentrações e após os 300 segundos de leitura, os valores retornaram para pontos próximos aos iniciais, obtendo-se diferença estatística quando comparados os valores finais com os iniciais para todas as concentrações de cobre utilizadas, com valor de $p<0,05$ para as concentrações 0,025 e $0,55 \mu \mathrm{M}, \mathrm{p}<0,01$ para as concentrações 0,15 e 1,11 $\mu \mathrm{M}$ e $p<0,001$ para a concentração 0,275 $\mu \mathrm{M}$ de $\mathrm{CuCl}_{2}$ e vale ressaltar que esta foi a concentração utilizada que mais apresentou variação da entrada de cobre ao longo dos 300 segundos.

Já para as brânquias posteriores (referente a figura 11B), o aumento da concentração de cobre intracelular foi ainda maior do que nas brânquias anteriores, quando os valores de $\mathrm{Cu}^{+}$intracelular livre chegaram próximos a $3 \mu \mathrm{M}$. Assim como observado nas brânquias anteriores, obteve-se diferença estatisticamente significativa para todas as concentrações de cobre externo adicionadas, com valor de $p<0,01$ para as concentrações 0,025 e 0,55 $\mu \mathrm{M}$ e $p<0,001$ para as demais concentrações $(0,15 ; 0,275 ; 1,11 \mu \mathrm{M})$ que apresentaram maior diferença entre os valores iniciais e finais. 


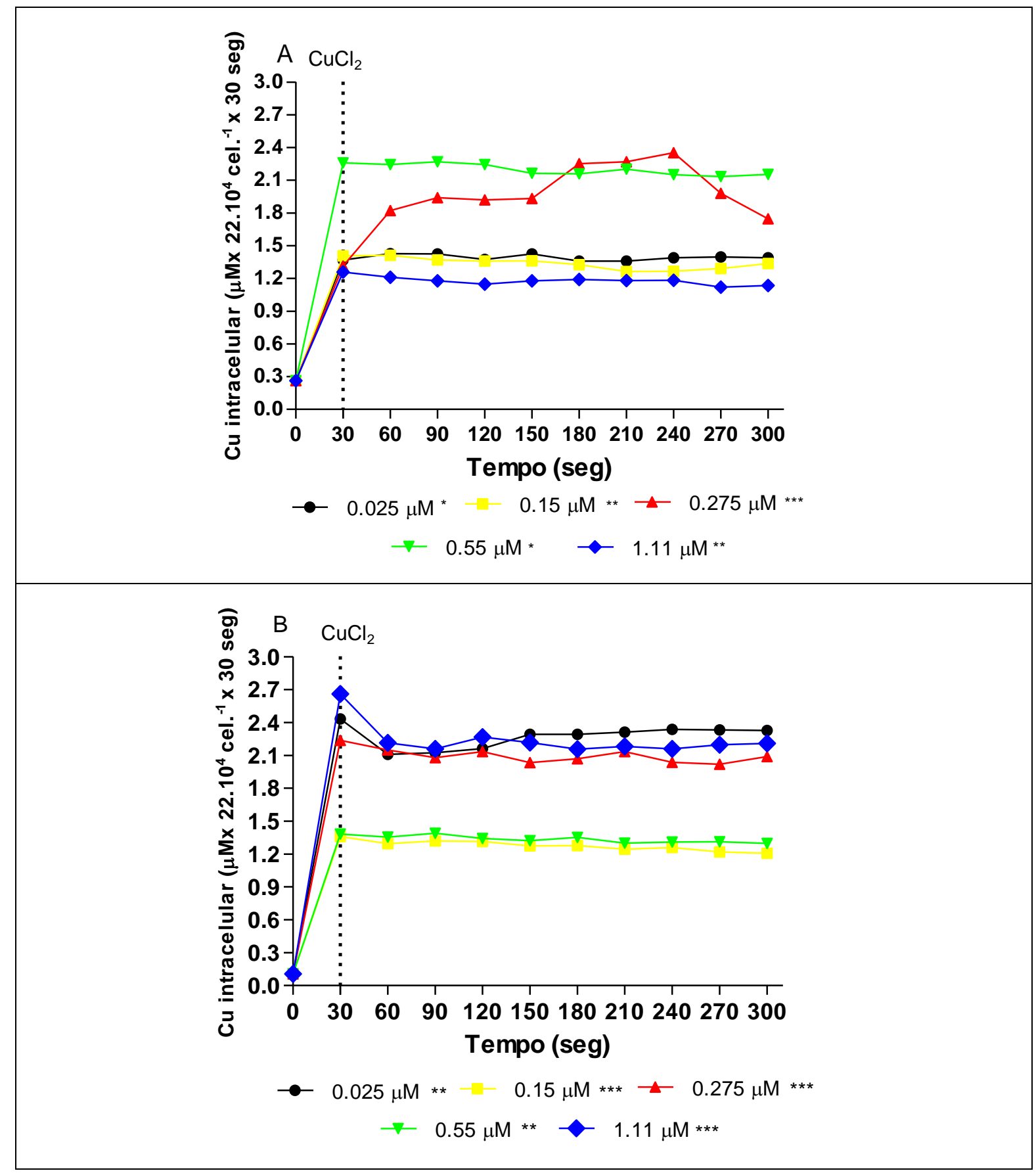

Figura 11. Transporte de cobre nas células epiteliais de brânquias de Ucides cordatus representando a concentração intracelular de $\mathrm{Cu}$ em relação ao aumento crescente de cobre externo na forma de $\mathrm{CuCl}_{2}$ $(0,025 ; 0,150 ; 0,275 ; 0,55 ; 1.110 \mu \mathrm{M})$ onde $(A)$ apresenta a entrada de cobre em tempo real nas células anteriores, onde tal entrada foi obtida através da média de cada 30 segundos de leitura no espectrofluorímetro após incubação em $20 \mu \mathrm{M}$ cafeína; (B) apresenta a entrada de cobre em tempo real nas células posteriores, onde tal entrada foi obtida através da média de cada 30 segundos de leitura no espectrofluorímetro após incubação em $20 \mu \mathrm{M}$ cafeína (n=4). 
A figura 12 demonstra a tomada de cobre foi reduzida em ambos os tipos celulares das brânquias, porém quando se observa os resultados obtidos para os valores de $\mathrm{Km}$, este é reduzido tanto nas brânquias anteriores quanto nas posteriores, onde é observada diferença estatística significativa com $\mathrm{p}<0,05$ tanto para brânquias anteriores quanto para as posteriores, enquanto que para a comparação dos valores de Vmax, não foram obtidos valores de $p$ estatisticamente significativos.

Tabela 10. Valores de $V \max (\mu \mathrm{M})$ e $\mathrm{Km}(\mu \mathrm{M})$ para células de brânquias anteriores e posteriores de Ucides cordatus (média $\pm \mathrm{EP} ; \mathrm{N}=4$ ), onde os asteriscos indicam diferença estatística significativa entre os parâmetros cinéticos apresentados para as células de brânquias (ANOVA, teste T).

\begin{tabular}{ccl}
\hline Células & Vmax $(\mathrm{uM})$ & \multicolumn{1}{c}{$\mathrm{Km}(\mathrm{uM})$} \\
\hline Anterior & $820.50 \pm 87.44$ & $0.7085 \pm 0.1462$ \\
Anterior + Bafilomicina & $735.40 \pm 49.90$ & $0.0199 \pm 0.0095^{*}$ \\
Posterior & $1366 \pm 266$ & $0.7677 \pm 0.2823$ \\
Posterior + Bafilomicina & $1706 \pm 104$ & $0.0179 \pm 0.0080^{*}$ \\
\hline
\end{tabular}

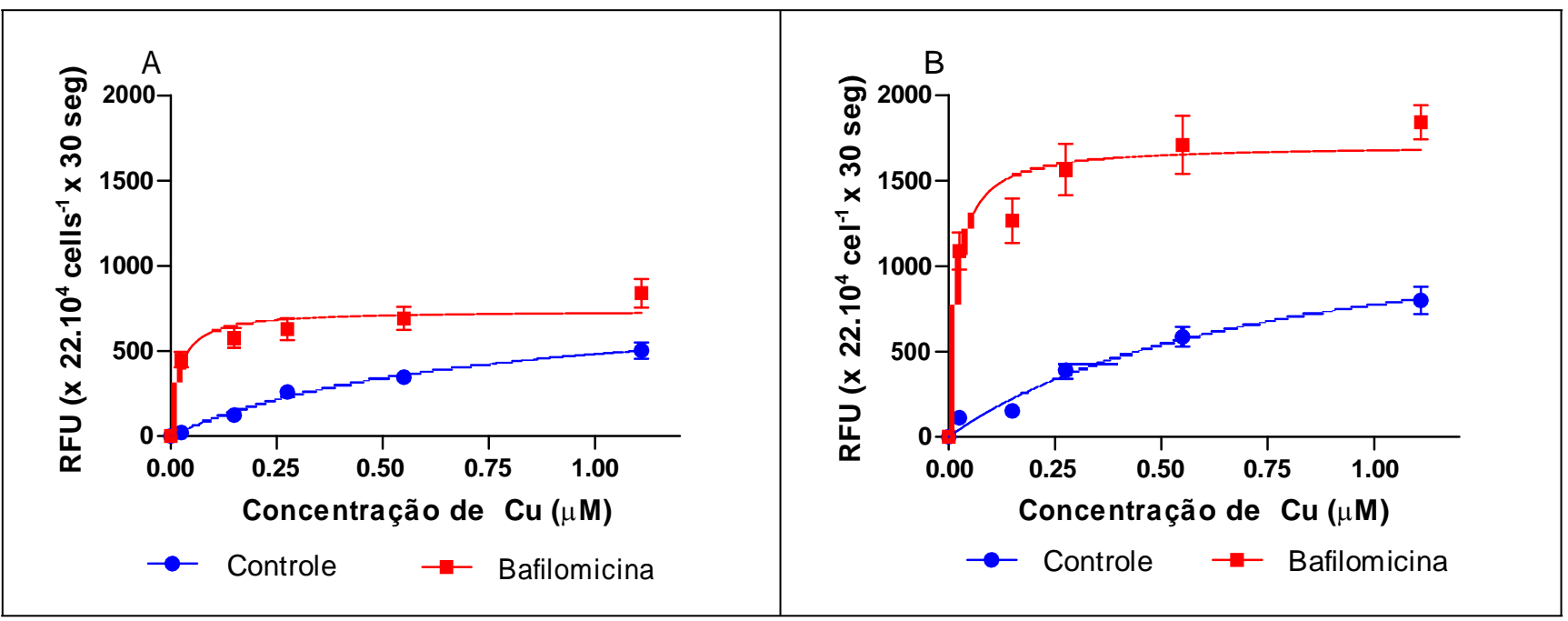

Figura 12. Transporte de cobre nas células epiteliais de brânquias de Ucides cordatus representando a concentração intracelular de $\mathrm{Cu}^{+}$em relação ao aumento crescente de cobre externo na forma de $\mathrm{CuCl}_{2}$ $(0,025 ; 0,150 ; 0,275 ; 0,55 ; 1.110 \mu \mathrm{M})$ onde $(A)$ representa a comparação da concentração intracelular de cobre ( $\left.\mu \mathrm{M} \times 22.10^{4} \mathrm{cel}^{-1} \times 30 \mathrm{seg}\right)$ nas brânquias anteriores controle e incubadas em $2 \mathrm{mM}$ de ouabaína ao longo dos 300 segundos de leitura da tomada de cobre; e (B) representa a comparação da concentração intracelular de cobre $\left(\mu \mathrm{M} \times 22.10^{4} \mathrm{cel}^{-1} \times 30 \mathrm{seg}\right)$ nas brânquias posteriores controle $\mathrm{e}$ incubadas em $2 \mathrm{mM}$ de ouabaína ao longo dos 300 segundos de leitura da tomada de cobre $(n=4)$. 


\section{Hepatopâncreas}

A figura 13A apresenta a concentração intracelular de cobre nas células $E$, que são menos densas, apresentando $\operatorname{Vmax}$ de 3,1120 $\mu \mathrm{M}$, sendo esta bastante próxima dos valores de velocidade máxima de entrada do cobre aos valores obtidos nas figuras $13 \mathrm{~B}$ e $13 \mathrm{C}$, que representam populações tanto das células $R$ quanto das células $F$, com Vmax de 3,7160 e 3,9530 $\mu \mathrm{M}$, respectivamente. Já as células $\mathrm{B}$, apresentam a velocidade de entrada mais baixa $(2,3400 \mu \mathrm{M})$ em relação às demais células, sendo esta a mais densa entre os quatro tipos celulares, sendo que este tipo celular apresenta valor de $p<0,05$ quando comparada com os três outros tipos celulares. No entanto, quando comparamos os valores de Km que indicam a afinidade do cobre pelos canais, trocadores e demais proteínas das células, obteve-se maior afinidade pelas células $E$ com $\mathrm{Km}$ de $0,0050 \mu \mathrm{M}$, enquanto que as células $B$ apresentaram a menor afinidade pelas proteínas celulares, onde foi obtida diferença estatística com $p<0,01$ quando comparadas as células $R / F(1)$ com as demais e $p<0,001$ quando da comparação das células $B$ com as células $E$ e as duas populações de células $R / F$.

Tabela 11. Valores de Vmax $(\mu \mathrm{M})$ e $K m(\mu M)$ para células de hepatopâncreas de Ucides cordatus (média $\pm \mathrm{EP} ; \mathrm{N}=4$ ), onde os asteriscos indicam diferença estatística significativa entre os parâmetros cinéticos apresentados para as células de brânquias (ANOVA, teste T).

\begin{tabular}{ccl}
\hline Células & \multicolumn{1}{c}{ Vmax $(\mu \mathrm{M})$} & \multicolumn{1}{c}{$\mathrm{Km}(\mu \mathrm{M})$} \\
\hline Células $\mathrm{E}$ & $3,1120 \pm 0,1285$ & $0,0050 \pm 0,0030$ \\
Células $\mathrm{R} / \mathrm{F}(\mathbf{1})$ & $3,7160 \pm 0,1547$ & $0,0142 \pm 0,0047^{* *}$ \\
Células R/F(2) & $3,9530 \pm 0,2084$ & $0,0077 \pm 0,0045$ \\
Células B & $2,3400 \pm 0,0845^{*}$ & $0,0330 \pm 0,0164^{* * *}$ \\
\hline
\end{tabular}




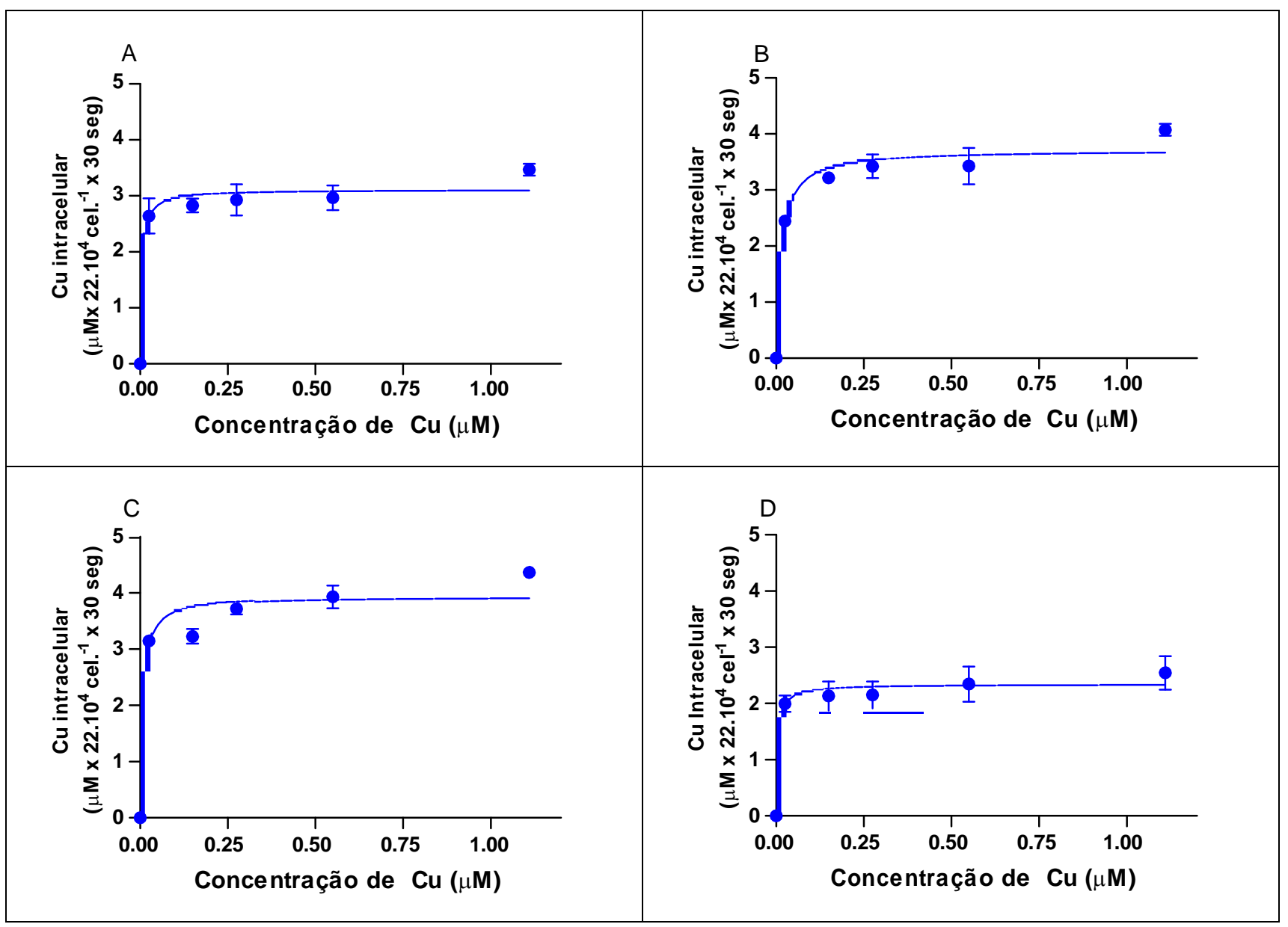

Figura 13. Transporte de cobre nas células epiteliais de hepatopâncreas de Ucides cordatus representando a concentração intracelular de $\mathrm{Cu}$ em relação ao aumento crescente de cobre externo na forma de $\mathrm{CuCl}_{2}(0,025 ; 0,150 ; 0,275 ; 0,55 ; 1.110 \mu \mathrm{M})$ onde (A) representa a comparação da concentração intracelular de cobre $\left(\mu \mathrm{M} \times 22.10^{4} \mathrm{cel}^{-1} \times 30 \mathrm{seg}\right)$ nas células $\mathrm{E}$ do hepatopâncreas ao longo dos 300 segundos de leitura da tomada de cobre; e (B) representa a comparação da concentração intracelular de cobre ( $\mu \mathrm{M} \times 22.10^{4}$ cel $^{-1}$ x $30 \mathrm{seg}$ ) nas células $\mathrm{R} / \mathrm{F}(1)$ do hepatopâncreas ao longo dos 300 segundos de leitura da tomada de cobre; (C) representa a comparação da concentração intracelular de cobre ( $\mu \mathrm{M} \times 22.10^{4} \mathrm{cel}^{-1} \times 30 \mathrm{seg}$ ) nas células $\mathrm{R} / \mathrm{F}(2)$ do hepatopâncreas ao longo dos 300 segundos de leitura da tomada de cobre ; (D) representa a comparação da concentração intracelular de cobre $(\mu \mathrm{M} x$ $22.10^{4} \mathrm{cel}^{-1}$ x $30 \mathrm{seg}$ ) nas células B do hepatopâncreas ao longo dos 300 segundos de leitura da tomada de cobre $(n=4)$. 
A figura 14 traz os resultados obtidos quando as brânquias foram incubadas em cálcio, apresentando dinâmicas bastante semelhantes entre as células $E, R / F(2)$ e $B$, onde o cálcio atua estimulando a entrada de cobre, ao passo que para as células $R / F(1)$, a entrada de cobre na presença ou ausência de cálcio não foi afetada, apresentando valor de p>0,05 para este tipo celular, da mesma maneira que para as células $\mathrm{E}$, que apresentaram valores de Vmax similares entre si, com $\mathrm{p}>0,05$, assim como para a figura 14B.

Já as células $R / F(2)$, da figura $14 C$, apresentaram diferença estatística com valor $p<0,05$, apresentando maior tomada de cobre na presença de cálcio no meio exterior. Da mesma maneira, obteve-se quase o dobro do valor de Vmax quando as células B foram incubadas em cálcio, com ampla participação do cálcio como facilitador da tomada de cobre, com $p<0,001$. Quando analisados os valores de $\mathrm{Km}$, estes foram consideravelmente reduzidos, embora não tenha havido diferença estatística para a comparação entre os dois grupos de células $E$, enquanto que foram obtidos valores de $p<0,01$ para células $R / F(1)$ e (2) e $p<0,05$ para as células blister ou células em "bolha" (células B).

Tabela 12. Valores de $V \max (\mu \mathrm{M})$ e $\mathrm{Km}(\mu \mathrm{M})$ para células de hepatopâncreas de Ucides cordatus (média $\pm \mathrm{EP} ; \mathrm{N}=4$ ), onde os asteriscos indicam diferença estatística significativa entre os parâmetros cinéticos apresentados para as células de brânquias (ANOVA, teste T).

\begin{tabular}{cll}
\hline Células & \multicolumn{1}{c}{ Vmax $(\mu \mathrm{M})$} & $\mathrm{Km}(\mu \mathrm{M})$ \\
\hline Controle Células E & $3,1120 \pm 0,1285$ & $0,0050 \pm 0,0030$ \\
\hline Cálcio Células E & $3,8370 \pm 0,0743$ & $0,0039 \pm 0,0013$ \\
\hline Controle Células R/F(1) & $3,7160 \pm 0,1547$ & $0,0142 \pm 0,0047$ \\
Cálcio Células R/F(1) & $3,6390 \pm 0,1500$ & $0,0052 \pm 0,0031^{* *}$ \\
Controle R/F(2) & $3,9530 \pm 0,2084$ & $0,0077 \pm 0,0045$ \\
\hline Cálcio R/F(2) & $3,6590 \pm 0,1082 *$ & $0,0030 \pm 0,0019 * *$ \\
\hline Controle Células B & $2,3400 \pm 0,0845$ & $0,0330 \pm 0,0164$ \\
Cálcio Células B & $4,0150 \pm 0,2068 * * *$ & $0,0074 \pm 0,0043^{*}$ \\
\hline
\end{tabular}




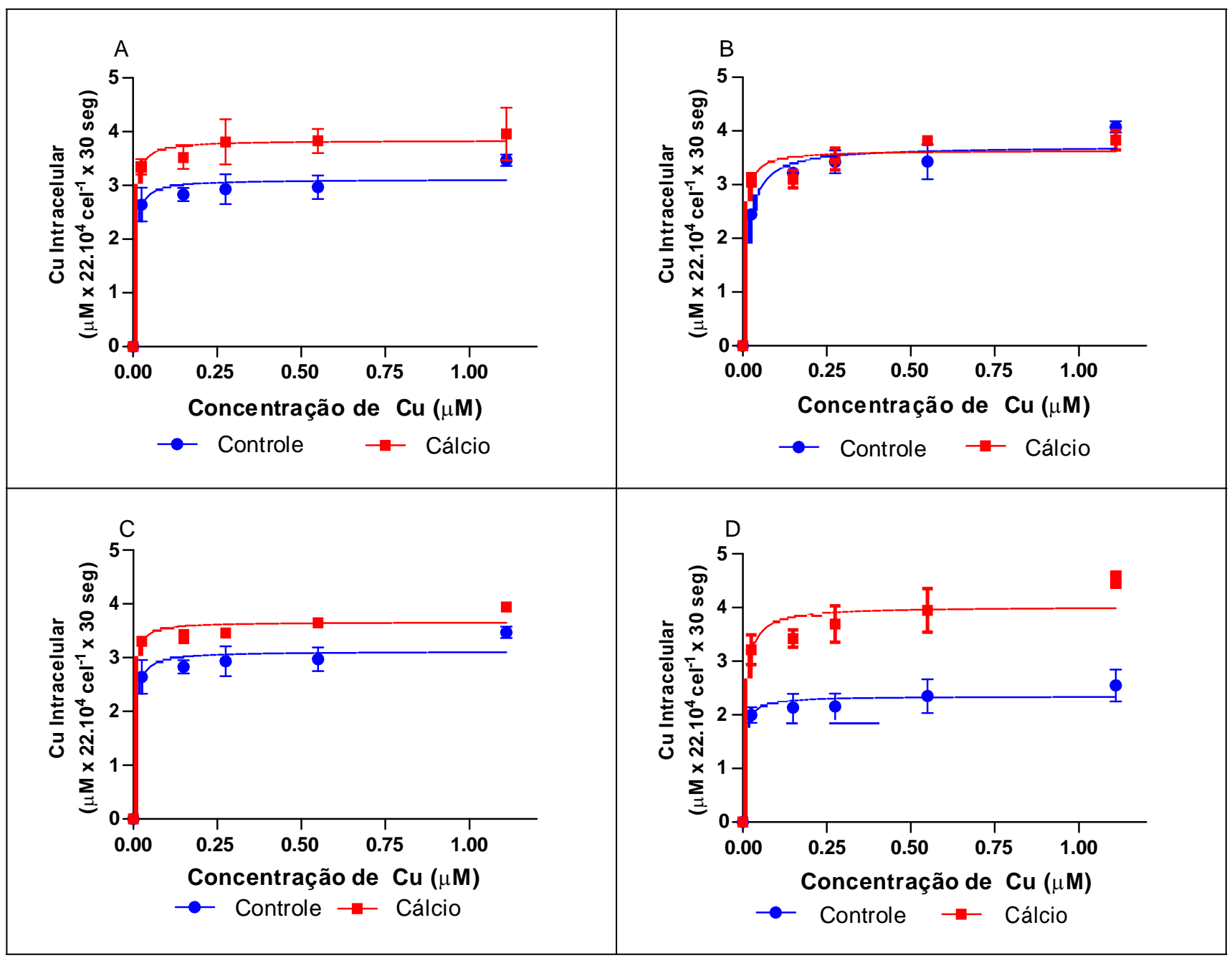

Figura 14. Transporte de cobre nas células epiteliais de hepatopâncreas de Ucides cordatus representando a concentração intracelular de cobre em relação ao aumento crescente de Cu externo na forma de $\mathrm{CuCl}_{2}(0,025 ; 0,150 ; 0,275 ; 0,55 ; 1.110 \mu \mathrm{M})$ onde (A) representa a comparação da concentração intracelular de cobre ( $\mu \mathrm{M} \times 22.10^{4} \mathrm{cel}^{-1} \times 30 \mathrm{seg}$ ) nas células $\mathrm{E}$ do hepatopâncreas ao longo dos 300 segundos de leitura da tomada de cobre incubadas em $20 \mathrm{mM}$ cálcio; e (B) representa a comparação da concentração intracelular de cobre $\left(\mu \mathrm{M} \times 22.10^{4} \mathrm{cel}^{-1} \times 30 \mathrm{seg}\right)$ nas células $\mathrm{R} / \mathrm{F}(1)$ do hepatopâncreas ao longo dos 300 segundos de leitura da tomada de cobre incubadas em 20 mM cálcio; (C) representa a comparação da concentração intracelular de cobre $\left(\mu \mathrm{M} \times 22.10^{4} \mathrm{ce}^{-1} \times 30 \mathrm{seg}\right)$ nas células $R / F(2)$ do hepatopâncreas ao longo dos 300 segundos de leitura da tomada de cobre incubadas em $20 \mathrm{mM}$ cálcio ; (D) representa a comparação da concentração intracelular de cobre $\left(\mu \mathrm{M} \times 22.10^{4} \mathrm{cel}^{-1} \mathrm{x}\right.$ $30 \mathrm{seg}$ ) nas células $B$ do hepatopâncreas ao longo dos 300 segundos de leitura da tomada de cobre incubadas em $20 \mathrm{mM}$ cálcio $(n=4)$. 
$\mathrm{Na}$ figura 15 foi observado que a tomada de cobre foi reduzida na presença de nifedipina, mesmo que em proporções diferentes para cada um dos tipos celulares que compõem o hepatopâncreas. Para as células embriônicas (células E) não houve diferença estatística na comparação dos valores de Vmax, porém obteve-se valor de $p<0,001$ para os valores de $\mathrm{Km}$, onde houve drástica redução de afinidade na presença do inibidor, enquanto que para a população 1 das células R/F houve redução da velocidade de entrada (Vmax) do cobre, assim como para a população 2 das células $R / F$ e das células $B$, com valores de $p<0,001$, 0,01 e 0,001 , respectivamente.

Já em relação aos valores de $\mathrm{Km}$, houve redução dos valores de $\mathrm{Km}$, indicando aumento da afinidade, tanto para a população 1 das células $R / F$, quanto para as células $B$, com $p<0,01$ para ambas, enquanto que a população 2 das células $R / F$ apresentou redução da afinidade do cobre pelas proteínas transmembrana com o aumento dos valores de $\mathrm{Km}$, apresentando diferença estatística de $p<0,05$.

Tabela 13. Valores de $V \max (\mu \mathrm{M})$ e $K m(\mu \mathrm{M})$ para células de hepatopâncreas de Ucides cordatus (média $\pm \mathrm{EP} ; \mathrm{N}=4$ ), onde os asteriscos indicam diferença estatística significativa entre os parâmetros cinéticos apresentados para as células de brânquias (ANOVA, teste T).

\begin{tabular}{clc}
\hline Células & \multicolumn{1}{c}{ Vmax $(\mu \mathrm{M})$} & $\mathrm{Km}(\mu \mathrm{M})$ \\
\hline Controle Células E & $3,1120 \pm 0,1285$ & $0,0050 \pm 0,0030$ \\
\hline Nifedipina Células E & $2,7730 \pm 0,5278$ & $0,1871 \pm 0,1140 * *$ \\
\hline Controle Células R/F(1) & $3,7160 \pm 0,1547$ & $0,0142 \pm 0,0047$ \\
\hline Nifedipina R/F(1) & $2,7620 \pm 0,1302 * * *$ & $0,0044 \pm 0,0034^{* *}$ \\
\hline Controle Células R/F(2) & $3,9530 \pm 0,2084$ & $0,0077 \pm 0,0045$ \\
\hline Nifedipina R/F(2) & $3,5800 \pm 0,0750 * *$ & $0,0248 \pm 0,0034^{*}$ \\
\hline Controle Células B & $2,3400 \pm 0,0845$ & $0,0330 \pm 0,0164$ \\
\hline Nifedipina Células B & $2,0830 \pm 0,0123 * * *$ & $0,0008 \pm 0,0003^{* *}$ \\
\hline
\end{tabular}




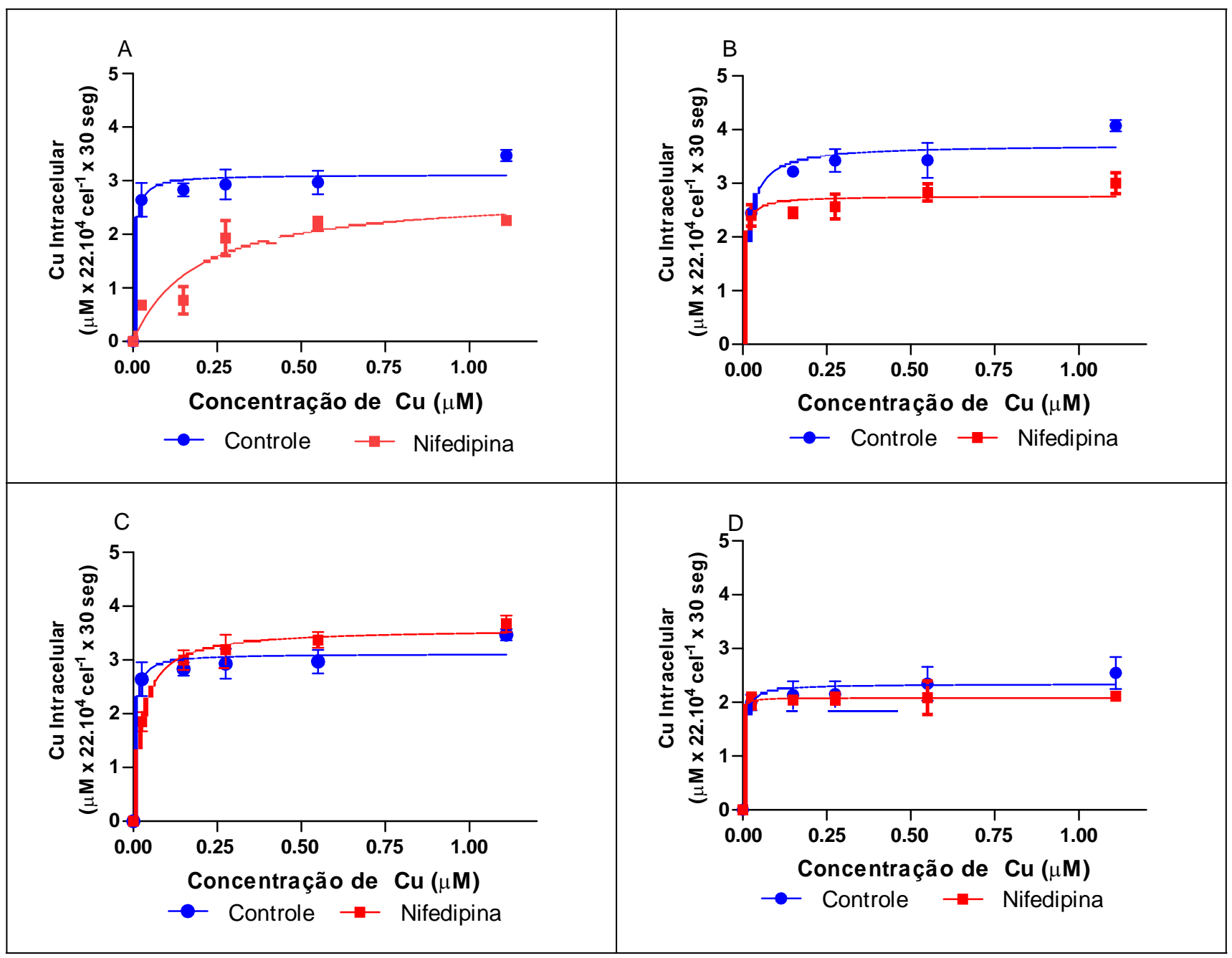

Figura 15. Transporte de cobre nas células epiteliais de hepatopâncreas de Ucides cordatus representando a concentração intracelular de cobre em relação ao aumento crescente de Cu externo na forma de $\mathrm{CuCl}_{2}(0,025 ; 0,150 ; 0,275 ; 0,55 ; 1.110 \mu \mathrm{M})$ onde (A) representa a comparação da concentração intracelular de cobre ( $\left.\mu \mathrm{M} \times 22.10^{4} \mathrm{cel}^{-1} \times 30 \mathrm{seg}\right)$ nas células $\mathrm{E}$ do hepatopâncreas ao longo dos 300 segundos de leitura da tomada de cobre incubadas em $100 \mu \mathrm{M}$ de nifedipina; e (B) representa a comparação da concentração intracelular de cobre $\left(\mu \mathrm{M} \times 22.10^{4} \mathrm{cel}^{-1} \times 30 \mathrm{seg}\right)$ nas células $\mathrm{R} / \mathrm{F}(1)$ do hepatopâncreas ao longo dos 300 segundos de leitura da tomada de cobre incubadas em $100 \mu \mathrm{M}$ de nifedipina; (C) representa a comparação da concentração intracelular de cobre $\left(\mu \mathrm{M} \times 22.10^{4} \mathrm{cel}^{-1} \times 30\right.$ seg) nas células $R / F(2)$ do hepatopâncreas ao longo dos 300 segundos de leitura da tomada de cobre incubadas em $100 \mu \mathrm{M}$ de nifedipina; (D) representa a comparação da concentração intracelular de cobre ( $\left.\mu \mathrm{M} \times 22.10^{4} \mathrm{cel}^{-1} \times 30 \mathrm{seg}\right)$ nas células B do hepatopâncreas ao longo dos 300 segundos de leitura da tomada de cobre incubadas em $100 \mu \mathrm{M}$ de nifedipina $(n=4)$. 
A figura 16 representa a variação da cinética de entrada do cobre nas células de hepatopâncreas na presença de verapamil, já que para as células embriônicas não houve diferença estatística significativa tanto para comparação dos valores de Vmax e Km, embora tenha sido encontrado valores de $p<0,001$ para comparação entre ambas as populações de células $R / F$ e $p<0,05$ para as células $B$ e vale notar que somente para as células $E$ houve aumento da velocidade máxima na presença de verapamil, enquanto que para as demais células houve redução da velocidade máxima de entrada na presença do inibidor e o mesmo é encontrado quando da comparação dos valores de $\mathrm{Km}$, embora somente para os dois tipos celulares $R / F(1)$ e $R / F(2)$ foi obtida diferença estatística com $p<0,05$ e $p<0,001$.

Tabela 14. Valores de $V \max (\mu \mathrm{M})$ e $K m(\mu \mathrm{M})$ para células de hepatopâncreas de Ucides cordatus (média $\pm E P ; N=4$ ), onde os asteriscos indicam diferença estatística significativa entre os parâmetros cinéticos apresentados para as células de brânquias (ANOVA, teste T).

\begin{tabular}{clc}
\hline Células & \multicolumn{1}{c}{ Vmax $(\mu \mathrm{M})$} & $\mathrm{Km}(\boldsymbol{\mu M})$ \\
\hline Controle Células E & $3,1120 \pm 0,1285$ & $0,0050 \pm 0,0030$ \\
\hline Verapamil Células E & $3,2760 \pm 0,2478$ & $0,0083 \pm 0,0066$ \\
\hline Controle Células R/F(1) & $3,7160 \pm 0,1547$ & $0,0142 \pm 0,0047$ \\
Verapamil Células R/F(1) & $2,6890 \pm 0,1460 * * *$ & $0,0052 \pm 0,0040 *$ \\
\hline Controle Células R/F(2) & $3,9530 \pm 0,2084$ & $0,0077 \pm 0,0045$ \\
Verapamil Células R/F(2) & $2,6400 \pm 0,0729 * * *$ & $0,0051 \pm 0,0020 * *$ \\
\hline Controle Células B & $2,3400 \pm 0,0845$ & $0,0330 \pm 0,0164$ \\
\hline Verapamil Células B & $2,1390 \pm 0,1387 *$ & $0,0112 \pm 0,0065$ \\
\hline
\end{tabular}




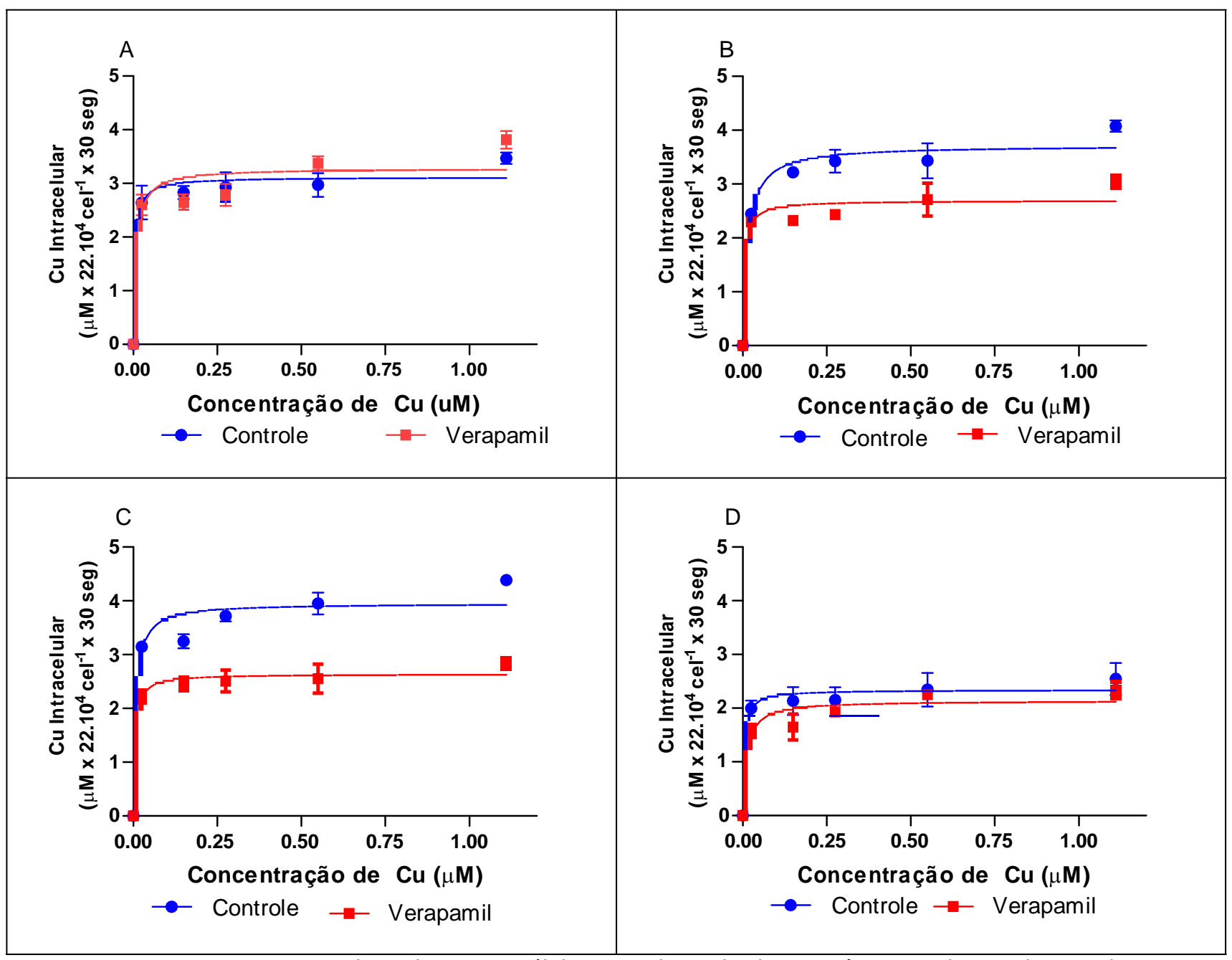

Figura 16. Transporte de cobre nas células epiteliais de hepatopâncreas de Ucides cordatus representando a concentração intracelular de $\mathrm{Cu}$ em relação ao aumento crescente de cobre externo na forma de $\mathrm{CuCl}_{2}(0,025 ; 0,150 ; 0,275 ; 0,55 ; 1.110 \mu \mathrm{M})$ onde (A) representa a comparação da concentração intracelular de cobre ( $\left.\mu \mathrm{M} \times 22.10^{4} \mathrm{cel}^{-1} \times 30 \mathrm{seg}\right)$ nas células $\mathrm{E}$ do hepatopâncreas ao longo dos 300 segundos de leitura da tomada de cobre incubadas em $50 \mu \mathrm{M}$ de verapamil; e (B) representa a comparação da concentração intracelular de cobre $\left(\mu \mathrm{M} \times 22.10^{4} \mathrm{cel}^{-1} \times 30 \mathrm{seg}\right)$ nas células $\mathrm{R} / \mathrm{F}(1)$ do hepatopâncreas ao longo dos 300 segundos de leitura da tomada de cobre incubadas em $50 \mu \mathrm{M}$ de verapamil; (C) representa a comparação da concentração intracelular de cobre $\left(\mu \mathrm{M} \times 22.10^{4} \mathrm{cel}^{-1} \times 30\right.$ seg) nas células $R / F(2)$ do hepatopâncreas ao longo dos 300 segundos de leitura da tomada de cobre incubadas em $50 \mu \mathrm{M}$ de verapamil; (D) representa a comparação da concentração intracelular de cobre $\left(\mu \mathrm{M} \times 22.10^{4} \mathrm{cel}^{-1} \times 30 \mathrm{seg}\right)$ nas células B do hepatopâncreas ao longo dos 300 segundos de leitura da tomada de cobre incubadas em $50 \mu \mathrm{M}$ de verapamil $(n=4)$. 
Na figura 17 são apresentados em valores de RFU (unidade arbitrária de fluorescência) e dessa maneira pode-se observar que houve inibição ainda maior da entrada de cobre nas células do hepatopâncreas e vale notar que as células B apresentaram a maior inibição da entrada de cobre, visto que os valores de Vmax são os menores e maiores, respectivamente. Para os quatro tipos de células do hepatopâncreas foi observada diferença estatística para todos os valores de Vmax com $p<0,05$ para células $E$ e $R / F(2)$ e $p<0,001$ para células $B$ e $R / F(1)$.

Os valores de $\mathrm{Km}$ tanto na presença quanto na ausência de amiloride, foram reduzidos nos quatro tipos celulares incubadas em amiloride e, assim como para os valores de Vmax, obteve-se diferença estatística para todos os grupos comparados com valor $p<0,01$ para células $E, p<0,001$ para as duas populações de células $R / F$ e $p<0,05$ para células $B$ presentes no hepatopâncreas.

Tabela 15. Valores de $V \max (\mu \mathrm{M})$ e $\mathrm{Km}(\mu \mathrm{M})$ para células de hepatopâncreas de Ucides cordatus (média $\pm \mathrm{EP} ; \mathrm{N}=4$ ), onde os asteriscos indicam diferença estatística significativa entre os parâmetros cinéticos apresentados para as células de brânquias (ANOVA, teste T).

\begin{tabular}{ccl}
\hline Células & Vmax $(\mu \mathrm{M})$ & $\mathrm{Km}(\mu \mathrm{M})$ \\
\hline Controle Células E & $4389 \pm 304$ & $0,0068 \pm 0,0056$ \\
\hline Amiloride Células E & $68355 \pm 2667 *$ & $0,0021 \pm 0,0024^{* *}$ \\
\hline Controle Células R/F(1) & $7186 \pm 1258$ & $0,0716 \pm 0,0594$ \\
\hline Amiloride Células R/F(1) & $69620 \pm 1956 * * *$ & $0,0009 \pm 0,0016^{* * *}$ \\
\hline Controle Células R/F(2) & $3256 \pm 80$ & $0,0035 \pm 0,0016$ \\
\hline Amiloride Células R/F(2) & $72235 \pm 1197 *$ & $0,0012 \pm 0,0009 * * *$ \\
\hline Controle Células B & $4865 \pm 660$ & $0,1505 \pm 0,0716$ \\
\hline Amiloride Células B & $67878 \pm 993 * * *$ & $0,0012 \pm 0,0008^{*}$ \\
\hline
\end{tabular}




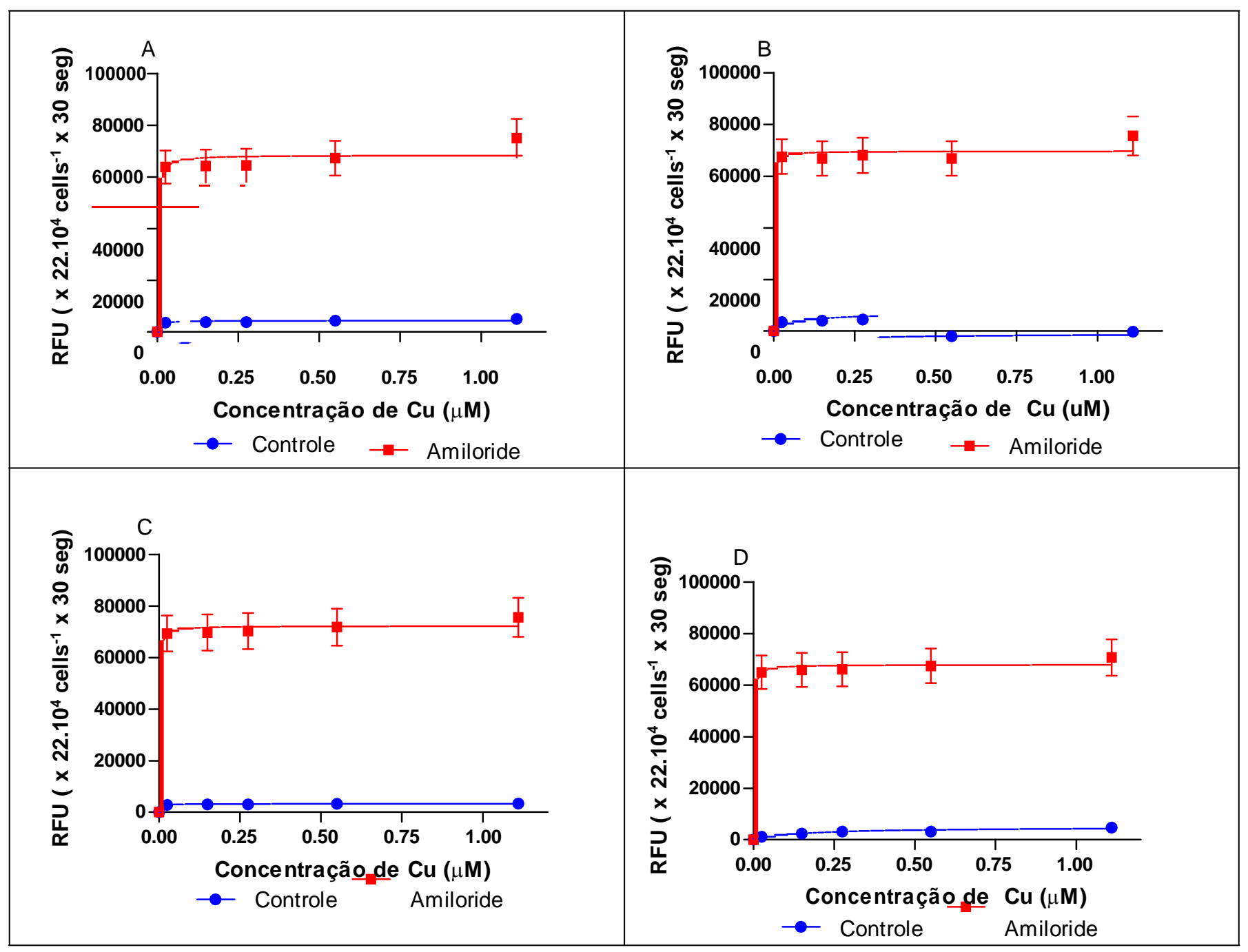

Figura 17. Transporte de cobre nas células epiteliais de hepatopâncreas de Ucides cordatus representando a concentração intracelular de cobre em relação ao aumento crescente de cobre externo na forma de $\mathrm{CuCl}_{2}(0,025 ; 0,150 ; 0,275 ; 0,55 ; 1.110 \mu \mathrm{M})$ onde $(A)$ representa a comparação da concentração intracelular de cobre $\left(\mu \mathrm{M} \times 22.10^{4} \mathrm{cel}^{-1} \times 30 \mathrm{seg}\right)$ nas células $\mathrm{E}$ do hepatopâncreas ao longo dos 300 segundos de leitura da tomada de cobre incubadas em $200 \mu \mathrm{M}$ amiloride; e (B) representa a comparação da concentração intracelular de cobre ( $\mu \mathrm{M} \times 22.10^{4} \mathrm{cel}^{-1} \times 30 \mathrm{seg}$ ) nas células $R / F(1)$ do hepatopâncreas ao longo dos 300 segundos de leitura da tomada de cobre incubadas em $200 \mu \mathrm{M}$ amiloride; (C) representa a comparação da concentração intracelular de cobre $\left(\mu \mathrm{M} \times 22.10^{4} \mathrm{cel}^{-1} \times 30\right.$ seg) nas células $R / F(2)$ do hepatopâncreas ao longo dos 300 segundos de leitura da tomada de cobre incubadas em $200 \mu \mathrm{M}$ amiloride; (D) representa a comparação da concentração intracelular de cobre $\left(\mu \mathrm{M} \times 22.10^{4} \mathrm{cel}^{-1} \times 30 \mathrm{seg}\right)$ nas células B do hepatopâncreas ao longo dos 300 segundos de leitura da tomada de cobre incubadas em $200 \mu \mathrm{M}$ amiloride $(n=4)$. 
A figura 18 apresenta os efeitos causados pela presença de ouabaína nos quatro tipos de células que compõem o hepatopâncreas, e é possível observar que mesmo havendo diferença entre os valores obtidos, a dinâmica da entrada de cobre é a mesma, ou seja, houve redução da Vmax na presença de ouabaína como $p<0,001$ para as células $E$, e as duas populações de células $R / F$, enquanto que para as células $B$ obteve-se $p<0,01$ e assim como para os valores de Vmax, houve redução dos valores de Km na presença de ouabaína com diferença estatística significativa para os quatro tipos celulares, com $p<0,05$ para as células $E$ e $R / F(1), p<0,001$ para as células $R / F(2)$ e $p<0,01$ para células $B$.

Tabela 16. Valores de $\operatorname{Vmax}(\mu \mathrm{M})$ e $\mathrm{Km}(\mu \mathrm{M})$ para células de hepatopâncreas de Ucides cordatus (média $\pm \mathrm{EP} ; \mathrm{N}=4$ ), onde os asteriscos indicam diferença estatística significativa entre os parâmetros cinéticos apresentados para as células de brânquias (ANOVA, teste T).

\begin{tabular}{ccc}
\hline Células & Vmax $(\mu \mathrm{M})$ & $\mathrm{Km}(\mu \mathrm{M})$ \\
\hline Controle Células E & $3,1120 \pm 0,1285$ & $0,0050 \pm 0,0030$ \\
\hline Ouabaína Células E & $2,5830 \pm 0,0160 * * *$ & $0,0015 \pm 0,0003^{*}$ \\
\hline Controle Células R/F(1) & $3,7160 \pm 0,1547$ & $0,0142 \pm 0,0047$ \\
\hline Ouabaína Células R/F(1) & $2,3190 \pm 0,0205 * * *$ & $0,0018 \pm 0,0005^{*}$ \\
\hline Controle Células R/F(2) & $3,9530 \pm 0,2084$ & $0,0077 \pm 0,0045$ \\
\hline Ouabaína Células R/F(2) & $2,1560 \pm 0,0140 * * *$ & $0,0018 \pm 0,0004 * *$ \\
\hline Controle Células B & $2,3400 \pm 0,0845$ & $0,0330 \pm 0,0164$ \\
\hline Ouabaína Células B & $2,1940 \pm 0,0133 * *$ & $0,0008 \pm 0,0003 * *$ \\
\hline
\end{tabular}




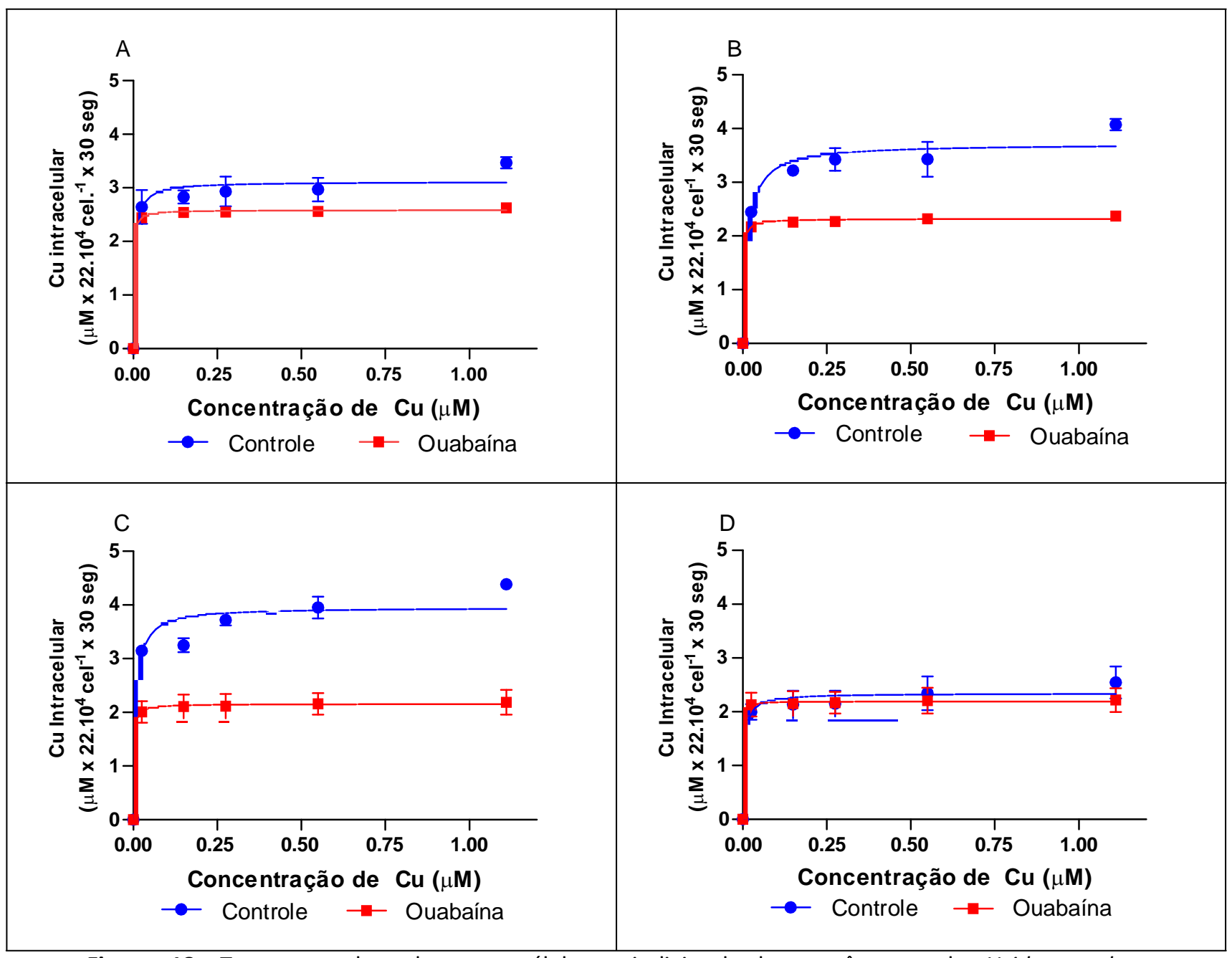

Figura 18. Transporte de cobre nas células epiteliais de hepatopâncreas de Ucides cordatus representando a concentração intracelular de $\mathrm{Cu}$ em relação ao aumento crescente de Cu externo na forma de $\mathrm{CuCl}_{2}(0,025 ; 0,150 ; 0,275 ; 0,55 ; 1.110 \mu \mathrm{M})$ onde $(\mathrm{A})$ representa a comparação da concentração intracelular de cobre ( $\left.\mu \mathrm{M} \times 22.10^{4} \mathrm{cel}^{-1} \times 30 \mathrm{seg}\right)$ nas células $\mathrm{E}$ do hepatopâncreas ao longo dos 300 segundos de leitura da tomada de cobre incubadas em $2 \mathrm{mM}$ ouabaína; e (B) representa a comparação da concentração intracelular de cobre $\left(\mu \mathrm{M} \times 22.10^{4} \mathrm{cel}^{-1} \times 30 \mathrm{seg}\right.$ ) nas células $\mathrm{R} / \mathrm{F}(1)$ do hepatopâncreas ao longo dos 300 segundos de leitura da tomada de cobre incubadas em $2 \mathrm{mM}$ ouabaína; (C) representa a comparação da concentração intracelular de cobre $\left(\mu \mathrm{M} \times 22.10^{4} \mathrm{cel}^{-1} \times 30\right.$ seg) nas células $R / F(2)$ do hepatopâncreas ao longo dos 300 segundos de leitura da tomada de cobre incubadas em $2 \mathrm{mM}$ ouabaína; (D) representa a comparação da concentração intracelular de cobre $(\mu \mathrm{M} x$ $22.10^{4}$ cel $^{-1}$ x $30 \mathrm{seg}$ ) nas células B do hepatopâncreas ao longo dos 300 segundos de leitura da tomada de cobre incubadas em $2 \mathrm{mM}$ ouabaína ( $\mathrm{n}=4)$. 
A figura 19 apresenta os resultados obtidos referente a tomada de cobre na presença ou não de KB-R 7943 e é possível observar que para todos os quatro tipos celulares houve inibição estatisticamente significativa com $p<0,001$ dos valores de Vmax para todas as células, assim como para os valores de $\mathrm{Km}$ houve redução para os quatro tipos de células, com valores de $p<0,01$ para as células $E, p<0,05$ para as células $R / F(1)$ e $p<0,001$ para as células $R / F(2)$ e células $B$.

Tabela 17. Valores de $V \max (\mu \mathrm{M})$ e $K m(\mu \mathrm{M})$ para células de hepatopâncreas de Ucides cordatus (média $\pm \mathrm{EP} ; \mathrm{N}=4$ ), onde os asteriscos indicam diferença estatística significativa entre os parâmetros cinéticos apresentados para as células de brânquias (ANOVA, teste T).

\begin{tabular}{cll}
\hline Células & \multicolumn{1}{c}{ Vmax $(\mu \mathrm{M})$} & $\mathrm{Km}(\mu \mathrm{M})$ \\
\hline Controle Células E & $3,1120 \pm 0,1285$ & $0,0050 \pm 0,0030$ \\
\hline KB-R 7943 Células E & $2,3880 \pm 0,0775 * * *$ & $0,0041 \pm 0,0023^{* *}$ \\
Controle Células R/F(1) & $3,7160 \pm 0,1547$ & $0,0142 \pm 0,0047$ \\
KB-R 7943 Células R/F(1) & $2,4060 \pm 0,2175^{* * *}$ & $0,0088 \pm 0,0081^{*}$ \\
Controle Células R/F(2) & $3,9530 \pm 0,2084$ & $0,0077 \pm 0,0045$ \\
\hline KB-R 7943 Células R/F(2) & $1,8550 \pm 0,0499 * * *$ & $0,0040 \pm 0,0018^{* * *}$ \\
\hline Controle Células B & $2,3400 \pm 0,0845$ & $0,0330 \pm 0,0164$ \\
\hline KB-R 7943 Células B & $1,7870 \pm 0,2116 * * *$ & $0,0071 \pm 0,0098^{* * *}$ \\
\hline
\end{tabular}




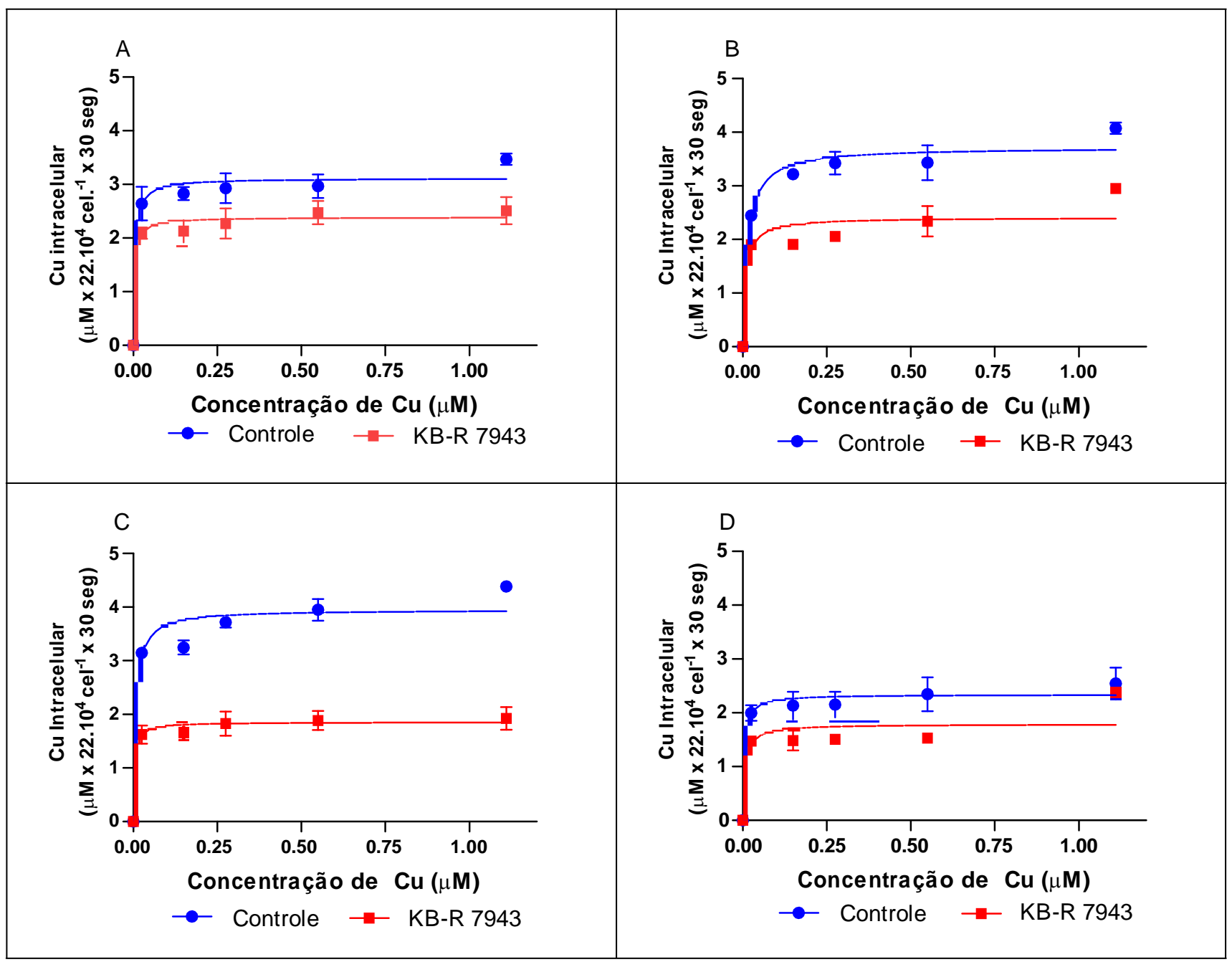

Figura 19. Transporte de cobre nas células epiteliais de hepatopâncreas de Ucides cordatus representando a concentração intracelular de cobre em relação ao aumento crescente de cobre externo na forma de $\mathrm{CuCl}_{2}(0,025 ; 0,150 ; 0,275 ; 0,55 ; 1.110 \mu \mathrm{M})$ onde (A) representa a comparação da concentração intracelular de cobre $\left(\mu \mathrm{M} \times 22.10^{4} \mathrm{cel}^{-1} \times 30 \mathrm{seg}\right)$ nas células $\mathrm{E}$ do hepatopâncreas ao longo dos 300 segundos de leitura da tomada de cobre incubadas em $20 \mu \mathrm{M}$ KB-R 7943; e (B) representa a comparação da concentração intracelular de cobre $\left(\mu \mathrm{M} \times 22.10^{4} \mathrm{cel}^{-1} \times 30 \mathrm{seg}\right.$ ) nas células $R / F(1)$ do hepatopâncreas ao longo dos 300 segundos de leitura da tomada de cobre incubadas em $20 \mu \mathrm{M}$ KB-R 7943; (C) representa a comparação da concentração intracelular de cobre ( $\mu \mathrm{M} \times 22.10^{4}$ cel $^{-1} \times 30 \mathrm{seg}$ ) nas células $R / F(2)$ do hepatopâncreas ao longo dos 300 segundos de leitura da tomada de cobre incubadas em $20 \mu \mathrm{M}$ KB-R 7943; (D) representa a comparação da concentração intracelular de cobre ( $\mu \mathrm{M} \times 22.10^{4} \mathrm{cel}^{-1} \times 30 \mathrm{seg}$ ) nas células B do hepatopâncreas ao longo dos 300 segundos de leitura da tomada de cobre incubadas em $20 \mu \mathrm{M}$ KB-R 7943 (n=4). 
A figura 20 demonstra grande redução da entrada ( $V \max$ ) de cobre na presença de ortovanadato de sódio (Vanadato), principalmente para as duas populações de células R/F, embora as células E e $B$ também tenham apresentado valor de $p<0,001$, caracterizando diferença estatística significativa.

Já para os valores de $\mathrm{Km}$, houve redução do valor deste para as células E incubadas em Vanadato com $p<0,05$, enquanto que para as demais células como as células $R / F(2)$ e $B$ houve aumento dos valores de $\mathrm{Km}$, com $\mathrm{p}<0,001$. Enquanto isso, as células $R / F(1)$ apresentam tendência ao aumento em relação às células controle, visto que não foi obtida diferença significativa.

Tabela 18. Valores de Vmax $(\mu \mathrm{M})$ e $\mathrm{Km}(\mu \mathrm{M})$ para células de hepatopâncreas de Ucides cordatus (média $\pm \mathrm{EP} ; \mathrm{N}=4$ ), onde os asteriscos indicam diferença estatística significativa entre os parâmetros cinéticos apresentados para as células de brânquias (ANOVA, teste T).

\begin{tabular}{clc}
\hline Células & \multicolumn{1}{c}{ Vmax $(\mu \mathrm{M})$} & $\mathrm{Km}(\mu \mathrm{M})$ \\
\hline Controle Células E & $3,1120 \pm 0,1285$ & $0,0050 \pm 0,0030$ \\
\hline Vanadato Células E & $1,4470 \pm 0,0494 * * *$ & $0,0030 \pm 0,0022 *$ \\
\hline Controle Células R/F(1) & $3,7160 \pm 0,1547$ & $0,0142 \pm 0,0047$ \\
Vanadato Células R/F(1) & $0,4428 \pm 0,0363 * * *$ & $0,0239 \pm 0,0130$ \\
\hline Controle Células R/F(2) & $3,9530 \pm 0,2084$ & $0,0077 \pm 0,0045$ \\
\hline Vanadato Células R/F(2) & $0,2819 \pm 0,0303 * * *$ & $0,0107 \pm 0,0106 * *$ \\
\hline Controle Células B & $2,3400 \pm 0,0845$ & $0,0330 \pm 0,0164$ \\
\hline Vanadato Células B & $1,0050 \pm 0,2079 * * *$ & $0,1272 \pm 0,0990 * * *$ \\
\hline
\end{tabular}




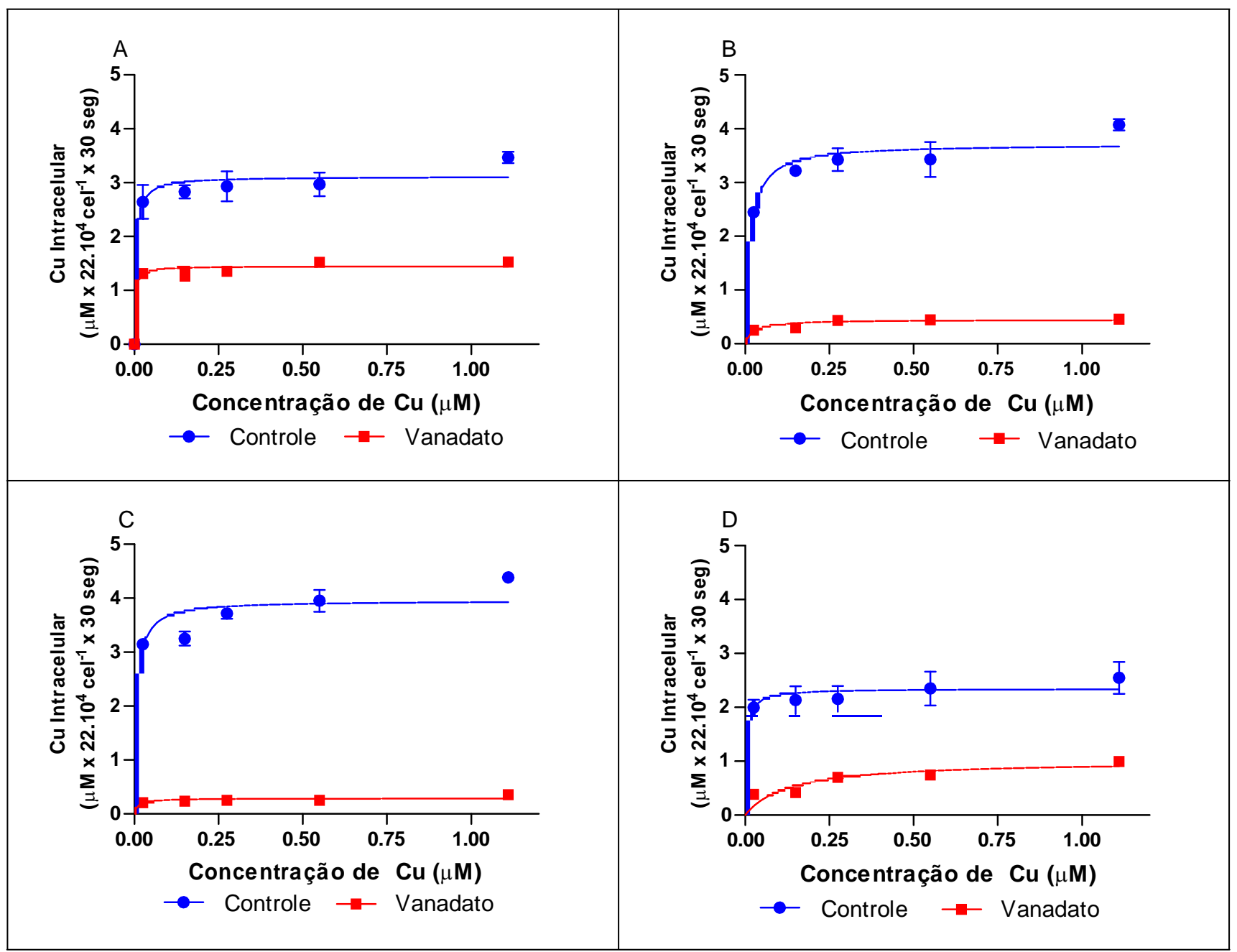

Figura 20. Transporte de cobre nas células epiteliais de hepatopâncreas de Ucides cordatus representando a concentração intracelular de cobre em relação ao aumento crescente de cobre externo na forma de $\mathrm{CuCl}_{2}(0,025 ; 0,150 ; 0,275 ; 0,55 ; 1.110 \mu \mathrm{M})$ onde (A) representa a comparação da concentração intracelular de cobre ( $\left.\mu \mathrm{M} \times 22.10^{4} \mathrm{cel}^{-1} \times 30 \mathrm{seg}\right)$ nas células $\mathrm{E}$ do hepatopâncreas ao longo dos 300 segundos de leitura da tomada de cobre incubadas em $20 \mathrm{mM}$ vanadato; e (B) representa a comparação da concentração intracelular de cobre $\left(\mu \mathrm{M} \times 22.10^{4} \mathrm{cel}^{-1} \times 30 \mathrm{seg}\right)$ nas células $\mathrm{R} / \mathrm{F}(1)$ do hepatopâncreas ao longo dos 300 segundos de leitura da tomada de cobre incubadas em $20 \mathrm{mM}$ vanadato; (C) representa a comparação da concentração intracelular de cobre $\left(\mu \mathrm{M} \times 22.10^{4} \mathrm{cel}^{-1} \times 30\right.$ seg) nas células $R / F(2)$ do hepatopâncreas ao longo dos 300 segundos de leitura da tomada de cobre incubadas em $20 \mathrm{mM}$ vanadato; (D) representa a comparação da concentração intracelular de cobre $\left(\mu \mathrm{M} \times 22.10^{4} \mathrm{cel}^{-1} \times 30 \mathrm{seg}\right)$ nas células $\mathrm{B}$ do hepatopâncreas ao longo dos 300 segundos de leitura da tomada de cobre incubadas em $20 \mathrm{mM}$ vanadato $(n=4)$. 


\section{DISCUSSAO}

Muitos contaminantes ambientais não somente entram através das brânquias, mas também exercem efeitos tóxicos primários no epitélio branquial, devido à interferência junto a um ou mais processos fisiológicos essenciais dos animais aquáticos (WOOD, 1992). A relativa importância dessas rotas tem sido foco de muitos estudos, tanto em peixes marinhos quanto em peixes de água doce (BURY e col., 2003), assim como em outros animais aquáticos que também acumulam metais essenciais ou não essenciais. Estes metais, por sua vez, podem apresentar potencial para causar efeitos tóxicos, e estudos demonstram haver uma enorme variabilidade das concentrações de metais acumuladas nos tecidos de invertebrados (RAINBOW, 2007).

O epitélio é basicamente uma camada única de células e a habilidade adaptativa para se "recuperar" dos danos causados pelos metais é restrita (YANG e col., 2007). As células epiteliais das brânquias, hepatopâncreas, glândula antenal e tegumento, em crustáceos, controlam os movimentos de cátions e ânions entre hemolinfa e meio ambiente, e, assim, atuam em atividades biológicas como regulação iônica e osmótica, acidificação gástrica, ecdise e destoxificação de metais (MARTINEZ e col., 1999).

Quando o metal é tomado e penetra o crustáceo, quer seja através de superfícies externas permeáveis, como as brânquias, ou através do epitélio do hepatopâncreas, estará inicialmente disponível para ser metabolizado, apresentando, portanto, potencial para se ligar às moléculas receptoras das células, após o transporte via hemolinfa (RAINBOW, 2007). A hemolinfa contém diversas proteínas que participam da ligação com o metal e, subseqüentemente, transportam-no para os órgãos para utilização, estoque e/ou excreção. Tal dinâmica intracelular de captação do metal é parte do processo de regulação e destoxificação, o qual pode ser influenciado por respostas fisiológicas ao ambiente (CHOWDHURY e col., 2003).

Devido à presença de mecanismos regulatórios nas células epiteliais das brânquias e do trato gastrinstestinal para o controle da entrada de metais provenientes do meio-ambiente e da dieta em animais aquáticos, sugere-se que os transportadores de metais sejam conservados ao longo do processo evolutivo desses animais, claramente observados através de estudos realizados em diferentes filos, em resposta a esse "desafio" fisiológico comum. 
Conseqüentemente, o modelo aceito até o presente momento se baseia em um mecanismo comum para a regulação epitelial de uma grande variedade de metais em animais presentes em ambientes diversos, desde marinho até terrestre, passando pelos ambientes dulcícola e estuarino.

BRIX \& DEFOREST (2000) formularam com base em fatores de bioacumulação, a hipótese de que o biota aquático pode regular sua concentração interna de metais essenciais de três formas: (i)regulação ativa, (ii) acúmulo, ou (iii) a combinação de ambos os mecanismos (BOSSUYT \& JANSSEN, 2005), e uma das possibilidades de que isso ocorra é que vacúolos subcuticulares fornecem um caminho para o movimento da água, diminuindo sua entrada na célula e possivelmente, também, a taxa de entrada de cobre nas células. Tal vacuolização do epitélio poderá provocar alterações dos processos fisiológicos nas brânquias, em conseqüência do aumento da distância de difusão para os íons e gases respiratórios (LAWSON e col., 1995).

Os estudos sobre transporte de cobre, realizados no passado, utilizavam animais inteiros e focavam principalmente os fatores que influenciavam a absorção intestinal. Por isso, pouca atenção foi dada aos movimentos que ocorrem dentro da célula, onde aminoácidos, ATP e proteínas solúveis são capazes de auxiliar o movimento do cobre dentro da célula, ou detê-lo (HARRIS \& SANTOS, 2000). A literatura tem reportado efeitos adversos do cobre nos transportes iônico passivo e ativo dos animais como um todo. Portanto, o cobre tem sido reconhecido como um agente tóxico osmorregulatório, que induz distúrbios ionorregulatórios em organismos aquáticos (PAGANINI \& BIANCHINI, 2009).

\section{ATP}

Os estudos realizados até o presente mostram que o cobre se move entre organelas e através da membrana, principalmente associado a proteínas que buscam atingir alvos pequenos e em conjunto com mecanismos governados por ATP. Além disso, o transporte celular de cobre tem seus componentes muito bem conservados ao longo da evolução (HARRIS \& SANTOS, 2000).

Os transportadores de cobre requerem uma redutase na membrana, a qual utiliza $\mathrm{NADH}$ como doador de elétrons para a redução de $\mathrm{Cu}^{2+}$ para $\mathrm{Cu}^{+}$, concomitante com a penetração na célula (HARRIS \& SANTOS, 2000). O metal então é tomado como $\mathrm{Cu}^{+}$e, uma vez internalizado, parte deste cobre é quelado por excesso de glutationa intracelular (GSH), inibindo a formação de radicais livres do $\mathrm{Cu}^{+}$e $\mathrm{H}_{2} \mathrm{O}_{2}$ (BROUWER e col., 2002). Uma vez dentro das brânquias, o cobre se liga a proteínas de membrana (WEBB, 1979; EVTUSHENKO e col., 
1986) e a tomada de metais junto às brânquias dos crustáceos e hemolinfa ocorre então passivamente de acordo com o gradiente de concentração com a ajuda de proteínas carreadoras e/ou através de transporte ativo (SIMKISS \& TAYLOR, 1989; HEBEL e col., 1997).

Os lisossomos são considerados como o principal local de compartimentalização de metais nas células dos invertebrados marinhos (STERLEIB \& GOLDFISCHER, 1976). Os metais se acumulam dentro dos lisossomos em altas concentrações e sob formas não tóxicas, como, por exemplo, ligados à metalotioneína (VIARENGO, 1985; HEBEL e col., 1997; HAVELAAR e col. 1998). Estes autores citam a presença de um sistema de transporte de metal na membrana do lisossomo estimulada por hidrólise de ATP. Geralmente, metais essenciais, como cobre e zinco, tendem a serem regulados ativamente por crustáceos decápodas, algas e peixes (BOSSUYT \& JANSSEN, 2005).

Os resultados obtidos por CHAVEZ-CROOKER e col, (2003 a;b), fornecem pela primeira vez, evidências da presença de um transporte ativo, mediado por carreadores para o íon cobre, na membrana lisossômica do epitélio branquial do hepatopâncreas de lagosta Homarus americanus. Tal transporte aparenta ser parte do mecanismo de sequestro para compartimentalização desse metal potencialmente tóxico (CHAVEZ-CROOKER e col., 2003a;b).

CHAVEZ-CROOKER (2003a;b) usou um marcador específico para cobre, Phen Green, para caracterizar os mecanismos responsáveis pela tomada de cobre por vesículas da membrana lisossômica (LMV) de células de hepatopâncreas de lagostas. Este estudo sugere que a tomada de cobre por essa organela ocorre pela combinação da ação da Cu-ATPase e por difusão facilitada pelo antiporte de $\mathrm{Cu}^{2+} / \mathrm{H}^{+}$na mesma membrana (MANDAL e col., 2006). CHAVEZ-CROOKER e col. (2001; 2002; 2003a;b) e MANDAL e col. (2006) utilizaram a combinação de marcador fluorescente específico de cobre, Phen Green, e o isótopo de zinco $\left({ }^{65} \mathrm{Zn}^{2+}\right)$ e sugeriram que tanto cobre quanto zinco são transportados pelos lisossomos do hepatopâncreas, na dependência de ATP, respectivamente.

DIJKSTRA e col.(1996) mostraram a presença de um sistema de transporte de cobre dependente de ATP em seres humanos, mais precisamente na membrana plasmática do fígado. Estas ATPases mediam a translocação do cobre através da membrana celular por meio de um ciclo catalítico, no qual a energia derivada da hidrólise de ATP direciona os cátions através da membrana (FONTAINE \& MERCER, 2007).

As ATPases transportadoras de cobre são parentes de outros transportadores de cátions, tais como $\mathrm{Na} / \mathrm{K}, \mathrm{H} / \mathrm{K}$ e Ca-ATPases (FONTAINE \& MERCER, 2007), sendo altamente 
conservadas em diversos organismos ao longo da evolução, passando por Drosophila, ratos, carneiros e seres humanos (FATEMI \& SARKAR, 2002).

\section{Sódio}

O mecanismo de toxicidade do cobre em trutas arco-íris (Salmo gairdneri) consiste numa redução da afinidade de transportadores de sódio (inibição competitiva) e também numa redução da capacidade de tomada de sódio (inibição não competitiva) (MATSUO e col., 2005). O sódio claramente inibe a tomada de cobre e o inverso é verdadeiro, como citado anteriormente. O efeito do cobre na tomada de sódio é associado à inibição da $\mathrm{Na}^{+} / \mathrm{K}^{+}$-ATPase presente na membrana basolateral (GROSELL \& WOOD, 2002).

Uma ampla variedade de células epiteliais de vertebrados possui em suas membranas plasmáticas proteínas trocadoras $\mathrm{Na} / \mathrm{H}$, as quais catalisam a de tomada de sódio extracelular associada à extrusão de prótons citoplasmáticos (GRISTEIN, 1985; AHEARN e col., 1994). Este mecanismo antiporte (quando dois substratos se movem em sentidos opostos como por exemplo trocador $\mathrm{Na} / \mathrm{H}$ ) inclui a regulação do $\mathrm{pH}$ intracelular, do volume celular e do transporte transcelular de sódio e bicarbonato, nas mais variadas funções biológicas ( AHEARN e col., 1994).

O trocador sódio/próton $\left(\mathrm{Na}^{+} / \mathrm{H}^{+}\right)$na membrana apical de hepatopâncreas é sensível à amiloride e é eletrogênico, possuindo estequiometria de $2 \mathrm{Na}^{+} / 1 \mathrm{H}^{+}$. Tais propriedades fisiológicas do trocador $2 \mathrm{Na}^{+} / 1 \mathrm{H}^{+}$também se encontram presentes nas glândulas antenais (AHEARN \& FRANCO, 1990) e no ceco pilórico de estrela-do-mar (AHEARN \& FRANCO, 1991). AHEARN \& FRANCO (1990; 1993) e AHEARN e col. (1999) demonstraram que o cátion divalente cálcio é o substrato transportado por esse processo de carreamento, no lugar de dois íons monovalentes de sódio, e é conhecido como trocador $\mathrm{Ca}^{+} / \mathrm{H}^{+}$.

Trocadores $\mathrm{Na}^{+} / \mathrm{H}^{+}, \mathrm{Na}^{+} / 2 \mathrm{Cl}^{-}$e $\mathrm{K}^{+} / 2 \mathrm{Cl}^{-}$estão envolvidos no movimento de íons sódio do meio externo para o citoplasma em animais estuarinos. Uma V-ATPase e um canal de sódio também aparentam estar envolvidos na tomada osmorregulatória de íons no epitélio branquial de espécies de caranguejos tolerantes à água doce (TOWLE \& WEIHRAUCH, 2001; ONKEN e col., 2003; MASUI e col., 2005).

Em membrana de borda em escova de vesículas de tecidos de invertebrados, cátions divalentes, como cálcio, ou metais como zinco ou cádmio, são capazes de tomar o lugar do 
sódio como um ligante externo e como um trocador de íons hidrogênio no lado trans da membrana (MANDAL e col., 2003). É possível que o cobre entre para a hemolinfa via transportadores de sódio no trato digestório. Cátions de ocorrência natural, incluindo sódio, competem com metais, como o cobre, por sítios de ligação no organismo e tal competição pode levar à redução da tomada desse metal (SABATINI e col., 2009).

Amiloride é um agente competitivo do influxo de sódio, inibindo a entrada de cátions divalentes (AHEARN e col., 1994), assim como também é um inibidor bem conhecido do antiporte $1 \mathrm{Na}^{+} / \mathrm{H}^{+}$eletroneutro (MANDAL e col., 2003).

Um sistema de transporte eletrogênico $2 \mathrm{Na}^{+} / 1 \mathrm{H}^{+}$similar foi descrito para brânquias do caranguejo Carcinus maenas, também sensível à amiloride. Um modelo de transporte iônico pelas brânquias de crustáceos prevê uma localização apical desse trocador $\mathrm{Na}^{+} / \mathrm{H}^{+}$(face para ambiente externo), junto aos antiporte $\mathrm{Cl}^{-} / \mathrm{HCO}_{3}{ }^{-}$e $\mathrm{Ca}^{2+} / 1 \mathrm{H}^{+}$(AHEARN e col., 1999).

Em lagostas Homarus americanus, o trocador $\mathrm{Na}^{+} / \mathrm{H}^{+}$foi observado na membrana basolateral, sendo este trocador eletroneutro, com estequiometria $1 \mathrm{Na}^{+} / 1 \mathrm{H}^{+}$, e insensível a cátions divalentes (AHEARN e col., 1999). Além disso, esse trocador é alostericamente regulado pela concentração de hidrogênio intracelular, de modo que o antiporte pode responder imediatamente e de forma autônoma a uma acidificação do citosol (ARONSON e col., 1982). Este transportador pode também ser ativado pela fosforilação da proteína quinase (GRISTEIN e col., 1985; AHEARN e col., 1999).

Com a ocupação de locais/sítios de ligação externa desses transportadores por cátions divalentes, a troca continua sendo eletrogênica, desde que o excesso de carga positiva seja transferido para a vesícula anterior. Uma análise detalhada das propriedades de influxo de cálcio no epitélio do hepatopâncreas de crustáceos indica que este cátion divalente é capaz de atravessar a membrana luminal das células do epitélio gastrointestinal, ou renal, pelo "caminho" proporcionado por três proteínas: (i) sensível à amiloride, eletrogênica, $2 \mathrm{Na}^{+} / 1 \mathrm{H}^{+}$ antiporter; $\left(1 \mathrm{Ca}^{2+}\right.$ reloca $\left.2 \mathrm{Na}^{+}\right)$; (ii) insensível à amiloride, eletroneutro, $1 \mathrm{Ca}^{2+} / 2 \mathrm{Na}^{+}$antiporte; (iii) canal de cálcio sensível à verapamil (MANDAL e col., 2003).

Amiloride é conhecido por inibir canais de cálcio e trocador $\mathrm{Na} / \mathrm{H}$. Os resultados apresentados neste capítulo mostram ampla redução da concentração de cobre intracelular (em unidade arbitrária de fluorescência - RFU), ao contrário do que foi observado para o transporte de cobre em células de hepatopâncreas de lagosta Homarus americanus (CHAVEZCROOKER e col., 2001). Por isso, resultados obtidos a partir da utilização de bloqueadores de 
trocadores $1 \mathrm{Ca}^{+} / 1 \mathrm{Na}^{+}$, assim como o inibidor de $\mathrm{Na}^{+} / \mathrm{K}^{+}$-ATPase (ouabaína), sugerem que o cobre tomado pelas células de Ucides cordatus é fortemente dependente da concentração de sódio, além de ser também dependente de cálcio (PAGANINI e col., 2008). A concentração final de cobre menor que a inicial pode indicar a ocorrência de seqüestro de cobre por lipídios e/ou proteínas da membrana, tanto quanto por componentes da mistura de incubação (SHINGLES e col., 2004).

Existem diversas enzimas responsáveis pelo transporte iônico nas brânquias e hepatopâncreas de crustáceos, incluindo $\mathrm{Na}^{+} / \mathrm{K}^{+}$ATPase, $\mathrm{H}^{+}$-ATPase, anidrase carbônica, trocador $\mathrm{Cl}^{-} / \mathrm{HCO}_{3}{ }^{-}$e trocador $\mathrm{Na}^{+} / \mathrm{H}^{+}$(TSAI \& LIN,2007). A H $\mathrm{H}^{+}$-ATPase tem sido descrita como a responsável pelo balanço ácido-base e excreção de nitrogênio. Trata-se de uma proteína altamente conservada em eucariontes, tanto em plantas como em animais (LIN \& RANDALL, 1993; TSAI \& LIN,2007). Vários trabalhos sugerem que a $\mathrm{H}^{+-}$ATPase (ATPase dependente de hidrogênio) esteja envolvida nos processos osmorregulatórios quando localizada na membrana apical das células de caranguejos (TSAI \& LIN,2007), e também tem sido reportada como presente em vesículas citoplasmáticas (LIN \& RANDALL, 1993).

A bafilomicina é um antibiótico de ocorrência natural, que funciona como um inibidor muito especifico das ATPases de translocação de prótons vacuolares $\left(\mathrm{H}^{+}\right.$ou V-ATPase) (FENWICK e col., 1999), reduzindo significativamente o influxo de cobre pelas vesículas das membranas de lisossomos (LMV) na presença de ATP, presumidamente pela redução do gradiente de prótons para acúmulo desse metal (MANDAL e col., 2006).

Enquanto em Eriocheir sinensis, a $\mathrm{H}^{+}$-ATPase está localizada na membrana apical do epitélio branquial (ONKEN \& PUTZENLECHNER, 1995), em Carcinus maenas esta ATPase foi encontrada predominantemente no citoplasma, provavelmente associada a vesículas (WEIHRAUCH e col., 2004). Segundo FREIRE e col. (2008), em Eriocheir sinensis, a V( $\left.\mathrm{H}^{+}\right)-$ ATPase, inibida por bafilomicina, encontra-se localizada exclusivamente nas células pilares (CHAVEZ-CROOKER e col., 2003 a;b) das brânquias.

É evidente que a tomada de sódio é extremamente sensível à bafilomicina. Na presença desta droga, esta V-ATPase é inibida e a concentração de hidrogênio aumenta, levando a uma redução da força motriz para entrada de sódio, com consequente redução da entrada de sódio nas células (FENWICK e col., 1999).

Passadas quatro décadas, a $\mathrm{Na}^{+} / \mathrm{K}^{+}$-ATPase continua sendo reconhecida como uma proteína de transporte na membrana plasmática das células animais, a qual "expulsa" sódio 
para o citosol e simultaneamente importa potássio para dentro da célula, dependente da hidrólise de ATP (LUCU \& TOWLE, 2003).

A inibição do influxo de sódio em peixes de água doce é típico da resposta à presença de cobre na água. Acredita-se que tal inibição ocorra como resultado da interação entre o cobre e os grupos sulfidril presentes na $\mathrm{Na}^{+} / \mathrm{K}^{+}-\mathrm{ATPase}$ basolateral, bloqueando, consequentemente, a entrada apical de sódio (MATSUO e col., 2005).

A mesma tendência também é observada nas células incubadas em K-BR 7943, um inibidor do trocador $\mathrm{Na} / \mathrm{Ca}$ com função de captar cálcio para o meio intracelular. O mecanismo geral descrito aqui envolve, portanto, uma redução da tomada de cobre decorrente do uso de diferentes inibidores que bloqueiam o influxo de cálcio. Os resultados obtidos no presente trabalho sugerem a presença de um trocador $\mathrm{Cu} / \mathrm{Ca}$, também sugerido por CHAVEZ-CROOKER e col. (2001), por meio do qual o cálcio intracelular pode ser trocado pelo cobre extracelular, ou ativar o influxo de cobre.

\section{Cálcio}

A tomada de qualquer metal no nível da membrana celular é governada por um transportador específico, por canais de proteínas, difusão passiva de metais lipossolúveis ou também por endocitose (ALCORLO e col., 2006). O estudo feito por HOGSTRAND e col. (1998) foi o primeiro a explorar a cinética de Michaelis-Menten para o influxo de cálcio e zinco durante exposição de peixes a elevados níveis de zinco na água. A exposição prévia de zinco provocou redução na afinidade do sistema de transporte de cálcio e a aclimatação fisiológica ao zinco é associada à diminuição da tomada do mesmo (HOGSTRAND e col., 1998). MCDONALD \& WOOD (1993) propuseram que o ajuste à exposição ao metal decorre de um processo com duas etapas, envolvendo, no início, um dano no epitélio branquial, seguido por um período de reparo do tecido, durante o qual mecanismos responsáveis pelo ajuste são expressos (McDONALD \& WOOD, 1993). O zinco se encontra disponível na água como um cátion divalente livre, $\mathrm{Zn}^{2+}$, e, em parte, possui uma rota de tomada muito parecida com a do cálcio em brânquias de peixes de água doce. Assim, o aumento de zinco altera a tomada de cálcio através das brânquias, levando a uma hipocalcemia, a qual pode levar à morte do animal em poucos dias, dependendo da concentração (NIYOGI \& WOOD, 2006). Portanto, as brânquias representem o principal sítio para a entrada de muitos dos agentes contaminadores presentes na água (WOOD, 1992; SÁ e col., 2009). Uma resposta similar foi descrita para o 
zinco (tomado através das brânquias de trutas) em ambiente com concentrações crescentes de cálcio; os dois metais apresentam dinâmicas de tomada muito similares (GROSELL \& WOOD, 2002; SÁ e col., 2009).

Recentemente, como parte do estudo da caracterização dos mecanismos de transporte de cálcio através da membrana do lúmen do hepatopâncreas de lagostas, os metais zinco e cobre foram encontrados como sendo competidores e inibidores da tomada de cálcio, além de serem capazes de estimular o efluxo intracelular de cálcio, através de processos carreadores na membrana apical. (AHEARN e col., 1994; ZHUANG \& AHEARN, 1996; AHEARN e col., 1999; MARTINEZ e col., 1999).

Os efeitos sobre os processos osmorregulatórios e respiratórios induzidos por elevadas concentrações de metais pesados já são conhecidos nos crustáceos (LAWSON e col., 1995). Muitas investigações têm demonstrado que concentrações elevadas de cálcio na água resultam em uma proteção contra a toxidez causada pelo zinco ou outros metais, com inibição ou redução da entrada de metais como cádmio e zinco, em peixes (SPRY \& WOOD, 1989; WOOD, 1992) e que o zinco compete com a tomada de cálcio (BARRON \& ALBEKE, 2000; BURY e col., 2003; NIYOGI \& WOOD, 2006). As relações entre as homeostases de cálcio e zinco são também aparentes na fase de tomada destes metais na porção apical das células branquiais.

CHAVEZ-CROOKER e col. (2001) sugeriram que a tomada de cobre pelas células epiteliais do hepatopâncreas de lagostas Homarus americanus ocorre pela combinação de processos de transporte dependentes e independentes de cálcio. O cálcio, aparentemente, afeta tanto a constante cinética $(\mathrm{Km})$ como o Vmax, no transporte de cobre, sugerindo que a ligação do metal e a taxa máxima de transporte através da membrana são influenciadas pelo cálcio. Esses mesmos autores também sugerem que cobre e zinco podem utilizar os mesmos sistemas de transporte dependentes de cálcio, mediados por carreadores, nos quatro tipos celulares do epitélio de hepatopâncreas (CHAVEZ-CROOKER e col., 2001). Experimentos realizados com células epiteliais isoladas de hepatopâncreas revelaram nestas células a presença de canais sensíveis a verapamil e este bloqueador de canais de cálcio inibe de modo significativo a tomada de cobre ou zinco pelas células de hepatopâncreas (CHAVEZ-CROOKER e col., 2001).

Os peixes de água doce aclimatados em água rica em zinco só se aclimataram devido a uma co-regulação, nas brânquias, das propriedades cinéticas dos transportadores $\mathrm{Ca}^{2+} / \mathrm{Zn}^{2+}$. O $\mathrm{Km}$ (inverso da afinidade) da tomada de cálcio nas brânquias diminui substancialmente, enquanto o Vmax (máxima tomada) altera muito pouco (NIYOGI \& WOOD, 2006). O mesmo foi 
observado, no presente estudo, em células de hepatopâncreas de Ucides cordatus incubadas em cálcio. (HOGSTRAND e col., 1998).

Se as entradas de zinco e cálcio, na porção apical, ocorrerem por meio do mesmo mecanismo de transporte supracitado e se o aumento do $\mathrm{Km}$ para cálcio resultar na redução da afinidade pelo zinco, então, alterações no Km do influxo de cálcio e zinco deveriam ocorrer de maneira coordenada (HOGSTRAND e col., 1994; 1998).

A exposição prévia ao zinco induz a redução da afinidade do sistema de transporte de cálcio e a aclimatação fisiológica ao zinco é associada à diminuição da tomada de zinco (HOGSTRAND e col., 1998). A interação competitiva entre zinco e cálcio (e consequentemente cobre e cálcio) sugere que a tomada de cobre pelas brânquias também ocorre via células de cloreto. (HOGSTRAND e col., 1994).

Hoje, existem evidências de que zinco, cádmio e cobre entram nas brânquias de peixes de água doce por meio de um canal de cálcio situado na membrana apical. Na presença de aumento das concentrações de cálcio no ambiente, a afinidade do sistema de transporte para zinco, cádmio e cobalto diminuem (afinidade constante, aumento do $\mathrm{Km}$ ), ilustrando a competição existente entre cálcio e íons de metais supracitados (BURY \& WOOD, 1999).

O influxo de cálcio pode ocorrer de modo passivo através das brânquias, por uma via paracelular a partir da presença de altas concentrações de cálcio no meio externo (2-10 mM) e de baixas concentrações no meio interno (20 $\mu \mathrm{M}$ ) (PEDERSEN \& BJERREGAARD, 1995). Já o cálcio intracelular é transportado através da membrana basolateral pela $\mathrm{Ca}^{2+}$ - ATPase e a entrada de metais no meio intracelular se dá, provavelmente, com a ligação do metal à proteína metalotioneína no citosol (PEDERSEN \& BJERREGAARD, 1995). Além disso, acredita-se que o cálcio penetre o epitélio branquial através de transportadores insensíveis à voltagem (canais iônicos ou por difusão facilitada), localizados na membrana apical (PEDERSEN \& BJERREGAARD, 1995).

No estudo de WHEATLY e col. (1999), o Vmax foi maior para as brânquias e glândula antenal de lagostins do que para o hepatopâncreas, sugerindo que os epitélios branquial e renal poderiam atuar, ao menos potencialmente, com maior ênfase que a glândula digestiva na homeostase de cálcio. Para que isso de fato ocorresse, seria necessário supor que as proteínas transportadoras de cálcio poderiam contribuir igualmente para o total de proteína existente em cada tecido, já que as taxas de tomada são expressas em mg total de proteína. Os dados de HOGSTRAND e col. (1995) corroboram tal suposição ao demonstrar que grandes 
alterações do Km, pequenas mudanças do Vmax e redução da afinidade dos carreadores para cálcio podem servir para reduzir o influxo de zinco, e possivelmente o de cobre também.

Alguns estudos demonstraram que os quatro tipos celulares de hepatopâncreas exibem taxas qualitativamente similares, mas quantitativamente variadas de acúmulo de cobre, e, uma vez dentro da célula, as mitocôndrias transportam íons cobre para o seu interior por um caminho na membrana associado ao sistema de transporte de cálcio e o metal toma lugar do cálcio durante o evento de translocação (CHAVEZ-CROOKER e col., 2003 a;b). CHAVEZCROOKER e col. (2001) sugeriram que os quatro tipos celulares aparentam possuir processos de transporte de cobre saturável e dependente de cálcio.

Os resultados obtidos por CHAVEZ-CROOKER e col (2001) sugerem que a tomada de cobre pelas células epiteliais do hepatopâncreas ocorre por uma combinação de processos dependentes e independentes do cálcio De acordo com CHAVEZ-CROOKER e col., (2001), a tomada de cobre independente de cálcio foi mínima nas células $E$ e $R$, enquanto uma transferência significativa do metal ocorreu na ausência de cálcio nas células $F$ e B. Após terem feito tais observações, CHAVEZ-CROOKER e col. (2003a;b) demonstraram que a tomada de cobre por lisossomos de hepatopâncreas é mediada por carreadores dependentes da concentração de cálcio extracelular e estimulados pelo cálcio citosólico, sendo que a tomada de cobre pode também ocorrer independentemente da presença de cálcio (CHAVEZ-CROOKER e col., 2003).

Verapamil e nifedipina são bloqueadores de canais de cálcio dependentes de voltagem, diferentes entre si (PERRY \& FLICK, 1988). O verapamil inibe o canal de cálcio e atua junto ao canal sensível ao potencial de membrana (AHEARN e col., 1994) e a nifedipina inibe canais de cálcio do tipo L (PERRY \& FLICK, 1988).

CHAVEZ-CROOKER e col. (2003a;b) sugeriram que verapamil e nifedipina provocam uma inibição significativa da tomada de cobre por todas as quatro células constituintes do hepatopâncreas e tal efeito inibitório, sobretudo do verapamil, no influxo de cobre indica que o cálcio extracelular exerce uma função importante na tomada de cobre através das membranas destas células epiteliais (CHAVEZ-CROOKER e col., 2001).

O cálcio extracelular possivelmente penetra nas células epiteliais através de canais de cálcio sensíveis a verapamil e nifedipina. Uma vez dentro da célula, o cálcio pode se envolver no transporte de cobre, atuando como substrato antiporte trocando de lugar de forma eletroneutra (transporte estoicométrico $1 \mathrm{Cu}^{2+} / 1 \mathrm{Ca}^{2+}$ ) (CHAVEZ-CROOKER e col., 2001). 
O modelo atualmente aceito para a compreensão de como se dá o influxo de cálcio (apical para basolateral, em brânquias e hepatopâncreas, na pós muda e na glândula antenal, na intermuda) se baseia na entrada passiva deste cátion pela membrana apical, por difusão facilitada (a favor do gradiente de concentração), mediada por um carreador que pode ser eletroneutro ou eletrogênico, ou por meio de difusão simples, através de canais de cálcio dependentes de diferença de potencial e inibidos por verapamil (WHEATLY e col., 2002).

Conforme o tipo de epitélio, o meio extraceluar pode ter diferentes concentrações de cálcio e em todos os casos há sempre um gradiente eletroquímico que favorece a entrada apical passiva de cálcio (WHEATLY e col., 2002). De modo alternativo, o cálcio intracelular pode estimular a entrada de cobre de maneira alostérica, por meio de uma ligação a um sítio regulador independente do cátion antiporte. Desta maneira, o antiporte para cobre pode tomar lugar, usando um substrato intracelular diferente, como magnésio, sódio, hidrogênio, dentre outros. É possível que o cálcio atue tanto como um substrato antiporte como um ativador na mesma célula (CHAVEZ-CROOKER e col., 2001).

A cafeína, conhecida por liberar cálcio proveniente do retículo endoplasmático, afeta a concentração intracelular de cobre por meio do aumento da concentração deste metal disponível no citoplasma celular. Em estudo anterior, SÁ e col. (2010) demonstraram que células de brânquias do caranguejo de água doce Dilocarcinus pagei, incubadas em cafeína, apresentaram um aumento da concentração intracelular de cálcio. Os resultados obtidos no presente estudo demonstram que houve também aumento da concentração intracelular de cobre após adição deste metal em células de brânquias incubadas em cafeína. Portanto, há evidências inequívocas de que o aumento da concentração de cálcio intracelular afeta a homeostase do cobre nas células epiteliais do caranguejo de mangue Ucides cordatus, e tal condição se dá por meio da existência de um trocador Ca/Cu (CHAVEZ-CROOKER e col, 2001). Além disso, sabe-se, também, que o cobre se associa à cafeína, uma droga que estimula o sistema nervoso central, músculos (incluindo o cardíaco) e rins (SPIRO e col., 1989; FALK e col., 1998; FRANSKA, 2008; RIBEIRO e col., 2010).

Como citado anteriormente, a tomada apical de cobre e zinco, nas brânquias, ocorre através do transporte de cálcio apical nas células do epitélio branquial e estudos feitos por GLYNN (2001) indicam que o zinco afeta a permeabilidade apical de cálcio de maneira similar, com inibição da Ca-ATPase. Sugere-se que o mesmo possa ocorrer para a relação entre cobre e cálcio. 
O gradiente de concentração iônica promove a tomada de cálcio pelos canais apicais e é mantido por meio do bombeamento ativo de cálcio para fora da célula. Possivelmente, pela ação de uma Ca-ATPase na membrana basal, no caso de ionócitos em crustáceos decápodas (RAINBOW, 2000).

\section{Vanadato}

$\mathrm{O}$ ortovanadato, $\mathrm{VO}_{4}{ }^{3-}$, atua como um análogo de fosfato de transição, bloqueando a formação de intermediários fosforilados em todas as ATPases do tipo P (dependentes de fósforo) (LIN \& RANDALL, 1993) e a inibição causada pelo vanadato indica uma possível dependência da Cu-ATPase pelo ATP (CHAVEZ-CROOKER e col., 2003 a;b).

A completa inibição da tomada de cobre pela aplicação de $50 \mu \mathrm{mol} / \mathrm{L}$ de vanadato sugere que a P-ATPase, localizada na porção basolateral, é a principal responsável pela tomada de cobre da água (CAMPBELL e col., 1999). No entanto, a similaridade entre a cinética da tomada de cobre, observada no presente estudo, e aquela observada em mamíferos apóia a idéia de que a tomada de cobre pelas brânquias ocorre com auxílio de uma ATPase bastante conservada (CAMPBELL e col., 1999).

A extrusão de cobre através da porção basolateral das células branquiais é mediada por carreadores. Os dados obtidos neste estudo mostram que o transporte de cobre foi inibido por vanadato, sugerindo o envolvimento de uma ATPase do tipo P. No entanto, ainda não se sabe onde exatamente este vanadato atua e também se a Cu-ATPase está presente no complexo de Golgi ou na membrana basolateral (BURY, 2003).

No estudo de SÁ e col. (2010) a tomada de cálcio no caranguejo de água doce Dilocarcinus pagei foi inibida na presença de vanadato, resultando em aumento da concentração de cálcio intracelular. Espera-se, portanto, que quanto maior a atividade de qualquer bomba de cálcio, maior será a proporção da tomada de cobre por esta rota (RAINBOW \& DALLINGER, 1993; RAINBOW, 1995). Porém, neste trabalho, observou-se uma redução da concentração intracelular de cobre na presença de vanadato. Em razão desta observação é possível levantar a hipótese de que a Cu-ATPase, nas células branquiais de Ucides cordatus, não esteja envolvida na extrusão de cobre, mas sim na sua captação do meio extracelular, uma vez que a inibição da Cu-ATPase pelo vanadato reduziu drasticamente a tomada de cobre pela membrana, ao invés de aumentar a concentração do cobre intracelular. Tal hipótese, entretanto, não poderia ser corroborada caso a Cu-ATPase estivesse localizada na 
membrana basolateral e fosse responsável pela extrusão de cobre (GROSELL \& WOOD, 2002; SOLIOZ e col., 1994).

Nossos resultados, portanto, sugerem a presença de uma Cu-ATPase apical em todas as populações de células, tanto de brânquias quanto de hepatopâncreas, confirmada pelo aumento da concentração de cobre intracelular, na presença de ATP, e redução da concentração de cobre, na presença de vanadato. A extrusão de cobre proveniente das células para a hemolinfa aparenta ser um mecanismo de proteção contra o acúmulo excessivo de cobre nas células. Outro mecanismo de proteção consiste na compartimentalização do cobre no interior de organelas, como lisossomos, mitocôndrias e retículo endoplasmático (CHAVEZCROOKER e col., 2001; 2002; 2003 a;b; AHEARN e col., 2004).

É possível concluir que a tomada de cobre pelas células branquiais e do hepatopâncreas do caranguejo de mangue Ucides cordatus é dependente dos mais diversos fatores como as concentrações de sódio, cálcio e hidrogênio, os quais de uma maneira ou outra se encontram interligados, já que, como no caso dos peixes de água doce, a bomba de prótons provém a força motriz para a tomada de sódio. Ademais, tais fatores podem atuar na atividade da $\mathrm{H}^{+}$-ATPase, variando o influxo de sódio, o qual, por sua vez, pode ser secundário (LIN \& RANDALL, 1993). Soma-se a isso o fato de que o sódio pode ser tomado em troca de íons hidrogênio por meio de uma proteína trocadora $\mathrm{Na} / \mathrm{H}$, ou através de um canal de sódio, o qual está associado a uma $\mathrm{H}^{+}$-ATPase, aparentemente de maneira direta, localizada no lado apical das células branquiais (SKAGGS \& HENRY, 2002).

Experimentos com vesículas de membrana basolateral de hepatopâncreas (BLMV) de lagosta revelaram que a tomada de cálcio é maior na presença de ATP e que o vanadato (inibidor genérico da ATPase do tipo P) reduz significativamente a tomada de cálcio, corroborando a ideia da existência de uma ATPase do tipo $P$, dependente de fósforo (WHEATLY e col., 2002). 


\section{CONCLUSAO}

Com base no que foi apresentado neste capítulo, é possível sugerir o seguinte:

- a existência de um canal/carreador epitelial altamente conservado para a regulação do transporte de cobre em células de brânquias e de hepatopâncreas de Ucides cordatus;

- a existência de canais/carreadores similares para a tomada de metais diversos, como prata cobre e zinco, de acordo com o que tem sido reportado por outros investigadores, tanto em animais de água doce quanto de ambiente marinho;

- a tomada de cobre é dependente e independente das concentrações extra e intracelular de cálcio;

- o transporte transmembrana de cobre é dependente da concentração extracelular de sódio, além de ser afetado pela inibição de transportadores e trocadores dependentes de sódio;

- há competição entre cátions divalentes, como no caso do cálcio em relação ao cobre. Porém, também se reconhece a existência de um sistema de cooperação entre estes cátions;

- para que ocorra a regulação das concentrações de cobre intra e extracelular é necessária uma fina interação entre os mais diversos transportadores e de uma fonte de energia, na forma de ATP, para a tomada deste metal vital para todos os organismos, quer sejam plantas, animais ou pertencentes a outros grupos. 
Capítulo 3 - Efeito do cobre no metabolismo energético do caranguejo de mangue Ucides cordatus 


\section{RESUMO}

Os animais necessitam de alimento para prover, dentre outras funções, a energia necessária para permanecerem vivos e manterem os processos físicos em geral, como a contração muscular, por exemplo,, bem como para o crescimento e reprodução. Como os carboidratos são as moléculas biológicas mais abundantes da biosfera, estes são utilizados como material estrutural e também como reserva energética. Antes desta frase caberia uma pequena menção sobre o cobre como poluente e, portanto, a razão de ser da investigação. Caranguejos de mangue Ucides cordatus (machos) foram submetidos a testes agudo (24h e $96 \mathrm{~h}$ ) e crônico (15 dias) de exposição ao $\mathrm{CuSO}_{4}$ na água na concentração final de $\mathrm{Cu}$ de $2 \mathrm{mg} / \mathrm{L}$, onde o grupo controle ficou exposto em água do mar 20\%o durante os 15 dias de exposição. Após o período de testes, os animais foram crio anestesiados para retirada de hemolinfa e urina para dosagem das concentrações de glicose e lactato, e posteriormente foram abertos através da separação dorso-ventral para a retirada do hepatopâncreas e músculo da quela para determinação da concentração de glicogênio em cada um destes tecidos. Os resultados mostraram que houve redução dos valores de concentração de glicose na hemolinfa do caranguejo $(P<0.001)$, quando comparados aos dos grupos controle com $96 \mathrm{~h}$ de exposição, seguido pelo outro grupo pertencente ao teste agudo ( $24 \mathrm{~h}$ de exposição), o qual também apresentou redução em relação ao controle, porém tal redução foi menos acentuada que a observada no grupo $96 \mathrm{~h}$ $(\mathrm{P}<0.05)$. O grupo 15 dias atingiu valores muito próximos do grupo controle, indicando que possivelmente tenha havido aclimatação e reestabelecimento das funções vitais (?) desses caranguejos. Quando os valores de glicose foram analisados na urina dos animais, observou-se que a redução detectada na hemolinfa dos animais $96 \mathrm{~h}$ se deu na forma de um aumento da concentração da glicose na urina, indicando que houve excreção de parte do açúcar, possivelmente a fim de evitar danos fisiológicos e talvez celulares. Em relação aos valores de lactato, observou-se um aumento nos 2 grupos do teste agudo e uma redução no grupo exposto durante 15 dias ao $\mathrm{Cu}$ na água, quando comparados ao grupo controle $(\mathrm{P}<0.05)$, enquanto que a concentração de lactato na urina apresentou valores superiores ao controle para os 2 grupos do teste agudo, porém somente o grupo $24 \mathrm{~h}$ de exposição apresentou $P<0.05$, enquanto que o grupo $96 \mathrm{~h}$ apresentou $\mathrm{P}>0.05$. Além disso, o grupo exposto durante 15 dias apresentou redução dos valores de lactato, com $\mathrm{P}<0.05$, indicando que possivelmente o lactato foi utilizado para obter energia sob condições anaeróbicas, através da quebra de carboidratos em ácido lático. O glicogênio é o principal polissacarídeo armazenado nas células animais, além de ser mais rapidamente mobilizado que gorduras, e, no presente estudo, 
observou-se uma dinâmica bastante diferente entre músculo da quela e hepatopâncreas. Houve aumento acentuado da concentração de glicogênio no músculo dos animais expostos durante $24 h(P<0.05)$, enquanto que os valores para o grupo $96 \mathrm{~h}$ foram reduzidos, porém não estatisticamente diferentes do grupo controle. O grupo 15 dias também apresentou valores bastante similares ao grupo controle. Em relação aos valores obtidos para hepatopâncreas, houve aumento do grupo $24 \mathrm{~h}$, porém sem diferença estatística significativa. Já o grupo $96 \mathrm{~h}$ apresentou leve redução. Porém, o grupo do teste crônico apresentou redução acentuada, indicando que sob tais condições de estresse houve mobilização do glicogênio proveniente do hepatopâncreas.

Palavras-chave: cobre, glicogênio, glicose, lactato, Ucides cordatus 


\section{ABSTRACT}

Animals need food to provide, among other things, enough energy to keep them alive and maintain their vital functions such as muscle contraction, growth and reproduction. Carbohydrates are the most abundant biological molecules in the biosphere and they are used as structural materials and also as a means to store energy. Copper is an essential metal for all living organisms, but it can also be a toxic agent when concentrations are high at sublethal levels. Copper has now been considered a very important pollutant and it is present in the composition of many materials such as algicides, painting materials, and as the main component of some electronics like televisions. Mangrove crabs Ucides cordatus (males) were submitted to acute ( $24 \mathrm{~h}$ and $96 \mathrm{~h}$ ) and chronic ( 15 days) exposures to $\mathrm{CuSO}_{4}$ in water at a final concentration of $2 \mathrm{mg} \mathrm{Cu} / \mathrm{L}$, and a control group was exposed to seawater at $20 \%$ during 15 days. After the experimental period the animals were cryoanesthetized and samples of haemolymph and urine were collected for measuring glucose and lactate concentrations. The animals were subsequently opened by separating their dorsal and ventral portions to remove the hepatopancreas and muscle tissue to determine their glycogen concentrations. The results showed that there was a reduction in the haemolymph glucose concentration in the $96 \mathrm{~h}$ exposure group $(P<0,001)$ when compared to the controls. A reduction was also found in the

$24 \mathrm{~h}$ exposure group when compared to the controls, however this reduction was less pronounced than that observed in the $96 \mathrm{~h}$ exposure group $(\mathrm{P}<0,05)$. The chronically exposed animals showed glucose concentration values similar to the controls, indicating that an acclimatization process might have occurred with the return of the crabs' vital functions. The glucose concentration increased in the urine of the $96 \mathrm{~h}$ exposure group, indicating that part of the sugar was excreted to avoid physiological or cellular damages. Haemolynph lactate concentration increased in the two acutely exposed groups and it reduced in the group exposed for 15 days to $\mathrm{Cu}(\mathrm{P}<0.05)$, while lactate concentrations in the urine of the two acutely exposed groups where higher than the control values. However, only in the $24 \mathrm{~h}$ exposure group $\mathrm{P}$ was $<0.05$ whereas in the $96 \mathrm{~h}$ exposure group $\mathrm{P}$ was $>0.05$. Furthermore, the group exposed for 15 days showed reduction of the lactate values with $P<0.05$, indicating that energy was also obtained under anaerobic conditions, by breaking down carbohydrates into lactic acid. The glycogen is the main polysaccharide stored in animal cells, and it is mobilized quicker than fat. In this study, however, a quite different dynamic was observed between muscles and hepatopancreas. There was an increase in the glycogen concentration in the muscles of animals exposed to 24 hours $(P<0.05)$, and a reduction in the group exposed to 
$96 \mathrm{~h}$, but the values were not statistically different from the controls. The group exposed to 15 days also showed similar values to the controls. In the hepatopancreas the glycogen concentration increased in the $24 \mathrm{~h}$ exposure group, but the values were not statistically different from the controls. There was though a slight reduction in the $96 \mathrm{~h}$ exposure group. However, the chronically exposed group showed a reduction, indicating that under such stressful conditions there was mobilization of glycogen from the hepatopancreas.

Keywords: copper, glycogen, glucose, lactate, Ucides cordatus 


\section{INTRODUÇAO}

Os animais necessitam de alimento (i) para prover a energia necessária para permanecerem vivos e manterem os processos físicos em geral, como, por exemplo, a contração muscular, entre tantos outros, (ii) como matéria-prima para manutenção dos mecanismos celulares e metabólicos e (iii) para crescimento e reprodução. Para uma grande parte dos animais, os processos que requerem energia podem ser completamente satisfeitos somente pela quebra anaeróbia da glicose, cujo rendimento do ponto de vista energético, no entanto, é muito baixo. Para uma outra parcela dos animais, cujas necessidades energéticas são muito mais elevadas, a oxidação completa dos alimentos, com um alto rendimento (energético), é que contribui para suprir tais necessidades. Portanto, a quantidade de oxigênio que consomem pode ser usada como medida do metabolismo energético aeróbio desses animais (SCHMIDT-NIELSEN, 2002).

De modo geral, o termo metabolismo se refere às atividades por meio das quais as células adquirem e utilizam energia enquanto constroem, reorganizam e dividem compostos orgânicos. Tais atividades ajudam cada célula em particular a permanecer viva, crescer e se reproduzir (STARR e col., 2011).

Os carboidratos são as moléculas biológicas mais abundantes na biosfera e são utilizados por algumas células como materiais estruturais,e por outras como uma forma de armazenar energia. São compostos orgânicos que consistem principalmente de carbono, hidrogênio e oxigênio em uma proporção 1:2:1. Os três principais tipos de carboidratos em sistemas vivos são: monossacarídeos, oligossacarídeos e polissacarídeos (STARR e col., 2011).

A cada ano, a fotossíntese converte mais de 100 bilhões de toneladas métricas de gás carbônica $\left(\mathrm{CO}_{2}\right)$ e (água) $\mathrm{H}_{2} \mathrm{O}$ em celulose e outros compostos. Alguns destes carboidratos, como açúcar e amido, são os principais elementos da dieta em muitas partes do mundo, e sua oxidação é a principal via de produção de energia na maioria das células não fotossintéticas (NELSON \& COX, 2011).

A maioria dos carboidratos encontrados na natureza ocorre na forma de polissacarídeos, polímeros de médio a alto peso molecular. Porém, existem carboidratos mais simples, os monossacarídeos, que podem ser oxidados por agentes oxidantes como o íon cúprico $\left(\mathrm{Cu}^{2+}\right)$, quando o carbono do carbonil é oxidado a um grupo carboxil. A glicose e outros açúcares 
capazes de reduzir o íon cúprico são chamados de açúcares redutores (NELSON \& COX, 2011). Os carboidratos "complexos", ou polissacarídeos, são cadeias retas ou ramificadas de muitos monômeros de açúcar - frequentemente centenas de milhares, podendo haver um ou muitos tipos de monômeros em um polissacarídeo, e os mais comuns são celulose, glicogênio e amido. Embora todos consistam em monômeros de glicose, possuem diferenças em suas propriedades químicas devido a diferenças nos padrões de ligação covalente que unem suas unidades de glicose (STARR e col., 2011).

A fermentação e a respiração aeróbia se iniciam com as mesmas reações no citoplasma e essas reações fazem parte da via glicolítica, que converte uma molécula de seis carbonos de glicose em duas moléculas de piruvato, uma molécula orgânica com uma estrutura de três carbonos. A partir desse ponto, as vias de fermentação e respiração aeróbia divergem entre si (STARR e col., 2011).

As reações que acontecem no citoplasma convertem, portanto, uma molécula de glicose em duas moléculas de piruvato, duas moléculas de ATP e duas moléculas de NADH. A glicólise é o primeiro estágio de decomposição de carboidratos, tanto na respiração aeróbia como na fermentação (STARR e col., 2011).

\section{GLICOSE}

As células utilizam glicose como fonte de energia ou material estrutural, mas também como precursora, ou molécula-mãe, que se remodela em outras moléculas (por exemplo: a vitamina C que é derivada da glicose) (STARR e col., 2011).

O papel central da glicose no metabolismo surgiu cedo na evolução. Além disso, a glicose que é considerada um combustível quase que universal, é uma unidade estrutural importante dos organismos atuais, desde microorganismos até seres humanos, e também atua como um precursor amplamente versátil, capaz de suprir uma enorme variedade de intermediários metabólicos em reações de biossíntese (NELSON \& COX, 2011).

A partir do armazenamento da glicose por meio de polímeros de alta massa molecular, como amido e glicogênio, a célula pode estocar grandes quantidades de unidades de hexose, enquanto mantém a osmolaridade citosólica relativamente baixa. Quando a demanda de energia aumenta, a glicose pode ser disponibilizada a partir desses polímeros e utilizada para a produção de ATP de maneira aeróbia ou anaeróbia (NELSON \& COX, 2011). 
Em animais e em vegetais vasculares, a glicose possui quatro destinos principais: $(i)$ síntese de polissacarídeos complexos direcionados ao espaço extracelular; (ii) armazenamento nas células (como polissacarídeo ou como sacarose); (iii) oxidação em compostos de três átomos de carbonos (piruvato), por meio da glicólise, para fornecer ATP e intermediários metabólicos; (iv) oxidação pela via das pentoses-fosfato (fosfoglicano), produzindo ribose-5fosfato para a síntese de ácidos nucléicos e NADPH para processos biossintéticos redutores (NELSON \& COX, 2011).

O suprimento de glicose nem sempre é suficiente e durante períodos longos de jejum, ou após exercício vigoroso, o glicogênio se esgota. Para esses períodos, os organismos precisam de um método para sintetizar glicose a partir de precursores que não são carboidratos. Isso é realizado por uma via chamada de gliconeogênese ("nova formação de açúcar"), que converte em glicose o piruvato e compostos relacionados, com três e quatro carbonos. Os organismos que não têm acesso à glicose de outras fontes devem sintetizá-la e os organismos fotossintéticos a sintetizam inicialmente por meio da redução de $\mathrm{CO}_{2}$ atmosférico a trioses e, em seguida, pela conversão das trioses em glicose. As células não fotossintéticas produzem glicose a partir de precursores simples com três ou quatro átomos de carbono, pelo processo de gliconeogênese, que reverte a glicólise em uma via que utiliza muitas das enzimas glicolíticas (NELSON \& COX, 2011).

Em mamíferos, a gliconeogênese ocorre principalmente no fígado, e em menor extensão no córtex renal e nas células epiteliais que revestem internamente o intestino delgado. A glicose assim produzida passa para o sangue e supre os demais tecidos. Após exercícios vigorosos, o lactato produzido pela glicólise anaeróbia no músculo esquelético retorna para o fígado e é convertido em glicogênio - um circuito chamado de Ciclo de Cori (NELSON \& COX, 2011)

A glicólise ocorre comumente em músculos de vertebrados quando a demanda de energia durante exercícios intensos excede o oxigênio disponível. Quando um mol de glicose, por meio de reações bioquímicas intermediárias, é degradado em dois mols de ácido lático e dois mols de ATP são sintetizados fincado disponíveis para suprir energia. O produto da quebra anaeróbia da glicose é, portanto, pequeno, não chegando a $6 \%$ do que estaria disponível a partir da oxidação completa da glicose (SCHMIDT-NIELSEN, 2002).

Na glicólise, a desidrogenação de duas moléculas de gliceraldeído-3-fosfato, derivada de cada molécula de glicose, permite a conversão de duas moléculas de $\mathrm{NAD}^{+}$em duas de NADH. 
Como a redução de duas moléculas de piruvato em duas de lactato regenera duas moléculas de $N A D^{+}$, não ocorre variação líquida de $\mathrm{NAD}^{+}$ou NADH neste processo.

A oxidação do piruvato é um processo catabólico importante, mas o piruvato também tem destinos anabólicos, podendo, por exemplo, prover o esqueleto carbônico para a síntese do aminoácido alanina ou para a síntese de ácidos graxos. Com exceção de algumas variações entre as bactérias, o piruvato formado na glicólise é mais adiante metabolizado por três rotas catalíticas. Em organismos aeróbios ou em tecidos em condições aeróbias, a glicólise é apenas o primeiro estágio da degradação completa da glicose. O piruvato é oxidado, com a perda de seu grupo acetil-coenzima $A$, que então é completamente oxidado a $\mathrm{CO}_{2}$ no ciclo do ácido cítrico e, a partir daí, os elétrons originados dessas oxidações são transferidos ao (oxigênio) $\mathrm{O}_{2}$ por uma cadeia de transportadores na mitocôndria, formando $\mathrm{H}_{2} \mathrm{O}$, e a energia liberada nas reações de transferência de elétrons impulsiona a síntese de ATP na mitocôndria da célula (NELSON \& COX, 2011).

A respiração aeróbia termina dentro das mitocôndrias, onde o oxigênio é o aceptor final de elétrons da cadeia de transferência, denominada fosoforilação oxidativa. A cada respiração, as células recebem um suprimento de oxigênio e o redimento energético, o qual resulta na formação de 36 moléculas de ATP, é muito maior que o obtido nas vias de fermentação, que terminam com um resultado líquido de dois ATPs por glicose (STARR e col., 2011).

\section{LACTATO}

O segundo estágio da respiração aeróbia finaliza a decomposição de glicose que como na glicólise ocorre dentro das mitocôndrias e inclui dois conjuntos de reações, a formação de acetil-CoA e o ciclo de Krebs, que decompõem os piruvato de glicólise. Todos os átomos de carbono que fizeram parte da glicose terminam em $\mathrm{CO}_{2}$, que deixa a célula.

\section{formação de acetil-CoA}

As reações de segundo estágio começam quando dois piruvatos formados a partir da glicólise entram na matriz mitocondrial. Uma enzima divide cada piruvato de três carbonos em uma molécula de $\mathrm{CO}_{2}$ e um grupo acetil de dois carbonos. $\mathrm{O}_{2}$ sai da célula e o grupo 
acetil combina com uma coenzima, formando acetil-CoA. Elétrons e íons de hidrogênio liberados pela reação se combinam com a coenzima $\mathrm{NAD}^{+}$formando moléculas de NADH.

\section{Ciclo de krebs}

O ciclo de Krebs decompõe acetil-CoA em CoA. É uma via com sequência de reações mediadas por enzimas produzindo o oxaloacetato com quatro átomos de carbono, o qual, por sua vez, é o substrato da primeira reação (STARR e col., 2011).

O terceiro estágio da respiração aeróbia, a fosforilação de transferência de elétrons, também ocorre dentro das mitocôndrias e começa com as coenzimas $\mathrm{NADH}$ e FADH $\mathrm{F}_{2}$ que se reduziram nos dois primeiros estágios da respiração aeróbica, doando suas cargas de elétrons e íons de hidrogênio para cadeias transportadoras de elétrons na membrana mitocondrial interna. Ao final das cadeias transportadoras de elétrons, o oxigênio aceita elétrons e se combina com hidrogênio, formando água (STARR e col., 2011).

Durante contrações vigorosas, o músculo esquelético trabalha com baixo suprimento de oxigênio (hipóxia) em relação à demanda imposta. Nesses casos, NADH não pode ser reoxidado a $\mathrm{NAD}^{+}$; no entanto, $\mathrm{NAD}^{+}$é necessário como aceptor de elétron para a oxidação do piruvato. Nessas condições, o piruvato é reduzido a lactato, recebendo os elétrons do NADH, regenerando dessa forma o $\mathrm{NAD}^{+}$necessário para a continuidade da glicólise. Em certos tecidos e células, como as da retina e eritrócitos, há conversão da glicose a lactato mesmo em condições aeróbias, lembrando que o lactato também é produto da glicólise em condições anaeróbias, em alguns microorganismos (NELSON \& COX, 2011).

O ciclo de Krebs (ácido cítrico ou tricarboxílico) consiste em uma série de reações, localizadas na mitocôndria, que efetuam a oxidação do resíduo acetil até $\mathrm{CO}_{2}$, liberando equivalentes de hidrogênio, os quais finalmente formam água. Quase todas as moléculas de carboidratos e gorduras formam acetil-CoA durante o catabolismo oxidativo, além de muitos aminoácidos provenientes do desdobramento das proteínas. Além disso, acetil-CoA serve como fonte de unidades de acetil nos processos anabólicos responsáveis pela síntese de ácidos graxos de cadeia longa, colesterol e outros esteróides, e também corpos cetônicos. A função principal do ciclo do ácido cítrico é agir como percurso final comum para a oxidação de carboidratos, lipídios e proteínas, uma vez que a glicose, ácidos graxos e muitos aminoácidos são metabolizados a acetil-CoA. Além disso, é o mecanismo pelo qual a maior parte da energia 
livre liberada durante a oxidação de carboidratos, lipídios e aminoácidos se torna disponível para outros processos (HARPER e col., 1982).

A terceira rota principal do catabolismo do piruvato leva à produção de etanol. Em alguns tecidos vegetais e em certos invertebrados, protistas e microorganismos, como a levedura da fabricação da cerveja e do pão, o piruvato é convertido, em hipóxia ou sob condições anaeróbias, em etanol e $\mathrm{CO}_{2}$, um processo chamado de fermentação etanólica (alcoólica) (NELSON \& COX, 2011).

Todos os constituintes químicos do ciclo, desde o citrato ao oxaloacetato, permitem a produção efetiva de glicose no fígado e rins, órgãos que contêm um conjunto completo de enzimas necessárias para a gliconeogênese (HARPER e col, 1982).

\section{Lactato em Condições Anaeróbias}

Um processo comum para obter energia sob condições anaeróbias é a quebra de carboidrato $\left(\mathrm{C}_{6} \mathrm{H}_{12} \mathrm{O}_{6}\right)$ em ácido lático $\left(2 \mathrm{C}_{3} \mathrm{H}_{6} \mathrm{O}_{3}\right)(\mathrm{SCHMIDT-NIELSEN,} \mathrm{2002)} \mathrm{e} \mathrm{quando} \mathrm{os} \mathrm{tecidos}$ animais não podem ser supridos com oxigênio suficiente para realizar a oxidação aeróbia do piruvato e de gerar moléculas de $\mathrm{NADH}$ durante a glicólise, $\mathrm{NAD}^{+}$é regenerado a partir da $\mathrm{NADH}$, pela redução do piruvato a lactato. Como mencionado anteriormente, alguns tecidos e tipos celulares (como os eritrócitos, que não possuem mitocôndria e, portanto, não podem oxidar piruvato até $\mathrm{CO}_{2}$ ) produzem lactato a partir de glicose, mesmo em condições aeróbias (NELSON \& COX, 2011).

Para a redução de piruvato em lactato, com a concomitante oxidação de NADH, é necessária a presença da enzima glicolítica lactato desidrogenase (LDH), e o aumento de sua atividade pode resultar em um aumento do metabolismo anaeróbio dependente de carboidratos oriundos de crustáceos expostos a contaminantes como cobre na água (FINGERMAN e col., 1998; NELSON \& COX, 2011).

Embora a conversão de glicose em lactato compreenda duas etapas de oxidaçãoredução, não ocorre variação líquida no estado de oxidação do carbono; tanto na glicose $\left(\mathrm{C}_{6} \mathrm{H}_{12} \mathrm{O}_{6}\right)$ como no ácido lático $\left(\mathrm{C}_{3} \mathrm{H}_{6} \mathrm{O}_{3}\right)$, a relação $\mathrm{H}$ : $\mathrm{C}$ é a mesma. Todavia, parte da energia da molécula de glicose é extraída pela sua conversão em lactato e é o suficiente para dar um rendimento líquido de duas moléculas de ATP para cada molécula de glicose consumida (NELSON \& COX, 2011). 


\section{GLICOGÊNIO}

Como a maior parte da glicólise anaeróbia depende de glicogênio (e não de glicose) como substrato, serão gerados três mols de ATP a partir da formação de dois mols de ácido lático por mol de glicosil. A razão pela qual uma molécula de glicosil gera mais energia que uma molécula de glicose é que parte da energia gerado a partir do glicosil é usada na síntese de glicogênio e isso elimina a etapa que requer energia na quebra do ácido lático (SCHMIDTNIELSEN, 2002).

O glicogênio - que é equivalente ao amido nas plantas - é o principal polissacarídeo de armazenamento das células animais. É um polímero que contém subunidades de glicose unidas por ligações $\alpha 1-4$ e com ligações $\alpha 1-6$ nas ramificações, e é mais ramificado extensivamente (em média a cada 8 a 12 resíduos) porém mais compacto que o amido (NELSON \& COX, 2011). Como os ácidos graxos geram mais que o dobro de energia que os carboidratos, os primeiros são mais adequados para o armazenamento de energia. Contudo, existem exceções a esta regra. Para os animais que não se movimentam, como as ostras e mariscos, o glicogênio é usado como substrato de reserva (SCHMIDT-NIELSEN, 2002; STARR e col., 2011).

O glicogênio, especialmente abundante no fígado, onde pode constituir até $7 \%$ do peso líquido, também está presente no músculo esquelético. Nos hepatócitos, é encontrado em grandes grânulos, os quais são agrupamentos de grânulos menores compostos por moléculas únicas de glicogênio, altamente ramificadas. Tais grânulos também são firmemente ligados às enzimas responsáveis pela síntese e degradação do glicogênio. Quando o glicogênio é utilizado como fonte de energia, as unidades de glicose são removidas uma de cada vez, a partir das extremidades não redutoras, e as enzimas de degradação que atuam somente em extremidades não redutoras podem trabalhar simultaneamente nas muitas ramificações, acelerando a conversão do polímero a monossacarídeos de glicose (NELSON \& COX, 2011).

O glicogênio é, provavelmente, uma substância de reserva mais adequada que a gordura, porque os animais são frequentemente expostos a condições de baixo ou nenhum oxigênio e, na ausência deste, o glicogênio poderá gerar energia pela sua quebra até o ácido láctico. Porém, seu armazenamento envolve mais peso, não só por causa do seu baixo conteúdo de energia quando comparado com o da gordura, mas também porque o glicogênio é depositado nas células com uma quantidade considerável de água. A vantagem do glicogênio é dupla: (i) pode fornecer combustível para o metabolismo de carboidrato muito rapidamente, 
enquanto a mobilização de gordura é lenta; e, talvez o mais importante, (ii) o glicogênio pode prover energia sob condições anaeróbias (SCHMIDT-NIELSEN, 2002).

\section{ESTRESSE}

Respostas ao estresse ocorrem em vertebrados quando estes são expostos a condições ambientais fora do seu domínio fisiológico normal. Incialmente, o estresse é relacionado à aclimatação e sua regulação se dá em escala de tempo curto. Porém, durante exposição crônica, o estresse possui efeitos adversos a um número grande de funções, como, por exemplo, o metabolismo energético (ELWOOD e col., 2009).

A contaminação do meio ambiente representa uma ameaça para as espécies aquáticas do planeta. Sugere-se que os contaminantes ambientais consistem numa ameaça à vida desde o início da era industrial (FINGERMAN e col., 1998). Normalmente, os metais estão presentes no ambiente marinho em concentrações muito baixas, mas a interferência antropogênica, principalmente nas regiões costeiras (atividade mineira ou processamento de produtos químicos e metais), contribui para a elevação desses níveis (HEBEL e col., 1999). Como os metais constituem uma das principais fontes de poluição, um grande número de suas características ambientais (incluindo propriedades biológicas) é profundamente influenciado pelos metais (HUANG \& SHINDO, 2000).

Aparentemente, os metais em baixas concentrações provavelmente atuam muito mais por meio de hormônios e/ou distúrbios enzimáticos (preferencialmente) do que por meio de outras rotas, enquanto que concentrações elevadas podem, através de intensa produção de radicais livre e rápidos danos a vários sistemas, resultar em hipóxia e alteração no balanço eletrolítico dos animais (SRIVASTAVA, 1982). Alguns poucos estudos têm sido feitos com processos de desregulação endócrina (FINGERMAN e col., 1998), mas respostas hiperglicemiantes em diversas espécies de crustáceos expostas a diversos poluentes, incluindo alguns pesticidas, hidrocarbonetos e metais pesados, têm sido reportadas por alguns autores (FINGERMAN e col., 1998, RODRIGUEZ e col., 2007).

Por exemplo, o cobre, um elemento traço essencial para crustáceos aquáticos (presente em enzimas e importante para a funcionalidade da hemocianina, que nos crustáceos e outros invertebrados é o pigmento respiratório responsável pelo transporte de oxigênio), está 
presente no ambiente marinho em concentrações próximas de $0,1 \mu \mathrm{g} \mathrm{Cu} / \mathrm{L}$, mas concentrações maiores são encontradas no Mar do Norte (0,2 a 2,6 $\mathrm{gg} \mathrm{Cu} / \mathrm{L})$ e em alguns estuários do Reino Unido (2 a 3 mg Cu/L) (DUINKER \& NOLTING, 1982; MORRIS, 1984). Em concentrações que excedem o valor essencial que é variável de organismo para organismo, o cobre é altamente tóxico (HARRIS, 1991; LAWSON e col., 1995). Portanto, espécies que habitam áreas estuarinas e costeiras, como o caranguejo Carcinus maenas (L.), estão claramente em risco em decorrência dos efeitos tóxicos do cobre e para serem tóxicos, os metais precisam estar biodisponíveis. Estudos recentes revelaram a existência de rotas de tomada de cobre nos crustáceos que não a ingestão via dieta, e têm identificado as brânquias como os locais principais da tomada de cobre (HEBEL e col., 1997; RAINBOW \& BLACK, 2005).

A alteração endócrina causada por poluentes, como compostos estrogênicos, pesticidas clorados, herbicidas e hidrocarbonetos de petróleo, metais pesados, pode ser observada em diferentes níveis fisiológicos: (i) alterando (inibindo ou estimulando) a secreção de hormônios, cujo possível efeito está relacionado a mecanismos que controlam tanto a liberação de hormônios de células endócrinas quanto a síntese desses hormônios; (ii) interferindo na interação hormônio-receptor, onde, indiretamente, tais compostos podem interferir por meio de diversos mecanismos em qualquer etapa do caminho da transdução de um hormônio, alterando desse modo o efeito final, ao atuar tanto como agonista quanto como antagonista; e (iii) modificando o metabolismo de hormônios circulantes pelo aumento ou redução de sua taxa de excreção e/ou biotransformação no fígado, hepatopâncreas ou outros órgãos. (RODRIGUEZ e col., 2007).

Assim como o estresse nos vertebrados provoca uma cascata de eventos, levando à produção de cortisol e/ou corticosterona, os hormônios da glândula adrenal apresentam um grande número de efeitos, incluindo a conversão de glicogênio em glicose, os quais podem ser usados numa fuga ou numa resposta à luta. Portanto, níveis desses hormônios glicocorticoides são frequentemente usados como indicadores do bem-estar dos vertebrados (BATESON \& BRADSHAW, 1997; JONGMAN e col., 2005; ELWOOD e col., 2009). 


\section{OBJETIVOS}

\section{Geral}

O presente estudo teve por objetivo geral a determinação dos efeitos do cobre presente na água circundante no metabolismo energético do caranguejo de mangue Ucides cordatus, uma vez que a presença de contaminantes na água afeta a osmo e ionorregulação, assim como alteração da regulação de transporte poderá afetar o fornecimento de energia para o animal.

\section{Específicos}

- Para esse fim, determinou-se as concentrações de glicose e lactato em amostras de hemolinfa e urina, por meio de sistema enzimático colorimétrico.

- Para corroborar os resultados obtidos, foram também determinados os valores de concentração de glicogênio em amostras de hepatopâncreas (análogo ao fígado) e músculo da quela, por meio de método colorimétrico. 


\section{PARTE EXPERIMENTAL}




\section{MATERIAL E METODOS}

\section{ANIMAIS}

Neste estudo, utilizou-se 40 machos de Ucides cordatus, com massa corpórea média de ordem de 156,00 \pm 4,61 g, coletados no estuário próximo à Praia dos Pescadores, Itanhaém, Sul do Estado de São Paulo, Brasil. A Estância Balneária de Itanhaém compreende uma área de 597,4 km² $^{2}$ 46 47' 15" Oeste e 24 11' 08' Sul, e está situada num ecossistema, o mangue, que consiste na transição entre terra e mar, tipicamente encontrado em regiões tropicais e subtropicais (IGARASHI,2008).

Após a coleta, os caranguejos foram aclimatados no Biotério da Universidade Presbiteriana Mackenzie durante sete dias em água do mar em salinidade 20\%, 12C:12E, $25 \pm$ $1^{\circ} \mathrm{C}$, e alimentados com alface e carne moída em dias alternados. Somente após o período de aclimatação, os experimentos com a presença de cobre na água foram realizados.

\section{EXPERIMENTOS}

Os 40 caranguejos machos foram aleatoriamente divididos em quatro grupos (Controle, 24h, 96h e 15 dias de exposição ao cobre na água) e, antes de serem colocados em aquários de $15 \mathrm{~L}$ com paredes encapadas de preto, os animais foram pesados em balança Denver Instrument Company TR-402, bem como logo após o término de cada experimento, para haver controle da massa dos indivíduos ao término dos experimentos realizados com cada grupo experimental, a qual não sofreu variação significativa ao longo dos dias de experimento.

Em cada aquário de $15 \mathrm{~L}$ foram colocados $5 \mathrm{~L}$ de água do mar $20 \%$ o para que os animais não ficassem cobertos de água (sendo este mais um fator de estresse evitado) e para não impedir a sua rotina diária de imersão e emersão. A troca de água foi feita diariamente, com a adição de $5 \mathrm{mg} / \mathrm{L} \mathrm{CuSO}_{4}$ para obter $2 \mathrm{mg} / \mathrm{L}$ cobre, a fim de garantir a mesma exposição de cobre à todos os animais com aeração constante para todos os aquários. 
Ao final dos experimentos e de acordo com seus respectivos intervalos de tempo de exposição (24h, 96h e 15 dias), os animais foram crio-anestesiados para dessensibilização durante 15 a 20 minutos em freezer comum. Alíquotas de hemolinfa e urina foram retiradas, com o auxílio de seringas inseridas no último pereiópodo e no pedúnculo ocular, respectivamente. Após a retirada dos fluidos supramencionados, os animais foram sacrificados por meio da separação manual das partes dorsal e ventral, e, em seguida, retirou-se alíquotas de brânquias, hepatopâncreas e músculo da quela, para demais experimentos que serão citados nos capítulos subsequentes.

Após o processamento das amostras, as alíquotas de $10 \mu \mathrm{L}$ de hemolinfa e urina foram utilizadas diretamente, sem prévio processamento para a determinação das concentrações de glicose e lactato através de método colorimétrico. Para a determinação de glicogênio, foram pesados $50 \mathrm{mg}$ de hepatopâncreas e $100 \mathrm{mg}$ de músculo da quela, respectivamente e as amostras foram levadas ao espectrofotômetro Thermospectronic Genesys 10UV, para leitura em comprimentos de onda adequados a cada composto analisado. 


\section{Determinação dos Substratos}

\section{GLICOSE}

Para a dosagem de glicose na hemolinfa e urina dos caranguejos expostos a $2 \mathrm{ppm} \mathrm{Cu}$ na água, foi utilizado um sistema enzimático por método cinético ou de ponto final (Kit PAP Liquiform 84). Este último foi o escolhido e tem como princípio a catalisação da oxidação da glicose pela glicose oxidase, por meio da reação:

$$
\text { GLICOSE }+\mathrm{O}_{2}+\mathrm{H}_{2} \mathrm{O} \quad \text { ácido glucônico }+\mathrm{H}_{2} \mathrm{O}_{2}
$$

, onde o peróxido de hidrogênio formado reage com 4-aminoasitipirina e fenol, sob a ação catalisadora da peroxidase, por meio de uma reação oxidativa de acoplamento, formando uma antipirilquinonimina vermelha, cuja intensidade de cor é proporcional à concentração de glicose na amostra.

$2 \mathrm{H}_{2} \mathrm{O}_{2}+4$-aminoantipirina + fenol antipirilquinonimina $+4 \mathrm{H}_{2} \mathrm{O}$

O método escolhido foi o GOD-Trinder, com a realização dos testes:

\begin{tabular}{|c|c|c|c|}
\hline & Reagente 1 & Padrão & Amostra \\
\hline BRANCO & $1 \mathrm{~mL}$ & ------------ & ----------- \\
\hline PADRÃO & $1 \mathrm{~mL}$ & $10 \mathrm{uL}$ & -------- \\
\hline AMOSTRA & $1 \mathrm{~mL}$ & --------- & $10 \mathrm{uL}$ \\
\hline
\end{tabular}

, nos quais todos os tubos foram misturados vigorosamente e incubados em banho-maria a 37 ํㅡ, durante 15 minutos, onde o nível da água era superior ao nível dos reagentes nos tubos de ensaio e os valores da concentração de glicose $(\mathrm{mg} / \mathrm{mL})$ foram determinados em absorbância de $505 \mathrm{~nm}$.

Para uma melhor determinação dos dados, foi feita uma curva padrão para a glicose, e os valores obtidos em $\mathrm{mg} / \mathrm{mL}$ foram transformados para $\mathrm{mM}$, com diluição 100x.

\begin{tabular}{|c|c|}
\hline Concentração de Glicose $(\mathrm{mg} / \mathrm{mL})$ & Absorbância \\
\hline 0 & 0 \\
\hline 0,1 & 0,042 \\
\hline 0,2 & 0,072 \\
\hline 0,3 & 0,125 \\
\hline 0,4 & 0,158 \\
\hline
\end{tabular}




\section{LACTATO}

Para a dosagem de lactato na hemolinfa e urina dos caranguejos expostos a $2 \mathrm{mg} / \mathrm{L} \mathrm{Cu}$ na água, foi utilizado um sistema UV enzimático, contendo no seu meio a enzima lactato desidrogenase.

Para o desenvolvimento da técnica, foram utilizados 3 tubos:

\begin{tabular}{|c|c|c|c|}
\hline & Monorreagente & Água & Padrão \\
\hline BRANCO & $1 \mathrm{~mL}$ & $10 \mathrm{uL}$ & ---------- \\
\hline PADRÃO & $1 \mathrm{~mL}$ & ----------- & $10 \mathrm{~L}$ \\
\hline
\end{tabular}

\begin{tabular}{|c|c|c|}
\hline & Monorreagente & Amostra \\
\hline AMOSTRA & $1 \mathrm{~mL}$ & $10 \mathrm{uL}$ \\
\hline
\end{tabular}

, onde os tubos foram homogeneizados suavemente, incubados durante 5 minutos à $37^{\circ} \mathrm{C}$ e a absorbância medida em $340 \mathrm{~nm}$, acertando o zero do aparelho com o tubo BRANCO.

Para uma melhor determinação dos dados, foi feita uma curva padrão para lactato, e os valores obtidos em $\mathrm{mg} / \mathrm{dL}$ foram transformados em $\mathrm{mM}$, com diluição de 100x das amostras.

\begin{tabular}{|c|c|}
\hline Concentração de Lactato $(\mathrm{mg} / \mathrm{mL})$ & Absorbância \\
\hline 0 & 0 \\
\hline 0,09 & 0,052 \\
\hline 0,25 & 0,144 \\
\hline 0,50 & 0,300 \\
\hline 0,90 & 0,520 \\
\hline
\end{tabular}




\section{GLICOGÊNIO}

Para a determinação da concentração de glicogênio nas amostras de hepatopâncreas e músculo da quela de caranguejos expostos a $2 \mathrm{mg} / \mathrm{L}$ de cobre na água foi utilizado um protocolo baseado no trabalho de BIDINOTTO e col., 1997.

Para a extração do glicogênio das amostras, foram utilizados $50 \mathrm{mg}$ de hepatopâncreas e $100 \mathrm{mg}$ de músculo de quela, com adição de $1 \mathrm{~mL}$ de $\mathrm{KOH} 6 \mathrm{~N}$, mantendo sempre as amostras à -20 ․ C. Os tubos contendo as amostras foram fervidos em banho-maria durante 4 minutos e, após o aquecimento, as amostras foram homogeneizadas em vórtex para completa dissolução das amostras.

Para o isolamento do glicogênio, retirou-se uma alíquota de $250 \mu \mathrm{L}$ da amostra, a qual foi transferida para um tubo, onde se acrescentou $3 \mathrm{~mL}$ de álcool $95 \%$, com posterior homogeneização em vórtex para, então, acrescentar-se $10 \mu \mathrm{L}$ de $\mathrm{K}_{2} \mathrm{SO}_{4} 10 \%$. Misturou-se tudo novamente no vórtex e, em seguida, centrifugou-se o conteúdo a 1500g, durante 3 minutos, para, então, descartar o sobrenadante. Após esta última etapa, adicionou-se $2.5 \mathrm{~mL}$ de água deionizada ao pellet para completa dissolução. Após a dissolução do pellet, retirou-se uma alíquota de $100 \mu \mathrm{L}$ de amostra, à qual se adicionou $700 \mu \mathrm{L}$ de fenol $3 \%$, e se misturou tudo novamente no vórtex. Para finalizar a preparação das amostras, adicionou-se $2 \mathrm{~mL}$ de $\mathrm{H}_{2} \mathrm{SO}_{4}$ para nova homogeneização. Como tal mistura aquece muito, é necessário aguardar aproximadamente 10 minutos para as leituras, em uma absorbância da ordem de $480 \mathrm{~nm}$.

Para a determinação da concentração de glicogênio, BIDINOTTO e col. (1997) se basearam no método GLICOSIL/GLICOSE, proposto por DUBOIS (1956). Foi feita uma curva padrão de glicose (100 nM) com 7 pontos, incluindo o tubo BRANCO, de acordo com o mesmo processo feito nas amostras experimentais.

\begin{tabular}{|c|c|}
\hline Concentração de Glicose $(\mathrm{nM})$ & Absorbância \\
\hline 0 & 0,108 \\
\hline 0,01 & 0,169 \\
\hline 0,02 & 0,174 \\
\hline 0,04 & 0,259 \\
\hline 0,06 & 0,377 \\
\hline 0,08 & 0,436 \\
\hline 0,1 & 0,487 \\
\hline
\end{tabular}




\section{Análise dos Dados}

Todos os resultados foram plotados utilizando o programa Prism Graph Pad 5 (Graph Pad Softwarre Inc, La Jolla, EUA) e analisados com auxílio do programa Sigma Stat 3.1.

Aplicou-se num primeiro momento o teste de análise de variância (ANOVA) para todos os resultados obtidos e após os testes de normalidade para cada variável, foi aplicado o teste Kruskal-Wallis seguido pelo teste de Dunn's para os dados obtidos de glicose e lactato na urina e glicogênio no hepatopâncreas, uma vez que o teste de normalidade falhou.

Para os dados de concentração de glicose e lactato na hemolinfa dos caranguejos, assim como a concentração de glicogênio no músuclo da quela, aplicou-se o teste Holm-Sidak após o teste ANOVA, uma que vez o que o teste para normalidade das amostras foi realizado com sucesso, onde para todas as figuras letras, números e símbolos diferentes, indicam diferença estatística significativa.

Já para os resultados que comparam os valores de glicose e lactato pra hemolinfa e urina, assim como os valores de glicogênio para hepatopâncreas e músculo da quela, aplicouse o teste ANOVA seguido do teste T. 
RESULTADOS

A figura 1 representa a concentração de glicose $(\mathrm{mM})$ na hemolinfa do caranguejo de mangue durante os períodos agudo ( $24 \mathrm{~h}$ e $96 \mathrm{~h}$ ) e crônico (15 dias) de experimentação bem como os animais utilizados como controle, e obteve-se como diferença estatística significativa $p<0,05, p<0,001$ e $p>0,05$, respectivamente para a comparação entre os grupos experimentais e controle, e observa-se que houve então bastante variação quando comparados os grupos de tratamento e grupo controle. Os animais expostos ao cobre durante $96 \mathrm{~h}$ foram os que apresentaram maior redução da concentração de glicose na hemolinfa com diferença estatística de $p<0,01$ e $p<0,001$ para os grupos $24 \mathrm{~h}$ e 15 dias, seguido pelo grupo exposto durante $24 \mathrm{~h}$ ao cobre na água, enquanto que o grupo exposto durante 15 dias atingiu valores próximos ao do controle e a comparação entre grupos $24 \mathrm{~h}$ e 15 dias experimentais não apresentaram diferença estatística significativa $(p>0,05)$.

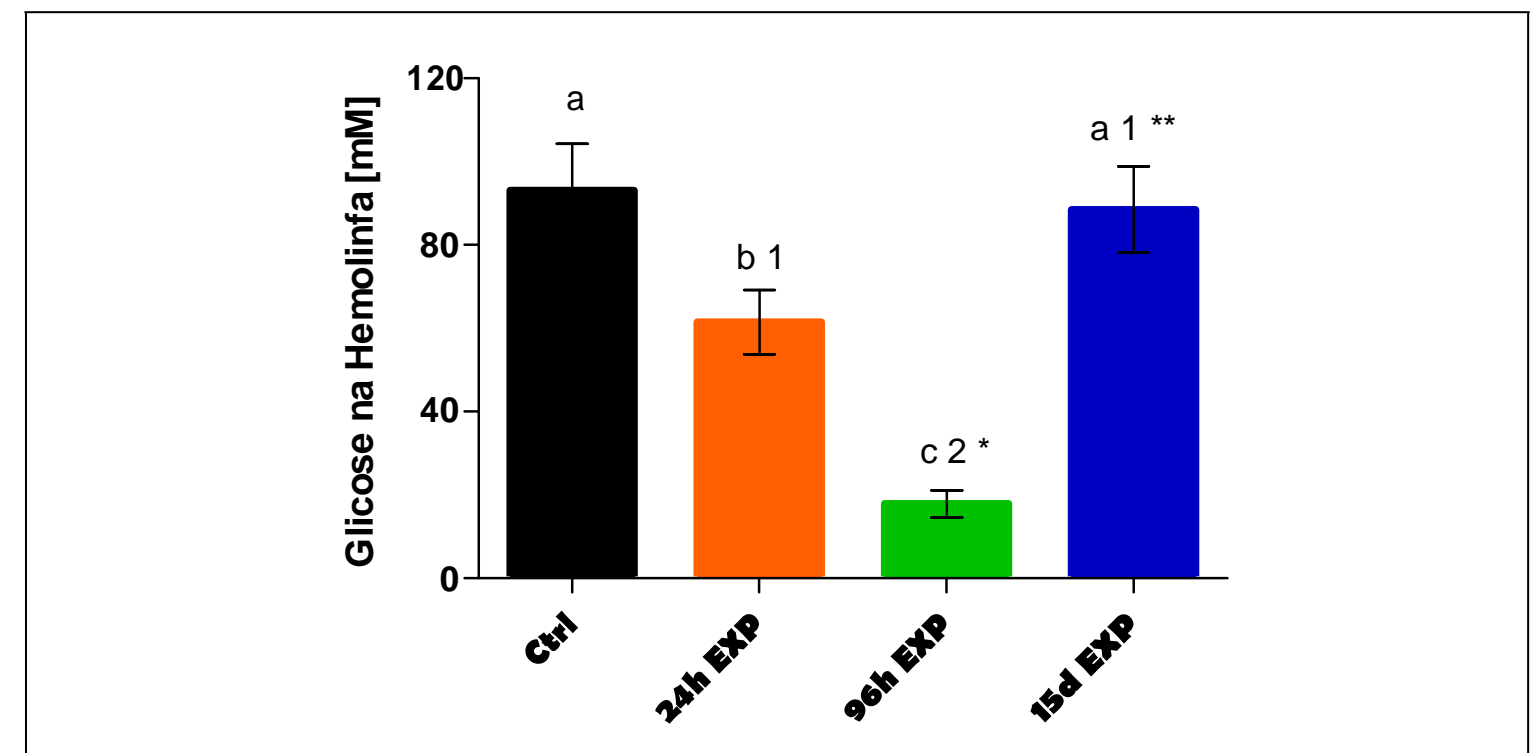

Figura 1: Determinação da concentração de glicose $(\mathrm{mM})$ em amostras de hemolinfa do caranguejo de mangue Ucides cordatus submetidos a testes agudo e crônico de exposição a $5 \mathrm{mg} / \mathrm{L} \mathrm{CuSO}_{4}$ na água durante (24h e $96 \mathrm{~h}$ ) e 15 dias, respectivamente, com $n=10$. 
A figura 2 indica a concentração de glicose $(\mathrm{mM})$ na urina do caranguejo Ucides cordatus durante os tratamentos controle, agudo e crônico e pode-se observar que no grupo experimental 96h, houve aumento da liberação de glicose na urina, seguido pelo grupo 15 dias experimental, indicando que os valores obtidos do controle em relação ao grupo experimental $24 \mathrm{~h}$ não foram estatisticamente significativos, bem como quando comparados os grupos controle e 15 dias de exposição ao cobre na água $(p>0,05)$. Já com os valores obtidos entre os grupos experimentais (agudo e crônico) é possível observar que os grupos experimentais $96 \mathrm{~h}$ e 15 dias de exposição foram estatisticamente significativos $(p<0,05)$ quando comparados com 24h, porém entre si não o são.

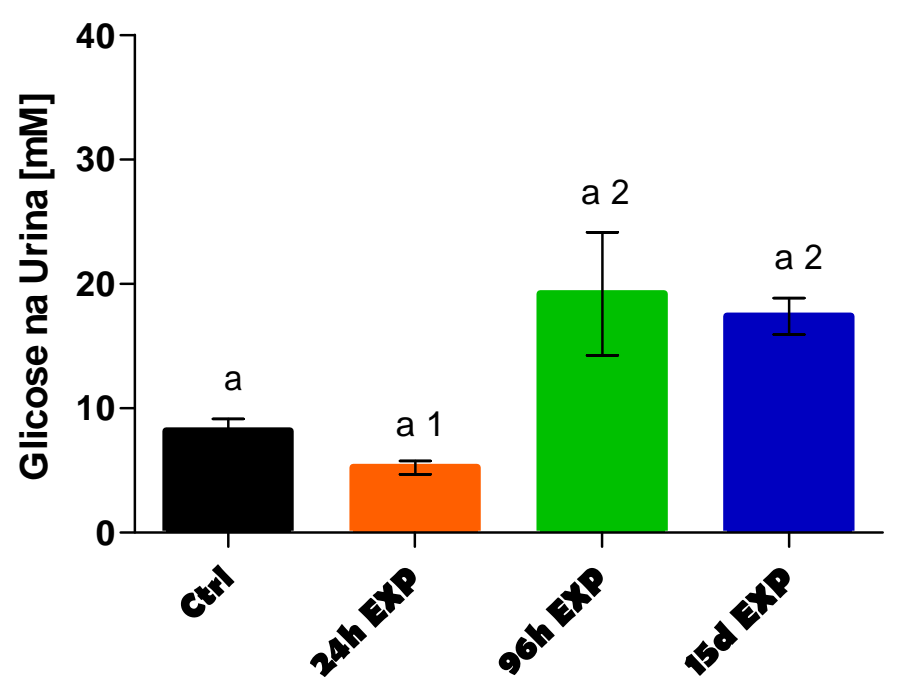

Figura 2: Determinação da concentração de glicose $(\mathrm{mM})$ em amostras de urina do caranguejo de mangue Ucides cordatus submetidos a testes agudo e crônico exposição a $5 \mathrm{mg} / \mathrm{L} \mathrm{CuSO}{ }_{4}$ na água durante (24h e $96 \mathrm{~h}$ ) e 15 dias, respectivamente, com $n=10$. 
A figura 3 demonstra que não há excreção de glicose acima das concentrações encontradas na hemolinfa dos animais, embora a excreção de glicose no grupo $96 \mathrm{~h}$ tenha sido levemente superior à glicose na hemolinfa, porém sem diferença estatística significativa $(p>0,05)$.

Já para os grupos controle, $24 \mathrm{~h}$ e 15 dias de exposição ao cobre na água apresentam diferenças estatísticas quando comparados os valores de hemolinfa e urina com $p<0,01$ para grupo controle e $p<0,001$ para os grupos $24 \mathrm{~h}$ e 15 dias.

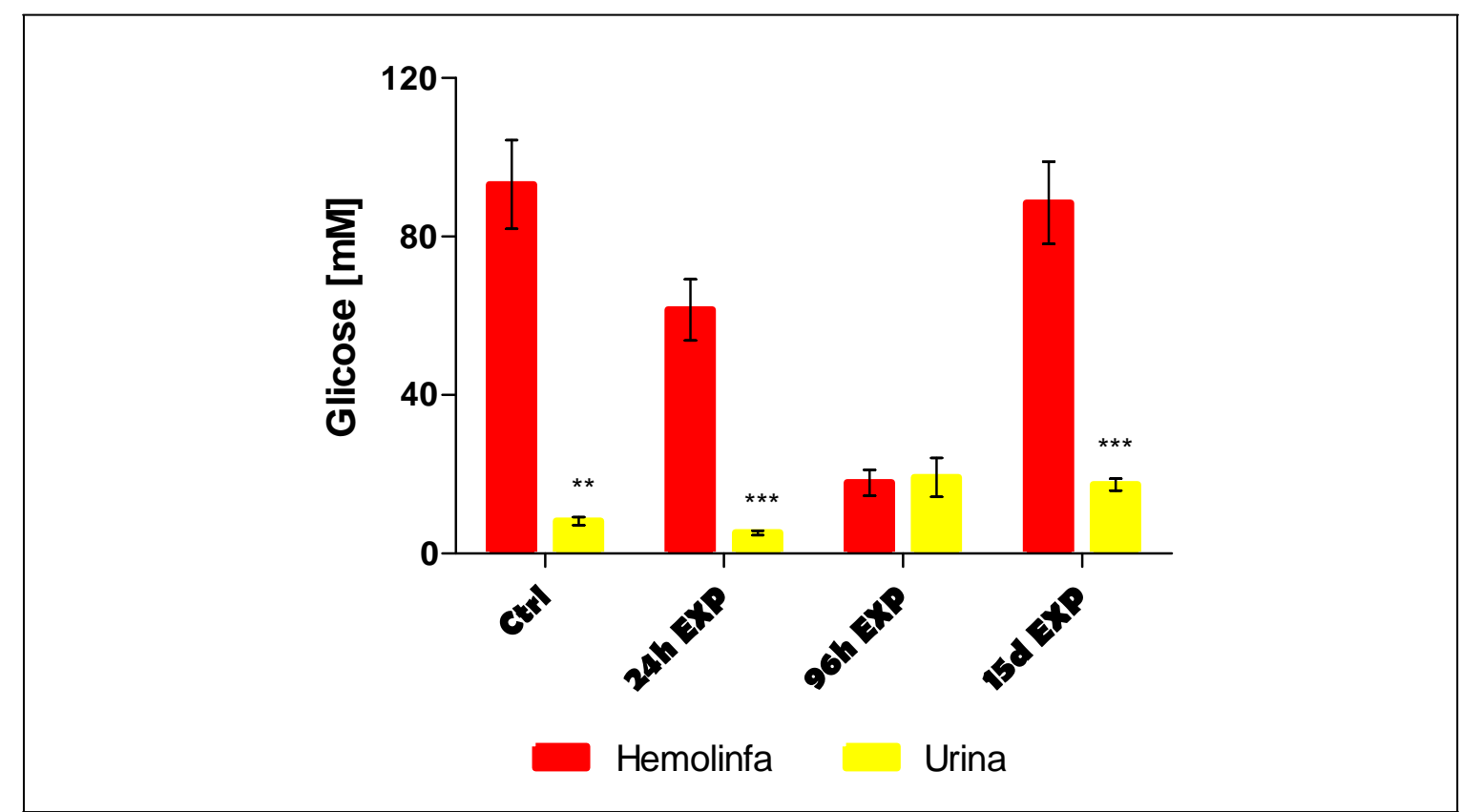

Figura 3: Comparação da concentração de glicose $(\mathrm{mM})$ em amostras de hemolinfa e urina do caranguejo de mangue Ucides cordatus submetidos a testes agudo e crônico exposição a $5 \mathrm{mg} / \mathrm{L} \mathrm{CuSO}_{4}$ na água durante (24h e $96 \mathrm{~h}$ ) e 15 dias, respectivamente, com $\mathrm{n}=10$. 
A figura 4 apresenta aumento da concentração de lactato na hemolinfa dos animais expostos durante $24 \mathrm{~h}$ e $96 \mathrm{~h}$ (teste agudo) ao cobre na água, com $\mathrm{p}<0,05$ quando comparados o grupo controle com os três grupos experimentais. É também notado nesta figura, que os valores de lactato na hemolinfa dos animais pertencentes aos grupos do teste agudo não se alteraram entre si, com $p>0,05$, porém quando comparados os grupos $24 \mathrm{~h}$ bem como o de $96 \mathrm{~h}$ com 15 dias de exposição, obteve-se $p<0,001$.

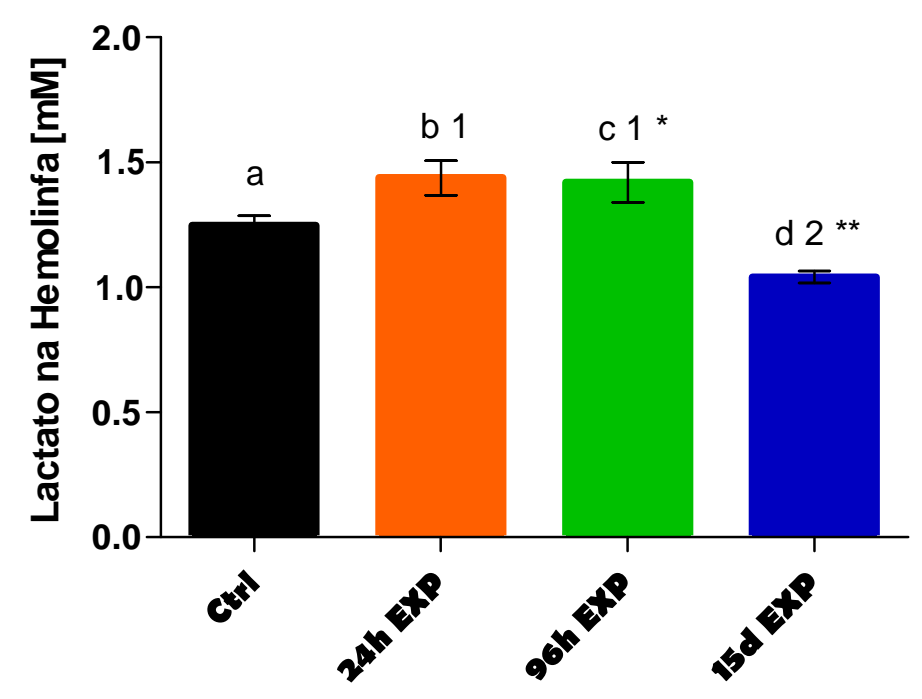

Figura 4: Determinação da concentração de lactato $(\mathrm{mM})$ em amostras de hemolinfa do caranguejo de mangue Ucides cordatus submetidos a testes agudo e crônico exposição a $5 \mathrm{mg} / \mathrm{L} \mathrm{CuSO}_{4}$ na água durante (24h e $96 \mathrm{~h}$ ) e 15 dias, respectivamente, com $\mathrm{n}=10$. 
A figura 5 apresenta aumento da concentração de lactato no grupo experimental $24 \mathrm{~h}$ com $p<0,05$ em comparação ao controle, enquanto que os grupos $96 \mathrm{~h}$ e 15 dias apresentaram redução da concentração de lactato, porém não houve diferença estatística quando comparados com o grupo controle, onde o grupo 96h atingiu valores próximos aos do controle e o grupo 15 dias apresentou redução de $11 \%$ em relação ao grupo controle.

Já quando os grupos experimentais foram comparados entre si, foi possível observar diferença estatística de $p<0,05$ para comparação entre grupos $24 \mathrm{~h}$ e 15 dias, porém quando comparados os grupos $24 \mathrm{~h}$ e $96 \mathrm{~h}$, bem como $96 \mathrm{~h}$ e 15 dias de exposição, não foi observada diferença estatística significativa, com p>0,05.

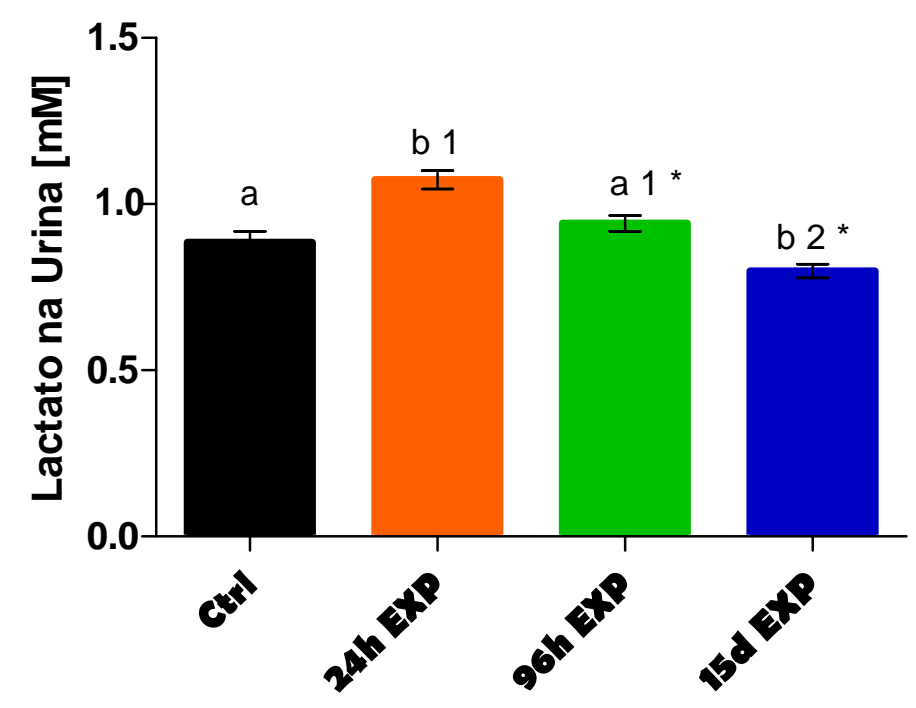

Figura 5: Determinação da concentração de lactato $(\mathrm{mM})$ em amostras de urina do caranguejo de mangue Ucides cordatus submetidos à testes agudo e crônico de exposição a $5 \mathrm{mg} / \mathrm{L} \mathrm{CuSO}_{4}$ na água durante ( $24 \mathrm{~h}$ e $96 \mathrm{~h}$ ) e 15 dias, respectivamente, com $n=10$. 
A figura 6 apresenta a comparação da concentração de lactato nos fluidos estudados, onde foi observado que em todos os grupos experimentais, bem como o grupo controle, apresentaram valores de lactato na hemolinfa superiores aos encontrados na urina, já que para todos os grupos experimentais assim como o grupo controle houve diferença estatística significativa quando comparados os valores da concentração de lactato na hemolinfa e urina, com $p<0,001$ para grupos controle e 15 dias de exposição e $p<0,01$ para os dois grupos correspondentes ao grupo agudo (24h e $96 \mathrm{~h}$ de exposição).

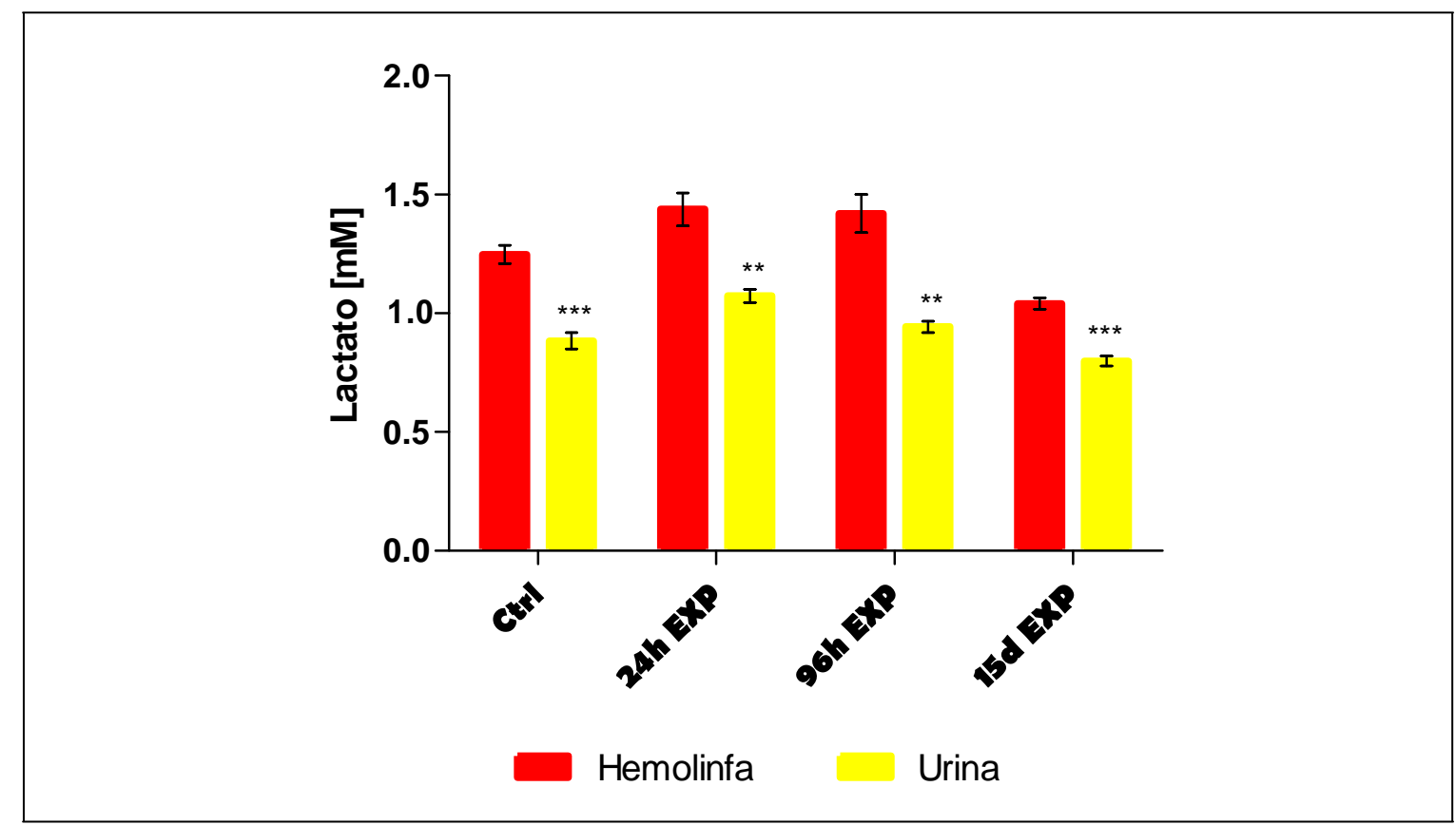

Figura 6: Determinação da concentração de lactato $(\mathrm{mM})$ em amostras de hemolinfa e urina do caranguejo de mangue Ucides cordatus submetidos à testes agudo e crônico de exposição a $5 \mathrm{mg} / \mathrm{L}$ $\mathrm{CuSO}_{4}$ na água durante (24h e $96 \mathrm{~h}$ ) e 15 dias, respectivamente, com n=10. 
A figura 7 apresenta valores de glicogênio no músculo da quela dos caranguejos de mangue expostos ao cobre na água bastante variáveis entre os grupos controle e experimentais. Quando comparados os valores de glicogênio no grupo $24 \mathrm{~h}$ de exposição ao cobre e o grupo controle, nota-se que houve um aumento das taxas de glicogênio $(p<0,05)$, porém o mesmo não foi encontrado quando comparados os valores de glicogênio dos grupos experimentais $96 \mathrm{~h}$ e 15 dias com o grupo controle $(p>0,05)$.

Mesmo com a ampla variação da concentração de glicogênio entre os grupos experimentais, foi observada diferença estatística entre grupos $24 \mathrm{~h}$ e $96 \mathrm{~h}$, bem como em comparação com o grupo exposto ao cobre na água durante 15 dias, com $p<0,001$ e $p<0,05$ (respectivamente), enquanto que a comparação entre grupos $96 \mathrm{~h}$ e 15 dias não apresentaram diferença estatística entre os valores obtidos $(p>0,05)$, mesmo sendo observado aumento do glicogênio na quela dos animais do grupo 15 dias em relação ao de $96 \mathrm{~h}$ expostos ao $\mathrm{CuSO}_{4}$ na água, sendo bastante similar aos valores encontrados para o grupo controle.

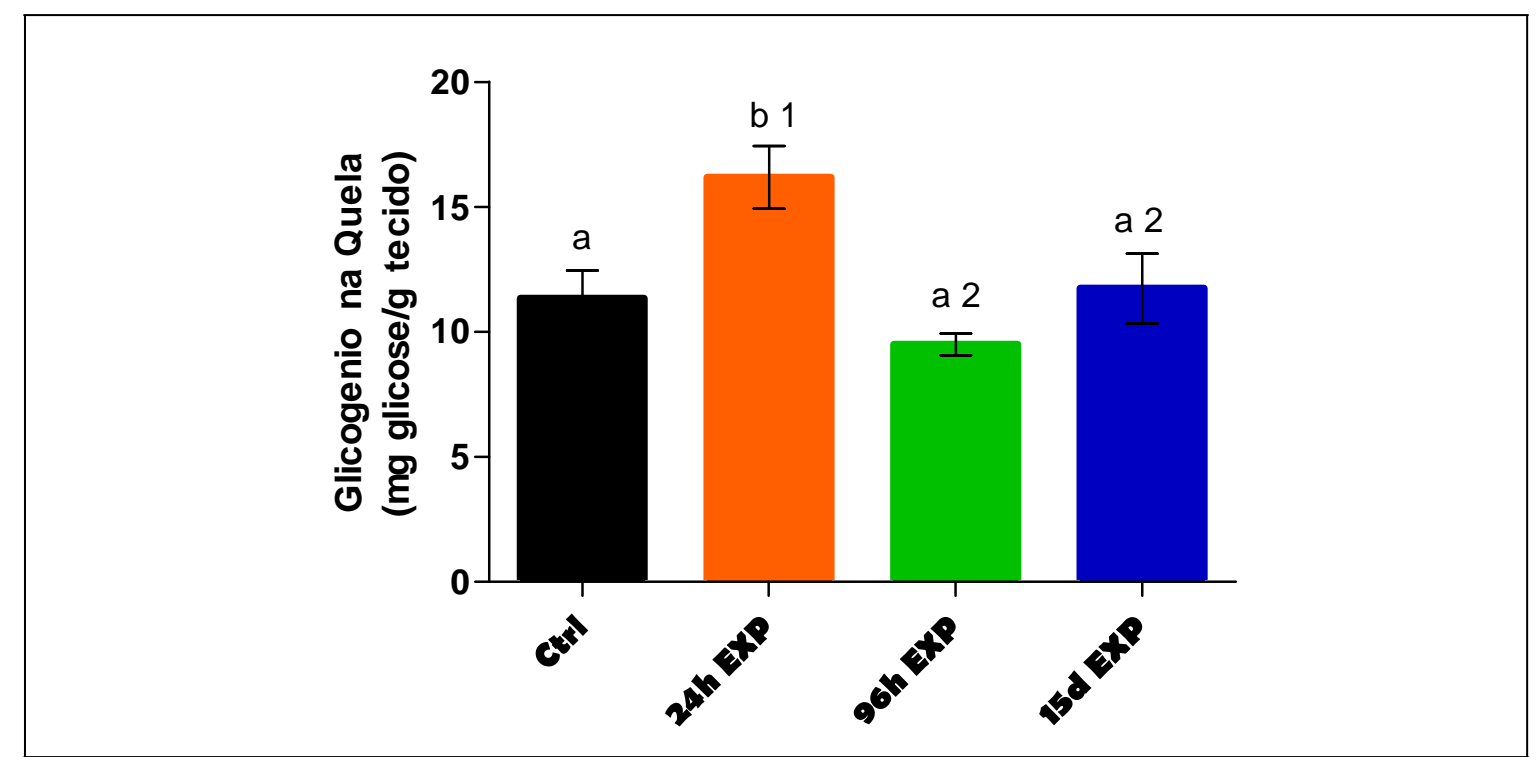

Figura 7: Determinação da quantidade de glicogênio (mg glicose/g tecido) em amostras de músculo da quela e hepatopâncreas do caranguejo de mangue Ucides cordatus submetidos à testes agudo e crônico de exposição a $5 \mathrm{mg} / \mathrm{L} \mathrm{CuSO}_{4}$ na água durante (24h e $96 \mathrm{~h}$ ) e 15 dias, respectivamente, com n=10. 
A figura 8 apresenta os valores obtidos da concentração de glicogênio no hepatopâncreas de Ucides cordatus e nota-se aumento no grupo $24 \mathrm{~h}$ experimental. Já para os valores de glicogênio dos demais grupos, houve uma redução, havendo diferença estatística entre grupos controle e 15 dias de exposição $(p<0,05)$.

Quando comparados os valores da concentração de glicogênio no hepatopâncreas do caranguejo de mangue Ucides cordatus, foi observada redução da concentração deste carboidrato nos animai submetidos à $96 \mathrm{~h}$ e 15 dias de exposição ao cobre na água, porém somente entre grupos $24 \mathrm{~h}$ e 15 dias foi encontrada diferença estatística $(p<0,05)$, enquanto que foram obtidos valore de p>0,05 para comparação entre 24h e 96h, assim como 96h e 15 dias de exposição aquática ao metal.

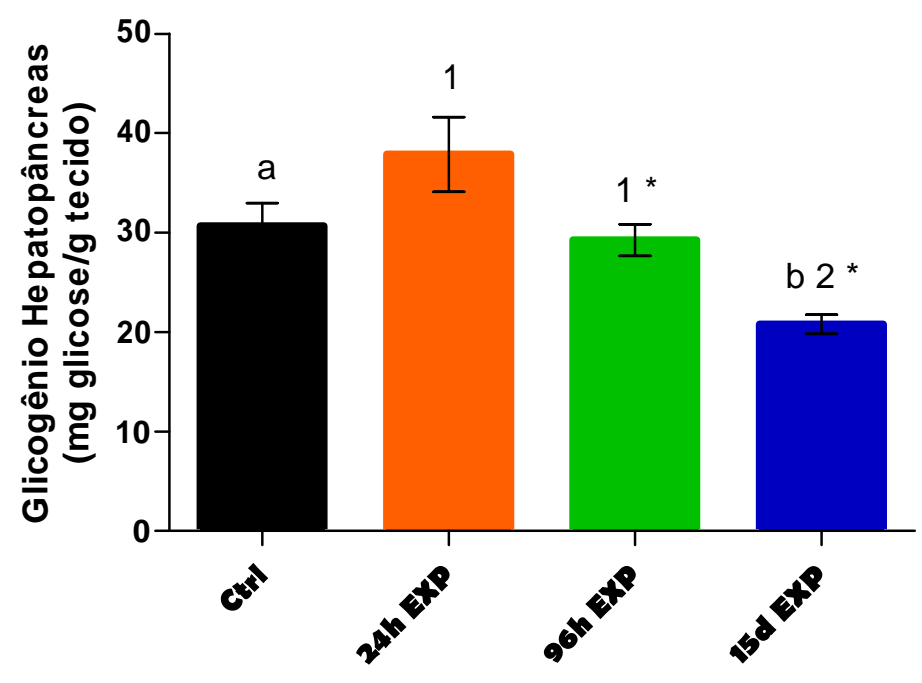

Figura 8: Determinação da quantidade de glicogênio (mg glicose/g tecido) em amostras de músculo da quela e hepatopâncreas do caranguejo de mangue Ucides cordatus submetidos à testes agudo e crônico de exposição a $5 \mathrm{mg} / \mathrm{L} \mathrm{CuSO}_{4}$ na água durante (24h e $96 \mathrm{~h}$ ) e 15 dias, respectivamente, com n=10. 
A figura 9 demonstra que, as amostras de hepatopâncreas, independentemente dos grupos analisados apresentam maiores valores de glicogênio do que o músculo da quela, com $p<0,01$ para grupo controle e $p<0,001$ para os grupos experimentais.

Mesmo sendo superiores aos valores encontrados para músculo da quela, os valores de glicogênio encontrados no hepatopâncreas do grupo exposto durante 15 dias ao cobre na água apresenta diferença de valores nominais menores do que os demais grupos.

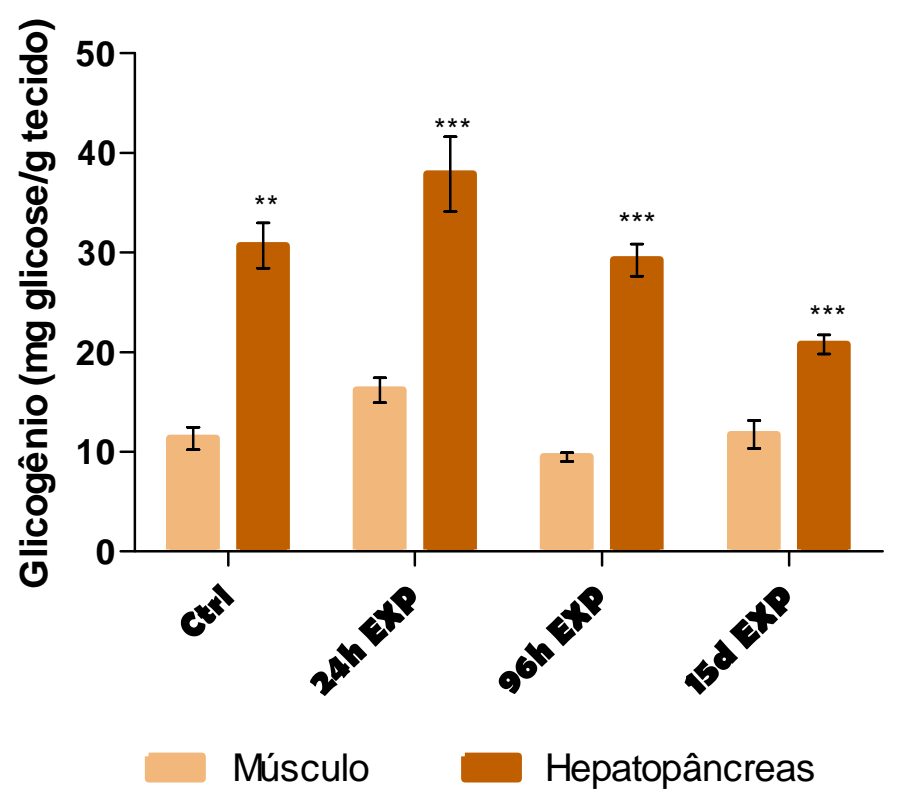

Figura 9: Determinação da quantidade de glicogênio (mg glicose/g tecido) em amostras de músculo da quela e hepatopâncreas do caranguejo de mangue Ucides cordatus submetidos à testes agudo e crônico de exposição a $5 \mathrm{mg} / \mathrm{L} \mathrm{CuSO}_{4}$ na água durante (24h e $96 \mathrm{~h}$ ) e 15 dias, respectivamente, com n=10. 


\section{DISCUSSAO}

A transição da vida aquática para a vida terrestre foi um evento que esteve presente em vários momentos da evolução, mas, frequentemente, longe de ser completo. Um grande número de invertebrados ocupa nichos ecológicos na interface água-terra e permanece capaz de se manter, ao menos temporariamente, em ambos os ambientes (TRUCHOT, 1990).

Os resultados apresentados neste capítulo demonstram os efeitos causados no metabolismo energético pela exposição aguda e crônica do caranguejo de mangue Ucides cordatus ao $\mathrm{CuSO}_{4}$ na água salobra. Observou-se que para cada produto resultante da quebra ou síntese de carboidratos há diferentes resultados obtidos. Assim, de modo geral, a glicose presente na hemolinfa apresentou maior variação de sua concentração do que na urina. Tendência similar, porém menos acentuada, também foi observada com respeito ao lactato. A concentração de glicogênio foi maior nos grupos $24 \mathrm{~h}$ e 15 dias, respectivamente, para amostras de músculo da quela e hepatopâncreas.

\section{GLICOSE}

Em crustáceos decápodas, hormônios peptídeos regulam finamente a taxa de glicemia e em particular, o $\mathrm{CHH}$ (hormônio hiperglicemiante em crustáceos) exerce uma importante função na regulação da glicemia pelo aumento dos níveis de D-glicose na hemolinfa, a partir da mobilização deste açúcar do estoque de glicogênio do hepatopâncreas e músculo. Quando os níveis de D-glicose estão baixos na hemolinfa, há liberação de $\mathrm{CHH}$, o qual induz hidrólise de glicogênio com consequente aumento da concentração de D-glicose na hemolinfa. Por outro lado, quando D-glicose está acima dos níveis normais, a liberação de CHH é inibida, revertendo o processo de produção de D-glicose em órgãos-alvo como músculo e hepatopâncreas (SANTOS \& KELLER, 1993; GLOWIK e col., 1997).

Vários são os estressores que causam a liberação de $\mathrm{CHH}$ e subsequente aumento da glicose na hemolinfa em animais intactos. O mesmo, não ocorre em indivíduos que tiveram o pedúnculo ocular retirado (LORENZON e col., 2005; ELWOOD e col., 2009). 
$\mathrm{Na}$ medida em que $\mathrm{CHH}$ é liberado frente à necessidade de aumento dos níveis glicêmicos como uma resposta adaptativa a diversos estímulos (como emersão, estivação, temperaturas críticas, entre outras), este hormônio tem sido proposto como um hormônio de estresse dos crustáceos (CHANG e col., 1999; RODRIGUEZ e col., 2007). Em razão disso, muitos pesquisadores têm examinado os efeitos dos metais ou contaminantes orgânicos na concentração de glicose no sangue dos crustáceos. Os resultados obidos até o presente sugerem que a hiperglicemia produzida por tais contaminantes se deve amplamente à liberação de quantidades excessivas de CHH (hormônio hiperglicemiante) (FINGERMAN e col., 1998).

O CHH é o neuropeptídeo mais bem conhecido dos crustáceos e suas funções são: manter e controlar os níveis de glicose no sangue, controlar a secreção de amilase e um possível papel na regulação da síntese de ecdisteróides e osmorregulação. O CHH promove uma hiperglicemia, a qual é mantida por algumas horas durante situações de estresse, como emersão, anóxia, variações da salinidade e mudanças de temperatura. Além do $\mathrm{CHH}$ em si, WEBSTER (1996) também analisou um possível mecanismo de feedback (negativo e positivo), sobre a liberação de $\mathrm{CHH}$ no sangue do caranguejo através da ação da glicose e lactato, apresentando resultados que evidenciam claramente alterações metabólicas promovidas por uma situação de estresse, no caso específico, a emersão. Foi observada uma rápida hiperglicemia nesses animais assim como um rápido aumento de lactato, sendo observado também um aumento considerável dos níveis de $\mathrm{CHH}$ no sangue do animal. Durante a emersão o suprimento de oxigênio desses animais fica comprometido e, desta forma, os animais fazem uso do metabolismo anaeróbio, com produção de lactato, o qual, como foi analisado no estudo de WEBSTER supracitado, promove a liberação de $\mathrm{CHH}$ na hemolinfa dos crustáceos.

LORENZON e col. (2000) encontraram que diversos meais, incluindo mercúrio, cádmio e cobre induzem hiperglicemia no camarão Palaemon elegans. Como uma tendência geral, foi encontrada resposta hiperglicemiante, mas esta é dependente do metal utilizado, sua concentração e tempo de exposição. Os metais citados acima causaram hiperglicemia em baixas concentrações (RODRIGUEZ e col., 2007) e é possível que tais contaminantes atuem diretamente nos carboidratos presentes nos músculos e também hepatopâncreas, sendo ambos tecidos-alvo de CHH (SEDLMEIER, 1985), liberando glicose quando afetados pelo hormônio hiperglicemiante (FINGERMAN e col., 1998).

REDDY e col., 1994 verificaram que a exposição ao (cloreto de cádmio) $\mathrm{CdCl}_{2}$ causou hiperglicemia no lagostim Procambarus clarkii, durante $72 \mathrm{~h}$ de exposição, e tal resultado 
também foi encontrado em Macrobrachium kistnensis e no caranguejo Barytelphusa cunicularis, nos quais tal hiperglicemia pode ser induzida e/ou mediada por algum outro fator, além de ser completamente dependente do $\mathrm{CHH}$ (hormônio hiperglicemiante).

A hiperglicemia causada pela indução da liberação de $\mathrm{CHH}$ foi observada em Cancer pagurus (WEBSTER, 1996) e na lagosta Homarus americanus (CHANG e col., 1998). A exposição do camarão Palaemon elegans ao cobre tem efeito similar (ELWOOD e col., 2009) após imersão e subsequente hipóxia, indicando que em situação de estresse o metabolismo é acelerado de forma a suprir as necessidades do organismo e, para isso, é necessária uma grande quantidade de energia.

Os resultados de glicose na hemolinfa, obtidos no presente estudo, corroboram os dados da literatura, indicando que Ucides cordatus, em situação de estresse, mobilizou glicose a partir da quebra do glicogênio, e a liberação do excesso de glicose presente na hemolinfa para a urina demonstra que o hormônio $\mathrm{CHH}$ não foi inibido na presença de metal, como tem sido sugerido por alguns autores. Talvez, sejam necessárias maiores concentrações de metal para exercer a inibição da secreção do $\mathrm{CHH}$ nos pedúnculos oculares, ou seja, inibição das enzimas envolvidas na síntese deste hormônio. Tal aumento da glicose no sangue pode ser resultado da redução dos níveis deste açúcar no hepatopâncreas e músculos, e a redução dos níveis de glicose pode estar relacionada com a perda ou danificação do pedúnculo ocular, que atua como sítio de fonte e liberação de $\mathrm{CHH}$. Normalmente, a ablação do pedúnculo, ou somente a ablação da glândula do sítio resulta em hipoglicemia (REDDY e col., 1994).

O aumento dos níveis de glicose na hemolinfa sugere que a glicose em excesso é mobilizada a partir dos tecidos e passa a ser utilizada na cadeia glicolítica, levando a um acúmulo de glicose circulante (MACIEL e col., 2008), a qual, por sua vez, pode apresentar-se como substrato para o metabolismo oxidativo nos crustáceos (HU, 1958; WEBER, 1971). No entanto, caranguejos Ucides cordatus, expostos a concentrações de 0,02 a 0,2 mM de cromo, apresentaram uma hipoglicemia, enquanto que aqueles expostos a manganês apresentaram uma hiperglicemia e logo em seguida uma branda hipoglicemia. Tal redução da glicemia pode estar ligada à inibição que o metal exerce nas enzimas envolvidas na síntese de CHH (WEBER, 1971).

O hormônio hiperglicemiante dos crustáceos $(\mathrm{CHH})$ possui, em geral, efeitos similares aos do cortisol ou da corticosterona. O principal efeito é a elevação dos níveis de glicose na hemolinfa e dos níveis de lactato, por meio da mobilização de estoques intracelulares de 
glicogênio, onde a mobilização destes estoques intracelulares pode ser utilizada como um indicador de estresse (STENTIFORD e col., 2001; ELWOOD e col., 2009).

\section{LACTATO}

O lactato, produto final da glicólise anaeróbica, pode ser utilizado como indicador do estado de oxigenação em tecidos. Níveis elevados de lactato no sangue ocorrem em anóxia devido ao choque, parada cardíaca congestiva, intoxicação e deficiência de tiaminas.

O lactato controla positivamente a liberação de hormônio hiperglicêmico $(\mathrm{CHH})$ dos crustáceos, o qual promove o aumento da concentração de glicose na hemolinfa. Esta glicose é utilizada pelo ciclo glicolítico para originar ATP. Em Chasmagnathus granulatus, uma redução do oxigênio na água leva à ativação da cadeia glicolítica no músculo e hepatopâncreas. Durante a hipóxia, a regulação do equilíbrio ácido-base via utilização de altos níveis de lactato, na gliconeogênese, pode ser favorável a ajustes metabólicos, em Chasmagnathus granulatus, com o eficiente uso do ATP produzido (MACIEL e col., 2008).

O estudo feito por MACIEL e col. (2008) mostrou a produção de lactato tanto em indivíduos em anóxia/hipóxia quanto em indivíduos em normóxia, e demonstrou que o lactato, mesmo em normóxia, pode ser utilizado em duas rotas: (i) oxidação para dióxido de carbono via ciclo do ácido tricarboxílico e (ii) conversão para glicose via glicogênese no músculo da mandíbula. PHILIP e col. (2005), por outro lado, sugerem que o lactato seja um metabólito ativo, movendo-se entre as células, tecidos e órgãos, onde pode ser oxidado como substrato energético ou reconvertido para piruvato ou glicose.

Como citado na literatura, o aumento do lactato indica a redução da mobilização do piruvato para o ciclo de Krebs. Entretanto, isso não foi observado no presente estudo para os valores encontrados na hemolinfa, sugerindo que o ciclo do ácido cítrico possa ainda nãoter sido prejudicado pela ação do metal na água (talvez não na concentração do metal utilizada), muito embora o aumento das concentrações de lactato em situações de anóxia e hipóxia tem sido observado em outros crustáceos, e o lactato é considerado como sendo o principal produto final da anaerobiose nesta classe de invertebrados (MACIEL e col., 2008).

Como ocorre interferência do cobre no ciclo do ácido cítrico, e consequente redução da mobilização do piruvato para este ciclo, as alterações observadas para a concentração de lactato pode indicar que o animal esteja sofrendo hipóxia ou anóxia, mesmo havendo 
suprimento de oxigênio a partir de aeradores durante todo o experimento realizado, o que pode sugerir que as brânquias poderiam, dessa maneira, responder ao estresse ao qual o animal foi submetido, reduzindo a captação de oxigênio.

O aumento da excreção de lactato na água, observado no presente estudo, provavelmente visa auxiliar o controle da concentração de lactato circulante. A eliminação direta de lactato no meio aquático tem sido observada em diversas espécies de crustáceos (MACIEL e col., 2008). Embora a razão para o aumento da excreção de lactato durante a hipóxia requeira mais investigações para Chasmagnathus granulatus (como citado por MACIEL e col., 2008), uma hipótese tem sido sugerida de que pode ser um mecanismo de compensação devido à redução da taxa de oxidação do lactato no músculo de caranguejos em hipóxia, apesar do efeito positivo do ânion lactato na afinidade do oxigênio pela hemocianina encontrada em outras espécies de caranguejos, e do aumento da síntese de glicose proveniente do lactato (MACIEL e col., 2008). A excreção de lactato no meio aquático é outro caminho utilizado pelos caranguejos sob condições de oxigenação adequada (MACIEL e col., 2008).

O aumento de lactato na hemolinfa muito rápido, logo antes da morte, pode ser devido a níveis letais de cobre, indicando que o animal intoxicado se asfixiou, provavelmente devido à acentuada redução da capacidade de difusão de oxigênio das brânquias (BOITEL \& TRUCHOT, 1989; NONNOTTE e col., 1993; SPICER \& WEBER, 1992; RTAL \& TRUCHOT, 1996).

\section{GLICOGÊNIO}

Como o glicogênio é o principal polissacarídeo de armazenamento nas células animais, além de ser a substância de reserva mais adequada, a determinação de sua concentração em hepatopâncreas e músculo da quela é importante para, assim como no caso da glicose, verificar se o estresse causado pelo metal na água afeta os mecanismos de reserva de energia.

O aumento significativo do glicogênio só pode ser devido ao aumento da atividade de enzimas relacionadas com a glicogênese e tal aumento pode, talvez, ser devido à indução enzimática por cátions específicos, ou através do sistema endócrino (SRIVASTAVA, 1982). A redução da enzima piruvato desidrogenase leva à redução da atividade de enzimas glicolíticas em vertebrados, com o concomitante aumento na gliconeogênese (VOSLOO e col., 2002). O aumento dos níveis de glicogênio nos tecidos indica aceleração da rota de gliconeogênese e não da rota glicolítica (VOSLOO e col., 2002). 
Quando o nível de açúcar no sangue cai, as células do fígado degradam glicogênio e as subunidades de glicose liberadas entram na corrente sanguínea (STARR e col., 2011). O aumento dos níveis de glicogênio nos rins de animais expostos ao cádmio e cobre aparenta ser devido ao seu envolvimento na reabsorção de glicose. O cádmio aparenta causar hiperglicemia e depleção de glicogênio, prejudicando a formação de insulina e o mesmo ocorre com o cobre (SRIVASTAVA, 1982).

Já a exposição do lagostim Procambarus clarkii a cádmio não causou efeito na concentração de glicogênio de hepatopâncreas e músculos, embora a concentração de glicose tenha diminuído nestes tecidos (TORREBLANCA e col., 1992). Da mesma maneira, mercúrio não causou efeito significativo na concentração de glicogênio no hepatopâncreas deste lagostim, e vale ressaltar que valores de glicose não foram medidos (TORREBLANCA e col., 1991). Porém, por outro lado, os valores de glicogênio no músculo e hepatopâncreas do lagostim Orconectes limosus diminuíram após injeção de CHH (KELLER \& ANDREW, 1973; SEDLMEIER \& KELLER, 1981). A depleção do glicogênio pode ser devido à aceleração da glicogenólise como resposta às mudanças (alterações) nos tecidos causadas por redução de pH ou hipóxia, resultando em acidose (SRIVASTAVA, 1982).

Os grupos experimentais de $96 \mathrm{~h}$ e 15 dias de exposição ao cobre na água apresentaram redução das taxas de glicogênio, indicando que, por estarem submetidos a uma situação de estresse, houve um maior consumo de glicogênio, que pode ser rapidamente catabolizado, resultando na perda dos tecidos de reserva, sendo neste caso músculo da quela e hepatopâncreas.

Além do fato de que há consumo de glicogênio no caranguejo de mangue Ucides cordatus, a redução de suas taxas de glicogênio, tanto nas amostras de músculo da quela quanto de hepatopâncreas, pode-se sugerir que tais alterações podem ter ocorrido em decorrência de uma situação de estresse adicional, uma hipóxia ou anóxia promovida pela adição de sulfato de cobre $\left(\mathrm{CuSO}_{4}\right)$ na água, aumentando, consequentemente, o consumo de glicogênio, mesmo que o suprimento de oxigênio, durante todos os experimentos, tenha permitido a manutenção de uma situação de normóxia. 


\section{CONCLUSAO}

Como os metais - independentes de serem ou não essenciais - estão entre os principais poluentes, quando incluídos no ambiente de forma antropogênica em altas concentrações, eles podem causar efeitos no metabolismo energético dos mais diversos organismos, alterando assim ciclos e cascatas de eventos cuja importância é essencial, como revelaram os resultados obtidos no presente estudo, após análise da concentração de glicose e lactato, na hemolinfa e urina, e de glicogênio, no hepatopâncreas e músculo da quela de Ucides cordatus.

Tais efeitos são bastante distintos, dependendo das variáveis analisadas, e se alteram de acordo com o tempo de exposição. Por isso, não se deve analisar somente um ou outro produto resultante das quebras e síntese de carboidratos. As análises de efeitos toxicológicos devem ser feitas de maneira conjunta a fim de haver uma correta e completa interpretação dos fatos.

Com base nessas ponderações, é possível concluir que:

- Caranguejos de mangue Ucides cordatus expostos durante $24 \mathrm{~h}$ e $96 \mathrm{~h}$ ao cobre na água apresentaram redução dos níveis de glicose inferiores aos do grupo controle, enquanto que animais expostos durante 15 dias demonstram valores similares ao grupo controle. Ao contrário do que foi observado na hemolinfa de Ucides cordatus, a urina dos animais expostos durante $96 \mathrm{~h}$ ao cobre na água apresentou aumento da concentração deste açúcar;

- Os valores de lactato na hemolinfa dos caranguejos, em relação ao grupo controle, são superiores nos grupos de teste agudo e inferiores no grupo do teste crônico (15 dias de exposição). Porém, quando os valores da concentração de lactato na urina destes animais são analisados, observa-se um aumento da concentração deste produto do metabolismo apenas no grupo exposto durante $24 \mathrm{~h}$ à água contaminada com cobre;

- Na comparação dos valores de glicogênio encontrados em amostras do músculo da quela destes caranguejos, foi possível observar que houve aumento dos níveis deste carboidrato somente no grupo exposto durante $24 \mathrm{~h}$, enquanto que, nas amostras de hepatopâncreas analisadas, o grupo exposto durante 15 dias ao cobre na água foi aquele que apresentou uma redução do glicogênio. 
Capítulo 4 - Efeitos do cobre no estresse oxidativo do caranguejo de mangue Ucides cordatus 


\section{RESUMO}

Dezenas de cuproenzimas são conhecidas e a sua disfunção pode ser fatal para alguns organismos. Existe uma grande variedade de proteínas transportadoras de íons específicos e dentre estas duas enzimas exercem função central na osmorregulação, a $\mathrm{Na}^{+} / \mathrm{K}^{+}-\mathrm{ATPase}$ e aanidrase carbônica. Os gradientes de concentração de sódio e potássio existentes através das membranas celulares são mantidos pela atividade de uma bomba que requer energia para transportar sódio para fora da célula em troca do potássio. A anidrase carbônica, a qual se encontra associada à membrana basal e catalisa a hidratação reversível de $\mathrm{CO}_{2}$ e água em $\mathrm{H}^{+} \mathrm{e}$ $\mathrm{HCO}_{3}{ }^{-}$, está envolvida em diversas funções fisiológicas, tais como respiração, transporte iônico, regulação ácido-base, osmorregulação e calcificação. As metalotioneínas são encontradas na maioria dos taxa zoológicos. São moléculas solúveis, estáveis, com baixo peso molecular (6 800 daltons), ricas em sulfidril e particularmente ricas em cisteína (20-30\%). Os caranguejos de mangue Ucides cordatus foram expostos durante $24 \mathrm{~h}$, $96 \mathrm{~h}$ e 15 dias a $5 \mathrm{mg} / \mathrm{L} \mathrm{CuSO}_{4}$ na água para a determinação das atividades das enzimas $\mathrm{Na}^{+} / \mathrm{K}^{+}$-ATPase e anidrase carbônica, assim como a concentração de metalotioneína, em alíquotas de brânquias anteriores, brânquias posteriores e hepatopâncreas. Foi possível identificar que a atividade da $\mathrm{Na}^{+} / \mathrm{K}^{+}$-ATPase é distinta nas brânquias anteriores e posteriores. A atividade da $\mathrm{Na}^{+} / \mathrm{K}^{+}-\mathrm{ATPase}$ foi mais elevada nas brânquias anteriores em função do tempo de exposição, enquanto que nas brânquias posteriores houve redução da atividade enzimática ao longo do tempo de exposição, indicando que estas brânquias possuem uma função predominantemente osmorregulatória. No hepatopâncreas, os resultados indicam que a atividade da $\mathrm{Na}^{+} / \mathrm{K}^{+}$-ATPase não é dependente do tempo de exposição, sugerindo que algum mecanismo de proteção contra o poluente possa ter sido estimulado, o qual permitiria que houvesse uma aclimatação ao ambiente poluído. A atividade da anidrase carbônica foi afetada pela exposição ao cobre e os resultados sugerem que o aumento da atividade da enzima esteja relacionado com o incremento dos processos iono e osmorregulatórios. A concentração de metalotioneína foi bastante similar nas brânquias anteriores, nas brânquias posteriores e no hepatopâncreas, embora nas brânquias anteriores tenha ocorrido uma dependência da concentração em função do tempo de exposição, enquanto que no hepatopâncreas pode ter havido uma regulação da concentração de cobre e, consequentemente, uma indução da proteína quelante de cobre, a metalotioneína.

Palavras - chave: anidrase carbônica, cobre, metalotioneína, $\mathrm{Na}^{+} / \mathrm{K}^{+}$-ATPase, Ucides cordatus. 


\section{ABSTRACT}

Several copper enzymes are known and their dysfunction can be fatal to some organisms. Regardless of the variety of proteins which transport specific ions, two enzymes appear to exert a central role in osmoregulation, i.e. the $\mathrm{Na}^{+} / \mathrm{K}^{+}$-ATPase and carbonic anhydrase. The sodium and potassium concentration gradients existing across cell membranes are maintained by the activity of a pump which requires energy to carry out the exchanges of sodium and potassium in an out of the cells. The carbonic anhydrase which is associated to the cell membrane and catalyzes the reversible hydration of $\mathrm{CO}_{2}$ and water into $\mathrm{H}^{+}$and $\mathrm{HCO}_{3}$ is involved in various physiological functions such as breathing, ion transport, acid-base regulation, osmoregulation and calcification. Metallothioneins are found in most animal taxa and are soluble, stable, low molecular weight (6-800 daltons) and sulfhydryl-rich molecules, particularly rich in cysteine (20-30\%). Mangrove crabs Ucides cordatus were exposed to $5 \mathrm{mg} / \mathrm{L}$ $\mathrm{CuSO}_{4}$ in water for 24,96 and 15 days. The $\mathrm{Na}^{+} / \mathrm{K}^{+}$-ATPase and carbonic anhydrase activities, and the concentration of metallothionein in aliquots of anterior and posterior gills and hepatopancreas were determined. The activity of the $\mathrm{Na}^{+} / \mathrm{K}^{+}$-ATPase was distinct in the anterior and posterior gills. The activity in the anterior gills increased as a function of exposure time, whereas the posterior gills showed a reduced enzyme activity over time, indicating that these gills possess a predominantly osmoregulatory role. With regards to the hepatopancreas, the results indicate that the $\mathrm{Na}^{+} / \mathrm{K}^{+}$-ATPase activity was not dependent on exposure time, suggesting the existence of a protective mechanism against the pollutant, which may have allowed the subjects to acclimate to the polluted environment. The carbonic anhydrase activity was affected by exposure to copper in a direct way, and the results indicate that the increased activity of the enzyme is related to increments of the osmoregulatory and ionoregulatory processes. The concentration of the metallothionein was very similar in both anterior and posterior gills as well as in hepatopancreas. The gills, however, showed a dependence on exposure time, whereas in the hepatopancreas a regulation of the copper concentration might have occurred, suggesting that the copper chelating protein, metallothionein, was induced.

Keywords: carbonic anhydrase, copper, metallothioneins, Na/K-ATPase, Ucides cordatus. 


\section{INTRODUÇAO}

As respostas químicas, físicas e biológicas do ambiente ao estresse podem alterar certas funções biológicas e contribuir para a indução de doenças ou até mesmo de morte em alguns animais. Há algum tempo que a contaminação por metal de ambientes aquáticos tem atraído significativa atenção. Muitos processos industriais e aqueles relacionados à agricultura têm contribuído para a contaminação de sistemas aquáticos, causando efeitos adversos ao ambiente e à saúde de seres humanos (LI e col., 2008).

O cobre é um elemento cofator em uma gama muito grande de reações bioquímicas denominadas redox, as quais envolvem enzimas/proteínas intracelulares, como a citocromo c oxidase, superóxido dismutase, dopamina-hidroxilase, lisiloxidase e ceruloplasmina extracelular. A natureza redox do cobre que o faz essencial para processos como respiração celular, defesa de radicais livres e metabolismo celular do ferro, faz deste metal um agente tóxico em potencial (GROSELL e col., 2004; BOSSUYT \& JANSSEN, 2005; FOSSET e col., 2005).

Nos mamíferos, são conhecidas dezenas de cuproenzimas e a disfunção de algumas delas pode ser fatal para algumas espécies. Portanto, a homeostase do cobre é necessária, mesmo sob condições de deficiência deste metal (OGRA e col., 2006). A Na ${ }^{+} / \mathrm{K}^{+}-$ATPase e a anidrase carbônica, dentre uma grande variedade das proteínas de transporte para íons específicos, exercem papel central na osmorregulação (SKAGGS \& HENRY, 2002; TSAI \& LIN, 2007).

Elementos tóxicos causam alterações nas organelas celulares, podendo induzir aumento ou inibição da atividade de diferentes enzimas antioxidantes (SABATINI e col., 2009). A indução de enzimas de defesa antioxidante pode desencadear processos relacionados às condições de estresse oxidativo, já que tais enzimas executam funções cruciais na manutenção da homeostase celular (BORKOVIĆ e col., 2008). 


\section{$\mathrm{Na}^{+} / \mathrm{K}^{+}$-ATPase}

Os gradientes elevados de concentração de sódio e potássio existentes através das membranas celulares são mantidos pela atividade de uma bomba que requer energia para transportar sódio para fora da célula em troca do potássio. A energia para o bombeamento é fornecida pelo ATP gerado durante as reações metabólicas celulares, onde três íons sódio são bombeados para fora e dois íons potássio para dentro da célula, para cada molécula de ATP hidrolisada à ADP (adenosina trifosfato) e fosfato inorgânico (SCHIMIDT-NIELSEN, 2002).

Em animais hiperosmorreguladores, as brânquias constituem uma interface seletiva, a qual absorve ativamente íons sódio e cloreto do meio externo diluído e a $\mathrm{Na}^{+} / \mathrm{K}^{+}$-ATPase é a molécula chave para este processo (MASUI e col., 2003). A atividade da $\mathrm{Na}^{+} / \mathrm{K}^{+}$-ATPase parece estar ligada à captação pelos tecidos de uma variedade de solutos. Para tal, moléculas transportadoras facilitam o co-transporte específico e compulsório do sódio e da molécula do soluto considerado para cada situação (SCHIMIDT-NIELSEN, 2002).

A Na ${ }^{+} / \mathrm{K}^{+}$-ATPase é membro de uma família de P-ATPases que transforma a energia química do ATP para o transporte iônico, gerando um gradiente eletroquímico de sódio e potássio através das membranas celulares (GEERING, 2000; JORGENSEN \& PEDERSEN, 2001). A enzima consiste numa cadeia $\alpha$ contendo um sítio de ligação de ATP, um sítio de fosforilação e ligação de resíduos e aminoácidos e uma cadeia $\beta$ que atua como chaperona molecular para o correto empacotamento da cadeia $\alpha$, quando necessário (MASUI e col., 2003).

A Na $/ \mathrm{K}^{+}$-ATPase, ou apenas bomba de sódio, possui função essencial nos processos de demanda de energia, nas brânquias. Esta bomba foi primeiramente identificada em homogeneizado de tecido nervoso de Carcinus maenas por SKOU, em 1960, quando este descreveu a atividade de hidrólise de ATP, dependente da presença simultânea de sódio e potássio (LUCU \& TOWLE, 2003). A Na ${ }^{+} / \mathrm{K}^{+}$-ATPase se encontra posicionada para bombear íons sódio do citosol, através da membrana basolateral, para o fluido extracelular, em troca de íons potássio, que se movem na direção oposta (LUCU \& TOWLE, 2003).

A $\mathrm{Na}^{+} / \mathrm{K}^{+}$-ATPase é responsável pelo transporte iônico nas brânquias nos peixes de água doce e de água salgada, e com base na função desta bomba, podemos esperar que ela atue de modo similar com respeito ao acúmulo de metais nesses dois ambientes. No entanto, estudos recentes, realizados com brânquias de peixes eurialinos, demonstraram que diferentes isoformas são expressas em resposta a diferentes salinidades e que diferentes 
isoformas podem exibir sensibilidades diversas ao cobre (GROSELL e col., 2004). Mesmo se considerarmos a existência de diferentes isoformas de $\mathrm{Na}^{+} / \mathrm{K}^{+}$-ATPase em diferentes espécies, tanto de vertebrados como de invertebrados, a homologia dessas macromoléculas não é inferior à $70 \%$, indicando que se tratam de moléculas altamente conservadas durante o curso da evolução (LUCU e col., 2000).

\section{ANIDRASE CARBÔNICA}

A anidrase carbônica é uma enzima envolvida em diversas funções como a respiração, o transporte iônico, a regulação ácido-base, a osmorregulação (COSTLOW, 1959; HENRY \& KORMANIK, 1985; HENRY, 1988; BOTTCHER e col., 1991; VITALE e col., 1999), através da catalização da hidratação reversível de $\mathrm{CO}_{2}$ e água em hidrogênio e bicarbonato (SKAGGS \& HENRY, 2002; VITALE e col., 1999) e utiliza o cobre e outros metais como cofator (VITALE e col., 1999).

À medida que $\mathrm{o} \mathrm{CO}_{2}$ atravessa a parede do capilar tecidual e entra no sangue, a presença de anidrase carbônica permite a formação instantânea de ácido carbônico que, por sua vez, interfere de modo imediato na dissociação da oxihemoglobina sensível ao ácido. Esta sensibilidade ao ácido, o efeito Bohr, obviamente não ocorreria a tempo enquanto o sangue permanecesse no capilar sanguíneo, a menos que a hidratação da molécula de $\mathrm{CO}_{2}$ fosse acelerada pela enzima. Portanto, a ausência de anidrase carbônica, o efeito Bohr não seria de muita importância. Além disso, a atividade da anidrase carbônica aparenta ser necessária para a sobrevivência de crustáceos eurialinos à mudança/transferência da água do mar para a água que é tipicamente encontrada em habitat estuarino (SKAGGS \& HENRY, 2002).

A presença universal da anidrase carbônica no tecido branquial de todas as espécies estudadas até o presente confere a esta enzima um papel crítico nas funções osmorregulatórias das brânquias de invertebrados aquáticos (SKAGGS \& HENRY, 2002).

A especificidade da anidrase carbônica é alta nas brânquias de invertebrados, mas tal condição é também observada em muitos outros tecidos, como músculo, coração, gônadas masculinas, hipoderme e glândula digestiva, e até mesmo na hemolinfa. Porém, neste fluido a sua atividade é bem menor e em determinados casos é quase inexistente (VITALE e col., 1999).

Como a inibição da enzima no animal vivo não lhe causa grandes dificuldades, a enzima é, provavelmente, importante principalmente sob condições de extrema demanda 
junto ao mecanismo de transporte de gases, já que possui grande importância na liberação de oxigênio nos tecidos, bem como no transporte de gás carbônico (SCHIMIDT-NIELSEN, 2002).

\section{METALOTIONEÍNA}

Diversos estudos têm demonstrado que as metalotioneínas são amplamente distribuídas, ocorrendo em procariontes, protistas, fungos, plantas e animais (KAGI \& KOJIMA, 1987; ROESIJADI, 1992). Primeiramente descritas em mamíferos no final dos anos 1950, as metalotioneínas têm sido estudadas em diversos invertebrados aquáticos, especialmente moluscos e crustáceos (MONSERRAT e col., 2006). Estas proteínas exercem função primária na homeostase de metais essenciais como cobre e zinco, e estão envolvidas na detoxificação de metais não essenciais, particularmente cádmio (ROESIJADI, 1992; AMIARD \& COSSON, 1997; LEGRAS e col., 2000).

Já para as espécies aquáticas, as metalotioneínas foram primeiramente reportadas para o peixe marinho Scyliorhinus bastes seboides e tal resultado foi seguido por demonstrações da presença de metalotioneína em outras espécies de peixes marinhos, para o molusco marinho Crassostrea virginica e para o mexilhão Mytilus edulis (ROESIJADI, 1992).

A destoxificação de da grande maioria dos metal é feita através da síntese de metalotioneína (6 -10 KDa) (HEBEL e col., 1997) tipicamente pela ligação com grânulos inorgânicos de alta afinidade como a metalotioneína ou ferritina, frequentemente contendo uma base fosfato, (HEBEL e col., 1997; RAINBOW, 2000).

As metalotioneínas fazem parte de uma classe de proteínas não enzimáticas e são encontradas na maioria dos taxa zoológicos (ROESIJADI, 1992) e apresentam as seguintes características: são solúveis e estáveis, possuem baixo peso molecular (6-800 KDa), são ricas em sulfidril e particularmente ricas em cisteína (20-30\%) (ROESIJADI, 1992), não possuem aminoácidos aromáticos e são estáveis sob calor (VIARENGO \& NOTT, 1993; MONSERRAT e col., 2006). O grupo tiol (-SH) de resíduos de cisteína capacita as metalotioneínas a se ligar a metais pesados específicos (GROSELL \& WOOD, 2002).

Geralmente, a concentração de metalotioneína em organismos aquáticos é baixa. No entanto, quando os organismos são expostos a elevados níveis de metais, proteínas de baixo peso molecular e peptídeos (ex. metalotioneína ou fitoqueltina) são induzidos a se ligar aos 
metais, contrapondo-se assim ao efeito tóxico destes (YANG e col., 2007) já que tais moléculas estão também envolvidas na homeostase, armazenamento, transporte e metabolismo de metais essenciais, como zinco e cobre (BOSSUYT \& JANSSEN, 2005). De fato, o aumento da concentração de metais nas células estimula a síntese "de novo" de apotioneínas, as quais podem se ligar a cátions de metais sob forma não tóxica, reduzindo deste modo os seus efeitos deletérios (VIARENGO e col., 1997; MONSERRAT e col., 2006).

Os órgãos nos quais as metalotioneínas são concentradas nos animais aquáticos são fígado (ou órgão equivalente em invertebrados), rins, brânquias e intestinos (ROESIJADI, 1992). Estes órgãos se encontram diretamente envolvidos na tomada de metais, estoque e excreção, e apresentam alta capacidade de síntese de metalotioneína (AMIARD e col., 2006).

Muitos estudos ressaltam o papel da metalotioneína como um biomarcador específico de exposição a metais, já que a elevação da sua concentração está diretamente relacionada à exposição ao poluente (ROESIJADI, 1992; PEDERSON e col., 1997; WU \& CHENG, 2005). No entanto, fatores naturais e fisiológicos devem ser levados em conta (PEDERSEN \& LUNDEBYE, 1996; RAINBOW, 1998; LEGRAS e col., 2000; YANG e col., 2007).

Nos crustáceos decapodes, a metalotioneína pode ser usada como indicação de contaminação por exposição ao cobre, sendo que a metalotioneína I (MT-I) é específica ao cádmio, cobre e zinco, metalotioneína (MT) II ao zinco e cádmio e metalotioneína (MT) III somente ao cobre (BROUWER e col., 2002; LI e col., 2007;).

A utilização das metalotioneínas como biomarcadores vem sendo amplamente divulgada pelos mais diversos grupos de pesquisa, nas mais diversas áreas do conhecimento, tornando-a assim ferramenta de amplo espectro de uso para determinação dos efeitos que poluentes, como o cobre, podem acarretar para a homeostase dos caranguejos de mangue. Por isso, a determinação da concentração de metalotioneína e das demais enzimas anteriormente citadas ( $\mathrm{Na} / \mathrm{K}-\mathrm{ATP}$ ase e anidrase carbônica) é de suma importância para este trabalho, uma vez que os animais expostos ao ambiente aquático previamente contaminado por cobre na forma de $\mathrm{CuSO}_{4}$, (conhecido 
principalmente como componente de algicidas frequentemente utilizados em corpos d'agua) podem mobilizar estratégias de regulação homeostática como a alteração das atividades enzimáticas e o aumento da síntese de proteína quelante do cobre (metalotioneína) a fim de evitar danos mais severos e então habitar áreas poluídas, sem que haja alterações bioquímicas e fisiológicas que possam comprometer a sobrevivência do animal. 


\section{Geral}

O objetivo geral deste estudo foi determinar os possíveis efeitos que a presença do cobre pode desencadear nos processos de equilíbrio enzimático do caranguejo de mangue Ucides cordatus.

\section{Específicos}

- Determinar a atividade da proteína de membrana $\mathrm{Na}^{+} / \mathrm{K}^{+}-\mathrm{ATPase}$ em brânquias (anteriores e posteriores) e hepatopâncreas do caranguejo de mangue Ucides cordatus, após exposição a

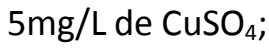

- Determinar a atividade da enzima anidrase carbônica de brânquias anteriores e posteriores do caranguejo de mangue Ucides cordatus, após exposição ao cobre na água;

- Determinar indiretamente a concentração de metalotioneína, por meio da concentração de glutationa (GSH), em brânquias (anteriores e posteriores) e hepatopâncreas, após a exposição ao cobre presente na água ao longo de 24h, 96h e 15 dias de exposição. 


\section{PARTE EXPERIMENTAL}




\section{MATERIAL E METODOS}

\section{Animais}

Neste estudo, utilizou-se 40 machos de Ucides cordatus, com massa corpórea média de ordem de 156,00 \pm 4,61 g, coletados no estuário próximo à Praia dos Pescadores, Itanhaém, Sul do Estado de São Paulo, Brasil. A Estância Balneária de Itanhaém compreende uma área de $597,4 \mathrm{~km}^{2}, 46047^{\prime} 15^{\prime \prime}$ Oeste e 24 $11^{\prime} 08^{\prime \prime}$ Sul, e está situada num ecossistema, o mangue, que consiste na transição entre terra e mar, tipicamente encontrado em regiões tropicais e subtropicais (IGARASHI,2008).

Após a coleta, os caranguejos foram aclimatados no Biotério da Universidade Presbiteriana Mackenzie durante sete dias em água do mar em salinidade 20\%, 12C:12E, $25 \pm$ $1^{\circ} \mathrm{C}$, e alimentados com alface e carne moída em dias alternados. Somente após o período de aclimatação, os experimentos com a presença de cobre na água foram realizados.

\section{Experimentos}

Os 40 caranguejos machos foram aleatoriamente divididos em quatro grupos (Controle, 24h, 96h e 15 dias de exposição ao cobre na água) e, antes de serem colocados em aquários de $15 \mathrm{~L}$ com paredes encapadas de preto, os animais foram pesados em balança Denver Instrument Company TR-402, bem como logo após o término de cada experimento, para haver controle da massa dos indivíduos ao término dos experimentos realizados com cada grupo experimental, a qual não sofreu variação significativa ao longo dos dias de experimento.

Em cada aquário de $15 \mathrm{~L}$ foram colocados $5 \mathrm{~L}$ de água do mar $20 \%$ o para que os animais não ficassem cobertos de água (sendo este mais um fator de estresse evitado) e para não impedir a sua rotina diária de imersão e emersão. A troca de água foi feita diariamente, com a adição de $5 \mathrm{mg} / \mathrm{L} \mathrm{CuSO}_{4}$ para obter $2 \mathrm{mg} / \mathrm{L}$ cobre, a fim de garantir a mesma exposição de cobre à todos os animais com aeração constante para todos os aquários. 
Ao final dos experimentos e de acordo com seus respectivos intervalos de tempo ( $24 \mathrm{~h}$, $96 \mathrm{~h}$ e 15 dias), os animais foram crio-anestesiados para dessensibilização durante 15 a 20 minutos em freezer comum. Alíquotas de hemolinfa e urina foram retiradas, com o auxílio de seringas inseridas no último pereiópodo e no pedúnculo ocular, respectivamente. Após a retirada dos fluidos supramencionados, os animais foram sacrificados por meio da separação manual das partes dorsal e ventral, e, em seguida, retirou-se alíquotas de brânquias, as quais foram separadas em anteriores e posteriores, e hepatopâncreas. 


\section{Determinação da Atividade Enzimática}

\section{$\mathrm{Na}^{+} / \mathrm{K}^{+}$- ATPase}

Para a determinação da atividade da enzima $\mathrm{Na}_{+} / \mathrm{K}^{+}$-ATPase, as amostras foram previamente armazenadas em tampão SEl composto por 0,3 $\mathrm{M}$ de sacarose, 0,01 mM de $\mathrm{Na}_{2}$ EDTA, 0,03M de imidazol, $70 \mu \mathrm{L}$ de $\beta$-mercaptoetanol e $200 \mu \mathrm{L}$ de Triton em volume final de $200 \mathrm{~mL}$ à $-80^{\circ} \mathrm{C}$. Os órgãos foram homogeneizados em cinco vezes o seu volume, em tampão SEl, e centrifugados na Centrífuga Eppendorf Centrifuge $5804 R$ a 1500x g, durante 15 minutos, à $4^{\circ} \mathrm{C}$, com consequente separação do sobrenadante.

O tampão de incubação foi composto por $100 \mathrm{mM} \mathrm{NaCl}, 8 \mathrm{mM} \mathrm{MgCl}$, $30 \mathrm{mM}$ imidazol, $0.1 \mathrm{mM}$ EDTA, com volume completado para $100 \mathrm{~mL}$ de água MilliQ. Deste volume de $100 \mathrm{~mL}$, foram retirados $20 \mathrm{~mL}$ do tampão de incubação para adicionar $3 \mathrm{mM}$ de ATP e, posteriormente, o volume foi completado para $140 \mathrm{~mL}$, com ajuste de $\mathrm{pH}$ para 7,6 com $\mathrm{HCl}$ ou $\mathrm{NaOH}$. Após este ajuste de pH, o volume foi completado para $200 \mathrm{~mL}$, sendo este dividido em 2 partes de $100 \mathrm{~mL}$ : (i) $100 \mathrm{~mL}$ recebe $13 \mathrm{mM}$ de $\mathrm{KCl}$ e (ii) recebe $2,5 \mathrm{mM}$ de ouabaína.

Para a determinação da atividade, foi necessário fazer um padrão da atividade da enzima presente em rim de rato e o preparo das amostras do padrão seguiram o mesmo processo que as amostras experimentais, com homogeneização em tampão SEI e posteriormente adicionadas às soluções contendo $\mathrm{KCl}$ ou ouabaína.

Para o preparo das microplacas de 96 poços foram pipetados $300 \mu \mathrm{L}$ de água nos 6 primeiros poços (A1-A6) e $10 \mu \mathrm{L}$ do padrão fosfato $0.65 \mathrm{mM}$ (phosphorus standart solution $0.65 \mathrm{mM}$ - Sigma Aldrich) nos poços A7- A12. Já nos poços B1 - B6 foram adicionados $10 \mu \mathrm{L}$ de homogeneizado de rim de rato e nos demais poços da microplaca foram pipetados $10 \mu \mathrm{L}$ de cada amostra experimental, e, assim como nos demais, tudo feito em triplicata.

Nos três primeiros poços $(1,2,3)$ de cada uma das variáveis, exceto nos poços que continham água, foram pipetados $100 \mu \mathrm{L}$ do tampão de incubação contendo $\mathrm{KCl}$, enquanto que nos outros três poços $(4,5,6)$ foram pipetados $100 \mu \mathrm{L}$ do tampão de incubação contendo ouabaína. As microplacas foram incubadas no escuro, durante 30 minutos.

Após a incubação, foram pipetados $200 \mu \mathrm{L}$ da mistura do reagente de cor, composto por 0,66 $\mathrm{mM} \mathrm{H}_{2} \mathrm{SO}_{4}, 9,2 \mathrm{mM}$ de molibdato de amônia e 0,33 mM de $\mathrm{FeSO}_{4} \times 7 . \mathrm{H}_{2} \mathrm{O}$ em volume de $100 \mathrm{~mL}$. A esses $100 \mathrm{~mL}$ de solução de reagente de cor, foi acionado ácido tricloroacético 
8,6\% (8,6 g em $100 \mathrm{~mL}$ de água MilliQ) em todos os poços, exceto nos poços A1-A6, que correspondem ao BRANCO.

Terminada a adição do reagente de cor, as microplacas foram lidas imediatamente em espectrofotômetro $\mu$ QUANT BioTek a $620 \mathrm{~nm}$. Após a leitura das placas, contendo as amostras para determinação da atividade da Na/K-ATPase, foi determinada a concentração proteica de cada amostra, através do método Bradford (1976) a $595 \mathrm{~nm}$.

Para a determinação da atividade específica da $\mathrm{Na}^{+} / \mathrm{K}^{+}$-ATPase foi utilizada a seguinte equação:

$\underline{\text { Abs } \mathrm{KCl} \text { - Abs Ouabaína }}$

$$
\mathrm{x} \frac{1}{\text { (Conc Prot) } x \text { (tempo incubação) }}
$$




\section{ANIDRASE CARBÔNICA}

Para a determinação da atividade da enzima anidrase carbônica, utilizou-se protocolo baseado em VITALE (1999). Primeiramente, as amostras de brânquias, tanto anteriores quanto posteriores foram homogeneizadas em tampão fosfato $25 \mathrm{mM}$ (fosfato de potássio monobásico 12,5 mM e fosfato de potássio dibásico 12,5 mM), pH 7,4 e centrifugadas a 2000x g, durante 5 minutos, a $4 \stackrel{\circ}{ } \mathrm{C}$, na Centrífuga Eppendorf Centrifuge $5804 R$.

Após a homogeneização das amostras de brânquias, foi preparado o meio de reação composto de $225 \mathrm{mM}$ manitol, $75 \mathrm{mM}$ sacarose, $10 \mathrm{mM}$ tris-base e $10 \mathrm{mM}$ de $\mathrm{NaH}_{2} \mathrm{PO}_{4}$ e este foi mantido em gelo em temperatura aproximada de 2,5 ำ. A água MilliQ foi enriquecida com $\mathrm{CO}_{2}$ durante os 15 minutos iniciais e durante todo o restante do processo.

Em um béquer de $50 \mathrm{~mL}$ foi colocado gelo para que a amostra presente no segundo béquer com volume de $10 \mathrm{~mL}$ fosse mantida em baixa temperatura durante todo $\mathrm{o}$ procedimento do protocolo de determinação da atividade da enzima anidrase carbônica. Neste béquer de $10 \mathrm{~mL}$ foram adicionados $7,5 \mathrm{~mL}$ do meio de reação e $0,05 \mathrm{~mL}$ do homogeneizado de células branquiais centrifugadas anteriormente. Após a homogeneização desta solução de meio de reação e homogeneizado, adicionou-se $1 \mathrm{~mL}$ de água saturada com gás carbônico e a cada 4 segundos, durante 20 segundos, foi anotado o pH obtido com auxílio do pHâmetro Denver Instrument Basic. Para obtenção do BRANCO, foi realizado o mesmo protocolo, porém com adição de $0,05 \mathrm{~mL}$ do tampão fosfato $25 \mathrm{mM} \mathrm{pH} \mathrm{7,4} \mathrm{em} \mathrm{vez} \mathrm{de} \mathrm{0,05} \mathrm{mL}$ de amostra experimental. Após a obtenção dos valores de pH a cada 4 segundos, fez-se necessário plotar os resultados em uma reta de regressão, onde o pH é a variável dependente e o tempo é a variável independente, e a declividade da reta corresponde à taxa catalisada (TC) da anidrase carbônica. Para as amostras do BRANCO, determinou-se a taxa não catalisada (TNC) e esta, necessária para a determinação da atividade da anidrase carbônica, é obtida por meio da seguinte equação: 


\section{METALOTIONEÍNA}

Para a determinação da concentração de metalotioneína em amostras de brânquias (anteriores e posteriores) e hepatopâncreas foi utilizado um método baseado no trabalho de VIARENGO e col. (1997), com determinação indireta, utilizando-se a concentração de glutationa (GSH) nos tecidos.

Para a homogeneização das amostras foi utilizada uma solução tampão contendo 17,12 $\mathrm{g}$ de sacarose e $0,315 \mathrm{~g}$ de Tris $\mathrm{HCl}$ em $90 \mathrm{~mL}$ de água MilliQ, com $500 \mu \mathrm{L}$ da solução estoque de PMSF (0,01722g em $1 \mathrm{~mL}$ ). O volume foi completado para $100 \mathrm{~mL}$ em pH 8,6, ajustado com $\mathrm{HCl}$ ou $\mathrm{NaOH}$. Por fim, adicionou-se 9,13 $\mu \mathrm{L}$ de $\beta$-mercaptoetanol.

Foram utilizados $5 \mathrm{~mL}$ de solução de homogeneização para cada grama de tecido utilizado. O material foi centrifugado a $30.000 x$ g, durante 45 minutos, na centrífuga HIMAC HITACHI CP 80WX Preparative Centrifuge. Após a centrifugação, foram retirados $250 \mu \mathrm{L}$ de sobrenadante e adicionados $265 \mu \mathrm{L}$ de etanol absoluto, à -20 으, e $20 \mu \mathrm{L}$ de clorofórmio, e esta solução foi homogeneizada e centrifugada a $6000 \times \mathrm{g}$, durante 10 minutos, à 4 으, na centrífuga Eppendorf Centrifuge $5804 R$.

Desta homogeneização foram retirados $300 \mu \mathrm{L}$ de sobrenadante e adicionados $20 \mu \mathrm{L}$ de $\mathrm{HCl}$ puro (37\%) e $900 \mu \mathrm{L}$ de etanol absoluto, à $-20 \stackrel{\circ}{\circ}$, com conseguinte centrifugação a $6000 x$ g, durante 10 minutos, à $4 \stackrel{\circ}{ } \mathrm{C}$, para descarte do sobrenadante. O pellet resultante dessa centrifugação foi re - suspenso com $1 \mathrm{~mL}$ da solução etanol -clorofórmio $(8,7 \mathrm{~mL}$ de etanol absoluto $+1 \mathrm{~mL}$ de clorofórmio $+0,3 \mathrm{~mL}$ de tampão de homogeneização) e novamente homogeneizado. Após esta etapa, foram adicionados $4,2 \mathrm{~mL}$ da solução de DTNB contendo 10,7228g de $\mathrm{Na}_{2} \mathrm{HPO}_{3} \times 7 . \mathrm{H}_{2} \mathrm{O}$ e 23,376g de $\mathrm{NaCl}$, em $200 \mathrm{~mL}$ de água MilliQ, em pH 8,0. Após o acerto do $\mathrm{pH}$, adicionou-se 0,3963g de DTNB dissolvido em $50 \mathrm{~mL}$ de metanol. As amostras foram novamente homogeneizadas, para, então, serem centrifugadas a 3000x g, durante 5 minutos. O sobrenadante foi retirado para leitura em espectrofotômetro com absorbância de $412 \mathrm{~nm}$.

Para a determinação da concentração de metalotioneína, baseada na concentração de GSH, foi necessário fazer uma curva padrão com solução estoque de 1 mM de GSH (PM 307,3 $\mathrm{g} \backslash \mathrm{L})$. Tubos, a partir da solução estoque, foram preparados com concentrações crescentes, que variaram de 2,5 $\mu \mathrm{M}$ a $100 \mu \mathrm{M}$, e com adição das solução de DTNB. Conforme a concentração 
de GSH encontrada em cada amostra, foi determinada a concentração de metalotioneína das brânquias e hepatopâncreas do caranguejo de mangue.

\section{Análise dos Dados}

Todos os resultados foram plotados utilizando o programa Prism Graph Pad 5 (Graph Pad Software Inc, La JOlla, EUA) e analisados com auxílio do programa Sigma Stat 3.1.

Aplicou-se num primeiro momento o teste de análise de variância (ANOVA) para todos os resultados obtidos e após os testes de normalidade para cada variável, foi aplicado o teste Kruskal-Wallis seguido do teste de Dunn's para os dados obtidos de $\mathrm{Na}^{+} / \mathrm{K}^{+}$- ATPase de hepatopâncreas, assim como os resultados obtidos para atividade da anidrase carbônica das brânquias posteriores e concentração de metalotioneína tanto das brânquias anteriores e posteriores como para hepatopâncreas, uma vez que o teste de normalidade falhou.

Para os dados de atividade das enzimas anidrase carbônica das brânquias anteriores e $\mathrm{Na}_{+} / \mathrm{K}_{+}-$ATPase das brânquias anteriores e posteriores, aplicou-se o teste Holm-Sidak após o teste ANOVA, uma vez que o teste para normalidade das amostras foi realizado com sucesso, onde para todas as figuras, letras, números e símbolos diferentes indicam diferença estatística siginificativa. 
RESULTADOS

A figura 1 mostra que nas brânquias anteriores houve redução da atividade da enzima para o grupo exposto durante 24 horas ao cobre na água, com $p<0,05$ em comparação ao grupo controle, enquanto que os animais expostos durante 15 dias ao cobre apresentaram considerável aumento da atividade da enzima, com $p<0,05$ em comparação com o grupo controle. O grupo 96h apresentou somente tendência a aumentar a atividade enzimática, uma vez que não foi observada diferença estatística em relação ao grupo controle, com p>0,05. Porém, quando os grupos experimentais são comparados entre si, todos apresentam diferença estatística significativa, com $\mathrm{p}<0.05$ para todas as comparações.

Já para as brânquias posteriores, é possível observar a mesma tendência do grupo exposto durante $24 \mathrm{~h}$ ao cobre na água, quando comparado ao grupo controle, com valor de $p<0,001$. Porém, os resultados encontrados para os grupos $96 \mathrm{~h}$ e 15 dias são opostos ao encontrado nas brânquias anteriores, onde o grupo 96h apresentou tendência a ser superior ao grupo controle, assim como o grupo exposto durante 15 dias apresentou tendência a ter menor atividade da enzima, embora não tenha havido diferença estatística significativa, com $p>0,05$. Quando comparados os grupos experimentais, houve somente diferença estatística entre os grupos $24 \mathrm{~h}$ e $96 \mathrm{~h}$, e $24 \mathrm{~h}$ e 15 dias, ambos com valor de $p<0,001$.

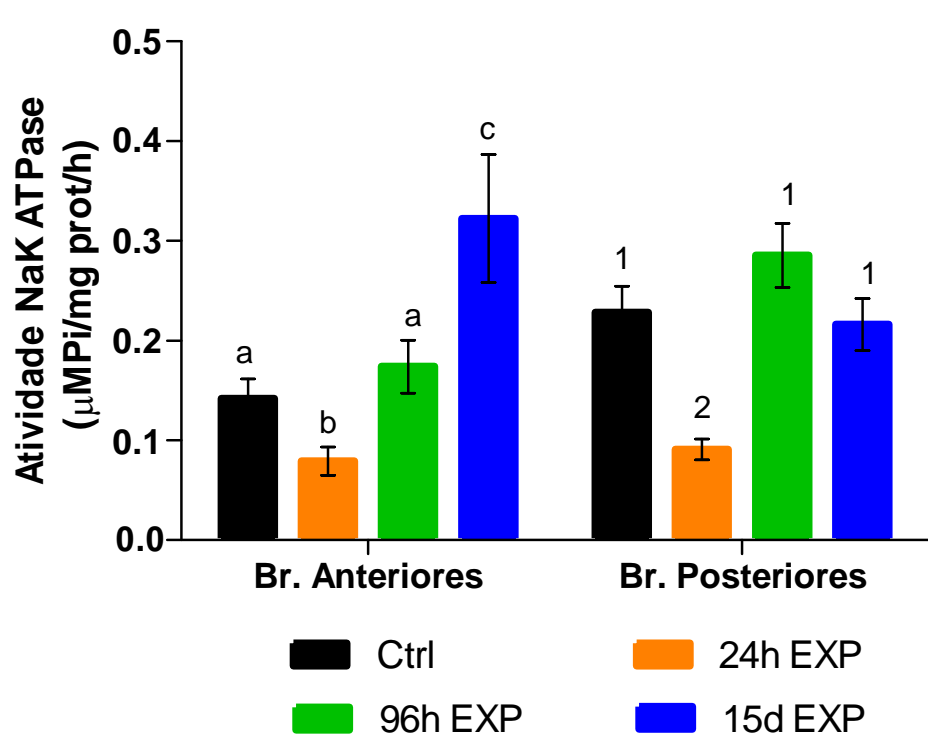

Figura 1: Determinação da atividade da $\mathrm{Na}^{+} / \mathrm{K}^{+}-\mathrm{ATPase}(\mu \mathrm{MPi} / \mathrm{mg}$ de proteína/hora) em amostras de brânquias anteriores e posteriores do caranguejo de mangue Ucides cordatus submetidos a testes agudo e crônico de exposição ao $\mathrm{CuSO}_{4}(5 \mathrm{mg} / \mathrm{L})$ durante $24 \mathrm{~h}$ e $96 \mathrm{~h}$,, e 15 dias, respectivamente $(n=10)$. 
A figura 2 apresenta a atividade da $\mathrm{Na}^{+} / \mathrm{K}^{+}$-ATPase no hepatopâncreas do caranguejo Ucides cordatus e observa-se que, quando comparados com o grupo controle, somente os animais expostos durante $96 \mathrm{~h}$ apresentaram diferença estatística significativa com $p<0,01$, enquanto que o grupo $24 \mathrm{~h}$ apresentou tendência de ser superior ao grupo controle, porém sem diferença estatística significativa, com $p>0,05$, enquanto que o grupo 15 dias possui valores bastante similares ao controle, não havendo também diferença estatística significativa $(p>0,05)$.

Já quando os grupos experimentais são comparados entre si, somente foi obtida diferença estatística significativa $(p<0,05)$ a comparação entre os grupos expostos durante $96 \mathrm{~h}$ e 15 dias, onde este último grupo apresenta acentuada redução da atividade da enzima $\mathrm{Na}^{+} / \mathrm{K}^{+}$-ATPase.

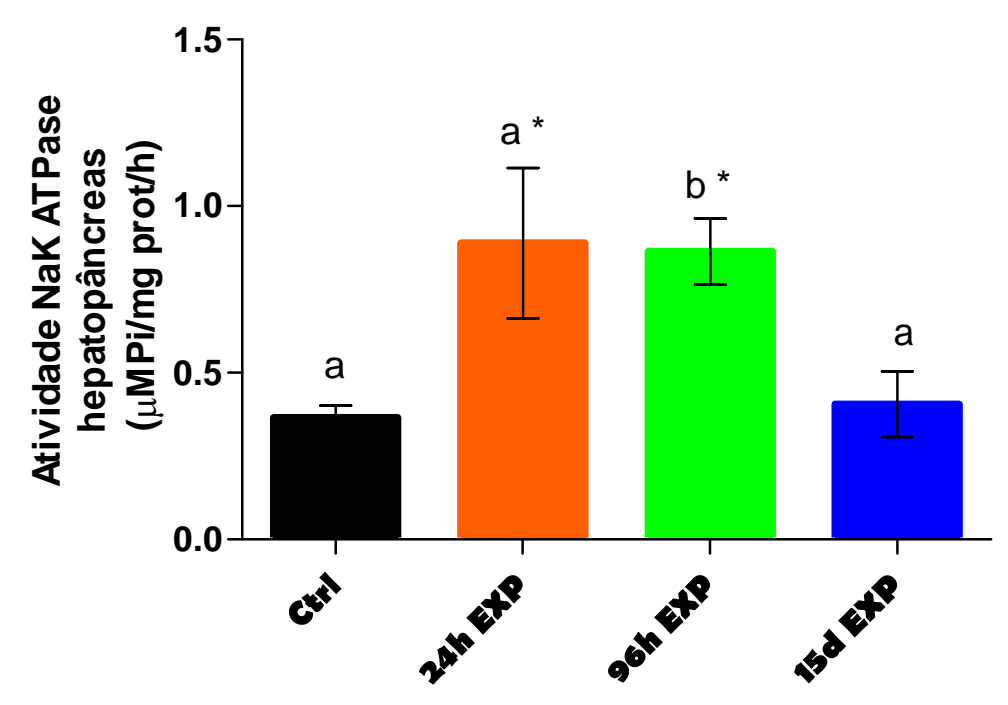

Figura 2: Determinação da atividade da $\mathrm{Na}^{+} / \mathrm{K}^{+}$-ATPase ( $\mu \mathrm{MPi} / \mathrm{mg}$ de proteína/hora) em amostras de hepatopâncreas do caranguejo de mangue Ucides cordatus submetidos à testes agudo e crônico de exposição ao $\mathrm{CuSO}_{4}(5 \mathrm{mg} / \mathrm{L})$ durante (24h e $\left.96 \mathrm{~h}\right)$ e 15 dias, respectivamente $(\mathrm{n}=10)$ 
A figura 3 apresenta variação da atividade da enzima anidrase carbônica nas brânquias anteriores, onde o grupo exposto durante $24 \mathrm{~h}$ ao cobre na água apresentou aumento considerável da enzima com $p<0,001$, assim como o grupo exposto durante 15 dias com $p<0,001$, enquanto o que grupo exposto durante $96 \mathrm{~h}$ não apresentou diferença estatística significativa $(p>0,05)$ em relação ao grupo controle, embora seja nítida a diferença estatística entre os grupos experimentais, todos com valor de $p<0,001$ para suas comparações.

Já para as brânquias posteriores, foi encontrada diferença estatística entre os grupos 96h e 15 dias de exposição em comparação ao grupo controle com $p<0,05$, enquanto que para comparação entre grupos experimentais, somente o grupo $24 \mathrm{~h}$ foi diferente estatisticamente quando comparado aos grupos $96 \mathrm{~h}$ e 15 dias com $p<0,05$, enquanto que a comparação entre $96 \mathrm{~h}$ e 15 dias apresentou valor de $p>0,05$.

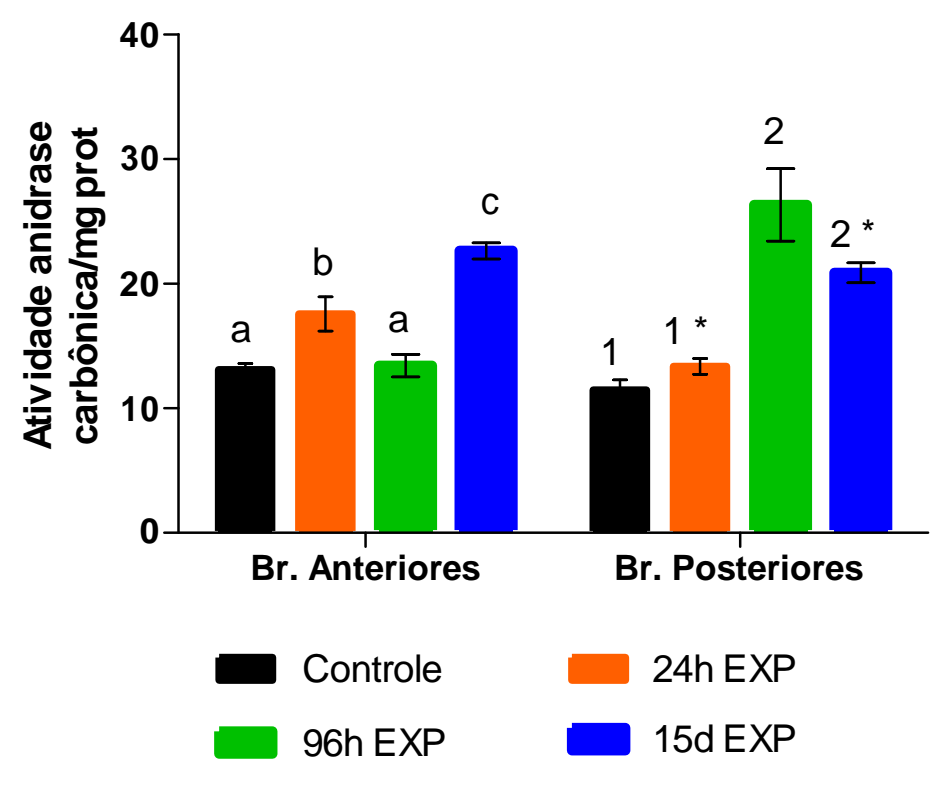

Figura 3: Determinação da atividade da anidrase carbônica/mg de proteína em amostras de brânquias anteriores e posteriores do caranguejo de mangue Ucides cordatus submetidos à testes agudo e crônico de exposição ao $\mathrm{CuSO}_{4}(5 \mathrm{mg} / \mathrm{L})$ durante (24h e $\left.96 \mathrm{~h}\right)$ e 15 dias, respectivamente. ( $\left.\mathrm{n}=10\right)$ 
A figura 4 apresenta a tendência da concentração de metalotioneína ser dependente do tempo de exposição ao cobre na água nas brânquias anteriores, embora o grupo 24h não apresentou diferença estatística do grupo controle, enquanto que os animais expostos durante 96h e 15 dias apresentaram valor de $p<0,05$ quando comparado ao grupo controle. Já quando foram comparados os grupos experimentais, o grupo exposto durante $24 \mathrm{~h}$ não foi diferente estatisticamente do grupo $96 \mathrm{~h}(\mathrm{p}>0,05)$, porém apresentou diferença estatística significativa do grupo 15 dias com $p<0.05$, enquanto que a comparação dos grupos $96 \mathrm{~h}$ e 15 dias não apresentaram diferença estatística entre si, com p>0,05.

Já para as brânquias posteriores, a tendência da concentração de metalotioneína ser dependente do tempo de exposição é uma pouco mais enfraquecida, uma vez que os animais expostos durante $96 \mathrm{~h}$ não apresentaram diferença estatística em relação ao grupo controle $(p>0,05)$, assim como o grupo $24 h(p>0,05)$, enquanto que obteve-se $p<0,05$ na comparação entre controle e grupo exposto durante 15 dias ao cobre. No entanto, quando comparados os grupos experimentais entre si, o grupo exposto ao longo de $24 \mathrm{~h}$ apresentou diferença estatística somente para o grupo $96 \mathrm{~h}$ com $p<0,05$, enquanto que é possível também observar diferença entre os grupos $96 \mathrm{~h}$ e 15 dias, com $\mathrm{p}<0,05$.

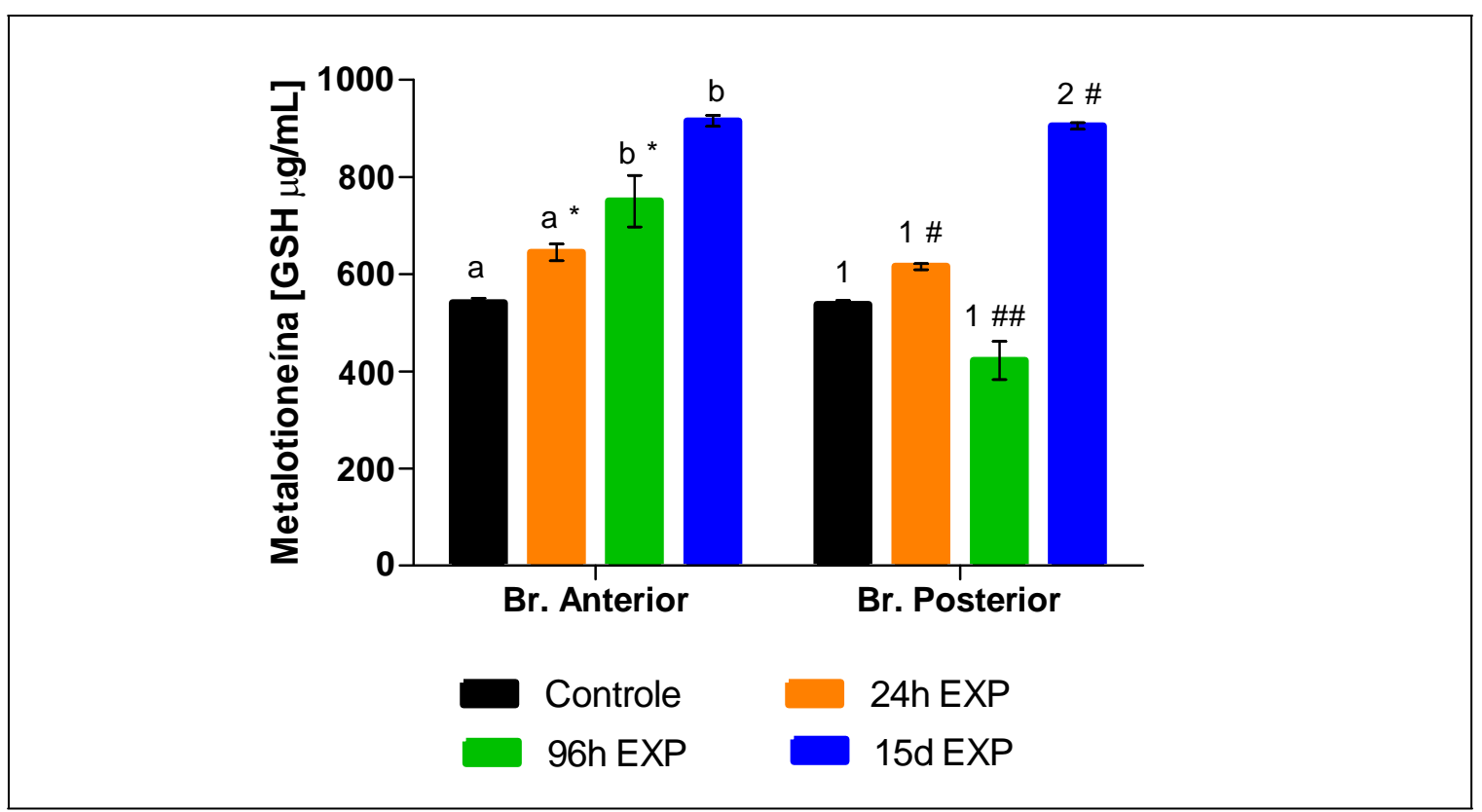

Figura 4: Determinação da concentração da metalotioneína ([GSH] ug/mL) em amostras brânquias anteriores e posteriores do caranguejo de mangue Ucides cordatus submetidos à testes agudo e crônico de exposição ao $\mathrm{CuSO}_{4}(5 \mathrm{mg} / \mathrm{L})$ durante $(24 \mathrm{~h}$ e $96 \mathrm{~h})$ e 15 dias, respectivamente $(\mathrm{n}=10)$. 
A figura 5 apresenta os resultados da concentração de metalotioneína em amostras de hepatopâncreas do caranguejo Ucides cordatus e somente houve diferença estatística na comparação com o grupo controle e grupo 15 dias de exposição $(p<0,05)$, enquanto que na comparação entre os grupos experimentais os grupos $24 \mathrm{~h}$ e $96 \mathrm{~h}$, ambos pertencentes ao teste agudo de exposição apresentaram diferença estática, assim como a comparação entre grupos 96h e 15 dias, ambos com $p<0,05$.

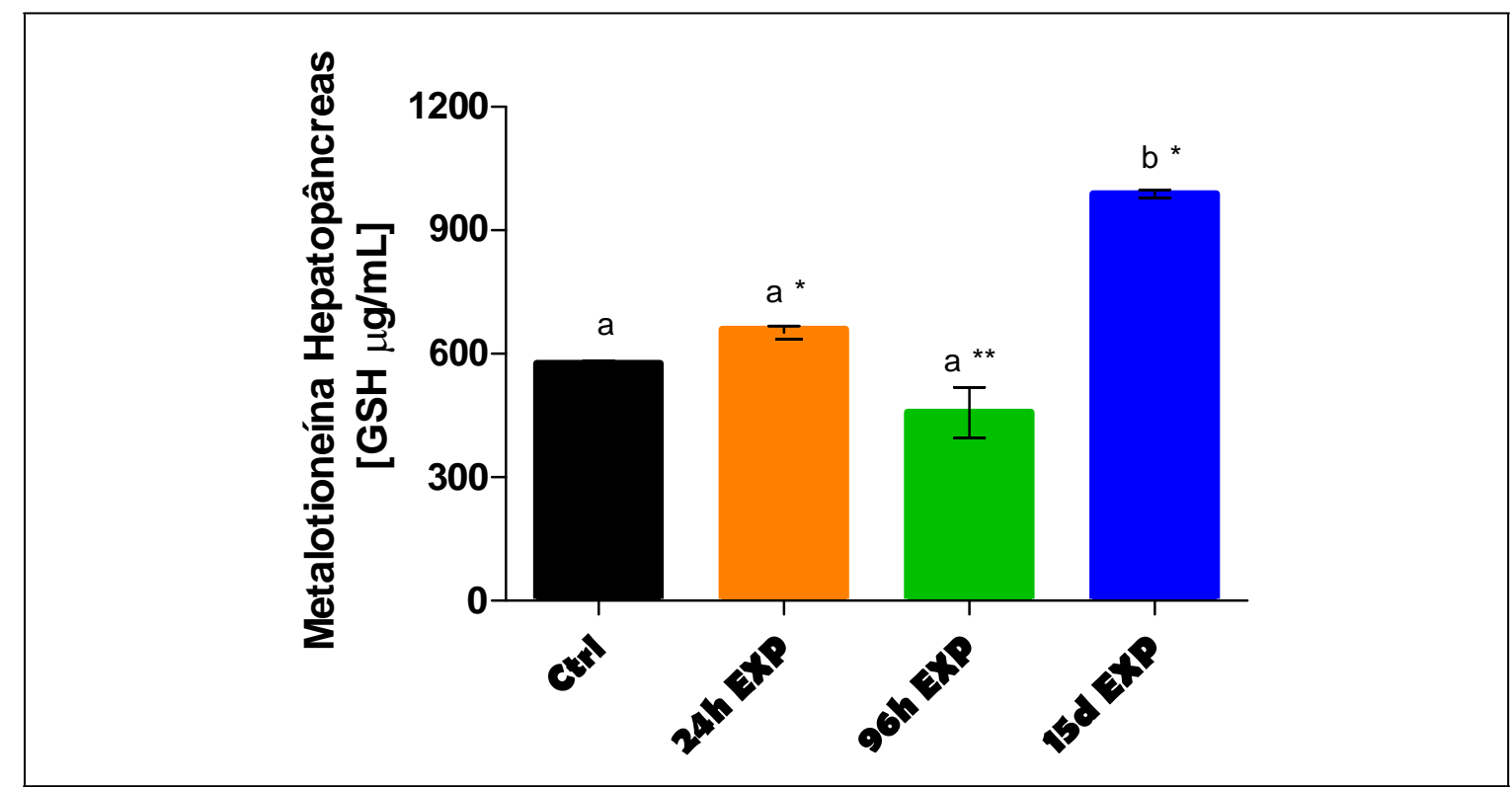

Figura 5: Determinação da concentração da metalotioneína ([GSH] ug/mL) em amostras de hepatopâncreas do caranguejo de mangue Ucides cordatus submetidos à testes agudo e crônico de exposição ao $\mathrm{CuSO}_{4}(5 \mathrm{mg} / \mathrm{L})$ durante (24h e $\left.96 \mathrm{~h}\right)$ e 15 dias, respectivamente $(\mathrm{n}=10)$. 


\section{DISCUSSAO}

Embora algumas espécies de crustáceos habitem ambientes com altas concentrações de metais pesados, as suas funções vitais, de modo geral, mantêm-se preservadas. Porém, podem ocorrer alterações nos processos de excreção e formas de destoxificação (HARRIS \& SANTOS, 2000). Os efeitos tóxicos do metal acumulado aparece quando excede um determinado patamar, passando, portanto, a agir como um desregulador dos processos celulares (HARRIS \& SANTOS, 2000) ao interferir na atividade das enzimas de um modo geral.

Como se sabe, as enzimas são proteínas catalisadoras das reações que ocorrem nos sistemas biológicos. A maioria das reações químicas das células vivas seria muito lenta se não fossem catalisadas pelas enzimas, as quais retomam a sua forma original uma vez terminada a reação (HARPER e col., 1982). Ao contrário de catalisadores não protéicos $\left(\mathrm{H}^{+}, \mathrm{OH}^{-}\right.$, ou íons metálicos), cada enzima catalisa um pequeno número de reações, frequentemente apenas uma, dado que elas possuem uma especificidade muito grande com o substrato (HARPER e col., 1982).

\section{$\mathrm{Na}^{+} / \mathrm{K}^{+}$- ATPase}

Estudos recentes sobre a ação da $\mathrm{Na}^{+} / \mathrm{K}^{+}$-ATPase nas brânquias de caranguejos eurialinos hiperosmorreguladores mostraram que as medidas obtidas da atividade desta enzima, em suspensões homogeneizadas ou purificadas de membranas, refletiam uma resposta à salinidade do ambiente. Os resultados, mostraram significativo aumento da atividade da enzima sob condições que requeriam uma vigorosa resposta omorregulatória (LUCU \& TOWLE, 2003).

O resultados obtidos no presente estudo indicam um aumento da atividade da $\mathrm{Na}^{+} / \mathrm{K}^{+}-$ ATPase nas brânquias anteriores conforme o tempo de exposição. Tal característica sugere que ocorre uma baixa habilidade de regulação na presença do metal, o que já não foi observado nas células das brânquias posteriores, quando os animais expostos durante 15 dias não apresentaram diferença estatística significativa em relação ao grupo controle, indicando, possivelmente, uma melhor regulação, uma vez que se trata de células predominantemente 
osmorregulatórias. Isso, de certa forma, corrobora os resultados obtidos por CASTILHO e col. (2001) e LUCU \& TOWLE (2003) no que diz respeito aos animais expostos durante $24 \mathrm{~h}$ e $96 \mathrm{~h}$, assim como ao grupo controle, uma vez que muitos estudos colocam a $\mathrm{Na}^{+} / \mathrm{K}^{+}$-ATPAse como tendo uma função central na tomada de sódio. Esse conjunto de dados corrobora a idéia de que a maior atividade da enzima deve ocorrer nas brânquias posteriores, cuja função principal é transporte iônico, e não nas brânquias anteriores, cuja função é predominantemente respiratória (CASTILHO e col., 2001). No entanto, no grupo exposto durante 15 dias, as brânquias posteriores apresentaram menor atividade da enzima $\mathrm{Na}^{+} / \mathrm{K}^{+}$-ATPase quando comparada com a das brânquias anteriores, sugerindo, neste caso, a existência de uma regulação mais acentuada, uma vez que o animal Ucides cordatus é um excelente hipohiperosmorregulador (SCHIMDT-NIELSEN, 2002).

Em relação aos valores da atividade da $\mathrm{Na}^{+} / \mathrm{K}^{+}$-ATPase para os dois tipos de brânquias dos animais expostos durante $24 \mathrm{~h}$, nota-se uma acentuada redução da atividade da enzima, sugerindo, neste caso, a ocorrência de uma aclimatação ao choque resultante do primeiro contato com o poluente na água, o qual se deu nas $24 \mathrm{~h}$ iniciais de exposição. Tal condição resultou em uma hiper-regulação e posteriormente em uma hiporregulação, já que os valores encontrados para o grupo 15 dias foram bastante elevados para as brânquias anteriores. Por outro lado, houve uma contínua hiper-regulação nas brânquias posteriores, o que levou a uma redução da atividade enzimática ao longo do período de experimentação.

Já em relação às células de hepatopâncreas, a atividade da $\mathrm{Na}^{+} / \mathrm{K}^{+}$-ATPase foi aproximadamente três vezes superior à das brânquias (tanto anteriores quanto posteriores) e não há aparente dependência do tempo, corroborando os resultados de MONTEIRO e col. (2005), já que a atividade da enzima no grupo exposto durante 15 dias não apresentou diferença significativa em relação à atividade encontrada no grupo controle, mas no grupo $24 \mathrm{~h}$ houve tendência de aumento da atividade da enzima. Tal resultado se contrapõe aos dados obtidos por MONTEIRO e col. (2005), uma vez que o grupo 96h apresentou diferença estatística em relação ao grupo controle, indicando, possivelmente, que o cobre atuou como um agente estimulador da atividade da $\mathrm{Na}^{+} / \mathrm{K}^{+}$-ATPase, podendo ser este, portanto, um mecanismo de proteção contra o poluente na água. 


\section{ANIDRASE CARBÔNICA}

A anidrase carbônica é tida como uma enzima central nos processos de integração do transporte iônico e osmorregulação em crustáceos eurialinos e a inibição da atividade desta enzima pode, potencialmente, afetar o transporte e a regulação de vários íons (SKAGGS \& HENRY, 2002).

Os metais pesados como prata, cádmio, cobre e zinco inibem a atividade da anidrase carbônica associada ao citoplasma assim como a da anidrase carbônica associada à fração da membrana (SKAGGS \& HENRY, 2002). Diferenças na sensibilidade da anidrase carbônica à toxicidade dos metais pesados podem também ter impacto na habilidade do organismo intacto em interagir com o ambiente (SKAGGS \& HENRY, 2002).

É importante mencionar que alterações que eventualmente possam ocorrer na membrana basal também podem causar distúrbios nas trocas gasosas, uma vez que tais distúrbios podem afetar o funcionamento da anidrase carbônica responsável pela facilitação da passagem de $\mathrm{CO}_{2}$ do sangue para o meio ambiente (BURNETT e col., 1981; BURNETT \& McMAHON, 1985; LAWSON e col., 1995).

Os nossos resultados mostram que a atividade da anidrase carbônica nas brânquias anteriores não é dependente do tempo, ao menos de forma clara, já que os animais expostos durante $96 \mathrm{~h}$ apresentaram redução da atividade enzimática em relação ao grupo exposto durante $24 \mathrm{~h}$, e praticamente se equipararam ao grupo controle, indicando haver potencial regulação e aclimatação destes animais após as primeiras $24 \mathrm{~h}$ de exposição ao ambiente poluído por cobre. Porém, tal regulação pode ter sido afetada ao longo dos 15 dias de exposição, já que, após este período, os animais apresentaram um aumento acentuado da atividade da anidrase carbônica. No entanto, estes resultados não corroboram os resultados obtidos por SPICER e col., 1998; PÁEZ-OSUNA e col., 1995; VITALE e col., 1999. O aumento da atividade enzimática pode indicar que os animais, quando expostos a um ambiente hostil por um período prolongado como por 15 dias, foram induzidos a realizar ajustes dos seus mecanismos osmorregulatórios, associados ao transporte iônico, para que conseguissem sobreviver em tal ambiente hostil. 


\section{METALOTIONEÍNA}

Metalotioneínas que se ligam ao cobre, cádmio e zinco têm sido encontradas em diversas espécies de caranguejos. Tais metais podem ser destoxificados e excretados como grânulos do epitélio do hepatopâncreas, e a cutícula das brânquias pode, em algumas espécies de crustáceos, também atuar na tomada e estocagem de metais (HARRIS \& SANTOS, 2000).

Que os metais tóxicos possam se ligar a diversas proteínas é um fenômeno bem conhecido. Em muitos organismos, as metalotioneínas exercem função primordial no seqüestro e destoxificação de metais, provavelmente para assegurar a homeostase celular (RTAL e col., 1996).

A indução de metalotioneínas tem sido frequentemente considerada um dos mecanismos responsáveis pelos ajustes observados e pelo aumento da tolerância de diversos organismos a metais (HOGSTRAND e col., 1994). É bem sabido que a indução de metalotioneína, que é uma proteína rica em cisteína e que possui propriedade destoxificatória, ocorre em invertebrados aquáticos expostos a ambientes ricos em cádmio, zinco e cobre (LI e col., 2007).

O aumento da síntese de metalotioneína é uma resposta bioquímica à alta disponibilidade de metais no ambiente, uma das características típicas de um biomarcador. DEPLEDGE (1993) entende tal resposta como sendo uma "variação bioquímica, celular, fisiológica ou comportamental que possa ser mensurada no tecido ou em amostras de fluidos corpóreos, ou mesmo no organismo intacto, a qual fornece evidências da exposição e efeitos de um ou mais poluentes químicos (e/ou radiação)" (AMIARD e col., 2006). Entendida dessa maneira, a metalotioneína pode exercer um efeito protetor junto a sistemas enzimáticos específicos (ROESIJADI, 1992).

É importante salientar que muitos estudos sugerem que a indução da metalotioneína tanto nas células branquiais quanto intestinais não aparenta facilitar a tomada de metal. Em moluscos, por exemplo, a taxa de tomada de metais pelas brânquias não é alterada pela indução de metalotioneína (ROESIJADI, 1992).

O acúmulo de cobre ligado à metalotioneína parece ocorrer de modo proporcional e linear em função das concentrações de exposição ao metal (ROESIJADI, 1992). Geralmente, a expressão de metalotioneína aumenta com a elevação da concentração de metais indutores de metalotioneínas, refletindo a biodisponibilidade destes metais no ambiente externo 
(MONSERRAT e col., 2006). No nosso estudo, tal condição foi encontrada nas brânquias anteriores, enquanto que nas brânquias posteriores não houve diferença estatística entre o teste agudo e o teste realizado no grupo controle. Porém, o grupo exposto durante 15 dias apresentou diferença em relação ao grupo controle, tanto nas brânquias como no hepatopâncreas.

A exposição sub-letal ao cobre pode levar ao aumento da concentração hepática de metalotioneína. Um estudo realizado com peixes do Atlântico revelou um aumento da metalotioneína branquial durante exposição ao cobre (GROSELL e col., 1997). Os níveis de metalotioneínas presentes no hepatopâncreas do camarão Macrobrachium rosenbergii aumentaram quando os animais foram expostos ao cobre presente na água (LI e col., 2007). Quando camarões foram expostos a altas doses de cobre, houve indução da transcrição do gene da metalotioneína e aumento do nível de RNAm no hepatopâncreas, aumentando assim a síntese de metalotioneína. Portanto, é por meio deste processo que o conteúdo de metalotioneína pode eventualmente aumentar, na presença de altas concentrações de cobre no meio externo (LI e col., 2007). LEGRAS e col. (2000) demonstraram que as concentrações de metalotioneínas são maiores no hepatopâncreas que nas brânquias de Carcinus maenas. Os nossos resultados não corroboram aqueles obtidos por Legras e col. (2000), uma vez que os valores de concentração de metalotioneína encontrados para o hepatopâncreas e as brânquias de Ucides cordatus foram bem próximos um do outro. O que é importante salientar aqui que foram utilizados métodos bastante distintos, sendo que o presente estudo utilizou protocolo baseado no trabalho de VIARENGO e col. (1997), enquanto que LEGRAS e col. (2000) utilizaram técnicas baseadas em THOMPSON \& COSSON (1984) quando a concentração de metalotioneína foi determinada através de análise diferencial de pulso polarográfico. 


\section{CONCLUSAO}

É bem conhecido que animais expostos a ambientes hostis, como os manguezais poluídos por diversos metais, possuem habilidades de se aclimatar e alterar seus mecanismos de homeostase para que possam sobreviver em tais ambientes, cada vez mais são comuns no nosso planeta. Portanto, a determinação da atividade de algumas enzimas relacionadas com o estresse oxidativo foi de suma importância para a compreensão de alguns dos mecanismos de homeostase utilizados pelos caranguejos de mangue Ucides cordatus. Os resultados obtidos a partir do presente estudo nos permitem concluir que:

- a atividade da $\mathrm{Na}^{+} / \mathrm{K}^{+}$-ATPase foi bastante distinta nas brânquias anteriores e posteriores. Nas primeiras, observou-se uma maior atividade da enzima em função do tempo de exposição, enquanto que nas segundas, houve uma redução da atividade enzimática ao longo do tempo, indicando que estas brânquias, predominantemente osmorregulatórias, são capazes de regular o transporte de cobre;

- a atividade da $\mathrm{Na}^{+} / \mathrm{K}^{+}$-ATPase no hepatopâncreas foi quase três vezes superior àquela observada nas brânquias e não apresentou dependência em relação ao tempo de exposição, sugerindo que algum mecanismo de proteção contra o poluente possa ter sido estimulado, de maneira a permitir a ocorrência de algum tipo de aclimatação ao ambiente poluído;

- a atividade da anidrase carbônica foi afetada de modo direto pela exposição ao cobre e os nossos resultados sugerem que o aumento da atividade da enzima esteja relacionado com o incremento dos processos iono e osmorregulatórios para que, à semelhança do que foi observado em relação à $\mathrm{Na}^{+} / \mathrm{K}^{+}$-ATPase, pudesse ocorrer algum tipo de aclimatação ao meio contendo doses elevadas de cobre;

- a indução da metalotioneína na presença do cobre na água foi bastante similar nas brânquias anteriores, nas brânquias posteriores e no hepatopâncreas, embora as brânquias anteriores tenham apresentado uma dependência em relação ao tempo de exposição, enquanto que no hepatopâncreas parece ter ocorrido uma regulação da concentração de cobre e, consequentemente, uma indução da proteína quelante de cobre, a metalotioneína. 


\section{Consideraçoes Finais}

É sabido que a exposição de crustáceos a aguas poluídas resulta em danos branquiais, os quais por sua vez podem resultar em prejuízos à função respiratória. Como as brânquias de crustáceos também estão envolvidas na osmorregulação e ionorregulação tais danos resultam em sérios prejuízos à homeostase desses animais. Quando crustáceos são expostos a altas concentrações de metais, observa-se com frequência o aparecimento de algumas disfunções regulatórias (LAWSON e col., 1995; SPICER e col., 1998). A partir do momento em que a poluição por metais aumentou, principalmente em áreas tropicais, a condução de estudos para quantificar as concentrações desses metais em espécies comerciais tem sido cada vez mais importante (PÁEZ-OSUNA e col., 1995).

Da mesma forma que a presença de metais impõe alterações nos ecossistemas aquáticos e conseqüentemente nos organismos vivos que neles habitam, os corpos de água que atuam como receptadores desses metais podem influenciar a sua distribuição, transporte e biodisponibilidade e isso se deve às interações que esses metais tendem a estabelecer com outras partículas dissolvidas na água.

O cobre é um dos metais de transição mais abundantes na natureza e um componente essencial de todos os tecidos vivos (BOSSUYT \& JANSSEN, 2005). Porém, quando presente em altas concentrações, torna-se tóxico aos peixes e a outros organismos aquáticos (BOSSUYT \& JANSSEN, 2005). Concentrações tóxicas de cobre ocorrem principalmente como conseqüência de atividades de mineração, indústrias e agricultura (MONTEIRO e col., 2005).

No que diz respeito à dieta, a ação predominantemente tóxica do cobre consiste na geração de radicais livres nos tecidos onde este metal é acumulado. Além disso, a ação tóxica do cobre a partir da dieta ocorre no hepatopâncreas, incluindo a redução da sua motilidade e a inibição de enzimas digestivas. Assim, o aumento da concentração de cobre na água afeta as funções das brânquias e a sua principal ação tóxica consiste na perturbação da homeostase de sódio (BURY, 2003).

Estudos experimentais têm demonstrado que as brânquias de Carcinus maenas podem se recuperar de danos ocorridos durante exposição prolongada a concentrações sub-letais de cobre (LAWSON e col., 1995). A recuperação de peixes expostos a metais envolve o reparo de danos branquiais e a restauração das funções ionorregulatórias e respiratórias. No caso de 
Carcinus maenas, a redução da permeabilidade ao cobre e o grande poder em seqüestrá-lo têm sido demonstrados (LAWSON e col., 1995). Como as brânquias de crustáceos exercem função proeminente na osmorregulação, regulação iônica e trocas gasosas, é possível antecipar que os fatores que influenciam os seus processos fisiológicos, possam também afetar as ultraestruturas branquiais (LAWSON e col., 1995).

Estudos experimentais realizados com crustáceos têm demonstrado que o cobre se liga à metalotioneína e está envolvido na síntese de hemocianina, da anidrase carbônica e de outras proteínas que são indispensáveis a estes artrópodes (LI e col., 2007).

\section{Osmorregulação}

Revisões recentes acerca da fisiologia dos órgãos osmorregulatórios de crustáceos têm enfatizado as brânquias como o principal órgão responsável pela homeostase do fluido extracelular desses artrópodes, principalmente das espécies aquáticas, além das espécies semi-terrestres (FREIRE e col., 2008). As brânquias dos crustáceos, além de permitirem a troca de gases respiratórios, participam ativamente dos processos osmo e ionorregulatórios (PEQUEUX, 1995), da regulação ácido-base da hemolinfa e da excreção de nitrogênio (metabólitos e produtos) (MASUI e col., 2003). Segundo SOEGIANTO e col. (1999), as brânquias constituem a maior porta de entrada de metais e atuam como um estoque transitório destes. Ainda, de acordo com NAKATANI (1966), as brânquias dos animais aquáticos possuem a habilidade de excretar metais (WU \& CHEN, 2005), sendo, portanto, um local de depuração de metais como o cobre nesses organismos (LAUREN \& McDONALD, 1985; VITALE e col., 1999; GROSELL \& WOOD, 2002; MARTINS e col., 2011).

Células epiteliais delgadas estão presentes em maior quantidade nas brânquias anteriores, enquanto que células espessas ou ionócitos, cuja superfície da membrana é altamente ampliada por dobras apicais e invaginações basolaterais, estão envolvidas no transporte iônico, principalmente nas brânquias posteriores (ALCORLO e col., 2006; TSAI \& LIN, 2007; MARTINS e col., 2011).

O hepatopâncreas, órgão análogo ao fígado, combina muitas funções hepáticas, do pâncreas e do intestino de vertebrados (MANDAL e col., 2003), e exerce funções importantes em diversos processos metabólicos nos crustáceos (CACECI e col., 1988; BHAVAN \& GERALDINE, 2000). Estudos acerca da estrutura, desenvolvimento, fisiologia, metabolismo e bioquímica do hepatopâncreas concluíram que este é um órgão digestório com funções que 
incluem absorção, digestão, armazenamento e secreção de substâncias (CACECl e col., 1988; WU e col., 2008). Curiosamente, as células E (embriônicas) do que se desenvolvem nos demais três tipos celulares do hepatopâncreas, neste estudo, apresentam concentrações de cobre muito similares às das demais células, mesmo possuindo poucos vacúolos para armazenamento do metal (CHAVEZ-CROOKER e col., 2001).

Em peixes, durante exposição crônica a concentrações subletais de metais, com freqüência ocorrem ajustes que incluem o restabelecimento das taxas de transporte iônico a níveis normais (HOGSTRAND e col., 1995), enquanto que camarões expostos ao cobre perderam completamente sua habilidade de regulação, indicando que a capacidade osmorregulatória pode ser usada para detectar os efeitos adversos do cobre em níveis subletais (BAMBANG e col., 1995).

Alguns mecanismos de ajuste podem incluir redução da tomada de metal, indução da ligação de metais à metalotioneína, síntese compensatória de ATPases que transportam íons e proliferação de ionócitos. Há evidências indiretas que sugerem que a indução de metalotioneína branquial pode ser um dos mecanismos pelos quais a truta de água doce, Oncorhynchus mykiss, realiza ajustes quando exposta ao zinco e a outros metais (HOGSTRAND e col., 1994), sendo este um resultado muito similar ao encontrado para a concentração de metalotioneína nas brânquias anteriores e posteriores.

Os distúrbios osmorregulatórios induzidos pelo cobre estão associados ao aumento da permeabilidade epitelial e inibição da tomada iônica ativa, levando a uma redução da atividade da $\mathrm{Na}^{+} / \mathrm{K}^{+}$-ATPase e diminuição do número de células de cloreto ativas (MONTEIRO e col., 2005). LUCU e col. (2008) sugerem que a redução da osmolaridade é responsável pelo aumento da atividade da $\mathrm{Na}^{+} / \mathrm{K}^{+}$-ATPase. Em peixes, o cobre causa uma redução de sódio e cloreto, no plasma devido à perda dos mecanismos responsáveis pela regulação iônica. Em baixas concentrações de cobre, a tomada ativa de íons aparentemente diminui como conseqüência da inibição da atividade da $\mathrm{Na}^{+} / \mathrm{K}^{+}$-ATPase, muito embora outros estudos não tenham confirmado tal relação (MONTEIRO e col., 2005).

Os distúrbios ionorregulatórios observados nas brânquias resultam da exposição a metais, embora os mecanismos subjacentes possam variar conforme o metal (HOGSTRAND e col., 1995). De modo geral, a perturbação da ionorregulação resulta da inibição das enzimas envolvidas no transporte iônico que ocorre nas brânquias (BURY \& WOOD, 1999) e o presente estudo corrobora os autores supracitados. 
Nos crustáceos, o mecanismo responsável pela hipo-hiperosmorregulação aparenta estar correlacionado com a redução da concentração de íons na hemolinfa $\left(\mathrm{Na}^{+}, \mathrm{Ca}^{2+}, \mathrm{K}^{+}, \mathrm{Mg}^{2+}\right.$, $\mathrm{Cl}^{-}$) e inibição da atividade da $\mathrm{Na}^{+} / \mathrm{K}^{+}$-ATPase nas brânquias (BAMBANG e col., 1995). Tais correlações podem ser observadas, por exemplo, a partir do efeito da presença do cálcio no metabolismo do sódio, o que afeta indiretamente a tomada de cobre.

\section{Sódio}

O cobre interfere nas rotas de tomada de sódio por meio da competição por rotas de tomada deste cátion nas brânquias dos organismos de água doce, afetando não apenas o gradiente de sódio mas também exercendo efeitos inibitórios sobre enzimas relacionadas à osmorregulação, como a Na $\mathrm{K}^{+}$-ATPase (LAUREN \& McDONALD, 1985; GROSELL e col., 2002) e a anidrase carbônica (VITALE e col., 1999; MARTINS e col., 2011), e tais efeitos podem estar relacionados aos mecanismos envolvidos na toxidez aguda provocada pelo metal (VITALE e col., 1999; GROSELL e col., 1997; GROSELL \& WOOD, 2002; MARTINS e col., 2011).

Por outro lado, distúrbios no equilíbrio ácido-base, causados presumidamente por restrições às trocas gasosas, têm sido reportados para Carcinus maenas, após exposição aguda ao cobre (BOITEL \& TRUCHOT, 1989).

A redução da concentração de sódio no plasma pode ser atribuída à perda de células de cloreto, por uma inibição direta do canal apical de sódio ou por uma inibição da anidrase carbônica (MONTEIRO e col., 2005).O efeito da toxidez do cobre em peixes pode envolver uma redução da afinidade por transportadores de sódio (inibição competitiva) e também uma redução na capacidade da tomada de sódio (inibição não competitiva) (MATSUO e col., 2005). As principais pesquisas indicam e concordam entre si que o sódio é movido através do epitélio em direção à hemolinfa, passando por duas etapas que envolvem o antiporte apical $\mathrm{Na}^{+} / \mathrm{H}^{+}$e a $\mathrm{Na}^{+} / \mathrm{K}^{+}$-ATPase basolateral. Portanto, a integridade estrutural das membranas é essencial para o correto funcionamento das trocas iônicas e osmorregulação (VIARENGO, 1985; LAWSON e col., 1995; MARTINEZ e col., 1999). 


\section{Transporte de Cobre}

O cobre é um elemento essencial e ao mesmo tempo um dos metais mais tóxicos, e por estas razões o transporte, o depósito e o metabolismo deste metal devem proteger as células contra os seus efeitos tóxicos (RTAL e col., 1996).

Experimentos realizados por McGEER e col. (2000) demonstraram que alterações fisiológicas e celulares não consistem numa cascata aleatória de eventos, mas sim numa série ordenada e sincronizada destes, envolvendo os diferentes sistemas corpóreos e integrando ao mesmo tempo o animal ao seu meio ambiente. Tal ordenação de eventos pode ser explicada pela existência de um controle fisiológico fino e coordenado (RTAL e col., 1996).

A regulação fina das concentrações celulares de cobre nos diferentes órgãos reforça a importância deste metal em processos essenciais, ao mesmo tempo em que devam existir mecanismos que previnam o seu excesso (GROSELL e col., 2004). A regulação da concentração citoplasmática do cobre parece envolver rotas de entrada e saída do metal.

O cobre entra na célula através de canais e caminhos sensíveis ao sódio, podendo causar toxidez aguda pela inibição da $\mathrm{Na}^{+} / \mathrm{K}^{+}$-ATPase no tecido branquial e, consequentemente, causar distúrbios ionorregulatórios no corpo todo (BOUSKILL e col., 2006). Este tipo de tomada está potencialmente sob controle fisiológico. Há, portanto, dois mecanismos potenciais para a tomada de metais traço dissolvidos no meio: (i) ligação a uma molécula carreadora específica para metais traço; (ii) entrada por rotas de tomada da maioria dos íons (RAINBOW, 1997).

Outra possível rota de tomada de metais presentes em solução envolve sistemas de bombas que requerem energia. Metais como sódio, potássio, cálcio e magnésio são rotineiramente transportados através de membranas hidrofóbicas, por meio de canais dependentes de energia, como por exemplo, o sistema $\mathrm{Na}^{+} / \mathrm{K}^{+}$-ATPase (SIMKISS \& TAYLOR, 1989; RAINBOW, 1995). 


\section{Metabolismo}

O aumento do metabolismo aeróbio pode claramente se refletir em um aumento do consumo de oxigênio ou em um aumento da geração de produtos metabólicos, durante exposição ao cobre. Em nível macromolecular, talvez possam ocorrer alterações da atividade de enzimas envolvidas no metabolismo e funções críticas para a sobrevivência das células (ex.: regulação iônica e hiper-regulação da atividade da $N A^{+} / K^{+}$-ATPase) (HANDY, 2003).

Um aumento do metabolismo pode, por exemplo, ser necessário para restaurar biomoléculas danificadas pelo acúmulo de cobre durante reações redox (MASON \& JENKINS, 1995) ou por processos de destoxificação, como a produção de metalotioneína (AMIARD e col., 2006), ou, ainda, pelo armazenamento de cobre na forma de grânulos (DE SCHAMPHELAERE e col., 2007).

Substâncias tóxicas podem causar danos ao tecido branquial, reduzindo o consumo de oxigênio nos organismos aquáticos (SARAVANA \& GERALDINE, 2000). As adaptações bioquímicas mais importantes que contribuem para a sobrevivência em anaerobiose incluem: (i) manutenção das altas reservas de combustível, como o glicogênio; (ii) mecanismos para minimizar a acidose metabólica, com aumento da capacidade de tamponamento, de alterações compensatórias de determinados íons ou de alteração do tipo de produto final; (iii) uso de rotas alternativas para aumento da produção anaeróbica de ATP e, (iv) depressão da taxa metabólica (MACIEL e col., 2008). Uma hipóxia moderada decorrente de danos provocados no tecido branquial também caracteriza os estágios mais avançados do processo de intoxicação (HANDY, 2003).

Mesmo que os processos físicos de ingestão propriamente ditos não tenham sido afetados, é ainda possível que a aquisição de energia seja reduzida por uma diminuição da eficiência de assimilação, e isto pode ser resultado da inibição da atividade de enzimas digestivas do hepatopâncreas. CHEN e col. (2002) demonstraram que altas concentrações de cobre inibem a atividade enzimática dos fluidos digestivos de diversos invertebrados bênticos (DE SCHAMPHELAERE e col., 2007). 


\section{Enzimas}

Numa gama grande de crustáceos, com diferentes capacidades osmorregulatórias, a atividade da $\mathrm{Na}^{+} / \mathrm{K}^{+}$-ATPase das brânquias está relacionada com o gradiente de concentração osmótica (i.e., gradiente de sódio) mantido entre a hemolinfa e o meio externo (LUCU \& TOWLE, 2003). Nesse sentido, nos crustáceos, o avanço evolutivo se deu quando a $\mathrm{Na}^{+} / \mathrm{K}^{+}-$ ATPase assumiu um papel importante na manutenção do gradiente de concentração osmótica entre a hemolinfa e meio aquático, sendo este um pré-requisito para a incursão dos crustáceos no ambiente de água doce, a partir do ambiente de água salobra (LUCU e col., 2000).

A $\mathrm{Na}^{+} / \mathrm{K}^{+}$-ATPase é uma das moléculas-chave envolvidas no transporte de sódio (MASUI, 2003), além de exercer função importante na regulação iônica de peixes. Por exemplo, a atividade da $\mathrm{Na}^{+} / \mathrm{K}^{+}$-ATPase foi reduzida em brânquias de Oncorhynchus kisutch e Platichthys flesus após exposição ao cobre. BAMBANG e col. (1995) propõem que a perda da capacidade de regular a concentração iônica na hemolinfa do camarão Penaeus japonicus resulta na perda parcial ou total da capacidade hiper-hipo osmorregulatória, em decorrência ao menos parcialmente de uma inibição direta dos efeitos do cobre sobre a atividade da $\mathrm{Na}^{+} / \mathrm{K}^{+}$-ATPase das brânquias. No entanto, alterações na água e/ou alterações da permeabilidade das brânquias, hepatopâncreas e glândula antenal a íons, assim como variações do espaço extracelular e da taxa de produção de urina também podem contribuir para alterar os níveis de concentração iônica e osmolaridade da hemolinfa (BAMBANG e col., 1995; PÉQUEUX, 1995; TOWLE e col., 2001; TOWLE \& WEIHRAUCHI, 2001; MASUI, 2003).

O cobre é um agente tóxico que afeta a osmorregulação de peixes, pois atua na redução da concentração de sódio do plasma, no influxo branquial de sódio e inibe a atividade da $\mathrm{Na}^{+} / \mathrm{K}^{+}$-ATPase das brânquias (BROOKS \& MILLS, 2003). LI e col. (1998) demonstraram de modo muito claro que a $\mathrm{Na}^{+} / \mathrm{K}^{+}$-ATPase é extremamente sensível ao cobre, tanto por inibição não competitiva quanto por tipos mistos de efeitos inibitórios do metal sobre esta enzima.

As respostas fisiológicas coordenadas mediante exposição ao cobre na água são extremamente importantes. LAUREN \& McDONALD $(1985 ; 1986)$ demonstraram que a truta arco-íris (Oncorkynchus mykiss) sofreu uma redução inicial da ordem de $55 \%$ na tomada máxima de sódio quando exposta de modo contínuo a $0,86 \mu \mathrm{mol} / \mathrm{L}$ de cobre, ocorrendo, no entanto, uma recuperação gradual após um período de 28 dias. Tal condição não se deu por causa de uma grande alteração da atividade da $\mathrm{Na}^{+} / \mathrm{K}^{+}$-ATPase per se, mas devido a um aumento da afinidade das brânquias pela tomada de sódio (o valor de $\mathrm{Km}$ indicou turnover e 
modificação dos transportadores de sódio nas brânquias (HANDY, 2003). Outros estudos demonstraram que houve uma redução da atividade da $\mathrm{Na}^{+} / \mathrm{K}^{+}$-ATPase em função do tempo, com redução da cinética de transporte de sódio e consequente redução dos níveis corpóreos deste íon, quando trutas (Oncorkynchus mykiss) foram expostas ao cobre (LI e col., 1998).

Os experimentos realizados por MASUI e col. (2005) mostraram que a atividade da $\mathrm{Na}^{+} / \mathrm{K}^{+}$-ATPase nas brânquias de Carcinus danae é amplamente regulada pelas concentrações citoplasmáticas de sódio, potássio e magnésio, e pela concentração iônica de $\mathrm{NH}_{4}{ }^{+}$da hemolinfa, o que sugere que a $\mathrm{Na}^{+} / \mathrm{K}^{+}$-ATPase possui função significativa no que tange as interações catiônicas envolvidas nos ajustes bioquímicos de Carcinus danae sob estresse salino (LUCU e col., 2000; MASUI e col., 2005).

A alteração funcional da $\mathrm{Na}^{+} / \mathrm{K}^{+}$-ATPase exerce papel fundamental na determinação da concentração iônica e osmótica na hemolinfa de crustáceos. HANSEN (1992) demonstrou que a redução de 50 a $60 \%$ da atividade da $\mathrm{Na}^{+} / \mathrm{K}^{+}$-ATPase em Carcinus maenas durante uma semana de exposição a $10 \mathrm{mg} \mathrm{Cu}{ }^{2+} / \mathrm{L}$ resultou numa redução de $40 \%$ da concentração de sódio na hemolinfa (HEBEL e col., 1997).

Em crustáceos marinhos osmoconformistas, como Calapsa hepática, Cancer e Nephrops, a hemolinfa é isosmótica em relação ao meio marinho e a atividade específica da $\mathrm{Na}^{+} / \mathrm{K}^{+}$-ATPase foi reportada como sendo um detector de limites, podendo até mesmo atuar sobre estes. Como a atividade da enzima em crustáceos marinhos é menor que aquelas encontradas em crustáceos estuarinos e dulcícolas, o gradiente de sódio entre a hemolinfa e o meio se encontra correlacionado de maneira positiva com a atividade da $\mathrm{Na}^{+} / \mathrm{K}^{+}$-ATPase (HARRIS \& BAYLISS, 1988; LUCU e col., 2000).

A ouabaína é responsável por inibir a respiração de muitas células animais, incluindo as do cérebro e rins. Uma vez que a respiração celular é regulada pela velocidade de hidrólise do ATP intracelular, a qual por sua vez depende dos mecanismos de controle respiratório existentes na mitocôndria, a forte inibição pela ouabaína significa que boa parte do metabolismo energético de uma grande variedade de células é usada para suprir ATP para a $\mathrm{Na}^{+} / \mathrm{K}^{+}$- ATPase (TSAI \& LIN, 2007).

A $\mathrm{Na}^{+} / \mathrm{K}^{+}$-ATPase e a $\mathrm{H}^{+}$-ATPase (anidrase carbônica) são duas proteínas muito estudadas e têm sido consideradas como enzimas-chave no que se refere aos mecanismos de regulação iônica e osmótica envolvidos nos avanços evolucionários que permitiram a transição de crustáceos do meio marinho para o terrestre (TSAI \& LIN, 2007). A Na $/ \mathrm{K}^{+}-A T P a s e$ 
basolateral das brânquias provém força eletroquímica para a tomada de sódio e cloreto, enquanto que a anidrase carbônica do citosol das células brânquias provém $\mathrm{H}^{+}$e $\mathrm{HCO}_{3}^{-}$para a incorporação de sódio e cloreto quando os animais se deparam com um ambiente diluído (CHOU e col., 2002). Como a anidrase carbônica está envolvida tanto na osmorregulação quanto nas trocas gasosas, a inibição de sua atividade pode causar, portanto, desordens tanto respiratórias quanto osmorregulatórias (VITALE e col., 1999; MARTINS e col., 2011).

\section{Metalotioneína}

Metais traço acumulados requerem destoxificação fisiológica, tipicamente pela ligação com grânulos inorgânicos de alta afinidade, os quais frequentemente possuem uma base fosfato, ou se ligam a proteínas com capacidade de destoxificação, como a metalotioneína ou a ferritina (RAINBOW, 1997). Geralmente, considera-se que estas proteínas exercem função primária na homeostase de metais essenciais como cobre e zinco (MOUNEYRAC e col., 2001).

A metalotioneína é uma proteína induzida por diversos metais tóxicos., Está também envolvida no acúmulo e distribuição de cobre e zinco e na atividade de limpeza de radicais livres. Por isso, a metalotioneína é um componente vital tanto para o armazenamento de metais essenciais quanto para o seu seqüestro quando atingem níveis tóxicos, e tem, consequentemente, ganho importância como um biomarcador para organismos expostos a ambientes ricos em metais tóxicos (MINGHETTI e col., 2008).

O cobre absorvido através da difusão celular facilitada se acumula nos invertebrados aquáticos, podendo formar complexos com a metalotioneína, uma proteína quelante. Este acúmulo de cobre nos organismos pode atingir concentrações por unidade de massa mais elevadas que a sua própria concentração na água circundante. De acordo com GOODYEAR \& McNEILL (1999) essas concentrações são frequentemente maiores que aquelas encontradas na água, mas inferiores às concentrações encontradas no sedimento.

Nos animais aquáticos, o primeiro local de dano imediato provocado pela ação tóxica do cobre é as brânquias e a mobilização de proteínas que se ligam ao metal, como a metalotioneína, pode ser um importante fator durante a fase de restauração por meio da destoxificação e posterior armazenamento de metal em tecidos como o hepatopâncreas (GROSELL e col., 1997; CHOWDHURY e col., 2003). 
As metalotioneínas podem transferir cobre para a hemocianina, o pigmento respiratório de crustáceos e de outros invertebrados, assim como podem também regular os níveis de cobre durante o ciclo da muda (BAINY, 2000). As metalotioneínas também se ligam a metais não essenciais, como cádmio e mercúrio, o que evidencia mais uma vez a sua função de seqüestrar e conseqüentemente proteger os organismos contra os efeitos tóxicos dos metais (ROESIJADI, 1992; WU \& CHEN, 2005).

LEGRAS e col. (2000) demonstraram que alterações nas concentrações de metalotioneínas estão relacionadas com alterações nas concentrações das proteínas de modo geral (MOUNEYRAC e col., 2001) e a indução de metalotioneínas pode ser um forte indicativo da existência de um processo de regulação fisiológica (DANG e col., 2009).

\section{Destoxificação}

Crustáceos e outros invertebrados apresentam uma série de mecanismos de destoxificação de metais pesados para reduzir a concentração intracelular destes. O seqüestro de metais em organelas específicas ou a ligação destes a proteínas citoplasmáticas (metalotioneínas) podem ser geneticamente super-reguladas como resposta a elevadas concentrações de xenobióticos celulares (MANDAL e col., 2006).

Os resultados obtidos por VIARENGO e col. (1997) demonstraram que o cobre se acumula nas células da glândula digestiva de mexilhões expostos ao metal (Mytillus galloprovincialis), porém é rapidamente destoxificado e eliminado das células (VIARENGO e col., 1985). Tais respostas podem ocorrer por meio de duas vias: (i) aumento da síntese de Cutioneínas, uma classe de proteínas solúveis com baixo peso molecular e ricas em cisteínas, as quais têm grande afinidade por metais pesados; e (ii) acúmulo do metal em lisossomos e corpos residuais, os quais são subseqüentemente eliminados por exocitose (VIARENGO e col., 1985). 


\section{Homeostase}

A exposição dos organismos a estresses desencadeia uma série de respostas fisiológicas, as quais geram custos e estes, por sua vez, estão embutidos nos processos que permitem o restabelecimento parcial ou total das condições originais a fim de garantir a sobrevivência do organismo. Esses processos incluem dentre tantos outros a reparação de danos celulares, o aumento da quantidade de células para repor células efetoras e para que haja, no caso de exposição a agentes tóxicos, o processo de destoxificação propriamente dito. No longo prazo, as mudanças compensatórias, nas quais se incluem o controle do fluxo metabólico, a indução da supressão de enzimas e a seleção natural das enzimas variantes, fazem parte de um processo mais amplo de competição entre as espécies para que haja continuidade da reprodução e desenvolvimento no ambiente contaminado (HARRIS \& SANTOS, 2000).

Qualquer aumento da concentração total do metal dissolvido no ambiente externo pode provocar um aumento da concentração do íon livre do metal em equilíbrio, e pó conseguinte levar a um aumento da taxa de tomada do metal pela biota (RAINBOW, 1995). Por isso, a regulação da atividade intracelular de cobre é extremamente importante para a manutenção celular (ODERMATT e col., 1993).

Os níveis plasmáticos de cobre são regulados na truta (Oncorkynchus mykiss) (HOGSTRAND e col., 1994). Assim como nos mamíferos, o fígado de peixes é o principal órgão e o mais envolvido na homeostase do cobre, acumulando uma grande proporção do metal absorvido por meio da dieta e da água, além de ser o local de síntese da metalotioneína mais abundante em cobre, a ceruloplasmina, a qual é secretada no sangue e atua como fonte de cobre para órgãos extra hepáticos. Os hepatócitos são o local primário para acúmulo de cobre no fígado e utilizam ao menos uma via para a tomada do metal. Uma destas vias envolve a redução de $\mathrm{Cu}^{2+}$ em $\mathrm{Cu}^{+}$, seguida pela transferência deste através da membrana por um processo clássico mediado por carreadores (FOSSET e col., 2005).

Assim, a sobrevivência dos animais marinhos residentes em ambientes poluídos depende de mecanismos diferentes: (i) limitação da tomada de metal; (ii) aumento dos processos de destoxificação; e (iii) aumento da excreção do metal (MASON \& JENKINS, 1995; LEGRAS e col., 2000). 


\section{RESUMO GERAL}

Recentemente, tem sido reconhecido que a água pode ser ao mesmo tempo uma fonte vital para os organismos e um veículo para eliminação de poluentes. Esse paradoxo pode ser considerado como parte da crise do presente ambiente que está inserida no conflito entre natureza e tecnologia, sendo acompanhado pelo emprego de biomarcadores, que consistem em indicadores bioquímicos e celulares da presença de contaminantes através da análise de fluidos corpóreos bem como células ou tecidos. O principal objetivo deste trabalho foi o de verificar quais os possíveis efeitos do cobre na homeostase do caranguejo de mangue Ucides cordatus expostos ao cobre na água $\left(\mathrm{CuSO}_{4}\right)$ por diferentes períodos de tempo, através de teste agudo com exposição durante $24 \mathrm{~h}$ e $96 \mathrm{~h}$ e teste crônico com duração de 15 dias. Após a exposição dos animais à agua contaminada, estes foram crio-anestesiados pra dessensibilização e então foram retiradas alíquotas de hemolinfa e urina para determinação de concentrações de sódio, potássio, magnésio e cálcio, bem como as concentrações de glicose e lactato, além de brânquias e hepatopâncreas para a dosagem de enzimas como $\mathrm{Na}^{+} / \mathrm{K}^{+}-$ ATPase, anidrase carbônica e a concentração da proteína metalotioneína, não esquecendo o músculo da quela que foi utilizado para determinação da concentração de glicogênio (assim como para o hepatopâncreas). Para complementar o amplo trabalho, foi determinado o transporte de cobre na membrana celular de brânquias e hepatopâncreas, através do qual foi possível verificar que a entrada do cobre pela membrana plasmática pode ocorrer através de diversas vias, podendo ser elas dependentes ou independentes de cálcio, porém é estritamente dependente da concentração de sódio no meio extra e intracelular, demonstrando interação entre transportadores para manutenção da homeostase. Além disso, o cobre se apresenta como um íon competidor com outros cátions como magnésio e potássio, além, claro, de alterar atividades enzimáticas como da $\mathrm{Na}^{+} / \mathrm{K}^{+}$-ATPase e anidrase carbônica. No entanto é válido notar que, principalmente para as brânquias anteriores, que são predominante respiratórias, houve aumento da síntese de metalotioneína, proteína esta induzida na presença de altas concentrações de cobre, que dentre outras funções, é principal componente da hemocianina, pigmento respiratório dos crustáceos. 


\section{ABSTRACT}

Recently, it has been recognized that water can be both a vital source for the organisms and a vehicle for disposal of pollutants. This paradox may be considered as part of the environment crisis that is inserted between nature and technology conflict, accompanied by the use of biomarkers that consists of cellular and biochemical indicators of contamination by analysis of body fluids as well as cells or tissues. The main objective of this study was to determine what the possible effects of copper homeostasis mangrove crab Ucides cordatus exposed to copper in water $\left(\mathrm{CuSO}_{4}\right)$ for different periods of time, by testing acute exposure for $24 \mathrm{~h}$ and $96 \mathrm{~h}$ and chronic test, lasting 15 days. After exposure of the animals to contaminated water, they were cryo-anesthetized for desensitization and then aliquots of haemolymph and urine were collect to determine hemolymph and urine concentration of sodium, potassium, magnesium and calcium, and the concentrations of glucose and lactate as well as gills and hepatopancreas for measure enzymes such as $\mathrm{Na}^{+} / \mathrm{K}^{+}$-ATPase, carbonic anhydrase and metallothionein protein concentration, not forgetting the muscle which was used for the determination of glycogen concentration (as for the hepatopancreas). To complement the extensive study, it was determined copper transport in gills and hepatopancreas epithelial cells, whereby it was verified that the input of copper by plasma membrane can occur through various routes, which can be dependent or independent of calcium, but it is strictly dependent on the sodim concentration in intracellular and extracellular medium, showing interaction between transport proteins for maintaining homeostasis. Furthermore, copper is presented as a competitive with other cations such as magnesium and potassium, in addition of course to alter enzymatic activity as $\mathrm{Na}^{+} / \mathrm{K}^{+}$-ATPase and carbonic anhydrase. However it is worth noting that, especially prior to the anterior gill cells, which are predominant respiratory, that there was increased synthesis of metallothionein, which is a protein induced in the presence of high concentrations of copper, which among other functions, is the main component of hemocyanin, the respiratory pigment crustaceans. 
AHEARN, G. A.; DUERR, J. M.; ZHUANG, Z.; BROWN, R. J.; ASLAMKHAN, A; KILLEBREW, D. A. Ion transport processes of crustacean epithelial cells. Physiol Biochem Zool 72(1): 1-18, 1999.

AHEARN, G.A.; FRANCO, P. Sodium and calcium share the electrogenic $2 \mathrm{Na} / 1 \mathrm{H}$ antiporter in crustacean antennal glands. Am J Physiol 259: F758-767, 1990

AHEARN, G.A.; FRANCO, P. Electrogenic 2Na/1H antiporter in echinoderm gastrointestinal epithelium. J Exp Biol. 158: 495-507, 1991.

AHEARN, G.A. ; FRANCO, P. Calcium transport pathways in brush border membrane vesicles of crustacean antennal glands. Am J Physiol 264: R1206-1213, 1993.

AHEARN, G.A.; MANDAL, P.K.; MANDAL, A. Mechanism of heavy metal sequestration and detoxification in crustaceans: a review. J Comp Physiol B 174: 439-452, 2004.

AHEARN, G. A.; ZHUANG, Z.; DUERR, J.; PENNINGTON, V. Role of the invertebrate electrogenic $2 \mathrm{Na}^{+} / 1 \mathrm{H}^{+}$antiporter in monovalent and divalent cation transport. J Exp Biol 196: 319335, 1994.

AL-MOHANA, S.Y.; NOTT, J.A; LANE, D.J.W. Mitotic E- and secretory $F$ cells in the hepatopancreas of the shrimp Penaeus semisulcatus (Crustacea: Decapoda). J Mar Biol Assoc. UK 65: 901-910, 1985.

AL-MOHANA, S.Y.; NOTT, J.A. R-cells and the digestive cycle in Penaeus semisulcatus (Crustacea: Decapoda). Mar Biol 95: 129-137, 1987.

AL-MOHANA, S.Y.; NOTT, J.A. Functional cytology of the hepatopancreas of Penaeus semisulcatus (Crustacea: Decapoda) during the moult cycle. Mar Biol 101: 535-544, 1989.

ALCORLO, P.; OTERO, M.; CREHUET, M.; BALTANÁS, A.; MONTES, C. The use of the red swamp crayfish (Procambarus clarkii, Girard) as indicator of the bioavailability of heavy metals in environmental monitoring in the River Guadiamar (SW, Spain). The Sci Tot Environ 366(1): 380-390, 2006.

ALMEIDA, J. S.; MELETTI, P. C.; MARTINEZ, C. B. R. Acute effects of sediments taken from an urban stream on physiological and biochemical parameters of the neotropical fish Prochilodus lineatus. Comp Biochem Physiol Part C 140(3-4): 356-363, 2005. 
ALVES, R. R. N.; NISHIDA, A. K.; HERNÁNDEZ, M. I. M. Environmental perception of gatherers of the crab "caranguejo-uçá" (Ucides cordatus, Decapoda, Brachyura) affecting their collection attitudes. J Ethnobiol Ethnomed 1: 10-18, 2005.

AMIARD, J.C.; AMIARD-TRIQUET, C.; BARKA, S.; PELLERIN, J.; RAINBOW, P. S. Metallothioneins in aquatic invertebrates: their role in metal detoxification and their use as biomarkers. Aquat Toxicol, 76(2): 160-202, 2006.

ARREDONDO, M.; NÚÑEZ, M. T. Iron and copper metabolism. Mol Asp Med 26(4-5): 313-327, 2005.

ARONSON, P.S.; NEE, J.; SUHM, M.A. Modifier role of internal hidrogen activating the $\mathrm{Na}^{+}-\mathrm{H}^{+}$ exchanger in renal microvillus membrane vesicles. Nature 299: 161-163, 1982.

BAMBER, S. D.; DEPLEDGE, M.H. Responses of shore crabs to physiological challenges following exposure to selected environmental contaminants. Aquat Toxicol 40: 79-92, 1997.

BAMBANG, Y.;THUET, P.;CHARMANTIER-LURES, M.; TRILLES, J.; CHARMANTIER, G. Effect of copper on survival and osmoregulation of various developmental stages of the shrimp Penaeus japonicus Bate (Crustacea: Decapoda). Aquat Toxicol 33: 125-139, 1995.

BARRON, M., \& ALBEKE, S. Calcium control of zinc uptake in rainbow trout. Aquat Toxicol 50(3): 257-264, 2000.

BATESON, P.; BRADSHAW, E.L. Physiological effects of hunting red deer (Cervus elaphus). Proc Royal Soc B, 264: 1707-1714, 1997.

BAUTISTA, M.N.; LAVILLA-PITOGO, C.R.; SUBOSA, P.F. Aflatoxin B1 contamination of shrimp feeds and its effect on growth and hepatopancreas of pre-adult Penaeus monodon. J Sci Food Agric 65: 5-11, 1994.

BELTRAME, M.O.;DE MARCO, S.G.; MARCOVECCHIO, J.E.;SILVIA, B. The burrowing crab Neohelice granulata as potential bioindicator of heavy metals in estuarine systems of the Atlantic coast of Argentina. Environ Monit Assess 172: 379-389, 2011.

BHAVAN, S.P.; GERALDINE, P. Histopathology of the hepatopancreas and gills of the prawn Macrobrachium malcolmsonii exposed to endosulfan. Aquat Toxicol 50(4): 331-339, 2000. 
BIANCHINI, A.; MARTINS, S.E.G.; BARCAROLLI, F. Mechanism of a acute copper toxicity in euryhaline crustaceans: implications for the biotic ligand model. Int Congr Sci 1275: 189194, 2004.

BIDINOTTO, P.M.; MORAES, G.; ZOUZA, R.H.S. Hepatic glycogen and glucose in eight tropical freshwater teleost fish: a procedure for field determinations of micro samples. B. Tec CEPTA 10: 53-60, 1997.

BHAVAN P.S.; GERALDINE, P. Histopathology of the hepatopancreas and gills of the prawn Macrobrachium malcolmsonii exposed to endosulfan. Aquat Toxicol 50(4): 331-339, 2000.

BJERREGAARD, P.; VISLIE, T. Effect of copper on ion and osmoregulation in the shore crab Carcinus maenas. Mar Biol 91: 69-76, 1986.

BOITEL, F.; TRUCHOT, J.P. Effects of sublethal and lethal copper levels on haemolymph acidbase balance and ion concentrations in the shore crab Carcinus maenas kept in undiluted seawater. Mar Biol 103: 495-501, 1989.

BORGMANN, U. A mechanistic model of copper accumulation in Hyalella azteca. T Sc Tot Environ 219(2-3): 137-145, 1998.

BORKOVIĆ, S. S.; PAVLOVIĆ, S. Z.;KOVACEVIĆ, T. B.;STAJN, A. S.; PETROVIĆ, V. M.; SAICIĆ, Z. S. Antioxidant defence enzyme activities in hepatopancreas, gills and muscle of Spiny cheek crayfish (Orconectes limosus) from the River Danube. Comp Biochem Physiol Part C 147(1): 122-128, 2008.

BOSSUYT, B. T. A.; JANSSEN, C. R. Copper regulation and homeostasis of Daphnia magna and Pseudokirchneriella subcapitata: influence of acclimation. Environ Poll 136(1): 135-44, 2005.

BOUQUEGNEAU, J.M.; GILLES, R. Osmoregulation and pollution of the aquatic emdium. In: Mechanisms of osmoregulation in animals (R. Gilles ed), Wiley, p.563-580, 1979.

BOUSKILL, N. J.; HANDY, R. D.; FORD, T. E.; GALLOWAY, T. S. Differentiating copper and arsenic toxicity using biochemical biomarkers in Asellus aquaticus and Dreissena polymorpha. Ecotox Environ Saf 65(3): 342-9, 2006. 
BÖTTCHER, K.; SIEBERS, D.; BECKER, W.; PETRAUSCH, G. Pysiological role of branchial carbonic anhydrase in the shore crab Carcinus maenas. Mar Biol 110: 337-342, 1991.

BRIX, K.V.; DEFOREST, D.K. Critical review of the use of bioconcentration factors for hazard classification of metals and metal compounds. Paranetrix, Inc. Report 555, 3690-001. Kirkland, WA, 2000.

BROOKS, S. J.; MILLS, C. L. The effect of copper on osmoregulation in the freshwater amphipod. Physiol 135: 527-537, 2003.

BROUWER, M.; HOEXUM-BROUWER, T.; GRATER, W.; ENGHILD, J.J.; THOGERSEN, I.B. The paradigm that all oxygen-respiring eukaryotes have cytosolic CuZn-superoxido dismutase and that Mn-superoxide dismutase is localized to the mitochondria does not aplly to a large group of marine arthropods. Biochem 36: 13381-13388, 1997.

BROUWER, M.;SYRING, R.; BROUWER, T. H. Role of a copper-specific metallothionein of the blue crab , Callinectes sapidus, in copper metabolism associated with degradation and synthesis of hemocyanin, J Inorg Biochem 88: 228-239, 2002.

BRUNET, M.; ARNAUD, J.; MAZZA, J. Gut structure and degestive cellular process in marine crustacea. Oceanogr Mar Biol 32: 335-367, 1994.

BRYAN, G.W. Concentrations of zinc and copper in the tissues of decapod crustaceans. J Mar Biol Assoc UK, 48:303-321, 1968.

BURY, N.R.; GROSELL, M.; GROVER, A K.; WOOD, C. M. ATP-dependent silver transport across the basolateral membrane of rainbow trout gills. Toxicol App Pharmacol 159(1): 1-8, 1999.

BURY, N. R.; WALKER, P.A.; GLOVER, C.N. Nutritive metal uptake in teleost fish. J Exp Biol 206(1):11-23, 2003.

BURY, N. R.; WOOD, C. M. Mechanism of branchial apical silver uptake by rainbow trout is via the proton-coupled $\mathrm{Na}\left({ }^{+}\right)$channel. Am J Physiol 277(2): R1385-91, 1999.

CACECI, T.; NECK, K.F.; LEWIS, D.H. ;SIS, R.F. Ultrastructure of the hepatopancreas of the pacific white shrimp Penaeus vannamei (Crustacea: Decapoda). J Mar Biol Assoc UK, 68: 323$337,1988$. 
CAMPBELL, H.; HANDY, R.D.; NIMMO, M. Copper uptake kinetics across the gills of rainbow trout (Oncorhynchus mykiss) measured using an improved isolated perfused head technique. Aquat Toxicol 46(3-4): 177-190, 1999.

CANLI, M.; FURNESS, R. W. Toxicity of Heavy Metals Dissolved in Sea Water and Influences of Sex and Size on Metal Accumulation and Tissue Distribution in the Norway Lobster Nephrops norvegicus. Mar Environ Res 36: 217-236, 1993.

CASTILHO, P.C.; MARTINS, I.A.; BIANCHINI, A. Gill Na ${ }^{+}, \mathrm{K}^{+}-$ATPase and osmoregulation in the estuarine crab, Chamagnathus granulata Dana, 1851 (Decapoda, Grapsidae). J Exp Biol Ecol 256: 215, 227, 2001.

CHANG, E.S.; CHANG, S.A.; KELLER, R.; REDDY, P.S.; SNYDER,M.; SPEES, J.L. Quantification of stress in lobsters: crustacean hyperglycemic hormone, stress proteins, and gene expression. Am Zool 39: 487-495, 1999.

CHANG, E.S.; KELLER, R.; CHANG, S.A. Quantification of crustacean hyperglycaemic hormone by ELISA in haemolymph of the lobster Homarus americanus following various stresses. Gen Comp Endocr 111: 359-366, 1998.

CHAVEZ-CROOKER, P.; GARRIDO, N.; AHEARN, G. A. Copper transport by lobster hepatopancreatic epithelial cells separated by centrifugal elutriation: measurements with the fluorescent dye Phen Green. J Exp Biol 204( 8): 1433-44, 2001.

CHAVEZ-CROOKER, P.;GARRIDO, N.; AHEARN, G. A. Copper transport by lobster (Homarus americanus) hepatopancreatic mitochondria. J Exp Biol 205(3): 405-13, 2002.

CHAVEZ-CROOKER, P.; GARRIDO, N.; POZO, P.; AHEARN, G. A. Copper transport by lobster (Homarus americanus) hepatopancreatic lysosomes. Comp Biochem Physiol Part C 135: 107-118, 2003a.

CHAVEZ-CROOKER, P.; POZO, P.; CASTRO, H.; DICE, M.S.; BOUTET, I.;IANGUY, A.; MORAGA, D.; AHEARN, G.A. Cellular localization of calcium, heavy metals, and metallothionein in lobster (Homarus americanus) hepatopancreas. Comp Biochem Physiol Part C 136(3): $213-224,2003 b$ 
CHOU, C. L.;PAON, L. A.; MOFFATT, J. D. Metal contaminants for modelling lobster (Homarus americanus) migration patterns in the Inner Bay of Fundy, Atlantic Canada. Mar Poll Bull 44(2): 134-41, 2002.

CHOWDHURY, M. J.; GROSELL, M.; MCDONALD, D. G.; WOOD, C. M. Plasma clearance of cadmium and zinc in non-acclimated and metal-acclimated trout. Aquat Toxicol 64(3): 259-275, 2003.

CHUA, T.E. Coastal acquaculture development and the environment the role of coastal area management. Mar Poll Bull 25:98-103, 1992.

COPELAND, D.E.; FITZJARREL, A.T. The salt absorbing cells in the gills of the blue crab Callinectes sapidus with notes on modified mitochondria. Z. Zellforsch 92: 1-22, 1968.

CORREA JR, J.D.; SILVA, M.R.; SILVA, A.C.B.; LIMA, S.M.A.; MALM, O.; ALLODI, S. Tissue distribution, subcellular localization and endocrine disruption patterns induced by $\mathrm{Cr}$ and $\mathrm{Mn}$ in the crab Ucides cordatus. Aquat Toxicol 73: 139-154, 2002.

COSTLOW, J.D. Effects of carbonic anhydrase inhibitors on shell development and growth of Balanus imporvisus Darwin Physiol Zool 32: 177-189, 1959.

DANG, F.; ZHONG, H.; WANG, W.X. Copper uptake kinetics and regulation in a marine fish after waterborne copper acclimation. Aquat Toxicol 94: 238-244, 2009.

DAVIS, L.E.; BURNETT, A.L. A study of growth and cell differentiation in the hepatopancreas of the crayfish. Dev Biol 10: 122-153, 1964.

DE SCHAMPHELAERE, K.A.C.; FORREZ, I.; DIERCKENS, K.; SORGELOOS, P.; JANSSEN,C .R. Chronic toxicity of dietary copper to Daphnia magna. Aquat Toxicol 81: 409-418, 2007.

DEPLEDGE, M.H. The national basis for the use of biomarkers as ecotoxicological tools. In: Fossi, M.C.; Leonzio, C (eds). Non-destructive biomarkers in vertebrates. Lewis Publishers, Broca Raton, p.261-285, 1993.

DEPLEDGE, M.H.; BJERREGAARD, P. Haemolymph protein composition and copper levels in decapod crustaceans. Helg Meeresunt 43: 207-223, 1989. 
DEPLEDGE, M.H.; RAINBOW, P.S. Models of regulation and accumulation of trace metals in marine invertebrates. Comp Biochem Physiol Part C 97: 1-7, 1990.

DiDONATO, M.; SARKAR, B. Copper transport and its alterations in Menkes and Wilson diseases. Biochem Biophys Acta 1360: 3-16, 1997.

DIJKSTRA, M. BERG, G.J.; WOLTERS, H.; VELD, G.I. SLOOF, M.J.H.; HEYMAN, H.S.A; KUIPERS, F.; VONK, R.J. Adenosine triphosphate-dependent copper transport in human liver. J Hepat 25: 37-42, 1996.

DUBOIS, M.; GILLES, K.A; HAMILTON, J.K.; RIBERS, P.A.; SMITH, F. Colorimetric methods for determination of sugars and substances relates. Ann Chem 28: 350-358, 1956.

DUINKER, J.C.; NOLTING, R.F. Dissolved copper, zinc and cadmium in the Southern Bight of the North Sea. Mar Poll Bull 13: 93-96, 1982.

DUKE, N.C. Mangrove floristics and biogeograph. In: Tropical Mangrove Ecosystems (AI Robertson and DM Alongi (eds). American Geophysical Union, Washinghton DC, USA, p.63-100, 1992.

ELWOOD, R. W.;BARR, S.; PATTERSON, L. Pain and stress in crustaceans? Appl Anim Beh Sci 118(3-4): 128-136, 2009.

ENGEL, D.W.; BROUWER, M. Metallothioneins and metallothionein-like proteins physiological importance. In: R. Gilles Advances in comparative and environmental physiology, New York, Springer-Verlag, v.15, p.53-75, 1989.

EVTUSHENKO, Z.S.; BELCHEVA, N.N.; LUKYANOVA, O.N. Cadmium accumation in organs on the scallop Mlzuhopecten yessoensis II Subcellular distribution of metals and metalbindings proteins. Comp Biochem Physiol Part C 83: 377-383, 1986.

FALK, M.; CHEW, W.; WAITER, J.A.; KWIATKOWSKI, W.; BARCLAY, D.K.; KLASSEN, G.A. Molecular modelling and NMR studies of the caffeine dimmer. Can J Chem 76: 48-56, 1998.

FATEMI, N.; SARKAR, B. Insights into the mechanism of copper transport by the Wilson and Menkes disease copper-transporting ATPases. Inorg Chim Acta 339: 179-187, 2002. 
FENT, K. Ecotoxicological problems associated with contaminated sites. Toxicol Lett 140-141: 353-365, 2003.

FENWICK, J.; WENDELAAR B. S.; FLIK, G. In vivo bafilomycin-sensitive $\mathrm{Na}\left({ }^{+}\right)$uptake in young freshwater fish. J Exp Biol 202(24): 3659-66, 1999.

FERRER, L.; ANDRADE, S.; ASTEASUAIN, R.; MARCOVECCHIO, J. Acute toxicities of four metals on the early life stages of the crab Chasmagnathus granulata from Bahía Blanca estuary, Argentina. Ecotoxicol Environ Saf 65(2): 209-217, 2006.

FINGERMAN, M.; JACKSON, N.C.; NAGABHUSHANAM, R. Hormonally-regulated functions in crustaceans as biomarkers of environmental pollution: review. Comp Biochem Physiol Part C 120: 343-350, 1998

FONTAINE, S. L.; MERCER, J. F. B. Trafficking of the copper-ATPases, ATP7A and ATP7B: Role in copper homeostasis. Arch Biochem Biophy 463: 149-167, 2007.

FOSSET, C.; MCGAW, B. A.; REID, M. D.; McARDLE, H. J. A non-radioactive method for measuring Cu uptake in HepG2 cells. J. Inorg Biochem 99(5): 1018-22, 2005.

FRANSKA, M. Detection of binuclears copper-caffeine complexes under electrospray ionization condition. Eur J Mass Spectro 14: 81-86, 2008.

FREIRE, C. A; ONKEN, H.; McNAMARA, J. C. A structure-function analysis of ion transport in crustacean gills and excretory organs. Comp Biochem Physiol Part A 151(3): 272-304, 2008.

GALHARDI, C.M.; DINIZ, Y.S.; FAINE, L.A.; RODRIGUES, H.G.; BURNEIKO, R.C.; RIBAS, B.O.; NOVELLI, E.L. Toxicity of copper intake: lipid profile, oxidative stress and susceptibility to renal dysfunction. Food Chem Toxicol 42: 2053-2060, 2004.

GALVEZ, F.; WEBB, N.; HOGSTRAND, C.; WOOD, C.M. Zinc binding to the gills of rainbow trout: the effect of long-term exposure to sublethal zinc. J Fish Biol 52: 1089-1104, 1998.

GEERING, K. Topogenic motifs in P ATPases. J. Membr Biol 174: 181-190, 2000. 
GEORGE, S.G.; OLSSON, P.E. Metallothioneins as indicators of trace metal pollution. IN: Kramer, K.J.M. (ed) Biomonitoring of Coastal Waters and Estuarines Critical Review Wiley Press, Boca, Raton, Florida, p 151-171, 1994.

GESAMP (Joint Group of Experts on the Scientific Aspects of Marine Pollution). The health of the oceans. UNEP Regional Seas Reports and Studies no 16, United Nation Environmental Program, 108p, 1982.

GIBSON, R.B.; BARKER, P.L. The decapod hepatopancreas. Oceanogr Mar Biol Annu Rev 17, 285-346, 1979.

GLYNN, A. The influence of zinc on apical uptake of cadmium in the gills and cadmium influx to the circulatory system in zebrafish (Danio rerio). Comp Biochem Physiol Part C 128(2): 165-172, 2001.

GLOWIK, R.M.; GOLOWASCH, J.; KELLER, R.; MARDER, E. D-glucose-sensitive neurosecretoy cells of the crab Cancer borealis and negative feedback regulation of blood glucose level. J Exp Biol 200: 1421-1431, 1997.

GOODYEAR, K.L.; McNIELL, S. Bioaccumulation of heavy metals by aquatic macroinvertebrates of different feeding guilds: a review. Sci Total Environ 229: 1-19, 1999.

GRAY, I.E. A comparative study of the gill area of crabs. Biol Bull 112: 34-42, 1957.

GREENAWAY, P. Calcium balance and moulting in the crustacea. Biol Rev 60: 425-454, 1985.

GRISTEIN, S.; COHEN, S.; GOETZ, J.D.; ROTHSTEIN, A.; GELFAND, E.W. Characterization of the activation of $\mathrm{Na}^{+}-\mathrm{H}^{+}$exchange in lymphocytes by phorbol esters: change in cytoplasmic pH dependence of the antiport. Proc Natl Acad Sci USA 82: 1429-1433, 1985.

GROSELL, M.H.; HOGSTRAND, C.; WOOD, C.M. Cu uptake and turnover in both Cu-acclimated and non-acclimated rainbow trout (Oncorhynchus mykiss). Aquat Toxicol 38: 257-276, 1997.

GROSELL, M.H.; McDONALD, M. D., WOOD, C. M.; WALSH, P. J. Effects of prolonged copper exposure in the marine gulf toadfish (Opsanus beta). I. Hydromineral balance and plasma nitrogenous waste products. Aquat Toxicol 68(3), 249-62, 2004. 
GROSELL, M.H.; WOOD, C. M. Copper uptake across rainbow trout gills: mechanisms of apical entry. J Exp Biol 205(8): 1179-88, 2002.

GUNER, U. Freshwater crayfish Astacus leptodactylus (Eschscholtz, 1823) accumulates and depurates copper. Environ. Monit Assess 133(1-3): 365-369, 2007.

HANDY, R. D. Chronic effects of copper exposure versus endocrine toxicity: two sides of the same toxicological process? Comp Biochem Physiol Part A 135(1): 25-38, 2003.

HANSEN, J.I.; MUSTAFA, T.; DEPLEDGE, M.H. Mechanisms of copper toxicity in the shore crab Carcinus maenas I - Effects on Na,K-ATpase activity, haemolymph electrolyte concentrations and tissue water contents. Mar Biol 114: 253-257, 1992.

HARPER, H.A; RODWELL, V.W.; MAYES, P.A. Manual de Química Fisiológica. 5a ed Atheneu ed, 736p, 1982.

HARTNOLL, R.G. Growth and molting. In: Burggren, W.W.; McMahon, B.R. (eds) Biology of the land crabs. Crambridge University, New York (NY), p.186-210, 1988.

HARRIS, E.D. Copper transport: an overview. Proc Soc Exp Biol Med 196: 130-140, 1991.

HARRIS, R.R.; BAYLISS, D. Gill $\left(\mathrm{Na}^{+} \mathrm{K}^{+}\right)$ATPase in decapod crustaceans: distribution and characteristics in relation to $\mathrm{Na}^{+}$regulation. Comp Biochem Physiol Part A 90: 303-308, 1988.

HARRIS, R. R.;SANTOS, M. C. F. Heavy metal contamination and physiological variability in the Brazilian mangrove crabs Ucides cordatus and Callinectes danae (Crustacea: Decapoda). Mar Biol 137(4): 691-703, 2000.

HAVELAAR, A C.; DE GAST, I. L.; SNIJDERS, S.; BEERENS, C. E.; MANCINI, G. M.; VERHEIJEN, F. W. Characterization of a heavy metal ion transporter in the lysosomal membrane. FEBS letters 436(2), 223-7, 1998.

HAWKINS, A.J.S.; JONES, M.B. Gill area and ventilation in two mud crabs, Helice crassa Dana (Grapsidae) and Macrophtalmus hirtipes (Jacquinot) (Ocypodidae) in relation to habitat. J Exp Mar Biol Ecol 60: 103-118, 1982. 
HEBEL, D. K.; JONES, M. B.; DEPLEDGE, M. H. Responses of Crustaceans to Contaminant Exposure : a Holistic Approach. Est Coast Shelf Sci 44: 177-184, 1997.

HEBEL, D.K.; JONES, M.B.; MOATE, R.M.; DEPLEDGE, M.H. Differing sensitivities of respiratory and osmoregulatory gill tissue of Carcinus maenas (Crustacea: Decapoda) to waterborne copper. Mar Biol 133: 675-681, 1999.

HENRY, R.P. Multiple functions of carbonic anhydrase in the crustacean gill. J Exp Zool 248: 1924, 1988.

HENRY, R.P.; KORMANIK, G.A. Carbonic anhydrase activity and calcium depostion during the molt cycle of the blue crab Callinectes sapidus. J Crust Biol 5: 234-241, 1985.

HOGSTRAND, C.; REID, S.; WOOD, C.M. $\mathrm{Ca}^{2+}$ versus $\mathrm{Zn}^{2+}$ transport in the gills of freshwater rainbow trout and the cost of adaptation to waterborne $\mathrm{Zn}^{2+}$. J Exp Biol 198(2):337-48, 1995.

HOGSTRAND, C.; WEBB, N.; WOOD, C. M. Covariation in regulation of affinity for branchial zinc and calcium uptake in freshwater rainbow trout. J Exp Biol 201(11): 1809-15, 1998.

HOGSTRAND, C.; WILSON, R. W.; POLGAR, D.; WOOD, C. M. Effects of zinc on the kinetics of branchial calcium uptake in freshwater rainbow trout during adaptation to waterborne zinc. J Exp Biol 186: 55-73, 1994.

HOUGHTON, G.; MATTHEWS, R.A. Immunosupression of carp (Cyprinus capro L.) to icthyophthiriasis using the corticosteroid triamcinolone acetonide. Vet Immunol Immunopathol 12: 413-419, 1986.

HU, A.S.L. Glucose metabolism in the crab Hemigrapsus nudus. Arch. Biochem Biophys 75: 387395, 1958.

HUANG, Q.; SHINDO, H. Effects of copper on the activity and kinetics of free and immobilized acid phosphatase. Soil Biol Biochem 32 :1885-1892, 2000.

JENNINGS, J.R.; RAINBOW, P.S. Studies on the uptake of cadmium by the crab Carcinus maenas in the laboratory - I. Accumulation from seawater and a food source. Mar Biol 50: 131139, 1979. 
JORGENSEN, P.L.; PEDERSEN, P.A. Structure function relationships of $\mathrm{Na}^{+}, \mathrm{K}^{+}$ATPase, on $\mathrm{Mg}^{2+}$ binding and energy transduction in Na,K-ATPase. Biochim Biophys Acta 1505: 57-74, 2001.

JONGMAN, E.C.; BIDSTRUP, I.; HEMSWORTH, P.H. Behavioural and physiological measures of welfare of pregnant mare fitted with a novel urine collection device. Appl Anim Behav Sci 93:147-163, 2005.

KAGI, J.H.R.; KOJIMA, Y. Chemistry and biochemistry of metallothionein. In: Kagi, J.H.R.; Kojima, Y (eds). Metallothionein II Birkhauser, Boston, p.25-61, 1987.

KATHIRESAN, K.; BINGHAM, B. L. Biology of Mangroves and Mangrove Ecosystems. Adv Mar Biol 40: 81-251, 2001.

KELLER, R.; ANDREW, E.M. The site of action of the crustacean hyperglycemic hormone. Gen. Comp Endocr 20: 572-578, 1973.

KNOPFEL, M.; SMITH, C.; SOLIÓZ, M. ATP-driven copper transport across the intestinal brush border membrane. Biochem. Biophys. Res Commun 330: 645-652, 2005.

KOZLOWSKI, H.; JANICKA-KLOS, A.; BRASU, J.; GAGGELLI, E.; VALENSIN, D.; VALENSIN, G. Copper, iron and zinc ions homeostasis and their role in neurodegenerative disorders (metal uptake, transport, distribution and regulation). Coordin Chem Rev 253(21-23): 2665-2685, 2009.

KRÅNG, A.S.; EKERHOLM, M. Copper reduced mating behaviour in male shore crabs (Carcinus maenas (L.)). Aquat Toxicol 80(1): 60-69, 2006.

LANGSTON, W.O.; BEBIANNO, M.J.; BURT, G.R. Metal binding strategies in mollusks. In: Langston, W.J.; Bebianno, M. (eds) Metal metabolism in aquatic environments. Chapman and Hall, London, 219-283, 1998.

LAUREN, D.J.; McDONALD, D.G. Effects of copper on branchial ionregulation in the rainbow trout Salmo gairdneri Richardson - modulation by water hardness and pH. J Comp Phsyiol B 155: 635-644, 1985. 
LAUREN, D.J.; McDONALD, D.G. Influence of water hardness, $\mathrm{pH}$, and alkalinity on the mechanisms of copper toxicity in juvenile rainbow trout, Salmo gairdneri. Can J Fish Aquat Sci 43:1488-1496, 1986.

LAWSON, S.L.; JONES, M.B.; MOATE, R.M. Effect of copper on the ultrastructure of the gill epithelium of Carcinus maenas (Decapoda: Brachyura). Mar Poll Bull 31: 63-72, 1995.

LEGRAS, S.; MOUNEYRAC, C.; AMIARD, J.C.; AMIARD-TRIQUET, C.; RAINBOW, P. Changes in metallothionein concentrations in response to variation in natural factors (salinity, sex, weight) and metal contamination in crabs from a metal-rich estuary. J Exp Mar Biol Ecol 246(2): 259-279, 2000.

LI, J.; QUABIUS, E. S.; BONGA, S. E. W.; FLIK, G. Effects of water-borne copper on branchial chloride cells and $\mathrm{Na}^{+} / \mathrm{K}^{+}$-ATPase activities in Mozambique tilapia (Oreochromis mossambicus). Aquat Toxicol 43: 1-11, 1998.

LI, T.; ROER, R.; VANA, M.; PATE, S.; CHECK, J. Gill Area, Permeability and $\mathrm{Na}^{+}, \mathrm{K}^{+}-$ATPase Activity as a Function of Size and Salinity in the Blue Crab, Callinectes sapidus. J Exp Zool 305A: 233-245, 2006.

LI, N.; ZHAO, Y.; YANG, J. Impact of waterborne copper on the structure of gills and hepatopancreas and its impact on the content of metallothionein in juvenile giant freshwater prawn Macrobrachium rosenbergii (Crustacea: Decapoda). Arch Environ Contam Toxicol 52(1): 73-79, 2007.

LI, N.; ZHAO, Y.; YANG, J. Effects of water-borne copper on digestive and metabolic enzymes of the giant freshwater prawn Macrobrachium rosenbergii. Arch Environ Contam Toxicol 55(1): 86-93, 2008.

LIN, H.; RANDALL, D. J. $\mathrm{H}^{+}$-ATPase activity in crude homogenates of fish gill tissue : inhibitor sensitivity and environmental and hormonal regulation. J Exp Biol 180: 163-174, 1993.

LOIZZI, R.F. Interpretation of crayfish hepatopancreatic functions based on final structural analysis of epithelial cells lines and muscle network. Z Zellforsch 113: 420-440, 1971.

LONNERDAL, B. Bioavailability of copper. Am J Clin Nutr 63: 821S - 829S, 1996. 
LORENZON, S.; EDOMI, P.; GIULIANINI, P.G.; METTULIO, R.; FERRERO, E.A. Role of biogenic amine and $\mathrm{CHH}$ in the crustacean hyperglycemic stress responde. J Exp Biol 208: 33413347, 2005.

LORENZON, S.; FRANCESE, M.; FERRERO, E.A. Heavy metal toxicity and differential effects on the hypeglycemic stress response in the shrimp Palaemon elegans. Arch Environ Contam Toxicol 39: 167-176, 2000.

LUCU, C. Ionic regulatory mechanisms in crustacean gill epithelia. Comp Biochem Physiol Part A 97: 297-306, 1990.

LUCU, C; DEVESCOVI, M.; SKARAMUCA, B.; KOZUL, V. Gill Na,K-ATPase in the spiny lobster Palinurus elephas and other marine osmoconformers. Adaptiveness of enzymes from osmoconformity to hyperregulation. J Exp Mar Biol Ecol 246(2):163-178, 2000.

LUCU, C;PAVICIĆ, J.; IVANKOVIĆ, D.; PAVICIĆ-HAMER, D.; NAJDEK, M. Changes in Na+/K+ATPase activity, unsaturated fatty acids and metallothioneins in gills of the shore crab Carcinus aestuarii after dilute seawater acclimation. Comp Biochem Physiol Part A 149(4): 362-72, 2008.

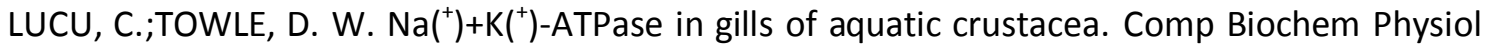
Part A 135(2): 195-214, 2003.

LUOMA, S.N.; RAINBOW, P.S. Why is metal bioaccumulation so variable? Biodynamics s a unifying concept. Environ Sci Tech, 39: 1921-1931, 2005.

LÜSCHEN,W.; WILLING, A.; JARUS, P.P. The role of biogenic amines in the control of blood glucose level in the decapod crustacean, Carcinus maenas (L.). Comp Biochem Physiol Part C 105: 291-296, 1993.

MAAZOUZI, C.; MASSON, G.; IZQUIERDO, M. S.; PIHAN, J.C. Chronic copper exposure and fatty acid composition of the amphipod Dikerogammarus villosus: results from a field study. Environ Poll, 156(1): 221-226, 2008.

MACIEL, J.E.S.; SOUZA, F.; VALLE, S.; KUCHARSKI, L.C.; SILVA, R.S.M. Lactate metabolism in the muscle of crab Chasmagnathus granulatus during hypoxia and post-hypoxia recovery. Comp Biochem Physiol Part A 151: 61-65, 2008. 
MACKEN, A.;GILTRAP, M.; RYALL, K.; FOLEY, B.; McGOVERN, E.; McHUGH, B.; DAVOREN, M. A test battery approach to the ecotoxicological evaluation of cadmium and copper employing a battery of marine bioassays. Ecotoxicol 18(4): 470-480, 2009.

MAGES, M.; WOELFL, S.; TUMPLING, W. A method for trace element determination of single Daphnia specimens using total reflection X-ray fluorescence spectrometry, Spectro Acta Part B, 56: 2209-2217, 2001.

MANDAL, P. K.; MANDAL, A.; AHEARN, G. A. Differential physiological expression of the invertebrate $2 \mathrm{Na}^{+} / 1 \mathrm{H}^{+}$antiporter in single epithelial cell type suspensions of lobster hepatopancreas. J Exp Zool 297A(1): 32-44, 2003.

MANDAL, P. K.; MANDAL, A.; AHEARN, G. A. ${ }^{65} \mathrm{Zn}^{+}$Transport by Lobster Hepatopancreatic Lysosomal Membrane Vesicles. J Exp Zool 305A: 203-214, 2006.

MARIGOMEZ, I.; SOTO, M.; CARAJAVELLE, M.P.; ANGULO, E.; GIAMBERINI, L. Cellular and subcellular distribution of metals in molluscs. Microsc Res Tech 56: 358-392, 2002.

MARTÍN-DÍAZ, M. L.; VILLENA-LINCOLN, A.; BAMBER, S.; BLASCO, J.; DELVALLS, T. A. An integrated approach using bioaccumulation and biomarker measurements in female shore crab, Carcinus maenas. Chemosp 58(5): 615-626, 2005.

MARTINEZ, C. B.; ALVARES, E. P.; HARRIS, R. R.; SANTOS, M. C. A morphological study on posterior gills of the mangrove crab Ucides cordatus. Tissue \& cell 31(3): 380-9, 1999.

MARTINS, C. D. M. G.; BARCAROLLI, I. F.; DE MENEZES, E. J.; GIACOMIN, M. M.; WOOD, C. M.; \& BIANCHINI, A. Acute toxicity, accumulation and tissue distribution of copper in the blue crab Callinectes sapidus acclimated to different salinities: in vivo and in vitro studies. Aquat Toxicol 101(1): 88-99, 2011.

MASON, A.Z.; JENKINS, K.D. Metal detoxification in aquatic organisms. In: Tessier, A.; Turner. D.R. (eds). Metal speciation and bioavailability in aquatic systems. John Wiley \& sons, New York, NY, 479-608, 1995.

MASUI, D. C. Gill $\left(\mathrm{Na}^{+}, \mathrm{K}^{+}\right)$-ATPase from the blue crab Callinectes danae: modulation of $\mathrm{K}^{+}$phosphatase activity by potassium and ammonium ions. Comp. Biochem Phsyiol Part B, 134(4): 631-640, 2003. 
MASUI, D. C.; FURRIEL, R. P. M.; SILVA, E. C. C.; MANTELATTO, F. L. M.; MCNAMARA, J. C.; BARRABIN, H.; SCOFANO, H. M. Gill microsomal $\left(\mathrm{Na}^{+}, \mathrm{K}^{+}\right)$-ATPase from the blue crab Callinectes danae: Interactions at cationic sites. Inter J Biochem Cell Biol 37(12): 2521-35, 2005.

MATSUO, A.Y.; WOOD, C.M.; VAL, A.L. Effects of copper and cadmium on ion transport and gill metal binding in the Amazonian-teleost tambaqui (Colossoma macropomum) in extremely soft water. Aquat Toxicol 74(4): 351-364, 2005.

McDONALD, D.G.; WOOD, C.M. Branchial mechanisms of acclimation to metals in freshwater fish. In: Cliff Rankin, J.; Junsen, F.B. (ed) Fish Ecophysiology. Chapman \& Hall, London, New York, pp 297-321, 1993.

McGEER, J.C.; SZEBEDINSZKY, C.; McDONALD D.G.; WOOD, C.M. Effects of chronic sublethal exposure to waterborne $\mathrm{Cu}, \mathrm{Cd}$ or $\mathrm{Zn}$ in rainbow trout 2: tissue specific metal accumulation. Aquat Toxicol 50(3): 245-256, 2000.

MERRIT, J.E.; ARMSTRONG, W.P.; BENCHAM, C.D.; HALLAN, T.J.; JACOB, R.; JAXA-CHAMIEC, A.; LEIGH, B.K.; MCCARTHY, J.A; MORRES, K.E.;, RINK, J.J. SK\&F96365, a novel inhibition of receptor-mediated calcim entry. Biochem 271: 515-522, 1990.

MICHELI, F.; GHERARDI, F.; VANNINI, M. Feeding and burrowing ecology of two East African mangrove crabs. Mar Biol 111(2): 247-254, 1991.

MINGHETTI, M.; LEAVER, M. J.; CARPENÈ, E.; GEORGE, S. G. Copper transporter 1, metallothionein and glutathione reductase genes are differentially expressed in tissues of sea bream (Sparus aurata) after exposure to dietary or waterborne copper. Comp Biochem Physiol Part C 147(4): 450-459, 2008.

MONSERRAT, J. M.; MARTíNEZ, P. E.; GERACITANO, L. A; AMADO, L. L.; MARTINS, C. M. G.; PINHO, G. L. L.; CHAVES, I. S.; FERREIRA-CRAVO, M.; VENTURA-LIMA, J.; BIANCHINI, A. Pollution biomarkers in estuarine animals: critical review and new perspectives. Comp Biochem Physiol Part C 146(1-2): 221-234, 2006.

MONTEIRO, S. M.; MANCERA, J. M.; FONTAÍNHAS-FERNANDES, A.; SOUSA, M. Copper induced alterations of biochemical parameters in the gill and plasma of Oreochromis niloticus. Comp Biochem Physiol Part C 141(4): 375-383, 2005. 
MORALES-HERNANDEZ, F.; SOTO-JIMENEZ, M. F.; PAEZ-OSUNA, F. Heavy Metals in Sediments and Lobster (Panulirus gracilis) from the Discharge Area of the Submarine Sewage Outfall in Mazatlan Bay (SE Gulf of California). Arch Environ Contam Toxicol 46(4): 485-491, 2004.

MORRIS, A.W. The chemistry of the Severn Estuary and Bristol Channel. Mar Poll Bull 15: 5761, 1984.

MORRIT, D.; SPICER, J.I. A brief re-examination of the function and regulation of extracellular magnesium and its relationship to activity in crustacean arthropods. Comp Biochem Physiol Part A 106: 19-23, 1993.

MOUNEYRAC, C.; AMIARD-TRIQUET, C.; AMIARD, J. C.; RAINBOW, P. S. Comparison of metallothionein concentrations and tissue distribution of trace metals in crabs (Pachygrapsus marmoratus) from a metal-rich estuary, in and out of the reproductive season. Comp Biochem Physiol Part C 129(3): 193-209, 2001.

NAKATANI, R.E. Biological responses of rainbow trout Salmo gairdneri ingesting zinc-65. Disposal of Radioactive Wastes into Seas, Oceans and Surface waters. Int Atom En Agency, Vienna, p.809-823, 1966.

NELSON, D.L.; COX, M.M. Princípios de Bioquímica de Lehninger. 5a ed, Artmed, 1273p, 2011.

NIEBOER, E.; RICHARDSON, D.H.S. The replacement of the nondescript term "heavy metals" by a biologically and chemically significant classification of metal ions. Environ Poll 1: 326, 1980.

NIYOGI, S.;WOOD, C. M. Interaction between dietary calcium supplementation and chronic waterborne zinc exposure in juvenile rainbow trout, Oncorhynchus mykiss. Comp. Biochem Physiol Part C 143(1): 94-102, 2006.

NONNOTTE, L.; BOITEL, F.; TRUCHOT, J.P. Waterborne copper causes gill damage and haemolymph hypoxia in the shore crab Carcinus maenas. Can J Zool 71: 1569-1576, 1993.

NUDI, A.H.; HADDAD, A.; WAGENER, A.L.R.; FRANCIONI, E.; SCOFIELD, A.L.; SETTE, C. B.; VEIGA, A. Validation of Ucides cordatus as a bioindicator of oil contamination and bioavailability 
in mangroves by evaluating sediment and crab PAH records. Environ Intern 33: 315-327, 2007.

O'CONNOR, J. M.; HUGGETT, R. J. Aquatic pollution problems, North Atlantic coast, including Chesapeake Bay. Aquat Toxicol 11(1-2): 163-190, 1988.

ODERMATT, A; SUTER, H.; KRAPF, R.; SOLIOZ, M. Primary structure of two P-type ATPases involved in copper homeostasis in Enterococcus hirae. J Biol Chem 268(17): 12775-12779, 1993.

OGRA, Y.; AOYAMA, M.; SUZUKI, K. T. Protective role of metallothionein against copper depletion. Arch. Biochem Biophys 451(2), 112-118, 2006.

ONKEN, H.; PUTZZENLECHNER, M. A V-ATPase drives active, eletrogenic and $\mathrm{Na}^{+}$dependent $\mathrm{Cl}^{-}$absorption across the gills of Eriocheir sinensis . J Exp Biol 198: 767-774, 1995.

ONKEN, H.; TRESGUERRES, M.; LUQUET, C.M. Active NaCl absorption across posterior gills of hyperosmoregulating Chamasgnathus granulatus. J Exp Biol 206: 1017-1023, 2003.

PÁEZ-OSUnA, F.; PÉREZ-GONZÁleZ, R.; IZAGUIRRE-FIERRO, G.; ZAZUETA-PADILLA, H. M.; FLORES-CAMPAÑA, L. M. Trace metal concentrations and their distribution in the lobster Panulirus inflatus (Bouvier, 1895) from the Mexican Pacific coast. Environ Poll 90(2): 163-170, 1995.

PÁEZ-OSUNA, F.; TRON-MEYEN, L. Concentration and distribution of heavy metal in tissues of wild and farmed shrimp Penaues vannamei from the Northwest coast of Mexico. Environ Int 22: 443-450, 1996.

PAGANINI, C.L.; SOUZA,M.M.; BIANCHINI, A. Gill ion transport and copper accumulation in the blue crab Callinectes sapidus. Comp Biochem Phsyiol Part C 148: 461-465, 2008.

PAGANINI, C. L.; BIANCHINI, A. Copper accumulation and toxicity in isolated cells from gills and hepatopancreas of the blue crab (Callinectes sapidus). Environ Toxicol Chem/ SETAC, 28(6): 1200-1205, 2009.

PEDERSEN, T. V.; BJERREGAARD, P. Calcium and Cadmium Fluxes Across the Gills of the Shore Crab , Carcinus maenas. Mar Poll Bull, 31: 73-77, 1995. 
PEDERSON, S.N.; LUNDEBYE, A.K. Metallothionein and stress protein levels in shore crab (Carcinus maenas) along a trace metal gradient in the Fal Estuary (UK). Mar Environ Res 42(1-4): 241-246, 1996.

PEDERSON, S.N.; LUNDEBYE, A.K.; DEPLEDGE, .H. Field application of metallothionein and stress protein biomarkers in the shore crab Carcinus maenas exposed to trace metal. Aquat Toxicol 37: 183-200, 1997.

PERALES-VELA, H.V.; PEÑA-CASTRO, J.M.; CAÑIZARES-VILLANUEVA, R.O. Heavy metal detoxification in eukaryotic microalgae (review). Chemosp 64: 1-10, 2006.

PERRY, S.F.; FLICK, G. Characterization of branchial transepithelial calcium fluxes in freshwater rainbow trout, Salmo gairdneri. Am J Physiol 23: R491-498, 1988.

PEQUEUX, A. Osmotic regulation in crustaceans. J Crust Biol 15: 1-60, 1995.

PHILIP, A.; MACDONALD, A.L.; WATT, P.W. Lactate- a signal corrdinating cells and systemic function. J Exp Biol 208: 4561-4575, 2005.

PILLER, S.; HENRY, R..; DOCLLER, J.; KRAUS, D. A comparison of the gill physiology of two euryhaline crab species, Callinectes sapidus and Carcinus similis: energy production, transport-related enzymes and osmoregulation as a function of acclimation salinity. $J$ Exp Biol 198: 349-358, 1995.

PINHEIRO, M.A.A.; SILVA, P.P.G.; DUARTE, L.F.A.; ALMEIDA, A.A.; ZANOTTO, F.P. Accumulation of six metals in the mangrove crab Ucides cordatus (Crustacea: Ucididae) and its food source, the red mangrove Rhysophora mangle (Angiosperma: Khizophoraceae). Ecotox Environ Saf 81: 114-121, 2012.

PINHO, G. L. L.; PEDROSO, M. S.; RODRIGUES, S. C.; SOUZA, S. S. D.; BIANCHINI, A. Physiological effects of copper in the euryhaline copepod Acartia tonsa: waterborne versus waterborne plus dietborne exposure. Aquat Toxic 84(1): 62-70, 2007.

PUIG, S.;THIELE, D. J. Molecular mechanisms of copper uptake and distribution. Cur Opin Chem Biol 6(2): 171-80, 2002.

RAINBOW, P.S. Accumulation of $\mathrm{Zn}, \mathrm{Cu}$ and $\mathrm{Cd}$ by crabs and barnacles. Est Coast Shelf Sci 21: 669-686, 1985. 
RAINBOW, P.S. The significance of trace metal concentrations in decapods. Symp Zoll Soc Lond 59: 291-313, 1988.

RAINBOW, P. S. Physiology, physicochemistry and metal uptake-A crustacean perspective. Mar Poll Bull 31(1-3): 55-59, 1995.

RAINBOW, P S. Ecophysiology of Trace Metal Uptake in Crustaceans. Est Coast Shelf Sci 44(2): 169-175, 1997.

RAINBOW, P.S. Phylogeny of trace metal accumulation in crustaceans. In: Langston, W.J.; Bebianno, M.J. (eds). Metal metabolism in aquatic environments. Chapman \& Hall, London, p. 285-319, 1998

RAINBOW, P.S. Ecophysiology and trace metal uptake in crabs and other crustaceans. Comp Biochem Physiol Part A 126 : S1-S163, 2000.

RAINBOW, P. S. Trace metal concentrations in aquatic invertebrates: why and so what ? Environ Poll 120: 497-507, 2002.

RAINBOW, P. S. Trace metal bioaccumulation: models, metabolic availability and toxicity. Environ Intern 33(4): 576-582, 2007.

RAINBOW, P.S.; BLACK, W.H. Cadmium, zinc and the uptake of calcium by two crabs, Carcinus maenas and Eriocheir sinensis. Aquat Toxicol 72: 45-65, 2005.

RAINBOW, P.S.; DALLINGER, R. Metal uptake, regulation and excretion in freshwater invertebrates. In: Ecotoxicology of metals in invertebrates (R. Dallinger \& P.S. Rainbow, eds),Lewis Publishers, Chelsea, USA, p.119-131, 1993.

RAINBOW, P.S.; WHITE, S.L. Comparative strategies of heavy metal accumulation by crustaceans. Zinc, copper and cadmium in a decapod, an amphipod and a barnacle. Hydrobiol 174: 245-262, 1989.

RASMUSSEN, A.D.; KRAG, A.; BJeRREGAARD, P.; WEeKS, J.M.; DePledGE, M.H. The effects of trace metals on the apparent water permeability of the shore crab Carcinus maenas (L.) and the brown shrimp Crangon crangon (L.). Mar Poll Bull 31: 60-62, 1995. 
REBELO, M.; RODRIGUEZ, E. M.; SANTOS, E. A.; ANSALDO, M. Histopathological changes in gills of the estuarine crab Chasmagnathus granulata (Crustacea-Decapoda) following acute exposure to ammonia. Comp Biochem Physiol Part C 125(2): 157-164, 2000.

REDDY,P.S.; DEVI, M.; SAROJINI, R.; NAGABHUSHAMAM, R.; FINGERMAN, M. Cadmium chloride induced hyperglycemia in the red swamp crayfish Procambarus clarki: possible role of crustacean hyperglycemic hormone. Comp Biochem Physiol Part C 107: 57-61, 1994.

RIBEIRO, A. C. F.; SIMÕES, S. M. N.; LOBO, V. M. M.; VALENTE, A. J. M.; ESTESO, M. A. Interaction between copper chloride and caffeine as seen by diffusion at $25^{\circ} \mathrm{C}$ and $37^{\circ} \mathrm{C}$. Food Chem 118(3): 847-850, 2010.

RINDERHAGEN, M.; RITTERHOFF, J.; ZAUKI, G.P. Crustaceans as bioindicators. Biomon Poll 9: 161-194, 2000.

RIVAIL, D.M.; LAMOTTE, M.; DONARD, O.F.X.; SORIANO-SIERRA, E.J.; ROBERT, M. Metal contamination in surface sediments of mangroves, lagoons and southern Bay in Florianopolis Island. Environ Tecn 17(10): 1035-1046, 1996.

RODRIGUEZ, E.M.; MEDESANI, D.A.; FINGERMAN, M. Endocrine disruption in crustaceans due to pollutants: a review. Comp Biochem Physiol Part A 146: 661-671, 2007.

ROESIJADI, G. Metallothioneins in metal regulation and toxicity in aquatic animals. Aquat Toxicol 22: 81-113, 1992.

ROGERS, J. T. Characterization of branchial lead-calcium interaction in the freshwater rainbow trout Oncorhynchus mykiss. J Exp Biol 207(5): 813-825, 2004.

ROMANO, N.; ZENG, C. Ontogenetic changes in tolerance to acute ammonia exposure and associated gill histological alterations during early juvenile development of the blue swimmer crab, Portunus pelagicus. Aquacult 266(1-4): 246-254, 2007.

ROSS, P.S.; DE SWART, R.L.; VAN LOVEREN, H.; OSTERHAUS, A.D.M.E.; VOS, J.G. The immunotoxicity of environmental contaminants to marine wildlife: a review. Ann Rev Fish Dis 6: 151-165, 1996. 
RTAL, A.; NONNOTTE, L.; TRUCHOT, J. P. Detoxification of exogenous copper by binding to hemolymph proteins in the shore crab , Carcinus maenas. Aquat Toxicol 36: 239-252, 1996.

RTAL, A.; TRUCHOT, J.P. Haemolymph transport and tissue accumulation ox exogenous copper in the shore crab, Carcinus maenas. Mar Poll Bull 32(11): 802-811, 1996.

SÁ, M.G.; VALENTI, W.C.; ZANOTTO, F.P. Dietary copper absorption and excretion in three semi-terrestrial grapsoid crabs with different levels of terrestrial adaptation. Comp Biochem Phsyiol Part C 148: 112-116, 2008.

SÁ, M.G.; AHEARN, G.A.; ZANOTTO, F.P. Zn transport by isolated cells of the american lobster Homarus americanus. J Comp Physiol B 179: 605-615, 2009.

SÁ, M.G.BLOTA-BAPTISTA, B.; FARAH, L.; PISANI, V.P.; ZANOTTO, F.P. Calcium transport and homeostasis in gill cells of a freshwater crab Dilocarcinus pagei. J Comp Physiol B 180: 313-321, 2010.

SABATINI, S. E.; CHAUFAN, G.; JUÁREZ, A. B.; COALOVA, I.; BIANCHI, L.: EPPIS, M. R.; RÍOS DE MOLINA, M. D. C. Dietary copper effects in the estuarine crab, Neohelice (Chasmagnathus) granulata, maintained at two different salinities. Comp Biochem Physiol Part C 150(4): 521-527, 2009.

SANTOS, M.C.F.; SALOMÃO, L.C. Haemolymph osmotic and ionic compositions in the gecarcinid crab Ucides cordatus. Comp Biochem Physiol Part A 81: 581-583, 1985.

SANTOS, E.A.; KELLER, R. Regulation and circulating levels of the crustacean hyperglycemic hormone: evidence for a dual feedback control system. J Comp Physiol B 163: 374-379, 1993.

SCHIMIDT-NIELSEN, N. Fisiologia Animal - Adaptação e Meio Ambiente. 5ạed, Santos Livraria Ed, 611p, 2002.

SEDLMEIER, D. Mode of action of the crustacean hyperglycemic hormone. Am Zool 25: 223232, 1985.

SEDLMEIER, D.; KELLER, R. The mode of action of the crustacean neurosecretory hyperglycemic hormone. I. Involvement of cyclic nucleotides. Gen Comp Endocr 45: 82-90, 1981. 
SHINGLES, R.; WIMMERS, L. E.; MCCARTY, R. E. Copper Transport Across Pea Thylakoid Membranes. Plant Physiol 1: 145-151, 2004.

SINGH, R. K.;CHAVAN, S. L.; SAPKALE, P. H. Heavy metal concentrations in water, sediments and body tissues of red worm (Tubifex spp.) collected from natural habitats in Mumbai, India. Environ Monit Assess 129(1-3): 471-81, 2007.

SIMKISS, K.; TAYLOR, M. MEtal fluxes across the membranes of aquatic organisms. CRC Crit Revi Aquat Sci 1: 173-188, 1989.

SKAGGS, H. S.; HENRY, R. P. Inhibition of carbonic anhydrase in the gills of two euryhaline crabs, Callinectes sapidus and Carcinus maenas, by heavy metals. Comp Biochem Physiol Part C 133(4): 605-612, 2002.

SKOU, J.C. Further investigations on a $\mathrm{Mg}^{2+}+\mathrm{Na}^{+}$actvated adenositetriphosphate, possibly related to the active, linked transport of $\mathrm{Na}^{+}$and $\mathrm{K}^{+}$across the nerve membrane. Biochim Biophys Acta 42: 6-23, 1960.

SOEGIANTO, A.; CHARMANTIER-DAURES, M.; TRILLES, J.P.; CHARMANTIER, G. Impact of cadmium on the structure of gills and epipodites of the shrimp Penaeus japonicus. Aquat Liv Res 12(1): 57-70, 1999.

SOLIOZ, M.; ODERMATT, A.; KRAPF, R. Copper pumping ATPases: common concepts in bacteria and man. FEBS Lett 346: 44-47, 1994.

SPICER, J. I.; MORRITT, D.; MALTBY, L. Effect of water-borne zinc on osmoregulation in the freshwater amphipod Gammarus pulex (L.) from populations that differ in their sensitivity to metal stress. Funct Ecol 12(2): 242-247, 1998.

SPICER, J.I.; WEBER, R.E. Respiratory impariment in crustaceans and molluscs due to exposure to heavy metals. Comp Biochem Physiol Part C 100: 339-342, 1991.

SPICER, J.I.; WEBER, R.E. Respiratory impairment by waterborne copper and zinc in the edible crab Cancer pagurus (L.) (Crustacea: Decapoda) during hypoxic exposure. Mar Biol 112: 429-435, 1992.

SPIRO, M.; GRANDORO, D.M.; PRICE, W.E.P. Protonation constant of caffeine in aqueous solution. J Chem Soc - Faraday Trans 85(12): 4259-4267, 1989. 
SPRY, D.J.; WOOD, C.M. A kinetic method for the measurement of zinc influx in vivo in the rainbow trut and the effects of waterborne calcium on fluxes rates. J Exp Biol 142: 425446, 1989.

SRIVASTAVA, D.K. Comparative effects of copper, cadmium and mercury on tissue glycogen of the catfish Heteropneustes fossilis (BLOCH). Toxicol Letters 11: 135-139, 1982.

STAGGS, R.; GOKSOYR, A.; ROGERS, G. Changes in brancial Na/K-ATPase metallothionein and P450 1A1 in dab Limanda limanda in the German Bight: indicators of sediment contamination. Mar Ecol Progr Ser 91: 105-115, 1992.

STARR, C.; TAGGART, R.; EVERS,C.; STARR, L. Biologia: Unidade e Diversidade da Vida. Tradução da 12a ed, vols 1,2 e 3. CEngage Learning, 2012.

STENTIFORD, G.D.; CHANG, E.S.; CHANG, S.A.; NEIL, D.M. Carbohydrate dynamics and the crustacean hyperglycemic hormone $(\mathrm{CHH})$ : effects of parasitic infection in Norway lobster Nephrops norvegicus. Gen Comp Endocr 121: 13-22, 2001.

STENTIFORD, G. D.; FEIST, S. W. A histopathological survey of shore crab (Carcinus maenas) and brown shrimp (Crangon crangon) from six estuaries in the United Kingdom. J Inv Pathol 88(2): 136-146, 2005.

STERNLEIB, I.; GOLDFISCHER, S. Heavy metal in lysosomes. In: Lysosomes in biology and pathology (Dengle, J.T.; DEan R.T. eds). North Holland/American Elsevier, p.185-200, 1976.

TAM, N.F.Y.; WONG, Y.S. Accumulation and distribution of heavy metals in a simulated mangrove system treated with sewage. Hydrobiol 352(1-3): 67-75, 1997.

TAM, N.F.Y.; YAO, M.W.Y. Normalization and heavy metal contamination in mangrove sediments. Sci Tot Environ 216(1-2): 33-39, 1998.

TAYLOR, H.H.; TAYLOR, E.W. Gills and lungs: the exchange of gases and ions. In: Harrison, F.W.; Humes, A.G. (eds) Microscopic anatomy of invertebrates. Wiley-Liss, NY, v.10, p.203-293, 1992.

THOMPSON, J.A.J; COSSON, R.P. An improved electrochemical method for the quantification of metallothionein in marine organisms. Mar Environ Res 11: 137-152, 1984. 
TORREBLANCA, A.; DEL RAMO, J.; DIAZ-MAYANS, J. Effects of cádmium on the biochemical composition of the freshwater crayfish Procambarus clarkia (Girard, 1852). Bull Environ Contam Toxicolo 47: 933-938, 1991.

TORREBLANCA, A.; DEL RAMO, J.; DIAZ-MAYANS, J. Changes in biochemical composition of gills, hepatopancreas and muscle of the red crayfish Procambarus clarkia (Girard) after sublethal exposure to mercury. Comp Biochem Physiol Part C 102: 247-252, 1992.

TOULLEC, J. Y. Crustacean primary cell culture: A technical approach. Meth Cell Sci 21(4): 193198, 1999.

TOWLE, D.W.; WEIHRAUCH, D. Osmoregulation by gills of euryhaline crabs: molecular analysis of transporters. Am Zool 41: 770-780, 2001.

TRUCHOT, L.P. Respiration and ionic regulation in invertebrates exposed to both water and air. Ann Rev Physiol 52: 61-76, 1990.

TSAI, J.R.; LIN, H.C. V-type $\mathrm{H}^{+}$-ATPase and $\mathrm{Na}^{+}, \mathrm{K}^{+}$-ATPase in the gills of 13 euryhaline crabs during salinity acclimation. J Exp Biol 10(4): 620-627, 2007.

UAUY, R.; OLIVARES, M.; GONZALEZ, M. Essentiality of copper in humans. Am J Clin Nutr 67: 952S - 959S, 1998.

VAN WELL, P.B. Hepatopancreas? Comp Biochem Physiol Part A 47: 1-9, 1974.

VIARENGO, A. Biochemical effects of trace metals. Mar Poll Bull 16: 153-158, 1985.

VIARENGO, A. Heavy metals in marine invertebrates: mechanisms of regulation and toxicity at the cellular level. Crit Rev Aquat Sci 1: 295-317, 1989.

VIARENGO, A.; NOTT, J.A. Mechanisms of heavy metal cation homeostasis in marine invertebrates. Comp Biochem PHysiol Part C 104(3): 355-372, 1993.

VIARENGO, A.; PONZANO, E.; DONDEROB, F.; FABBRIH, R. A Simple Spectrophotometric Method for Metallothionein Evaluation in Marine Organisms: an Application to Mediterranean and Antarctic Molluscs. Mar Environ Res 44(1): 69-84, 1997. 
VITALE, A M.; MONSERRAT, J. M.; CASTILHO, P.; RODRIGUEZ, E. M. Inhibitory effects of cadmium on carbonic anhydrase activity and ionic regulation of the estuarine crab Chasmagnathus granulata (Decapoda, Grapsidae). Comp Biochem Physiol Part C 122(1): 121-129, 1999.

VOSLOO, A.; VAN AARDT, W.J.; MIENIE, L.J. Sublethal effects of copper on the freshwater crab Potamonautes warreri. Comp Biochem Physiol Part A 133: 695-702, 2002.

WANG, W.X.; RAINBOW, P. S. Dietary uptake of $\mathrm{Cd}, \mathrm{Cr}$, and $\mathrm{Zn}$ by the barnacle Balanus trigonus : influence of diet composition. Mar Ecol Progr Ser 204: 159-168, 2000.

WANG, Z.; KONG, H.; WU, D. Acute and chronic copper toxicity to a saltwater cladoceran Moina monogolica Daday. Arch Environ Contam Toxicol 53(1): 50-56, 2007.

WEBB, M. (ed). Interactions of cadmium with cellular components. In: The chemistry, biochemistry and biology and cadmium. Amsterdan: Elsevier/North Holland Press, Amsterdan, pp.285-340, 1979.

WEBER, R.E. On the excretion of glucose in the lobster Jasus lalandii (Crustacea: Decapoda). Comp Biochem Physiol Part A 38: 465-467, 1971.

WEBSTER, S.G. Measurement of crustacean hyperglycaemic hormone levels in the edible crab Cancer pagurus during emersion stress. J Exp Biol 199: 1579-1585, 1996.

WEIHRAUCH, D.; MORRIS, S.; TOWLE, D. W. Ammonia excretion in aquatic and terrestrial crabs. J Exp Biol 207(26): 4491-504, 2004.

WHEATLY, M. G.; PENCE, R. C.; WEIL, J. R. ATP-dependent calcium uptake into basolateral vesicles from transporting epithelia of intermolt crayfish. Am J Physiol 276: R566-574, 1999.

WHEATLY, M. G.; ZANOTTO, F. P.; HUBBARD, M. G. Calcium homeostasis in crustaceans: subcellular Ca dynamics. Comp Biochem Physiol Part B 132(1): 163-178, 2002.

WOLMARANS, C.T.; YSSEL, E. Uptake and distribution of copper sulphate and its effect on the respiration rate of the hemocyanin - producing freshwater snail Lymnaea natalensis. Bull Environ Contam Toxicol 41: 214-221, 1988. 
WOOD, C. M. Flux measurements as indices of $\mathrm{H}^{+}$and metal effects on freshwater fish. Aquat Toxicol 22: 239-263, 1992.

WRIGHT, D. A. Trace Metal and Major Ion Interactions in Aquatic Animals. Science 31(95): 818, 1995.

WRIGHT, H.S.; GUTHRIE, H.A.; QI WANG, M.; BERNARDO, V. The 1987-1988 nationwide food consumption survey: an update on the nutrient intake of respondents. Nutr Today 26: 2127, 1991.

WU, J. P.; CHEN, H.C. Effects of cadmium and zinc on oxygen consumption, ammonium excretion, and osmoregulation of white shrimp (Litopenaeus vannamei). Chemosp 57(11): 1591-1598, 2004.

WU, J.P.; CHEN, H.C. Metallothionein induction and heavy metal accumulation in white shrimp Litopenaeus vannamei exposed to cadmium and zinc. Comp Biochem Physiol Part C 140(3-4): 383-394, 2005.

WU, J.P.; CHEN, H.C.; HUANG, D.J. Histopathological and biochemical evidence of hepatopancreatic toxicity caused by cadmium and zinc in the white shrimp, Litopenaeus vannamei. Chemosp 73(7): 1019-1026, 2008.

YAMAGUCHI, M. Regulatory effects of zinc and copper on the calcium transport system in rat liver nuclei: relation to SH groups in the releasing mechanism. Biochem Pharmacol 45(4): 943-948, 1993.

YANG, Z.B.; ZHAO, Y.L.; LI, N.; YANG, J. Effect of waterborne copper on the microstructures of gill and hepatopancreas in Eriocheir sinensis and its induction of metallothionein synthesis. Arch Environ Contam Toxicol 52(2): 222-228, 2007.

ZANOTTO, F. P.; WHEATLY, M. G. Calcium balance in crustaceans: nutritional aspects of physiological regulation. Comp Biochem Physiol Part A 133(3): 645-660, 2002.

ZANOTTO, F.P.; PINHEIRO, F.; BRITO, L.A.; WHEATLY, M.G. Some considerations on calcium homeostasis in semi-terrestrial crabs. Int Cong Ser 1275: 89-95, 2004. 
ZHANG, L.; WANG, W.X. Waterborne cadmium and zinc uptake in a euryhaline teleost Acanthopagrus schlegeli acclimated to different salinities. Aquat Toxicol 84(2): 173-181, 2007.

ZHUANG, Z.; AHEARN, G.A. Calcium transport processes of lobster hepatopancreatic brush border membrane vesicles. J Exp Biol 199: 1195-1208, 1996. 